\title{
Wildlife use and habitat quality of back channel areas associated with islands on the Ohio River, West Virginia
}

Andrew Karl Zadnik

West Virginia University

Follow this and additional works at: https://researchrepository.wvu.edu/etd

\section{Recommended Citation}

Zadnik, Andrew Karl, "Wildlife use and habitat quality of back channel areas associated with islands on the Ohio River, West Virginia" (2003). Graduate Theses, Dissertations, and Problem Reports. 1719.

https://researchrepository.wvu.edu/etd/1719

This Thesis is protected by copyright and/or related rights. It has been brought to you by the The Research Repository @ WVU with permission from the rights-holder(s). You are free to use this Thesis in any way that is permitted by the copyright and related rights legislation that applies to your use. For other uses you must obtain permission from the rights-holder(s) directly, unless additional rights are indicated by a Creative Commons license in the record and/ or on the work itself. This Thesis has been accepted for inclusion in WVU Graduate Theses, Dissertations, and Problem Reports collection by an authorized administrator of The Research Repository @ WVU. For more information, please contact researchrepository@mail.wvu.edu. 

Wildlife Use and Habitat Quality of Back Channel Areas
Associated with Islands on the Ohio River, West Virginia

\author{
Andrew Karl Zadnik \\ Thesis submitted to the \\ Davis College of Agriculture, Forestry, and Consumer Sciences \\ at West Virginia University \\ in partial fulfillment of the requirements \\ for the degree of \\ Master of Science \\ in \\ Wildlife and Fisheries Resource Management \\ James T. Anderson, Ph.D., Chair \\ Petra Bohall Wood, Ph.D. \\ Kerry Bledsoe
}

Morgantown, West Virginia

2003

Key Words: Riparian wildlife, waterbirds, anurans, turtles, furbearing mammals, habitat quality 


\section{ABSTRACT \\ Wildlife Use and Habitat Quality of Back Channel Areas \\ Associated with Islands \\ on the Ohio River, West Virginia}

\section{Andrew Karl Zadnik}

The islands and associated back channels on the Ohio River have long been thought to provide important habitat characteristics for riparian wildlife. However, few studies have quantitatively evaluated this importance. As pressure continues to develop back channels and, particularly, back channel mainland shorelines for commercial and residential use, quantitative information is vital for natural resource managers to justify conserving these areas for wildlife. The goals of my study were to quantify wildlife use of back and main channels relative to waterbirds, anurans, turtles, and riparian furbearing mammals, and to evaluate the habitat quality of back and main channels through the use of habitat suitability index (HSI) models. I found that wood duck (Aix sponsa) abundance (birds $/ \mathrm{km})$ was higher on back $(\bar{x}=1.73, \mathrm{SE}=0.25)$ than main $(\bar{x}=0.55$, $\mathrm{SE}=0.24)$ channels $(P<0.001)$. Belted kingfisher (Ceryle alcyon) abundance was higher on main $(\bar{x}=0.95, \mathrm{SE}=0.19)$ than back $(\bar{x}=0.35, \mathrm{SE}=0.08)$ channels $(P=0.001)$ during the summer. The 2 most abundant turtle species encountered also showed opposite trends in channel selection. Spiny softshells (Apalone spinifera) were more abundant (turtles/trap-night) on main $(\bar{x}=0.24, \mathrm{SE}=0.05)$ than back $(\bar{x}=0.01, \mathrm{SE}=0.01)$ channels $(P<0.001)$ during the summer. Conversely, total snapping turtle (Chelydra serpentina) abundance was higher on back $(\bar{x}=$ $0.17, \mathrm{SE}=0.03)$ than main $(\bar{x}=0.03, \mathrm{SE}=0.01)$ channels $(P<0.001)$. Anuran abundance (frequency of survey stations at which anurans were heard) was higher on back $(\bar{x}=0.54, \mathrm{SE}=$ $0.06)$ than main $(\bar{x}=0.17, \mathrm{SE}=0.05)$ channels $(P<0.001)$ during the first survey period. Beaver (Castor canadensis) abundance (frequency of sign and direct observations) was higher on back $(\bar{x}=0.8, \mathrm{SE}=0.04)$ than main $(\bar{x}=0.53, \mathrm{SE}=0.05)$ channels $(P<0.001)$. Muskrat (Ondatra zibethicus) also were more abundant on back $(\bar{x}=0.68, \mathrm{SE}=0.05)$ than main $(\bar{x}=$ $0.19, \mathrm{SE}=0.04)$ channels $(P<0.001)$. Based on HSI score, habitat quality was higher for wood duck brood-rearing on back $(\bar{x}=0.08, \mathrm{SE}=0.01)$ than main $(\bar{x}=0.02, \mathrm{SE}=0.00)$ channels $(P$ $<0.001)$. Similarly, muskrat habitat quality was higher on back $(\bar{x}=0.58, \mathrm{SE}=0.01)$ than main $(\bar{x}=0.54, \mathrm{SE}=0.01)$ channels $(P=0.004)$. Conversely, belted kingfisher habitat quality was higher on the main $(\bar{x}=0.42, \mathrm{SE}=0.01)$ than back $(\bar{x}=0.34, \mathrm{SE}=0.01)$ channels $(P<0.001)$. My results show that back channels are critical for riparian wildlife that require abundant woody cover and, likely, protection from the main current of the river and human disturbance. I suggest that back channel areas be conserved for wildlife and protected from high levels of human disturbance. 


\section{ACKNOWLEDGEMENTS}

I thank the following individuals for their assistance with the field and laboratory work for this project: Collins K. Balcombe, Timothy Guminey, Joseph D. Osbourne, Karen A. Sacilotto, Daniel Sole, Todd J. Polesiak, and Seth R. Lemley.

I thank George E. Seidel for his assistance and expertise with statistical analysis. A special thanks is extended to my committee members, in particular James T. Anderson and Petra Bohall Wood, for their knowledge, advice, and support. I thank the West Virginia Division of Natural Resources, which provided the majority of funds for my project, for the use of their boats and access to their research house. I thank the West Virginia Cooperative Fish and Wildlife Research Unit for administrative support and resources. I also thank the West Virginia University Davis College of Agriculture, Forestry, and Consumer Sciences (McIntire-Stennis Program) for funding and resources.

Finally, I thank my family for their support and guidance over the years, and I extend a special thanks to Allyson M. Patterson, for her never-ending love, support, and encouragement. 


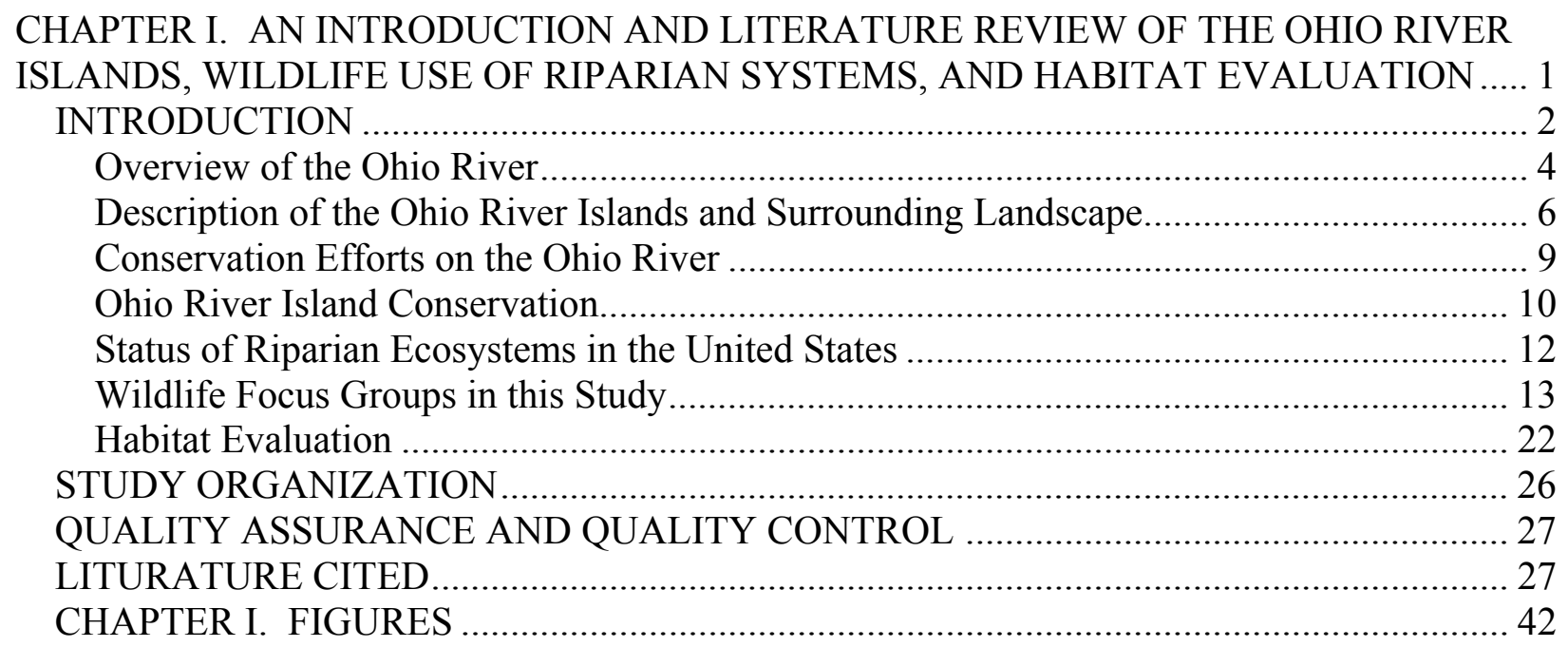

CHAPTER II. WILDLIFE USE OF BACK CHANNELS ASSOCIATED WITH ISLANDS ON

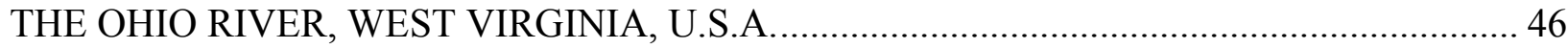

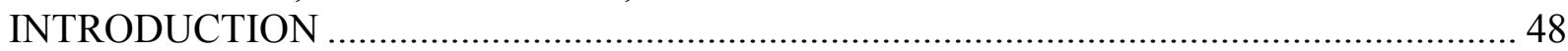

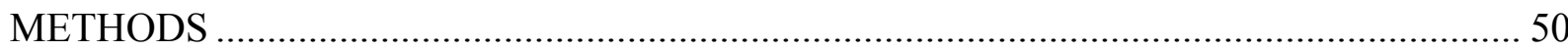

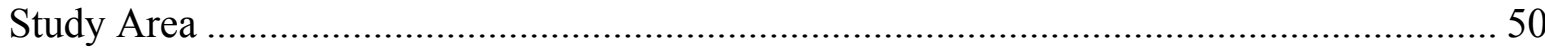

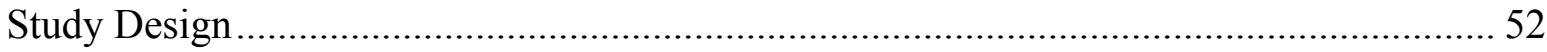

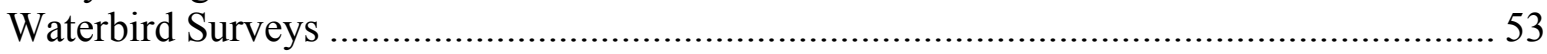

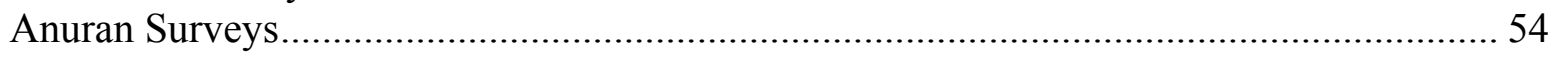

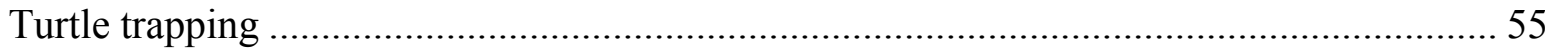

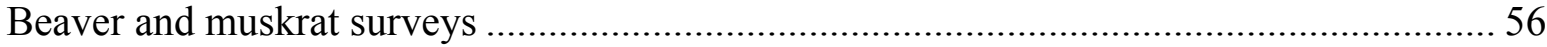

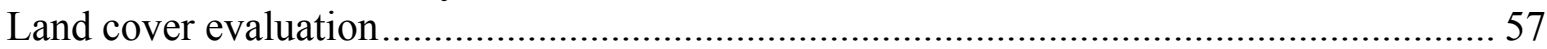

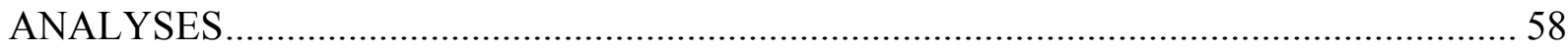

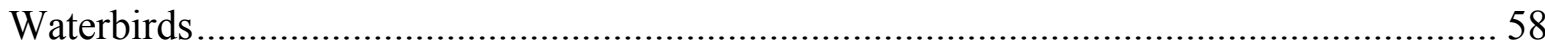

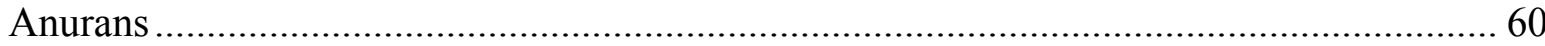

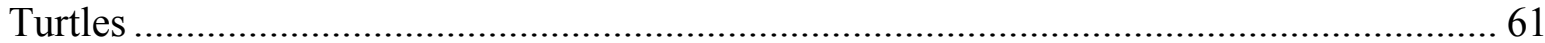

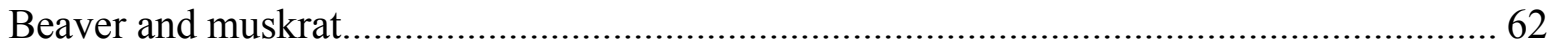

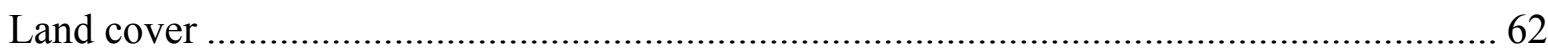

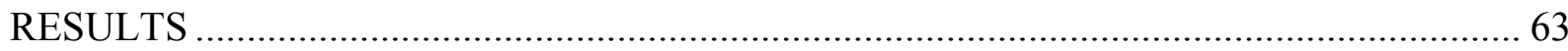

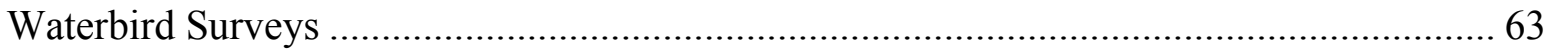

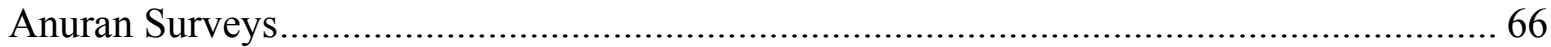

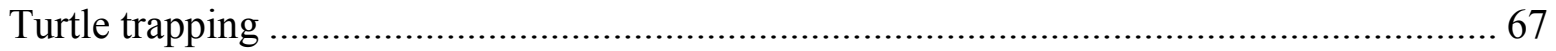

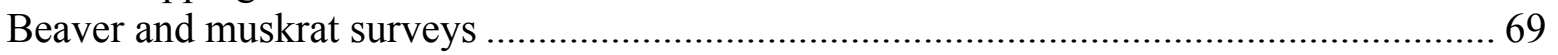

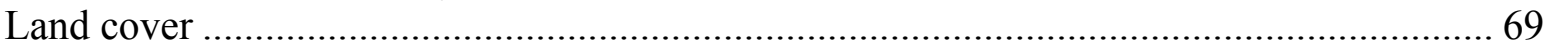

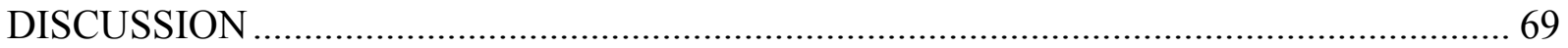

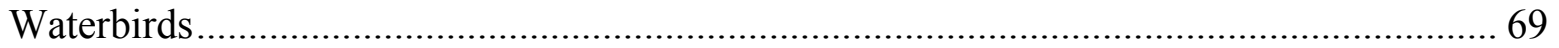

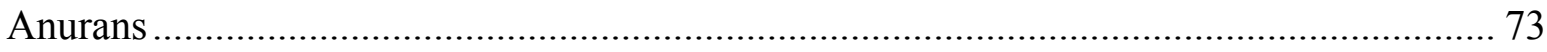

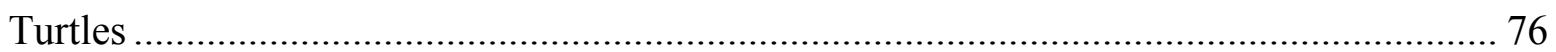

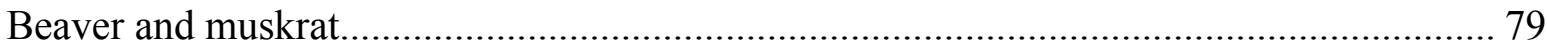

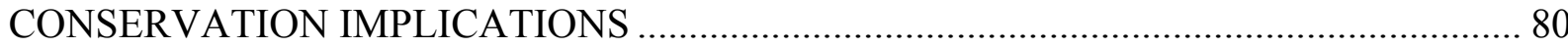

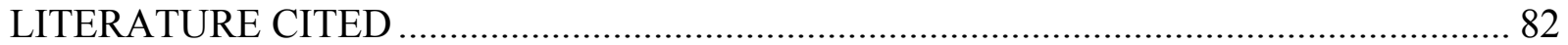




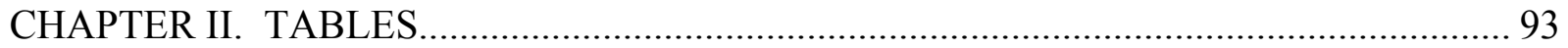

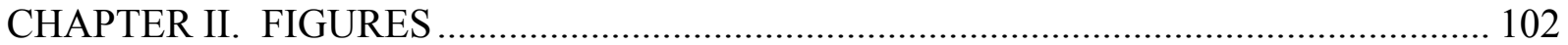

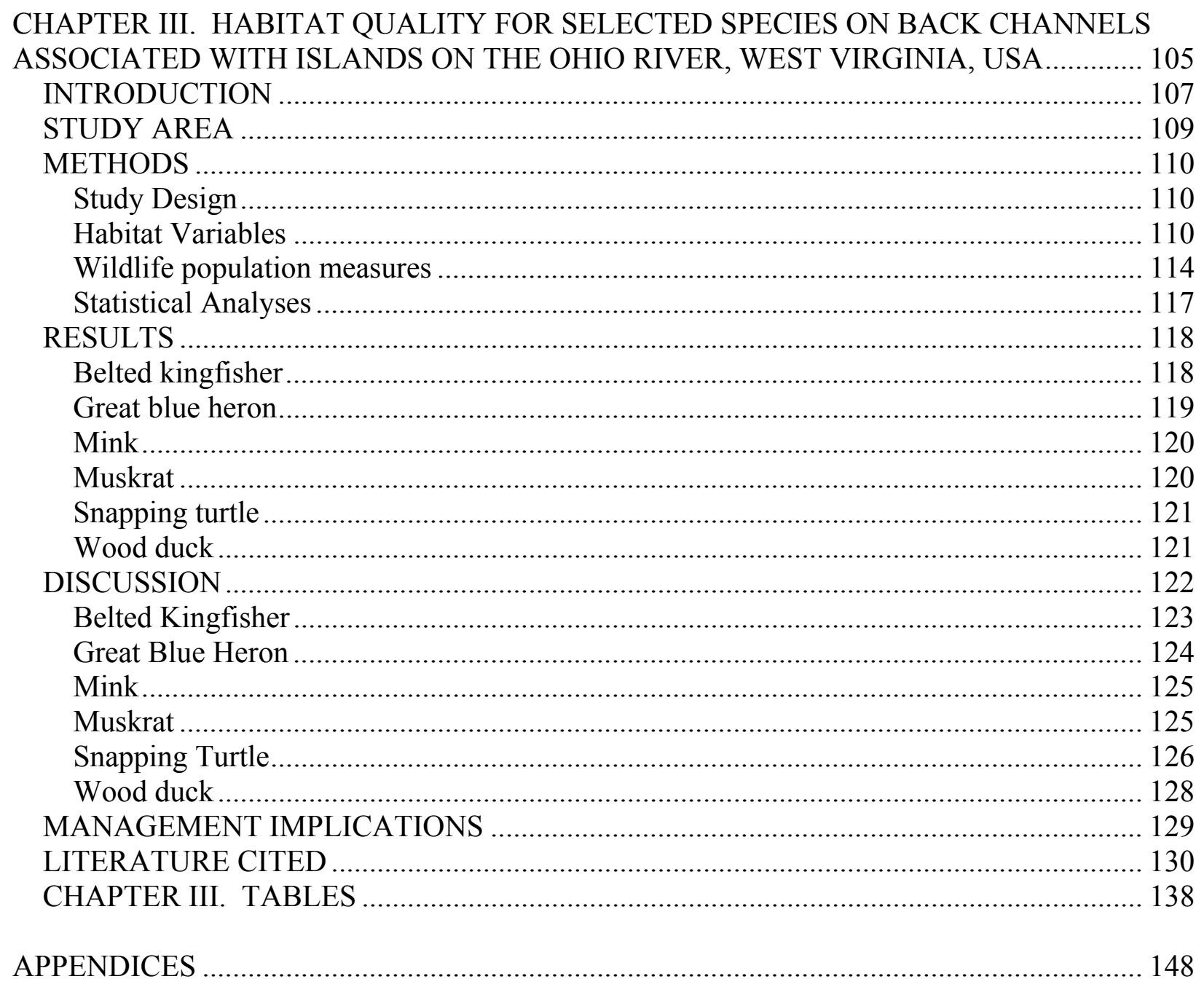




\section{CHAPTER I. LIST OF FIGURES}

Figure 1. The main channel (left) and back channel (right) associated with Paden Island

(center), Ohio River, West Virginia, 2001.

Figure 2. The main channel (left) and back channel (right) associated with Williamson Island (center), Ohio River, West Virginia, 2002.

Figure 3. The back channel associated with Captina Island (left), Ohio River, West Virginia, 2002

\section{CHAPTER II. LIST OF TABLES}

Table 1. Frequency (no. birds/km), species richness (no. species/channel) and diversity (Shannon \& Weaver 1949) of all waterbirds, and frequency of waterfowl, wading birds, and 5 waterbird species encountered on back and main channels, averaged by channel across years, associated with 10 islands on the Ohio River, West Virginia, USA, 2001-2002...... 94

Table 2. Frequency (no. birds/km), species richness (no. species/treatment) and diversity (Shannon \& Weaver 1949) of all waterbirds, and frequency of waterfowl, wading birds and 5 waterbird species encountered in 4 treatments $(\mathrm{BI}=$ back channel-island side, $\mathrm{BM}=$ back channel-mainland side, $\mathrm{MI}=$ main channel-island side, $\mathrm{MM}=$ main channel-mainland side), averaged by treatment across years, associated with 10 islands on the Ohio River, West Virginia, USA, 2001-2002..

Table 3. Relative abundance of anurans encountered on back and main channels, averaged by channel across years, associated with 10 islands on the Ohio River, West Virginia, USA, 2001-2002.

Table 4. Distribution (\%) of call index values (CIV; Mossman 1994) for 3 anuran species encountered on back and main channels, averaged by channel across years, associated with 10 islands on the Ohio River, West Virginia, USA, 2001-2002.

Table 5. Relative abundance (no. captured/trap-night) of all turtles, snapping turtles and spiny softshells encountered on back and main channels associated with 10 islands on the Ohio River, West Virginia, USA, 2001-2002.

Table 6. Relative abundance (no. captured/trap-night) of all turtles, snapping turtles and spiny softshells encountered in 4 treatments $(\mathrm{BI}=$ back channel-island side, $\mathrm{BM}=$ back channelmainland side, $\mathrm{MI}=$ main channel-island side, $\mathrm{MM}=$ main channel-mainland side), associated with 10 islands on the Ohio River, West Virginia, USA, 2001-2002. 100

Table 7. Percent (\%) land cover types on back channel-mainland side (BM) and main channel- 
mainland side (MM) treatment shorelines, within $300 \mathrm{~m}$ of the water's edge, associated with 10 islands on the Ohio River, West Virginia, USA (U. S. Geological Survey 2002). 101

\section{CHAPTER II. LIST OF FIGURES}

Figure 1. Location of 10 islands (names in black type), between river kilometer 174 and 349, on the Ohio River, West Virginia, USA.

Figure 2. An island (Buffington) on the Ohio River, West Virginia, USA (the state of Ohio is on the left [west] bank), illustrating 4 treatments (BM: back channel-mainland side; BI: back channel-island side; MI: main channel-island side; MM: main channel-mainland side). Each treatment encompasses the length of the associated island and one-half of the width of the associated back channel.

\section{CHAPTER III. LIST OF TABLES}

Table 1. Variables (V) measured and equations used to determine life components (based on variable suitability indices [SI]), and habitat suitability index (HSI) scores for belted kingfisher, great blue heron, mink, muskrat, snapping turtle, and wood duck, on the Ohio River, West Virginia, 2001-2002. .

Table 2. Habitat suitability index (HSI) model scores, and the scores of model components, for 6 species, on back and main channels, and island and mainland sides, associated with 10 islands on the Ohio River, West Virginia, USA, 2001-2002. ${ }^{\mathrm{a}}$

Table 3. Habitat suitability index (HSI) model scores, and the scores of model components, for 6 species on 4 treatments, associated with 10 islands on the Ohio River, West Virginia, USA, 2001-2002. ${ }^{\mathrm{a}}$

Table 4. Relative abundance of 5 species on back and main channels, and island and mainland sides, averaged by channel and side across years, associated with 10 islands on the Ohio River, West Virginia, USA, 2001-2002. .

Table 5. Relative abundance of 5 species on 4 treatments associated with 10 islands on the Ohio River, averaged by treatment across years, West Virginia, USA, 2001-2002. ….

Table 6. Linear regression models of relative abundance of 5 species modeled with habitat suitability index (HSI) models and model components in areas associated with 10 islands on the Ohio River, West Virginia, 2001-2002. ${ }^{\mathrm{a}}$

Table 7. Backwards selection multiple regression models of relative abundance of 5 species modeled with habitat suitability index (HSI) model variables in areas associated with 10 
islands on the Ohio River, West Virginia, 2001-2002. ${ }^{\mathrm{a}}$

\section{LIST OF APPENDICES}

Appendix A. Island area (ha), area and length $(\mathrm{km})$ of 4 treatments $^{\mathrm{a}}$, and width $(\mathrm{km})$ of back (BC) and main (MC) channels $\mathrm{s}^{\mathrm{b}}$, associated with 10 islands on the Ohio River, West Virginia, USA.

Appendix B. Land cover types within $300 \mathrm{~m}$ of the water's edge along the back channel and main channel mainland shorelines, based on a 1:100,000 scale, associated with 10 islands on the Ohio River, West Virginia, USA (U. S. Geological Survey 2002).

Appendix C. Density (no. birds/ha), frequency (no. birds $/ \mathrm{km}$ ), species richness (no. species/treatment) and diversity (Shannon \& Weaver 1949) of all waterbirds, and density and frequency of waterfowl, wading birds and 5 waterbird species encountered on island and mainland sides, averaged by side across years, associated with 10 islands on the Ohio River, West Virginia, USA, 2001-2002.

Appendix D. Density (no. birds/ha) of all waterbirds, waterfowl, wading birds, and 5 waterbird species encountered on back and main channels, averaged by channel across years, associated with 10 islands on the Ohio River, West Virginia, USA, 2001-2002.

Appendix E. Density (no. birds/ha) of all waterbirds, waterfowl, wading birds, and 5 waterbird species encountered in 4 treatments $(\mathrm{BI}=$ back channel-island side, $\mathrm{BM}=$ back channelmainland side, $\mathrm{MI}=$ main channel-island side, $\mathrm{MM}=$ main channel-mainland side), averaged by treatment across years, associated with 10 islands on the Ohio River, West Virginia, USA, 2001-2002.

Appendix F. Frequency (no. birds/km), species richness (no. species/channel) and diversity (Shannon \& Weaver 1949) of all waterbirds, and frequency of waterfowl and wading birds encountered on back and main channels, including those occurring farther from the main channel shorelines than half the width of the associated back channel, averaged by channel across years, associated with 10 islands on the Ohio River, West Virginia, USA, 2001-2002.

Appendix G. Density (no. broods/ha) and frequency (no. broods $/ \mathrm{km}$ ) of wood duck broods encountered on island and mainland sides, averaged by side across years, associated with islands on the Ohio River, West Virginia, USA, 2001-2002.

Appendix H. Density (no. birds/ha) and frequency (no. birds/km) of all waterbird species encountered in 4 treatments $(\mathrm{BI}=$ back channel-island side, $\mathrm{BM}=$ back channel-mainland side, $\mathrm{MI}=$ main channel-island side, $\mathrm{MM}=$ main channel-mainland side), averaged by treatment across years, associated with 10 islands on the Ohio River, West Virginia, USA, 2001-2002. 
Appendix I. Density (no. birds/ha) and frequency (no. birds $/ \mathrm{km}$ ) of all waterbird species encountered on back and main channels, and island and mainland sides, averaged by channel and side across years, associated with 10 islands on the Ohio River, West Virginia, USA, 2001-2002.

Appendix J. Relative abundance (no. captured/trap-night) of all turtles, snapping turtles and spiny softshells encountered on island and mainland sides associated with 10 islands on the Ohio River, West Virginia, USA, 2001-2002.

Appendix K. Relative abundance (frequency of transects containing sign or direct observations) of beavers and muskrat encountered on island and mainland sides associated with 10 islands on the Ohio River, West Virginia, USA, 2001-2002. 189

Appendix L. Tests for channel, side, and treatment interactions with year, season, and/or period for measures of relative abundance of waterbirds, waterfowl, wading birds, 5 waterbird species, turtles, 2 turtle species, and waterbird richness (no. species) and diversity (Shannon \& Weaver 1949), associated with 10 islands on the Ohio River, West Virginia, USA, 20012002. ${ }^{\mathrm{a}}$

Appendix M. Tests for channel interactions with year, season, and/or period for frequency (no. birds $/ \mathrm{km}$ ) of waterbirds, waterfowl, and wading birds, waterbird richness (no. species/channel) and waterbird diversity (Shannon \& Weaver 1949), including those individuals occurring farther from main channel shorelines than half the width of the associated back channel, associated with 10 islands on the Ohio River, West Virginia, USA, 2001-2002. ${ }^{\mathrm{a}}$

Appendix N. Variables (V) measured and equations used to determine life components (based on suitability indices [SI]), and habitat suitability index (HSI) scores for belted kingfisher (Prose 1985), great blue heron (Short and Cooper 1985), mink (Allen 1984), muskrat (Allen and Hoffman 1984), snapping turtle (Graves and Anderson 1987), and wood duck (Sousa and Farmer 1983) models, on treatments, channels, and sides, associated with 10 islands on the Ohio River, West Virginia, 2001-2002. ${ }^{\text {a }}$

Appendix O. Tests for channel, side, and treatment interactions with year, season, and/or period for measures of relative abundance of belted kingfishers, great blue herons, snapping turtles, and wood ducks, measured in accordance with habitat suitability index models, associated with 10 islands on the Ohio River, West Virginia, USA, 2001-2002. ${ }^{\mathrm{a}}$ 202 


\title{
CHAPTER I
}

\section{AN INTRODUCTION AND LITERATURE REVIEW OF THE OHIO RIVER ISLANDS, WILDLIFE USE OF RIPARIAN SYSTEMS, AND HABITAT EVALUATION}

\author{
ANDREW K. ZADNIK \\ azadnik@hotmail.com \\ West Virginia University \\ Division of Forestry \\ P. O. Box 6125 \\ Morgantown, WV 26506-6125
}




\begin{abstract}
The Ohio River islands have been dramatically altered over the past 200 years due to industrialization and navigational projects. The islands and associated back channels are believed to support an abundance of wildlife due to the interspersion of wetland and upland cover types. Wildlife that particularly benefit from these areas include waterbirds, anurans, turtles, and riparian furbearing mammals. Many of the islands are protected from further exploitation due to being incorporated into a national wildlife refuge. However, there is continued pressure to develop the back channels and back channel mainland shorelines. Quantitative information on the use of these areas by wildlife and an evaluation of habitat characteristics are needed to justify conservation measures. My objectives with this study were to provide this information.
\end{abstract}

\title{
Wildlife Society Bulletin 00(0):000-000
}

Key words: Ohio River, island back channel, riparian wildlife, habitat suitability, West Virginia.

\section{INTRODUCTION}

Human development and use of the Ohio River has been a common theme throughout modern history. Native Americans traveled along the river long before Europeans arrived on this continent (U. S. Water Resources Council 1971). As the United States was forming, the Ohio River became a major route of travel to the western territories. To improve the river for navigation, snag pulling and the dredging of sandbars were both regularly employed (Frost and Mitsch 1989). Locks and dams also were built to maintain a navigable channel. These activities

This chapter is in the style of the Wildlife Society Bulletin 
essentially changed the Ohio from a free-flowing river to a series of connected lakes (Frost and Mitsch 1989).

The islands on the Ohio River have not escaped the effects of this development. In the early 1900s, 14 of the 49 islands located within the West Virginia portion of the river were eliminated (1 was actually created) due to industrialization and navigational projects (Tolin and Schettig 1983). In general, islands all along the Ohio River have decreased by 43\% since 1900 (U. S. Army Corps of Engineers [USACE] 2000). Current activities viewed as potential threats to the islands, back channels, and back channel shorelines include commercial sand and gravel dredging, industrial development, gas/oil wells, logging, mooring activities, and to an extent, recreational activities and residential development (Tolin and Schettig 1983; U. S. Fish and Wildlife Service [USFWS] 1989, 2002).

It is generally believed that the Ohio River islands and associated back channels are important for wildlife (USFWS 2002). However, quantitative data are lacking on wildlife use of these areas, particularly the back channels. Hesse (1996) noted that the habitat value for wildlife associated with river islands has been underrated. In fact, there is a lack of basic knowledge regarding wildlife inhabiting large river systems in general (Johnson et al. 1995). Tolin and Schettig (1983) provided one of the first qualitative reports specifically addressing the fish and wildlife resources of the Ohio River islands and surrounding areas. They noted that early studies by the USACE on Ohio River dredging operations deliberately ignored the islands (Tolin and Schettig 1983). Nevertheless, the USACE recently acknowledged the need to restore and protect 40 of the islands, as well as restore bottomland hardwood forests and other wetland and aquatic areas (USACE 2000).

Today, many islands on the Ohio River are essentially protected from direct commercial 
exploitation due, in part, to the creation of a national wildlife refuge. However, most of the associated back channels and back channel mainland shorelines remain under pressure to be developed (USFWS 2000). As the agency responsible for managing fish and wildlife resources on the Ohio River, and for reviewing permit applications for development activities, the West Virginia Division of Natural Resources (WVDNR) needs quantitative information on the ecological value of island back channels. This information will help determine what, if any, types of activities are compatible with conserving these areas as important riparian wildlife habitat. The specific objectives of my study were to:

1) quantify species diversity, richness, and relative abundance of waterbirds, anurans, and turtles, and relative abundance of American beavers (Castor canadensis; hereafter beaver) and common muskrat (Ondatra zibethicus; hereafter muskrat) on back channel and main channel areas associated with islands on the Ohio River; and

2) evaluate relative habitat characteristics between back channel and main channel areas using Habitat Suitability Index models for the wood duck (Aix sponsa), belted kingfisher (Ceryle alcyon), muskrat, American mink (Mustela vison; hereafter mink), great blue heron (Ardea herodias), and snapping turtle (Chelydra serpentina).

\section{Overview of the Ohio River}

The Ohio River Basin drains an area of approximately 365,190 square kilometers and includes portions of Illinois, Indiana, Kentucky, Maryland, New York, Ohio, Pennsylvania, Tennessee, Virginia, and West Virginia (USFWS 1999). The Ohio River begins at the confluence of the Monongahela and Allegheny Rivers at Pittsburgh, Pennsylvania, and flows 1,579 $\mathrm{km}$ southwest and west where it joins the Mississippi River near Cairo, Illinois (USFWS 
1999). The river averages $405 \mathrm{~m}$ wide with an average gradient of $0.10 \mathrm{~m}$ per $\mathrm{km}$ (USACE 1981). Many of the islands in the West Virginia portion of the Ohio River are in the vicinity of Parkersburg, West Virginia and Marietta, Ohio, an area with a human population $>150,000$ (U. S. Census Bureau 2003).

Water quality in the Ohio River generally ranges from acceptable to good. The water's $\mathrm{pH}$ is nearly neutral, with adequate dissolved oxygen and relatively low iron and manganese concentrations. However, poor land management practices in the watershed (e.g., mining, logging, agriculture) lead to extensive periods of turbidity, which impact water quality and wildlife (USFWS 2002).

European exploration of the Ohio River began in the late $17^{\text {th }}$ Century (USACE 1998). The English claimed much of the Ohio River territory by a purchase from Native Americans in 1744. With the English victory in the French and Indian War (1756-1763), English settlement of the region greatly accelerated (USACE 1998). European settlers originally depended on the flatboat and keelboat for transportation on the river, both powered by oar, pole, or sail. The first steamboat was launched at Pittsburgh in 1811 (Cramer 1814: 31). Steps to improve the river for navigation began in 1824 when Congress authorized the removal of snags and sandbars by the USACE. The first federally built lock and dam on the Ohio River was completed near Pittsburgh in 1885 (USACE 1998).

Today, a system of 20 locks and dams provide for year-round navigation (USACE 2000). Additionally, annual dredging maintains the main channel at a depth $\geq 2.7 \mathrm{~m}$ (USACE 2002a). The primary commodities transported on the river are coal, sand, gravel, and petroleum products (USACE 2002a). Approximately 240 million $\mathrm{t}$ of bulk commodities were shipped on the Ohio River in the late 1990s (USACE 2000). 


\section{Description of the Ohio River Islands and Surrounding Landscape}

The Ohio River is primarily located within the Appalachian Plateau Physiographic Province (USFWS 2002). The islands on the river were formed by the accumulation of sand and gravel outwash during periods of extreme glacial melt (Reid 1961, USFWS 2002). This initial accumulation and subsequent actions of the river have led to the islands being generally teardrop or crescent shaped, with round, shallow heads, and narrow, pointed toes. The shallow fronts consist of gravel and cobbles that, on many of the islands, have been severely degraded due to dredging operations (Tolin and Schettig 1983). The sides of the islands typically drop off to form deep pockets. The toes slope off gradually for some distance (Tolin and Schettig 1983). The aquatic substrates consist of muck, detritus, silt, clay, sand, gravel, cobble, riprap, emergent and submergent stumps and logs, and emergent and submergent aquatic beds (Tolin and Schettig 1983). The island and floodplain soils are primarily fine sandy or silt loams of the Huntington, Chagrin, and Linside series. These soils range from very well drained to somewhat poorly drained (U. S. Department of Agriculture 1960, 1961, 1970, 1989, 1995). Islands that formed off to one side of the river resulted in the creation of back channels (i.e., channels between the island and mainland not exposed to the main thalweg of the river and not receiving commercial barge traffic; Figures 1-3). Since there is no longer any glacial outwash and due to the current navigation system, new islands will not be created (USFWS 2002).

The wetland areas associated with the islands and back channels of the Ohio River are characterized as riverine and palustrine (Cowardin et al. 1979). Palustrine areas generally are wetlands dominated by trees, shrubs, and persistent emergent vegetation. These areas also are known as marshes, swamps, or bogs (Cowardin et al. 1979). The palustrine areas in this study 
include palustrine unconsolidated bottom, palustrine emergent, palustrine scrub-shrub, and palustrine forested (Tolin and Schettig 1983). Riverine areas include all wetlands and aquatic areas contained within a channel that are not dominated by trees, shrubs, and persistent emergent vegetation. This study area consists of riverine aquatic bed, riverine emergent, riverine rock bottom, and riverine unconsolidated bottom (Cowardin et al. 1979, Tolin and Schettig 1983). Aquatic plant species found in these types include water willow (Decodon verticillatus), arrowhead (Sagittaria spp.), yellow iris (Iris pseudacorus), pondweeds (Potamogeton spp.), and duckweeds (Lemna spp.). The Ohio River itself is classified as riverine lower perennial modified by impoundments (Cowardin et al. 1979). Low gradient and slow water velocity characterize this type, as well as lack of any tidal influence. Whereas palustrine emergent areas can consist of persistent as well as nonpersistent vegetation, the vegetation in riverine emergent areas is entirely nonpersistent (Cowardin et al. 1979). These areas can be grouped together under the heading of a riparian ecosystem (Brinson et al. 1981).

The terrestrial cover types in this area consist of various seral stages of bottomland hardwood forest. Due to human development along the river, much of this type has been eliminated, with only narrow strips ( $<90 \mathrm{~m})$ remaining in many areas (USFWS 2002). Dominant tree species in the forest overstory are silver maple (Acer saccharinum), sycamore (Populus occidentalis), cottonwood (Populus deltoides), and black willow (Salix nigra). Understory trees include common hackberry (Celtis occidentalis), black locust (Robinia pseudoacacia), green ash (Fraxinus pennsylvanica), box elder (A. negundo), pawpaw (Asimina triloba), and black walnut (Juglans nigra). Shrubs include spicebush (Lindera benzoin), Virginia creeper (Parthenocissus quinquefolia), poison ivy (Toxicodendron radicans), dogwoods (Cornus spp.), and grapes (Vitis spp.). Herbaceous plants include touch-me-not (Impatiens capensis), wingstem (Verbesina 
alternifolia), white snakeroot (Ageratina altissima), and exotic invasive species such as Japanese knotweed (Polygonum cuspidatum), mile-a-minute vine (Ipomoea cairica), and kudzu (Pueraria montana; USFWS 2002).

The oldfield successional stage of this cover type was created by past agricultural practices, oil and gas activities, recreational development, logging, and industrial activities. The vegetation in these areas consists of various herbaceous species and grasses, with some woody species becoming dominant (USFWS 2002).

The interspersion of cover types on and around the Ohio River islands support an abundance of fish and wildlife species (USFWS 2002). Over 200 species of birds have been identified, including 78 that breed there. The number of mammal species that inhabit the area is somewhat affected by the flooding regime and has been documented at 25 . The most common mammals include white-tailed deer (Odocoileus virginianus), red foxes (Vulpes vulpes), raccoons (Procyon lotor), muskrat, and fox squirrels (Sciurus niger). Similarly, the herpetofaunal community is primarily made up of the more aquatic types (excluding most snakes and salamanders) and includes at least 15 species. Herpetofauna identified on and around the islands include American toads (Bufo americanus), Fowler's toads (B. fowleri), American bullfrogs (Rana catesbeiana), spring peepers (Pseudacris crucifer), eastern box turtles (Terrapene carolina), snapping turtles (Chelydra serpentina), painted turtles (Chrysemys picta), and spiny softshells (Apalone spinifera; USFWS 2002). Thirty-eight mussel species have been identified around the islands in the upper Ohio River. Mussels in particular have been adversely impacted by water quality, habitat degradation and, most recently, by invasion of zebra mussels (Dreissena polymorpha). Though difficult to thoroughly sample, over 100 species of warm water fishes have been identified. Four federally listed species occur in the area: bald eagle 
(Haliaeetus leucocephalus), Indiana bat (Myotis sodalis), pink mucket pearly mussel (Lampsilis orbiculata), and fanshell mussel (Cyprogenia stegaria; USFWS 2002).

\section{Conservation Efforts on the Ohio River}

In 1998, the USACE began the Ohio River Mainstem Systems Study (Steiner 2000). This study was originally designed to examine future navigational needs for the river, including any foreseeable maintenance, rehabilitation, or future construction projects. Included in this study was the formation of an environmental team, consisting of personnel from the USACE, USFWS, and the natural resource agencies of 6 states (Steiner 2000).

During the initial study process, natural resource agencies of states bordering the river proposed over 250 site-specific environmental projects for further analysis. This finding necessitated the need for a separate ecosystem restoration program. Thus, as an amendment to the Mainstem Systems Study, the Ohio River Ecosystem Restoration Program was proposed (Steiner 2000). The primary purpose of the program is to "restore significant ecosystem function, structure, and dynamic processes that have been degraded" (USACE 2000b). The Water Resources Development Act of 2000 officially authorized the project, though, as of 2002, funding had yet to be appropriated (USACE 2000b).

Another program aimed at improving the natural systems of the Ohio River is the Ohio River Ecosystem Team, started by the USFWS in 1999 (USFWS 1999). The broad goals of this group are to protect, restore and enhance species diversity, promote and support compatible and sustainable uses of ecosystems, and develop public awareness and support for conserving natural resources (USFWS 1999). Some of the resource priorities this team is focusing on include native aquatic mollusks, migratory land birds, native fishes, karst/cave habitat, wetland, riverine and 
riparian habitat, declining and rare species, and fish and wildlife-oriented recreation (USFWS 1999).

\section{Ohio River Island Conservation}

Despite past human activities on and around the islands, many of the islands have remained generally undeveloped, probably due to their isolation (USFWS 1989). In fact, the islands and associated areas contain near complete assemblages of species endemic to the river (Tolin and Schettig 1983). State and federal authorities have long recognized the importance of these islands and the associated back channels to wildlife (Tolin and Schettig 1983, USFWS 1989). The USFWS classified these areas as Resource Category 1, meaning they are unique and irreplaceable (USFWS 1989). A 1979 report prepared by the USFWS described the biological and recreational importance of 18 islands in the upper part of the river. The report concluded with the recommendation that these areas be protected from commercial development and maintained in their natural state (Tolin and Schettig 1983). Tolin and Schettig's (1983) report and subsequent letters from the USFWS and WVDNR expressed concerns about the exploitation of these areas and the continued pressure placed on them (USFWS 1989).

A 1989 Environmental Assessment discussed the intent of the USFWS to secure protection of the islands by incorporating them into a national wildlife refuge. This refuge would serve to preserve the biodiversity and abundance of wildlife on the islands and provide educational and recreational opportunities for the public to enjoy the natural resources (USFWS 1989). Several alternatives for protection were discussed in the report. One alternative was to have protection solely depend on existing laws and regulations. The USFWS anticipated that this alternative would result in the continued degradation of the islands and surrounding areas. 
The second alternative was the proposed action. This would entail purchasing all or a portion of 38 islands in the river. The USFWS estimated that this action would protect about 1,417 ha of bottomland, wetland, and riverine habitat. Any activities thought to be detrimental to the USFWS's intent of protecting these areas would be controlled or eliminated on the refuge. A third alternative would consist of purchasing a "core" group of 22 islands that are essentially undisturbed and in close proximity to each other. The consequences of this alternative would be similar to those under the second one, only it would apply to about $80 \%$ of the desired area of the refuge. The final alternative discussed the idea of other public and private natural resource agencies purchasing the islands. The USFWS anticipated that this would adequately protect the desired areas; however eventually ownership would be transferred to the USFWS (USFWS 1989).

The second alternative was the one taken by the USFWS. The Ohio River Islands National Wildlife Refuge was formally established in 1990 with the purchase of 8 islands. In 2000, the refuge consisted of 20 islands, a portion of 1 additional island, and 3 mainland tracts, all encompassing about 1,304 ha of terrestrial and aquatic areas (USFWS 2000). The majority of back channel mainland shoreline areas remain under private ownership, however, and are faced with the potential for development.

The WVDNR is the agency responsible for managing fish and wildlife resources, and for reviewing permit applications for development activities, on the West Virginia portion of the Ohio River. Despite qualitative evidence regarding the value of island back channels for wildlife, it has become increasingly difficult for the agency to justify conserving these areas. Quantitative information is needed by the WVDNR to use when reviewing permit applications for activities that may further degrade back channel areas. Furthermore, this information will aid 
resource managers in developing plans for the long-term conservation of these areas and the enhancement of critical habitat characteristics.

\section{Status of Riparian Ecosystems in the United States}

Riparian ecosystems have declined by at least $70 \%$ in the United States. In 1981, they occupied 10-15 million ha in the contiguous United States. This was less than $2 \%$ of the total land area (Brinson et al. 1981). Alterations to these areas have been mostly due to the demand for water and agricultural land (Brinson et al. 1981). Mississippi bottomland hardwood forests declined in area by approximately $77 \%$ from pre-European settlement-1992 (The Nature Conservancy 1992). Bottomland forests in southeastern Missouri declined from 1.0 million ha in 1780 to 40,000 ha in 1975 (Korte and Fredrickson 1977). By 1989, only about 14\% of the total upper Mississippi River floodplain was forested (Laustrup and Lowenberg 1994). Along the Ohio River, 65\% of the forested floodplain was lost between 1800 and 1970 (USACE 2000b). Exact losses of riparian ecosystems due to channel alteration and other water projects have not been determined, but they are known to be extensive. Construction of impoundments has particularly been destructive (Brinson et al. 1981). From 1970 to 1980, the total amount of land inundated by reservoirs increased by 409,550 ha to a total of 3,989,000 ha (Ploskey and Jenkins 1980). The land area covered by large reservoirs alone has been estimated to be $8 \%$ of the total 100-year floodplain area (Brinson et al. 1981).

In an undisturbed state, riparian ecosystems provide abundant food, water, and cover for a high diversity of species. Up to $70 \%$ of all vertebrates in a region will use riparian ecosystems in a significant way at some point during their life cycle (Raedeke 1989). The biological and physical features that make up a natural riparian ecosystem support more species than any other 
terrestrial system (Brinson et al. 1981, Naiman et al. 1993). Some of these features include a structurally complex area of vegetation, the presence of surface water and soil moisture, a heterogeneous interspersion between cover types, and a protected corridor to allow for movements between areas.

\section{Wildlife Focus Groups in this Study}

Results of the few quantitative studies that have been completed on and around the Ohio River islands are inconsistent regarding the value of these areas for certain taxa. Thorp (1992) found an increase in density and diversity of invertebrates related to the heterogeneity of island characteristics. He noted that the islands likely enhance snag formation and the input of organic matter, which have positive effects on macroinvertebrates. Zeto et al. (1987) found a high abundance and diversity of mussels inhabiting areas around islands in 2 navigational pools. Conversely, Millard (1993) found that several fish species appeared to avoid the back channel areas of 2 islands. He noted that turbidity along the shorelines during periods of wind or high flow could lower the quality of back channels as spawning and nursery habitat. Sacilotto (2002) found a lower abundance of birds on back channel compared to main channel sides in 2000 , although abundance was similar between sides in 2001. In addition, bird diversity was similar between sides in 2000, although the back channel side had higher bird diversity than the main channel side in 2001.

Four groups of wildlife that are particularly dependent on healthy riparian ecosystems are waterbirds, anurans, turtles, and riparian furbearing mammals (Semlitsch 2000). Quantitative information on the use of Ohio River islands and back channels by these groups is lacking. Waterbird data appear to be limited to overall great blue heron productivity and wood duck 
nestbox use (USFWS 2002, K. A. Sacilotto, personal communication). However, on the Missouri River, back channels were found to provide important feeding, loafing, and breeding areas for waterbirds (Funk and Robinson 1974). Riparian furbearers also were found to use those areas on the Missouri. On the Ohio River, riparian furbearers are considered to be more abundant on back channels than the main channel (USFWS 2002). However, information regarding this group is entirely qualitative and likely based on incidental observations by refuge staff (USFWS 2002). Anurans and turtles particularly have not been well studied on the Ohio River, with only county presence or absence data available (USFWS 2002). For these reasons, I chose to focus my study on these groups.

Waterbirds.--This group includes waterfowl, seabirds, shorebirds, wading birds and belted kingfishers (Weller 1999). Studies of waterbirds in riparian areas specifically are few. However, generalizations can be made regarding those habitat factors governing the use of other wetlands by this group and applied to riparian areas. One important factor is the interspersion between areas of emergent vegetation and open water. Studies have found that more species are found where there is a vegetation/open water ratio of 1:1 (Weller and Spatcher 1956, Weller 1981). Weller (1981) found that species richness was highest in areas with 50-75\% open water. This is especially true with wading birds, such as herons and rails, which are known to forage in openings among emergent vegetation (Thompson 1979, Conway 1995, Melvin and Gibbs 1996). Edwards et al. (1999) noted that the highest abundance of wading birds was found within a wide, flat floodplain with a stable shoreline for foraging. Other species, such as terns and belted kingfishers, are known to feed over open water and use emergent stumps and logs as perches (Weller 1999).

Nesting waterbirds on and around the Ohio River islands include great blue herons, 
green herons (Butorides virescens), mallards (Anas platyrhynchos), Canada geese (Branta canadensis), and killdeer (Charadrius vociferus; USFWS 2002). However, the most abundant nesting species is the wood duck (Tolin and Schettig 1983). Wood ducks are highly dependent on riparian ecosystems for all their habitat requirements (Hesse 1996). Use of these areas is dependent on wooded shorelines, fallen trees, and aquatic vegetation (McGilvrey 1968, Hocutt and Dimmick 1971, Smith and Flake 1985, Cottrell et al. 1990). Cottrell et al. (1990) found that cover type selection by females with broods indicated a preference for aquatic bed zones and emergent wetlands over open water areas. Preferred shoreline cover types were grazed and ungrazed lowland hardwoods, nonforested herbaceous, and scrub/shrub (Cottrell et al. 1990).

Kaminski et al. (1993) found that wood duck winter habitat in bottomland hardwood forests featured more understory cover as compared with mallard habitat. Other species depend on similar characteristics. For instance, American woodcock (Scolopax minor) habitat preference in bottomland hardwood forests is known to include dense woody midstories, sparse ground cover, and moist soil containing abundant earthworms (Evans and Wilson 1982, Rabe et al. 1983, Straw et al. 1986).

In Todt's (1989) survey of birds along the Ohio River, he found higher numbers and diversity in the section of river characterized by floodplain forest, agricultural areas, and an island. He suggested that birds could be used as indicators of environmental quality for the Ohio River.

Anurans.--This group is composed of frogs and toads. Most of the species encountered in West Virginia, such as toads, cricket frogs, treefrogs, chorus frogs, and the wood frog (Rana sylvatica) are predominantly terrestrial during much of the year. Cover types for these species include upland forests, wooded thickets, wet meadows, and vegetated shorelines (Green and 
Pauley 1987, Semlitsch 2000). In the spring they migrate to shallow pools, swamps, or slow moving streams and rivers to spawn. At different times during the breeding season large choruses of calling males can form. After the breeding season, the adults and transformed young return to terrestrial areas (Green and Pauley 1987, Semlitsch 2000).

Other species, such as American bullfrogs and green frogs (Rana clamitans) are more dependent on permanent water year-round. These species are typically found along the shores of lakes, streams, and rivers (Green and Pauley 1987). In winter they will hibernate in the mud at the bottom of these waterbodies (Green and Pauley 1987). Green frogs are more solitary than other species, and normally will not form large choruses during the breeding season (Green and Pauley 1987).

The American bullfrog, green frog, and American toad, are 3 of only a small number of amphibian species known to regularly coexist with predatory fish (Kats et al. 1988, Hecnar and M'Closkey 1997, Semlitsch 2002). This is largely due to tadpole anitipredator behavior, chemical defenses, and adult behavior modifications (Voris and Bacon 1966, Licht 1968, Petranka et al. 1987, Kats et al. 1988, Semlitsch 2002). Ranid frogs (e.g., American bullfrogs, green frogs, pickerel frogs [Rana palustris], and northern leopard frogs [Rana pipiens]) are believed to lesson the impact of fish predation due to being relatively large-bodied and by having large clutch sizes (Hecnar and M'Closkey 1997). Also, the larvae of green frogs and bullfrogs are unpalatable to fish (Kats et. al. 1988). Similarly, American toads have toxic eggs, larvae, and adults (Voris and Bacon 1966, Licht 1968). However, other ranid frogs such as northern leopard frogs have palatable larvae (Hecnar and M'Closkey 1997). Species such as spring peepers, mountain chorus frogs (Pseudacris brachyphona), and Cope's gray treefrogs (Hyla chrysoscelis), all have palatable larvae and were found to occur less often than expected in ponds with 
predatory fish (Hecnar and M'Closkey 1997). Cope's gray treefrogs were found in a laboratory setting to elicit an avoidance response specifically due to the presence of fish (Petranka et al. 1987). Additionally, adults were found to alter their choice of calling and oviposition sites due to predators or competitors (Resetarits and Wilbur 1989, 1991). It is possible that the larvae of Cope's gray treefrogs avoid predation due to their bright reddish orange tail fins, which might deflect attacks away from their body (Caldwell 1982, Hecnar and M'Closkey 1997).

Anuran use of the Ohio River channel is undoubtedly affected by the presence of predatory fish. Tolin and Schettig (1983) found American toads to be the most common amphibian species inhabiting the Ohio River islands. They observed toads and ranid frogs associated with the unconsolidated shorelines of the islands and around tree roots and debris.

The use of river systems by anurans also is greatly influenced by channel morphology and hydrology. For species attempting to breed, a high current velocity can sweep away eggs (Kupferberg 1996). For this reason, the back channels of the Ohio River are likely more conducive for breeding anurans than the main channel, due to having greater protection from high currents and wind, as well as a lack of commercial barge traffic (USFWS 2002). However, widely fluctuating river stages also can damage eggs through desiccation (Kupferberg 1996). Kupferberg (1996) suggested that river enhancement plans for yellow-legged frogs (Rana boylii) in California should include providing broad, shallow channels with stable, large-boulder substrates that do not move under high flow conditions. Additionally, low-slope benches elevated above the thalweg were suggested to protect nesting areas from discharge fluctuations (Kupferberg 1996).

Anurans are considered an important prey base for many other species (Licht 1968, Turner and Fowler 1981). Due to their sensitivity to environmental changes, such as pollution 
and habitat alterations, anurans also are considered excellent indicators of environmental quality (Hall 1980, Hine 1982, Klemens 1993, Heyer et al. 1994).

Declines in anuran populations have been observed worldwide since the 1980s (Barinaga 1990, Blaustein and Wake 1990, Houlahan et al. 2000, Semlitsch 2002). In addition, a number of malformed individuals have been observed throughout North America since 1995 (Fort et al. 1999, Gardiner and Hoppe 1999, Sessions et al. 1999, Meteyer et al. 2000). These factors have led to an increased need to better understand those elements necessary for anuran conservation (Semlitsch 2000, 2002). The North American Amphibian Monitoring Program was established by the USFWS to address these issues (J. Casey and J. Record, unpublished report).

Turtles.--Turtles may be extremely important as a component of food webs, and in the energy flow and nutrient cycling of riparian ecosystems (Thompson 1993, Moll and Moll 2000). There is the potential for turtles to contribute significantly to the biomass of a community (Congdon et al. 1986, Moll 1990). Furthermore, due to their long life and dependence on both aquatic and terrestrial areas, turtles also may be excellent indicators of the effects of long-term habitat alterations (Tinkle et al. 1981, Burke and Gibbons 1995) and chemical contamination (Meyers-Schöne and Walton 1994).

Many studies have examined the habitat characteristics of turtle populations in riparian ecosystems. DonnerWright et al. (1999) found that snapping turtles and painted turtles were mostly associated with the slower, backwater areas of a river. Conversely, spiny softshells were attracted to fast, deep waters, and northern map turtles (Graptemys geographica) preferred a meandering channel with gravel substrate. Bodie and Semlitsch (2000) found that slough and scour areas were favored by false map turtles (G. pseudogeographica) and slider turtles (Trachemys scripta) along the Missouri River. Pluto and Bellis (1986) found that large adult 
northern map turtles were found in deeper sections of a river, farther from shore. Due to their smaller size and weaker swimming ability, juveniles were more dependent on shallow areas near shore. Lindemann (1999) noted the importance of deadwood as basking sites for map turtles. River cooters (Pseudemys concinna), on the New River in southern West Virginia, were found to use pools containing slow current, shallow water, beds of aquatic vegetation, and basking sites (Buhlmann and Vaughan 1991).

Terrestrial areas also need to be considered as they pertain to turtle conservation. A 275 m terrestrial buffer zone would have been necessary to protect $100 \%$ of the nest and hibernation sites of freshwater turtles in a Florida study (Burke and Gibbons 1995). A zone $449 \mathrm{~m}$ wide would have encompassed $95 \%$ of movements by a population of turtles along the Missouri River (Bodie and Semlitsch 2000). Bennet et al. (1970) found mud turtles (Kinosternon subrubrum) nesting up to $600 \mathrm{~m}$ away from water, although $80 \%$ of the turtles moved $\leq 90 \mathrm{~m}$ from shore. Buhlmann and Vaughan (1991) found river cooters hibernating in 1-2 m deep backwater areas with soft substrates. Softshell turtles (Apalone spp.) are dependent on high sandy ridges or sand bars for nesting (Plummer 1976). In Wisconsin, nests of spiny softshells were found $>100 \mathrm{~m}$ from water (Vogt 1981).

Turtle populations throughout North America are in serious decline (Lovich 1995, Klemens 2000) due to loss of habitat (Mitchell and Klemens 2000). In riparian ecosystems, human activities most negatively affecting turtle populations include channel and shoreline modifications, agricultural and urban runoff, and industrial discharges (Mitchell and Klemens 2000). Channel and shoreline modifications, in particular, simplify and reduce turtle habitat diversity by eliminating sandbars, pools, and riffles, and, in general, reduce aquatic productivity (Moll and Moll 2000). For example, habitat for yellow-blotched map turtles (Graptemys 
flavimaculata) in the Pascagoula River, Mississippi, was degraded by the removal of logs and snags, as well as by increased sedimentation and turbidity from mining activities and channelization (USFWS 1993). Smooth softshell turtles (Apalone mutica) suffered a population decline in Illinois after erosion silted over nesting beaches (Moll 1980). In Alabama, flattened musk turtles (Sternotherus depressus) have been negatively affected by siltation, pollution, changes in water level and streamflow, reduction of prey resources, and physical alteration of cover resulting primarily from mining activities (Dodd et al. 1988, USFWS 1990). In general, habitat specialists, such as Blanding's turtles (Emydoidea blandingii), Illinois mud turtles (Kinosternon flavescens spooneri), and smooth softshell turtles, are most affected by human activities. Conversely, generalists, such as spiny softshell turtles and snapping turtles have been observed to thrive in such environments (Moll 1980). Snapping turtles, in particular, are known to be highly tolerant of chemical pollutants and heavy metals (Helwig and Hora 1983, Bryan et al. 1987), although the long-term effects to exposure of these materials are unknown (Mitchell and Klemens 2000).

Riparian Furbearing Mammals.--Two furbearing mammals that are particularly dependent on riparian ecosystems, and known to commonly occur on and around the Ohio River islands, are beavers and muskrat (USFWS 2002). Both require areas with permanent still or slow moving water, and aquatic vegetation (Errington 1963, Slough and Sadleir 1977, Howard 1985). Hesse (1996) noted that the pre-altered Missouri River, with its many backwaters and sloughs likely supported populations of beavers, muskrat, and mink much greater than anything known at present.

Howard and Larson (1985) developed a model for habitat selection of beavers using streams with channels $<8 \mathrm{~m}$ wide. They found that animals tended to prefer wide channels with 
a low gradient. Proulx and Gilbert (1983) found that muskrat were dependent on an interspersion of open water and vegetation in which each habitat feature covered at least $25 \%$ of the animals' home ranges. Both species will build bank burrows (Jenkins and Busher 1979, Willner et al. 1980). Messier and Virgil (1992) found that muskrat preferred to use bank burrows to lodges at low population sizes. They further observed that muskrat colonization tended to occur first along island shorelines. Both species also are dependent on a shoreline area of herbaceous vegetation (Errington 1963, Jenkins 1981). Beavers additionally require areas of woody vegetation primarily used as winter food (Jenkins 1979).

Beavers and muskrat benefit additional wetland species primarily as a result of their cover type modifications (Percy 1982, Edwards and Otis 1999). Muskrat are a significant vertebrate consumer of emergent vegetation (Clark 1994). Kaminski and Prince (1981) found that muskrat activity resulted in high avian diversity and increased waterfowl use of marshes. Additionally, Bulmer (1974) found that an increase in muskrat population resulted in an increase in mink population. Mink also are known to inhabit the Ohio River islands and associated areas, though in a lower abundance than beavers or muskrat (USFWS 2002, P. Morrison, USFWS, personal communication). Wetlands created or modified by beavers are preferred habitat for waterfowl such as wood ducks (Haramis 1990) and American black ducks (Anas rubripes; Diefenbach and Owen 1989).

Everett and Anthony (1976) analyzed muskrat tissues for heavy metal concentration. Positive correlations were found between levels of cadmium, zinc and copper in the tissues versus samples from plants. It was suggested that muskrat could be used as an indicator of heavy metal pollution in aquatic systems. 


\section{Habitat Evaluation}

Habitat Suitability Index (HSI) models were originally developed by the USFWS as part of the Habitat Evaluation Procedures. The purpose of these models is to document the quality of habitat for selected wildlife species (USFWS 1980). The models are based on measurements of structural variables necessary for important life requisites of individual species. Each variable is scored from $0-1$, and then entered into a formula to calculate a final HSI score, also $0-1$. The higher the final HSI, the better the habitat quality for that species (USFWS 1981).

There are 4 main assumptions concerning HSI models (Schamberger et al. 1978, Morrison et al. 1992). One is the idea that habitat suitability can be quantified. Second, that habitat suitability can be reflected by various habitat characteristics. Third, that habitat suitability for all species can be determined by evaluating the suitability for a selected species. Finally, that habitat quality and quantity are linearly related to animal abundance (USFWS 1981).

The validity of HSI models has been questioned (Cole and Smith 1983). Clark and Lewis (1983) found that call counts and HSI values were not strongly related for clapper rails (Rallus longirostris). Cook and Irwin (1985) had positive results with the pronghorn (Antilocapra americana) model, but several alterations were necessary to improve the model's performance. Robel et al. (1993) concluded that the HSI for the beaver could not accurately be used for habitat occupied by that species in Kansas. Bender et al. (1996) found that highly variable (0.38-0.81) HSI scores for the gray squirrel (Scirus carolinensis) were not statistically different when confidence intervals were included. Roloff and Kernohan (1999) evaluated several validation studies and rated them according to criteria such as input data variability, validity of test(s) used, scale, range of HSIs, population index, and study duration. They found all of the studies to be 
deficient to some extent. Recognizing the need for habitat assessments that are repeatable, credible, and defensible, Roloff and Kernohan (1999) suggested that HSI models could be used if several criteria are taken into account. This includes properly applying the model to the study area and season (Van Horne and Wiens 1991), using a statistically sound sampling design, identifying model assumptions, and applying confidence intervals to the HSI scores (Bender et al. 1996).

In 2002, there were 158 HSI models available in published form. For this study, HSI models for the wood duck, belted kingfisher, muskrat, mink, great blue heron, and snapping turtle were chosen. These species are commonly associated with riparian areas and exist along the Ohio River (Tolin and Schettig 1983, USFWS 2002). They also are representative of different taxonomic groups. Furthermore, the variables measured in accordance with these models should provide a thorough representation of the overall quality of habitat in the study area. The models that were used in this study are summarized below:

Wood duck.--The wood duck model is designed to evaluate an area as breeding (spring and summer) habitat (Sousa and Farmer 1983). A food component is left out, with the assumption that brood-rearing cover also will provide a sufficient food supply. The nesting component of this model takes into account the number of adequate natural cavities, as well as any artificial nest boxes in the area. The brood-rearing component evaluates the percent of the water surface that's covered by overhanging shrubs and tree crowns $(\leq 1 \mathrm{~m}$ from the water surface), woody structure, and herbaceous vegetation. Although not specified in the model, this also can be considered good quality nonbreeding habitat for the species (Gilmer et al. 1977, McGilvrey 1968, Haramis 1990). Only the brood-rearing component was used in this study. Most wood duck broods on the Ohio River were observed in early to mid-summer (Chapter 2), 
therefore, summer was considered the most appropriate season to apply the brood-rearing component to. Evaluation of the nesting component was beyond the scope of this project.

There also is a separate model to evaluate the potential for an area to serve as winter (fall and winter) cover (Sousa and Farmer 1983). This is essentially the same model as the broodrearing component of the breeding model, with winter-persistent herbaceous plants being the only type of herbaceous vegetation taken into account. Although specified as winter cover, the model states that it can be applied to both the fall and winter seasons. Thus, this model likely can predict quality fall and spring migration habitat as well. The appropriateness of using this model depends on whether or not the area in question falls within the normal winter range for the wood duck. The Ohio River of West Virginia is on the northern edge of this range (Bellrose 1980); hence the winter model was included in this study.

Belted kingfisher.--The model to evaluate potential belted kingfisher habitat considers the availability of foraging areas, cover in the form of perches, and nesting sites (Prose 1985). The appropriate seasons for this model are spring and summer. Foraging areas for riverine cover types are evaluated by measuring water clarity, percent of the water area covered by surface obstructions (woody material $\leq 1 \mathrm{~m}$ from the water's surface and herbaceous vegetation), percent of the water area $\leq 60 \mathrm{~cm}$ in depth $\leq 15 \mathrm{~m}$ from shore, and the amount of riffles present. The availability of suitable perches that a kingfisher can use is measured by determining the average number of $25-\mathrm{m}$ stream subsections containing $\geq 1$ open perches located immediately adjacent to or over the water. The reproduction variable in this model is the distance from the shoreline to a suitable soil bank that a kingfisher can use to construct a nesting burrow. A suitable soil bank is one that is $\geq 1.3 \mathrm{~m}$ in height with soil containing $70-96 \%$ sand and $\leq 15 \%$ clay. 
Muskrat.--I used the freshwater HSI model to evaluate year-round muskrat habitat (Allen and Hoffman 1984). For the freshwater model and a riverine cover type, the life requisites examined are cover and food. The cover component is evaluated by measuring the percent of the year with surface water present, the percent stream gradient, and the percent of emergent herbaceous vegetation within the channel. This final variable also is used to determine the food component, as is the percent herbaceous canopy cover $\leq 10 \mathrm{~m}$ from the water's edge.

Mink.--The HSI model used to evaluate year-round mink habitat is broken up into several different cover types (Allen 1984). The riverine cover type evaluates an area based on a combined food and cover component. The 2 variables measured are percent of the year with surface water present and the percent tree and/or shrub canopy cover within $100 \mathrm{~m}$ of the water's edge. A separate food component is not included because it is assumed that an area containing permanent water for at least 9 months of the year and sufficient vegetation adjacent to the water's edge will provide an adequate food source.

Great blue heron.--The great blue heron model examines an area for the potential to serve as foraging habitat and nesting habitat (Short and Cooper 1985). The appropriate seasons to apply this model to are spring and summer. Only aquatic areas are included in the foraging habitat component of this model, although it is understood that herons can forage in upland sites. Furthermore, although herons have nested on artificial structures, this model only considers trees as potential nest sites. The potential foraging habitat of an area is evaluated by determining if there exists a body of water with a suitable prey base and a disturbance-free zone up to $100 \mathrm{~m}$ around the site. The presence of a protected forested area within $250 \mathrm{~m}$ of a wetland containing suitable nesting trees is used to evaluate potential nesting use. Two other variables measured are the distance between potential nesting and foraging areas and the proximity of potential nest sites 
to active nest sites.

Snapping turtle.--The snapping turtle model evaluates an area for the potential to provide food, winter cover, reproductive cover, and access to permanent water (Graves and Anderson 1987). Considering this species general diet, the food component of this model is evaluated through water temperature and velocity, 2 factors that influence foraging activity. The abundance of aquatic vegetation also is measured as a function of the turtle's diet. Winter cover is evaluated by determining the potential ice cover of a wetland and the percent of silt in the substrate. The quality of an area to serve the turtle's reproduction needs is determined by measuring the distance from the primary wetland to a small stream. Adult females are known to move up small streams to nest. Subsequently, juvenile turtles will initially use these areas instead of larger wetlands. All snapping turtles require areas of permanent water, so the final variable measured for this model is the distance to a permanent water source.

\section{STUDY ORGANIZATION}

The research findings presented here are divided into 3 chapters. In chapter 2, I present data regarding species diversity, richness, and relative abundance of waterbirds, anurans, turtles, beavers, and muskrat on back channel and main channel areas associated with islands on the Ohio River. In Chapter 3, I present data from the analyses of 5 HSI models for back channel and main channel areas. All results were compared for differences between channels (back and main), sides (island and mainland) and treatments (back channel-mainland, back channel-island, main channel-mainland, and main channel-island). 


\section{QUALITY ASSURANCE AND QUALITY CONTROL}

Quality assurance for this project included requiring me to have the proper training and experience to complete the necessary surveys, habitat evaluations, and data analyses. As most fieldwork was completed by boat, I was certified in the Department of the Interior Motorboat Operator Certification Course. In addition, I ensured that my technicians were properly trained before assisting me in the field. My primary advisor, Dr. James Anderson, performed spot checks to ensure proper species identification and survey protocols. Dr. Thomas Pauley, from Marshall University, advised me on turtle trapping techniques. Dr. George Seidel provided statistical advice and assistance. Quality control was ensured through replication of study islands, surveys, and other evaluations.

\section{LITERATURE CITED}

Allen, A. W. 1984. Habitat suitability index models: mink. U. S. Fish and Wildlife Service. FWS/OBS-82/10.61 Revised.

Allen, A. W., and R. D. Hoffman. 1984. Habitat suitability index models: muskrat. U. S. Fish and Wildlife Service. FWS/OBS-82/10.46.

Barinaga, M. 1990. Where have all the froggies gone? Science 247:1033-1034.

Bellrose, F. C. 1980. Ducks, geese and swans of North America. Stackpole Books, Harrisburg, Pennsylvania, USA.

Bender, L. C., G. J. Roloff, and J. B. Haufler. 1996. Evaluating confidence intervals for habitat suitability models. Wildlife Society Bulletin 24:347-352.

Bennett, D. H., J. W. Gibbons, and J. C. Franson. 1970. Terrestrial activity in aquatic turtles. Ecology 51:738-740. 
Blaustein, A. R., and D. B. Wake. 1990. Declining amphibian populations: a global phenomenon? Trends in Ecological Evolution 5:203-204.

Bodie, J. R., and R. D. Semlitsch. 2000. Spatial and temporal use of floodplain habitats by lentic and lotic species of aquatic turtles. Oecologia 122:138-146.

Brinson, M. M., B. L. Swift, R. C. Plantico, and J. S. Barclay. 1981. Riparian ecosystems: their ecology and status. U. S. Fish and Wildlife Service. FWS/OBS-81/17.

Bryan, A. M., P. G. Olafsson, and W. B. Stone. 1987. Disposition of low and high environmental concentrations of PCBs in snapping turtle tissues. Bulletin of Environmental Contamination and Toxicology 38:1000-1005.

Buhlmann, K. A., and M. R. Vaughan. 1991. Ecology of the turtle Pseudemys concinna in the New River, West Virginia. Journal of Herpetology 25:72-78.

Bulmer, M. G. 1974. A statistical analysis of the 10-year cycle in Canada. Journal of Animal Ecology 43:701-718.

Burke, V. J., and J. W. Gibbons. 1995. Terrestrial buffer zones and wetland conservation: a case study of freshwater turtles in a Carolina bay. Conservation Biology 9:1365-1369.

Caldwell, J. P. 1982. Disruptive selection: a tail color polymorphism in Acris tadpoles in response to differential predation. Canadian Journal of Zoology 60:2817-2818.

Clark, J. D., and J. C. Lewis. 1983. A validity test of a habitat suitability index model for clapper rail. Proceedings of the Annual Conference of the Southeastern Association of Fish and Wildlife Agencies 37:95-102.

Clark, W. R. 1994. Habitat selection by muskrats in experimental marshes undergoing succession. Canadian Journal of Zoology 72:675-680.

Cole, C. A., and R. L. Smith. 1983. Habitat suitability indices for monitoring wildlife 
populations- an evaluation. Transactions of the North American Wildlife and Natural Resources Conference 48:367-375.

Congdon, J. D., J. L. Greene, and J. W. Gibbons. 1986. Biomass of freshwater turtles: a geographic comparison. American Midland Naturalist 115:165-173.

Conway, C. J. 1995. Virginia Rail (Rallus limicoloa). In A. Poole and F. Gill, editors. The Birds of North America, No. 173. The Academy of Natural Sciences, Philadelphia, Pennsylvania, and The American Ornithologists' Union, Washington, D. C., USA.

Cook, J. G., and L. L. Irwin. 1985. Validation and modification of a habitat suitability model for pronghorns. Wildlife Society Bulletin 13:440-448.

Cottrell, S. D., H. H. Prince, and P. I. Padding. 1990. Nest success, duckling survival, and brood habitat selection of wood ducks in a Tennessee riverine system. Pages 191-197 in L. H. Fredrickson, G. V. Burger, S. P. Havera, D. A. Graber, R. E. Kirby, and T. S. Taylor, editors. Proceedings of the 1988 North American Wood Duck Symposium, St. Louis, Missouri, USA.

Cowardin, L. M., V. Carter, F. C. Golet, and E. T. LaRoe. 1979. Classification of wetlands and deepwater habitats of the United States. U. S. Fish and Wildlife Service. FWS/OBS$79 / 31$.

Cramer, Z. 1814. The navigator; containing directions for navigating the Monongahela, Allegheny, Ohio, and Mississippi Rivers. Cramer, Spear, and Eichbaum, Pittsburgh, Pennsylvania, USA. Republished in 1979 by McDowell Publications, Utica, Kentucky, USA.

Diefenbach, D. R., and R. B. Owen, Jr. 1989. A model of habitat use by breeding American black ducks. Journal of Wildlife Management 53:383-389. 
Dodd, C. K., Jr., K. M. Enge., and J. N. Stuart. 1988. Aspects of the biology of the flattened musk turtle, Sternotherus depressus, in Alabama. Bulletin of the Florida State Museum of Biological Sciences 34:1-64.

DonnerWright, D. M., M. A. Bozek, J. R. Probst, and E. M. Anderson. 1999. Response of turtle assemblage to environmental gradients in the St., Croix River in Minnesota and Wisconsin, U.S.A. Canadian Journal of Zoology 77:989-1000.

Edwards, N. T., and D. L. Otis. 1999. Avian communities and habitat relationships in South Carolina piedmont beaver ponds. American Midland Naturalist 141:158-171.

Errington, P. L. 1963. Muskrat populations. Iowa State University Press, Ames, Iowa, USA.

Evans, J., and S. Wilson. 1982. Wildlife value of wetlands in West Virginia. Pages 213-220 in B. R. McDonald, editor. Symposium on wetlands of the Unglaciated Appalachian Region, Morgantown, West Virginia, USA.

Everett, J. J., and R. G. Anthony. 1976. Heavy metal accumulation in muskrats in relation to water quality. Transactions of the Northeastern Fish and Wildlife Conference 33:105116.

Fort, D. J., R. L. Rogers, H. F. Copley, L. A. Bruning, E. L. Stover, J. D. Helgen, and J. B. Burkhart. 1999. Effects of pond water, sediment, and sediment extracts from Minnesota and Vermont, USA, on early development and metamorphosis of Xenopus. Environmental Toxicology and Chemistry 18:2305-2315.

Frost, S. L., and W. J. Mitsch. 1989. Resource development and conservation history along the Ohio River. Ohio Journal of Science 89:143-152.

Funk, J. J., and J. W. Robinson. 1974. Changes in the channel of the lower Missouri River and effects on fish and wildlife. Missouri Department of Conservation, Aquatic Series 11, 
Jefferson City, Missouri, USA.

Gardiner, D. M., and D. M. Hoppe. 1999. Environmentally induced limb malformations in mink frogs (Rana septentrionalis). Journal of Experimental Zoology 284:207-216.

Gilmer, D. S, R. E. Kirby, I. J. Ball, and J. H. Riechmann. 1977. Post-breeding activities of mallards and wood ducks in north-central Minnesota. Journal of Wildlife Management 41:345-359.

Graves, B. M., and S. H. Anderson. 1987. Habitat suitability index models: snapping turtle. U. S. Fish and Wildlife Service Biological Report 82(10.141).

Green, N. B., and T. K. Pauley. 1987. Amphibians and reptiles in West Virginia. University of Pittsburgh Press, Pittsburgh, Pennsylvania, USA.

Hall, R. J. 1980. Effects of environmental contaminants on reptiles: a review. U. S. Fish and Wildlife Service Special Scientific Report 228.

Haramis, G. M. 1990. The breeding ecology of the wood duck: a review. Pages 45-60 in L. H. Fredrickson, G. V. Burger, S. P. Havera, D. A. Graber, R. E. Kirby, and T. S. Taylor, editors. Proceedings of the 1988 North American Wood Duck Symposium, St. Louis, Missouri, USA.

Hamas, M. J. 1994. Belted kingfisher, Ceryle alcyon (Coraciiformes: Alcedinidae). In A. Poole, P. Stettenheim, and F. Gill, editors. The Birds of North America, No. 84. The Academy of Natural Sciences, Philadelphia, Pennsylvania, and The American Ornithologists' Union, Washington, D. C., USA.

Hecnar, S. J., and R. T. M'Closkey. 1997. The effects of predatory fish on amphibian species richness and distribution. Biological Conservation 79:123-131.

Helwig, D. D., and M. E. Hora. 1983. Polychlorinated biphenyl, mercury, and cadmium 
concentrations in Minnesota snapping turtles. Bulletin of Environmental Contamination and Toxicology 30:186-190.

Hesse, L. W. 1996. Floral and faunal trends in the middle Missouri River. Pages 73-90 in Galat, D. L., and Frazier, A. G., editors. Overview of river-floodplain ecology in the Upper Mississippi River Basin, v. 3 of Kelmelis, J. A., editor. Science for floodplain management into the $21^{\text {st }}$ century, Washington, D. C., USA.

Heyer, W., M. Donnelly, R. McDiarmid, L. Hayek, and M. Foster. 1994. Measuring and monitoring biological diversity, standard methods for amphibians. Smithsonian Institution Press, Washington, D. C., USA.

Hine, R. L. 1982. Creatures of the night. Wisconsin Academic Review, Madison, Wisconsin, USA.

Hocutt, G. E., and R. W. Dimmick. 1971. Summer food habits of juvenile wood ducks in east Tennessee. Journal of Wildlife Management 35:286-292.

Houlahan, J. E., C. S. Findlay, B. R. Schmidt, A. H. Meyers, and S. L. Kuzmin. 2000. Quantitative evidence for global amphibian declines. Nature 404:752-755.

Howard, R. J., and J. S. Larson. 1985. A stream habitat classification system for beaver. Journal of Wildlife Management 49:19-25.

Jenkins, S. H. 1979. Seasonal and year-to-year differences in food selection by beavers. Oecologia. (Berl.) 44:112-116.

Jenkins, S. H. 1981. Problems, progress, and prospects in studies of food selection by beavers. Pages 559-579 in J. A. Chapman and D. Pursley, editors. Volume 1. Worldwide Furbearer Conference Proceedings.

Jenkins, S. H., and P. E. Busher. 1979. Castor canadensis. Mammalian Species 120:1-8. 
Johnson, B. L., W. B. Richardson, and T. J. Naimo. 1995. Past, present, and future concepts in large river ecology. BioScience 45:134-141.

Kaminski, R. M., and H. H. Prince. 1981. Dabbling duck and aquatic macroinvertebrate responses to manipulated wetland habitat. Journal of Wildlife Management 45:1-15.

Kaminski, R. M., R. W. Alexander, and B. D. Leopold. 1993. Wood duck and mallard winter microhabitats in Mississippi hardwood bottomlands. Journal of Wildlife Management $57: 562-570$.

Kats, L. B., J. W. Petranka, and A. Sih. 1988. Antipredator defenses and the persistence of amphibian larvae with fishes. Ecology 69:1865-1870.

Klemens, M. W. 1993. Amphibians and reptiles of Connecticut and adjacent regions. State Geological and Natural History Survey of Connecticut Bulletin 112.

Klemens, M. W. (ed.). 2000. Turtle Conservation. Smithsonian Institution Press, Washington, D. C., USA.

Korte, P. A., and L. H. Fredrickson. 1977. Loss of Missouri's lowland hardwood ecosystem. Transactions of the North American Wildlife and Natural Resources Conference 42:3141.

Kupferberg, S. J. 1996. Hydrologic and geomorphic factors affecting conservation of a riverbreeding frog (Rana boylii). Ecological Applications 6:1332-1344.

Laustrup, M. S., and C. D. Lowenberg. 1994. Development of a systemic land-cover/land-use database for the upper Mississippi River system derived from Landsat thematic mapper satellite data. National Biological Survey, Environmental Management Technical Center, Report LTRMP 94-T004, Onalaska, Wisconsin, USA.

Licht, L. E. 1968. Unpalatability and toxicity of toad eggs. Herpetologica 24:93-98. 
Lindeman, P. V. 1999. Surveys of basking map turtles Graptmys spp. in three river drainages and the importance of deadwood abundance. Biological Conservation 88:33-42.

Lovich, J. E. 1995. Turtles. Pages 118-121 in E. T. LaRoe, G. S. Farris, C. E. Puckett, P. D. Doran, and M. J. Mac, editors. Our living resources: a report to the nation on the distribution, abundance, and health of U. S. plants, animals, and ecosystems. U. S. Department of the Interior, National Biological Survey, Washington, D. C., USA.

McGilvrey, F. B. (compiler). 1968. A guide to wood duck production habitat requirements. Bureau of Sport Fish and Wildlife Resources Publication 60.

Melvin, S. M., and J. P. Gibbs. 1996. Sora, Porzana carolina. In A. Poole and F. Gill, editors. The Birds of North America, No. 250. The Academy of Natural Sciences, Philadelphia, Pennsylvania, and The American Ornithologists' Union, Washington, D. C., USA.

Messier, F., and J. A. Virgl. 1992. Differential use of bank burrows and lodges by muskrats, Ondatra zibethicus, in a northern marsh environment. Canadian Journal of Zoology 70:1180-1184.

Meteyer, C. U., I. K. Loeffler, J. F. Fallon, K. A. Converse, E. Green, J. C. Helgen, S. Kersten, R. Levey, L. Eaton-Poole, and J. G. Burkhart. 2000. Hind limb malformations in freeliving northern leopard frogs (Rana pipiens) from Maine, Minnesota, and Vermont suggest multiple etiologies. Teratology 62:151-171.

Meyers-Schöne, L., and B. T. Walton. 1994. Turtles as monitors of chemical contaminants in the environment. Pages 93-153 in G. W. Ware, editor. Reviews of Environmental Contamination and Toxicology, vol. 135. Springer-Verlag, New York, New York, USA. Millard, M. J. 1993. Nearshore habitat use by larval fishes near two islands in the upper Ohio River. Dissertation, West Virginia University, Morgantown, West Virginia, USA. 
Mitchell, J. C., and M. W. Klemens. 2000. Primary and secondary effects of habitat alteration. Pages 5-32 in M. W. Klemens, editor. Turtle Conservation. Smithsonian Institution Press, Washington, D. C., USA.

Moll, D. 1980. Dirty river turtles. Natural History 5:42-49.

Moll, D. 1990. Population sizes and foraging ecology in a tropical freshwater stream turtle community. Journal of Herpetology 24:48-53.

Moll, E. O., and D. Moll. 2000. Conservation of river turtles. Pages 126-155 in M. W. Klemens, editor. Turtle Conservation. Smithsonian Institution Press, Washington, D. C., USA.

Morrison, M. L., B. G. Marcot, and R. W. Mannan. 1992. Wildlife habitat relationships: concepts and applications. University of Wisconsin Press, Madison, Wisconsin, USA.

Naiman, R. J., H. Decamps, and M. Pollock. 1993. The role of riparian corridors in maintaining regional biodiversity. Ecological Applications 3:209-212.

Percy, H. R., Jr. 1982. Muskrats (Ondatra zibethica and Neofiber alleni). Pages 282-325 in J. A. Chapman and G. A. Feldhammer, editors. Wild Mammals of North America. Johns Hopkins University Press, Baltimore, Maryland, USA.

Petranka, J. W., L. B. Kats, and A. Sih. 1987. Predator-prey interactions among fish and larval amphibians: use of chemical cues to detect predatory fish. Animal Behaviour 35:420425.

Ploskey, G. R., and R. M. Jenkins. 1980. Inventory of U. S. reservoirs, January 1, 1980. U. S. Fish and Wildlife Service, National Reservoir Research Program, Fayetteville, Arkansas, USA.

Plummer, M. D. 1976. Some aspects of nesting success in the turtle, Trionyx muticus. 
Herpetologica 32:353-359.

Pluto, T. G., and E. D. Bellis. 1986. Habitat utilization by the turtle, Graptemys geographica, along a river. Journal of Herpetology 20:22-31.

Prose, B. L. 1985. Habitat suitability index models: belted kingfisher. U. S. Fish and Wildlife Service Biological Report 82(10.87).

Proulx, G., and F. F. Gilbert. 1983. The ecology of the muskrat (Ondatra zibethica) at Luther marsh, Ontario. Canadian Field-Naturalist 97:377-390.

Rabe, D. L., H. H. Prince, and D. L. Beaver. 1983. Feeding-site selection and foraging strategies of American woodcock. The Auk 100:711-716.

Raedeke, K., editor. 1989. Streamside management: riparian wildlife and forestry interactions. Contribution Number 59. Institute of Forest Resources, University of Washington, Seattle, Washington, USA.

Reid, G. K. 1961. Ecology of inland waters and estuaries. D. Van Nostrand Co., New York, New York, USA.

Resetarits, W. J., Jr., and H. M. Wilbur. 1989. Oviposition site choice in Hyla chrysoscelis: role of predators and competitors. Ecology 70:220-228.

Resetarits, W. J., Jr., and H. M. Wilbur. 1991. Calling site choice by Hyla chrysoscelis: effect of predators, competitors, and oviposition sites. Ecology 72:778-786.

Robel, R. J., L. B. Fox, and K. E. Kemp. 1993. Relationship between habitat suitability index values and ground counts of beaver colonies in Kansas. Wildlife Society Bulletin $21: 415-421$.

Roloff, G. J., and B. J. Kernohan. 1999. Evaluating reliability of habitat suitability index models. Wildlife Society Bulletin 27:973-985. 
Sacilotto, K. A. 2002. An assessment of natural cavity abundance, nest box use, and management recommendations for birds on the Ohio River Islands National Wildlife Refuge, West Virginia. Thesis, West Virginia University, Morgantown, West Virginia, USA.

Schamberger, M., C. Short, and A. Farmer. 1978. Evaluating wetlands as wildlife habitat. Pages 74-83 in P. E. Greeson et al., editors. Wetland functions and values: the state of our understanding. American Water Resources Association, Minneapolis, Minnesota, USA.

Semlitsch, R. D. 2000. Principles for management of aquatic-breeding amphibians. Journal of Wildlife Management 64:615-631.

Semlitsch, R. D. 2002. Critical elements for biologically based recovery plans of aquaticbreeding amphibians. Conservation Biology 16:619-629.

Sessions, S. K., R. A. Franssen, and V. L. Horner. 1999. Morphological clues from multilegged frogs: are retinoids to blame? Science 284:800-802.

Short, H. L., and R. J. Cooper. 1985. Habitat suitability index models: great blue heron. U. S. Fish and Wildlife Service Biological Report 82(10.99).

Slough, B. G., and R. M. F. S. Sadleir. 1977. A land capability classification system for beaver (Castor canadensis Kuhl). Canadian Journal of Zoology 55:1324-1335.

Smith, R. L., and L. D. Flake. 1985. Movements and habitat of brood-rearing wood ducks on a prairie river. Journal of Wildlife Management 49:437-442.

Sousa, P. J., and A. H. Farmer. 1983. Habitat suitability index models: wood duck. U. S. Fish and Wildlife Service. FWS/OBS-82/10.43.

Steiner, D. E. 2000. Notice of intent to prepare an environmental assessment for proposed 
authorization of an Ohio River ecosystem restoration program. Federal Register $65: 36674-36675$.

Straw, J. A., Jr., J. S. Wakeley, and J. E. Hudgins. 1986. A model for management of diurnal habitat for American woodcock in Pennsylvania. Journal of Wildlife Management 50:378-383.

The Nature Conservancy. 1992. The forested wetlands of the Mississippi River: an ecosystem in crisis. The Nature Conservancy, Baton Rouge, Louisiana, USA.

Thompson, D. H. 1979. Feeding areas of great blue herons and great egrets nesting within the floodplain of the upper Mississippi River. Proceedings of the 1978 Conference of the Colonial Waterbird Group 2:202-213.

Thompson, M. B. 1993. Hypothetical considerations of the biomass of chelid tortoises in the River Murray and the possible influences of predation of introduced foxes. Pages 219224 in D. Lunney and D. Ayers, editors. Herpetology in Australia - a Diverse Discipline. Transactions of the Royal Zoological Society of New South Wales, Mosman, Australia.

Thorp, J. H. 1992. Linkage between islands and benthos in the Ohio River, with implications for riverine management. Canadian Journal of Fisheries and Aquatic Sciences 49:18721882.

Tinkle, D. W., J. D. Congdon, and P. C. Rosen. 1981. Nesting frequency and success: implications for the demography of painted turtles. Ecology 51:738-740.

Todt, D. E. 1989. Birds in the Ohio River valley: possible indicators of environmental quality. Ohio Journal of Science 89:192-195.

Tolin, W. A., and P. A. Schettig. 1983. A physical and biological survey of the Ohio River islands (Huntington District). U. S. Fish and Wildlife Service, Elkins, West Virginia, 
USA.

Turner, L. J., and D. K. Fowler. 1981. Utilization of surface mine ponds in east Tennessee by breeding amphibians. U. S. Department of the Interior, Fish and Wildlife Service. FWS/OBS-81/08.

U. S. Army Corps of Engineers. 1981. Final environmental statement on Ohio River, PA to KY (mile 0 to mile 438) commercial sand and gravel dredging operations. U. S. Army Engineer District, Pittsburgh, Pennsylvania, USA.

U. S. Army Corps of Engineers. 1998. The Ohio River System. U. S. Army Corps of Engineers Pittsburgh District, Pittsburgh, Pennsylvania, USA.

U. S. Army Corps of Engineers. 2000. Ohio River ecosystem restoration program, integrated decision document and environmental assessment. U. S. Army Corps of Engineers, Great Lakes and Ohio River Division, Cincinnati, Ohio, USA.

U. S. Army Corps of Engineers. 2002a. Draft environmental impact statement on commercial sand and gravel dredging operations in the Allegheny and Ohio Rivers, Pennsylvania. U. S. Army Corps of Engineers, Pittsburgh District, Pittsburgh, Pennsylvania, USA.

U. S. Army Corps of Engineers. 2002b. Ohio River Ecosystem Restoration Program, civil works project fact sheet. U. S. Army Corps of Engineers, Louisville District, Louisville, Kentucky, USA.

U. S. Census Bureau. 2003. Online. World Wide Web. http://quickfacts.census.gov/qfd/

U. S. Department of Agriculture. 1960. Marshall County, West Virginia. U. S. Government Printing Office, Washington, D. D., USA.

U. S. Department of Agriculture. 1961. Jackson and Mason Counties, West Virginia. U. S. Government Printing Office, Washington, D.C., USA. 
U. S. Department of Agriculture. 1970. Wood and Wirt Counties, West Virginia. U. S. Government Printing Office, Washington, D.C., USA.

U. S. Department of Agriculture. 1989. Pleasants and Tyler Counties, West Virginia. U. S. Government Printing Office, Washington, D.C., USA.

U. S. Department of Agriculture. 1995. Wetzel County, West Virginia. U. S. Government Printing Office, Washington, D.C., USA.

U. S. Fish and Wildlife Service. 1980. Habitat evaluation procedures. U. S. Fish and Wildlife Service. ESM 102.

U. S. Fish and Wildlife Service. 1981. Standards for the development of habitat suitability index models. U. S. Fish and Wildlife Service, Release No. 1-81, 103 ESM 103.

U. S. Fish and Wildlife Service. 1989. Final environmental assessment, Ohio River Islands National Wildlife Refuge, proposal. U. S. Fish and Wildlife Service, Region 5, Newton Corner, Massachusetts, USA.

U. S. Fish and Wildlife Service. 1990. Flattened musk turtle recovery plan. U. S. Fish and Wildlife Service, Jackson, Michigan, USA.

U. S. Fish and Wildlife Service. 1993. Yellow-blotched map turtle (Graptemys flavimaculata) recovery plan. U. S. Fish and Wildlife Service, Jackson, Michigan, USA.

U. S. Fish and Wildlife Service. 1999. Strategic plan for conservation of Fish and Wildlife Service trust resources in the Ohio River valley ecosystem. U. S. Fish and Wildlife Service, Ohio River Valley Ecosystem Team.

U. S. Fish and Wildlife Service. 2000. Draft comprehensive conservation plan and environmental assessment, Ohio River Islands National Wildlife Refuge. U. S. Fish and Wildlife Service, Hadley, Massachusetts, USA. 
U. S. Fish and Wildlife Service. 2002. Ohio River Islands National Wildlife Refuge, comprehensive conservation plan. U. S. Fish and Wildlife Service, Parkersburg, West Virginia, USA.

U. S. Water Resources Council. 1971. Ohio River Basin comprehensive survey. U. S. Army Engineer Division, Ohio River, Cincinnati, Ohio, USA.

Van Horne, B., and J. A. Wiens. 1991. Forest bird habitat suitability models and the development of general habitat models. United States Fish and Wildlife Service Research 8 .

Vogt, R. C. 1981. Natural history of amphibians and reptiles of Wisconsin. Milwaukee Public Museum, Milwaukee, Wisconsin, USA.

Voris, H. K., and J. P. Bacon. 1966. Differential predation on tadpoles. Copeia 1966:594-598.

Weller, M. W. 1981. Freshwater marshes: ecology and wildlife management. University of Minnesota Press, Minneapolis, Minnesota, USA.

Weller, M. W. 1999. Wetland birds, habitat resources and conservation implications. Cambridge University Press, New York, New York, USA.

Weller, M. W., and W. E. Spatcher. 1965. Role of habitat in the distribution and abundance of marsh birds. Iowa Agricultural and Home Economics Experiment Station Special Report Number 43.

Willner, G. R., G. A. Feldhamer, E. E. Zucker, and J. A. Chapman. 1980. Ondatra zibethicus. Mammalian Species 141:1-8.

Zeto, M. A., W. A. Tolin, and J. E. Schmidt. 1987. The freshwater mussels, Unionidae, of the upper Ohio River, Greenup and Belleville Pools, West Virginia, USA. Nautilus 101:182185. 


\section{CHAPTER I. FIGURES}




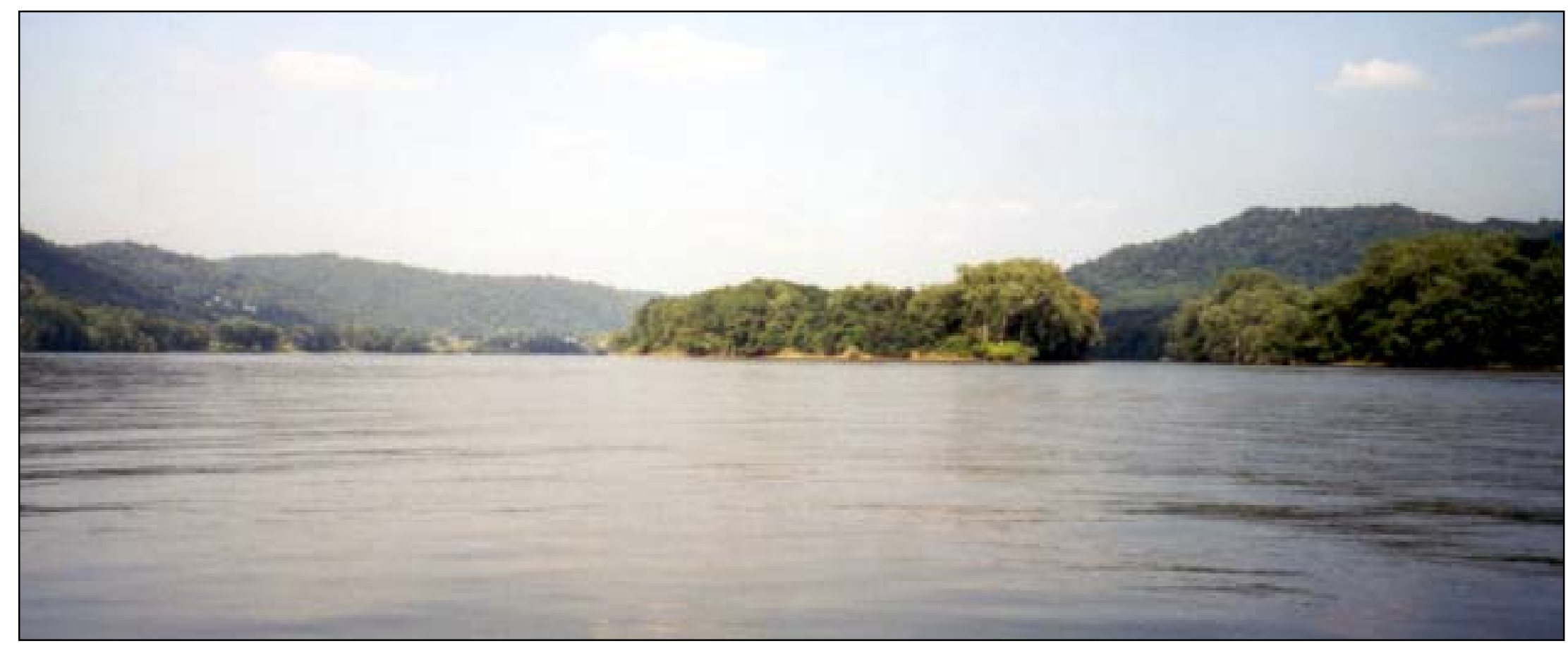

Figure 1. The main channel (left) and back channel (right) associated with Paden Island (center), Ohio River, West Virginia, 2001. 


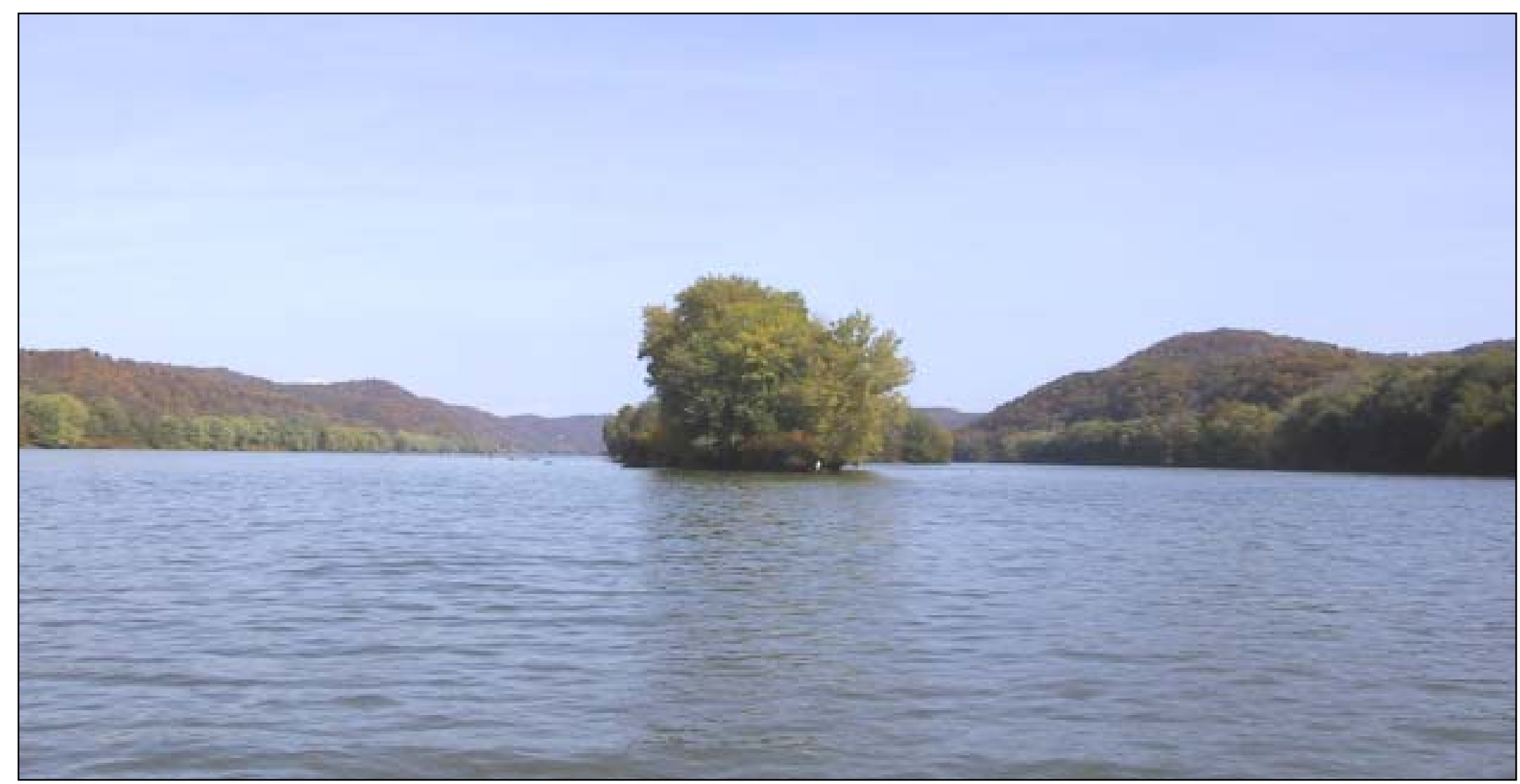

Figure 2. The main channel (left) and back channel (right) associated with Williamson Island (center), Ohio River, West Virginia, 2002 . 


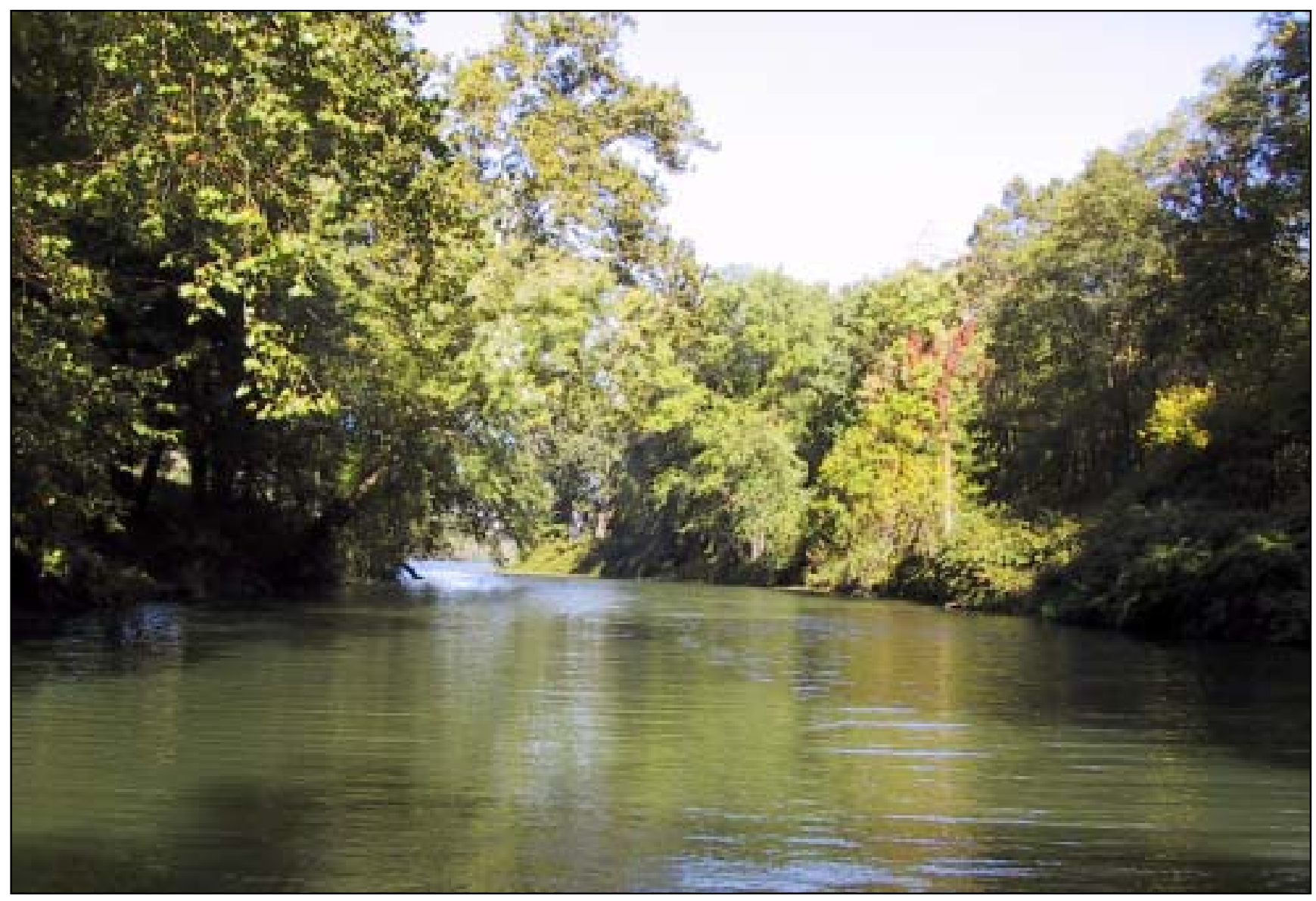

Figure 3. The back channel associated with Captina Island (left), Ohio River, West Virginia, 2002. 


\title{
CHAPTER II
}

\section{WILDLIFE USE OF BACK CHANNELS ASSOCIATED WITH ISLANDS ON THE OHIO RIVER, WEST VIRGINIA, U.S.A.}

\author{
ANDREW K. ZADNIK \\ azadnik@hotmail.com \\ West Virginia University \\ Division of Forestry \\ P. O. Box 6125 \\ Morgantown, WV 26506-6125
}


Abstract: The islands and associated back channels (areas to 1 side of the river and protected from commercial navigation) on the Ohio River are recognized as providing features critical for the habitat requirements of several species. However, quantitative information on this value is needed to assist natural resource managers in conserving these areas. I compared the relative abundance of waterbirds, turtles, anurans, and riparian furbearing mammals between back and main channels of the river. Wood duck (Aix sponsa) total abundance (birds/km) was higher on $\operatorname{back}(\bar{x}=1.73, S E=0.25)$ than main $(\bar{x}=0.55, S E=0.24)$ channels $(\mathrm{P}<0.001)$. Belted kingfisher (Ceryle alcyon) abundance was higher on main $(\bar{x}=0.95, S E=0.19)$ than back $(\bar{x}$ $=0.35, S E=0.08)$ channels $(\mathrm{P}=0.001)$ during the summer. The 2 most abundant turtle species encountered also showed opposite trends in channel selection. Spiny softshells (Apalone spinifera) were more abundant (turtles/trap-night) on main $(\bar{x}=0.24$, SE $=0.05)$ than back $(\bar{x}$ $=0.01, S E=0.01)$ channels $(\mathrm{P}<0.001)$ during the summer. Conversely, total snapping turtle (Chelydra serpentina) abundance was higher on back $(\bar{x}=0.17, S E=0.03)$ than main $(\bar{x}=$ 0.03, SE =0.01) channels $(\mathrm{P}<0.001)$. Anuran abundance (frequency of survey stations at which anurans were heard) was higher on back $(\bar{x}=0.54, S E=0.06)$ than main $(\bar{x}=0.17, S E$ $=0.05)$ channels $(\mathrm{P}<0.05)$ during the first survey period. Beaver (Castor canadensis) abundance (frequency of sign and direct observations) was greater on back $(\bar{x}=0.8, S E=0.04)$ than main $(\bar{x}=0.53, S E=0.05)$ channels $(\mathrm{P}<0.001)$. Muskrat (Ondatra zibethicus) also were more abundant on back $(\bar{x}=0.68, S E=0.05)$ than main $(\bar{x}=0.19, S E=0.04)$ channels $(\mathrm{P}<$ 0.001). These results show that back channels are important for species requiring abundant

This chapter written in the style of Conservation Biology 
cover and protection from the main current of the river. I recommend conserving back channel areas as critical riparian wildlife habitat.

Key words: Ohio River, island back channel, waterbirds, anurans, turtles, beaver, muskrat.

\section{Introduction}

The Ohio River has been dramatically altered over the past 200 years primarily due to industrialization and navigational projects (Tolin \& Schettig 1983). These activities essentially changed the Ohio from a free-flowing river to a series of connected lakes (Frost \& Mitsch 1989). Many of the islands on the river have been completely eliminated or severely degraded due to these activities (Tolin \& Schettig 1983; U. S. Army Corps of Engineers 2000). Current activities viewed as threats to the river and islands include commercial sand and gravel dredging, industrial development, gas/oil wells, logging, mooring activities, and to an extent, recreational activities and residential development (Tolin \& Schettig 1983; U. S. Fish and Wildlife Service 1989).

The islands and associated back channels on the Ohio River are generally believed to provide features considered critical for the habitat requirements of several wildlife species (Tolin \& Schettig 1983). The U. S. Fish and Wildlife Service (USFWS) has classified these areas as Resource Category 1, meaning they are unique and irreplaceable (USFWS 1989). Currently, many of the islands and some mainland tracts are protected from direct human exploitation as part of the Ohio River Islands National Wildlife Refuge (ORINWR). However, most of the back channels and back channel mainland shorelines remain under pressure to be developed (USFWS 2000). 
Few studies have quantitatively measured wildlife use of island back channels. The results of these studies are inconsistent regarding the use of these areas by certain taxa. Thorp (1992) found an increase in density and diversity of invertebrates related to the heterogeneity of island characteristics. He noted that the islands likely enhance snag formation and the input of organic matter, which have positive effects on macroinvertebrates. Zeto et al. (1987) found a high abundance and diversity of mussels inhabiting areas around islands in 2 navigational pools. Conversely, Millard (1993) found that several fish species appeared to avoid the back channel areas of 2 islands. He noted that turbidity along the shorelines during periods of wind or high flow could lower the quality of back channels as spawning and nursery habitat. Sacilotto (2002) found a lower abundance of birds on back channel compared to main channel sides in 2000, although abundance was similar between sides in 2001. In addition, bird diversity was similar between sides in 2000, although the back channel side had higher bird diversity than the main channel side in 2001 .

Nonconsumptive human activities are known to negatively affect waterbird populations. Thompson (1973) noted that human disturbance affected duck distribution on the Mississippi River. Havera et al. (1992) found that waterfowl were particularly disturbed by boating activities during fall migration. Klein (1993) showed experimentally that certain human activities disrupted waterbird foraging. Kaiser and Fritzell (1984) found that use of a main river channel by green herons (Butorides virescens) decreased as human use of the river increased.

Hesse (1996) noted that the habitat value for wildlife associated with river islands has been underrated. In fact, there is a lack of basic knowledge regarding wildlife inhabiting large river systems in general (Johnson et al. 1995). Wildlife typically associated with these areas includes waterbirds, anurans, turtles, and riparian furbearing mammals (Semlitsh 2000). 
Information on wildlife use of back channels is needed to assist the West Virginia Division of Natural Resources (WVDNR) in determining what, if any, types of activities are compatible with conserving these areas as critical wildlife habitat.

I examined back and main channels, and island and mainland sides, associated with 10 islands on the Ohio River and quantified species diversity, richness, and relative abundance of waterbirds, anurans, turtles, American beavers (hereafter beaver), and common muskrat (hereafter muskrat). I hypothesized that back channels, in particular the back channels along the island sides, would contain species not found on the main channel and would contain a greater abundance of species requiring woody and vegetative cover as a critical habitat component.

\section{Methods}

\section{Study Area}

I conducted this study on back and main channel areas associated with 10 islands (Captina, Paden, Williamson, Wells, Mill Creek, Middle, Buckley, Muskingum, Neal, and Buffington) on the Ohio River, West Virginia (Figure 1). These islands were chosen because they have "true" back channels, i.e., areas off to one side of the river that do not receive commercial barge traffic (P. Morrison, USFWS personal communication). These islands are part of the ORINWR (USFWS 2000). They occurred between river kilometer 174 and 349 in 4 separate navigational pools: Hannibal, Willow Island, Belleville, and Racine (USFWS 1989). Back channel areas totaled 136.90 ha $(\bar{x}=13.69, \mathrm{SE}=3.06$, range $0.92-39.9)$ in size, had a total channel length (averaged along the center of the channel) of $21.35 \mathrm{~km}(\bar{x}=2.14, \mathrm{SE}=0.38$, range $0.63-4.13$ $\mathrm{km})$, and a mean width of $0.11 \mathrm{~km}(\mathrm{SE}=0.02$, range $0.03-0.22 \mathrm{~km})$. Main channel areas 
associated with the islands had a mean width of $0.34 \mathrm{~km}(\mathrm{SE}=0.02$, range $0.24-0.42 \mathrm{~km}$; Appendix A).

The study area lies in the Low Hills Belt of the Mixed Mesophytic Forest Region of the Cumberland and Allegheny Plateaus (Braun 1950). The terrestrial cover types included various seral stages of the Bottomland Forest Type, characterized by deep, well-drained soils (Braun 1950). The types included mature bottomland hardwood, immature bottomland hardwood, late oldfield, early oldfield, knotweed (Polygonum cuspidatum), agricultural, unconsolidated shoreline, and urban/industrial areas (Tolin \& Schettig 1983).

The wetland cover types are broadly categorized as palustrine or riverine (Cowardin et al. 1979). Palustrine areas included palustrine unconsolidated bottom, palustrine emergent, palustrine scrub-shrub, and palustrine forested (Tolin \& Schettig 1983). Riverine areas included riverine aquatic bed, riverine emergent, riverine rock bottom, and riverine unconsolidated bottom (Cowardin et al. 1979; Tolin \& Schettig 1983).

The Ohio River itself is classified as riverine lower perennial modified by impoundments (Cowardin et al. 1979). Low gradient and slow water velocity characterize this type, as well as lack of any tidal influence. According to the U. S. Army Corps of Engineers (1981), the river averages $0.40 \mathrm{~km}$ wide with an average gradient of $0.10 \mathrm{~m} / \mathrm{km}$. The islands were formed by the accumulation of sand and gravel outwash during periods of extreme ice melt (Reid 1961). This initial accumulation and the subsequent actions of the river have led to the islands being generally tear-drop or crescent shaped, with round, shallow heads, and narrow, pointed toes. The shallow fronts consisted of gravel and cobbles that, on many of the islands, had been severely degraded due to dredging operations (Tolin \& Schettig 1983). The sides of the islands typically dropped off to form deep pockets. The toes sloped off gradually for some distance (Tolin \& 
Schettig 1983). The aquatic substrates consisted of muck, detritus, silt, clay, sand, gravel, cobble, riprap, emergent and submergent stumps and logs, and emergent and submergent aquatic beds (Tolin \& Schettig 1983).

The climate of the study area is moderate. The average yearly temperature for West Virginia, from $1895-2002$, was $11.05^{\circ} \mathrm{C}$ (range $=9.44-12.61$; National Climatic Data Center 2003). The average annual precipitation was $111.84 \mathrm{~cm}($ range $=65.38-153.16)$. Daily temperatures during 2001-2002 at Huntington, West Virginia, USA ( 154 km southwest from the midpoint of the study area) ranged from $0.06-25.17^{\circ} \mathrm{C}(\bar{x}=13.61, \mathrm{SE}=1.72)$. Monthly precipitation ranged from $2.79-22.56 \mathrm{~cm}(\bar{x}=8.90, \mathrm{SE}=1.14$; National Weather Service 2003).

\section{Study Design}

For this study, the area around each island was divided into 4 treatments based on combinations of channel and side: the back channel near the mainland side (back channel-mainland or BM), the back channel near the island side (BI), the main channel near the island side (MI), and the main channel near the mainland side (MM; Figure 2). Thus, there were 2 treatments for each channel $($ back $=\mathrm{BM}$ and $\mathrm{BI}$, main $=\mathrm{MM}$ and $\mathrm{MI})$ and 2 treatments for each side (island $=\mathrm{BI}$ and MI, mainland $=\mathrm{BM}$ and $\mathrm{MM})$. Each treatment encompassed the entire length of the associated island. To maintain consistency across islands, the width of each treatment was approximately half the width of the associated back channel $(\bar{x}=54.27 \mathrm{~m}, \mathrm{SE}=9.74)$. Additional open water and terrestrial areas were examined as necessary to complete the surveys. For instance, anurans believed to be calling from wetlands $\leq 250 \mathrm{~m}$ away from the river channel were included in the surveys. Waterbirds $\leq 10 \mathrm{~m}$ from the edge of a treatment were considered as occurring in that 
treatment. In addition, waterbirds occurring farther from the main channel shorelines than the treatments encompassed were noted and included in analyses of waterbird frequency (no. birds/km of shoreline) by channel.

\section{Waterbird Surveys}

Counts of all conspicuous waterbirds (divers, grebes, cormorants, waterfowl, herons, coots, gulls and terns, sandpipers and associates, and belted kingfishers; Weller 1999) in each treatment were made from a boat traveling just above idle speed parallel to and $\sim 10 \mathrm{~m}$ from shore. Individual waterbirds were identified to species, age-class, and sex if possible, and their distance from shore estimated to the nearest $10-\mathrm{m}$. Waterbirds observed on shore but $\leq 10 \mathrm{~m}$ from the water's edge were counted as occurring in the associated treatment. Waterbirds occurring farther from the main channel shorelines than the MM or MI treatments encompassed (half the width of the associated back channel) were recorded during the surveys but excluded from analyses involving area. This was so all measures of waterbird density (no. birds/ha) would be based on consistent treatment areas across each island. Domestic hybrids and domestic waterbirds were not counted in the surveys. Prior to each survey, the date, time, temperature, and weather conditions were recorded.

In 2001, waterbird surveys were conducted once in the spring (21 March-7 April), twice in the summer (14-28 May, 11-27 June), and once in the fall (10-16 November). In 2002, surveys were conducted once in the winter (26-28 January), once in the spring (23-25 March), 3 times in the summer (16-25 May, 17-26 June, 17 July-13 August), and once in the fall (28 September-6 October). The fall, winter, and spring surveys took place at any time during daylight hours all days of the week. Summer surveys were conducted between 30 minutes 
before and 4 hours after sunrise (Gibbs \& Melvin 1993). Summer surveys were usually not conducted on Saturday or Sunday due to increased interference from recreational boating activity on those days. Nighttime waterbird surveys were not conducted due to safety concerns. Common and scientific names of birds follow American Ornithologists' Union (1998).

To address the influence motorboats (including personal watercraft) may have on waterbirds (and potentially other wildlife) in my study area, the number/hour observed on the back and main channels during the waterbird surveys was recorded. Also, the number of barge tows ( $\geq 1$ barge pushed by a tow boat; hereafter, barge)/hour observed on the main channel during the waterbird surveys also was recorded. Barges are prohibited from traveling on the back channels. The entire main channel areas associated with the islands were included in these surveys. To account for potential seasonal differences, boat and barge traffic were calculated separately for summer than the other seasons.

\section{Anuran Surveys}

Call count surveys were conducted for all anuran species. The protocol was based on standard techniques established by the USFWS for the North American Amphibian Monitoring Program (Patuxent Wildlife Research Center 2003). These surveys were conducted from a boat at 2-5 fixed stations along the shoreline of each treatment. Stations were $>250 \mathrm{~m}$ from the ends of each treatment with the first station placed randomly and the remaining stations at 500-m intervals. The survey area was a 250-m radius around each station, incorporating open water and terrestrial areas. Anurans heard calling $>250 \mathrm{~m}$ from a station were excluded from analyses.

Surveys began $\sim 30$ minutes after sunset. During the surveys, I would stop at the designated station, turn the boat's motor off, and wait quietly for 1 minute. I would then listen 
for a period of 3 minutes. Any frogs or toads heard calling were recorded to species along with a call index value (CIV) for that species (Mossman 1994; Patuxent Wildlife Research Center 2003). A value of 0 indicated that no individuals of that species were heard. A value of 1 indicated that calling individuals could be counted and there were no overlapping calls. A value of 2 indicated that calls could be distinguished but there was some overlap. A value of 3 indicated a full chorus with continuous calling and overlapping calls. For values of 1 or 2 , the number of calling individuals was estimated. The date, time, temperature, and weather conditions were recorded before each survey.

Surveys were conducted 3 times each year in 2001 and 2002. The timing of each survey was dependent on temperature (period $1: \geq 5.6^{\circ} \mathrm{C}$, period $2: \geq 10{ }^{\circ} \mathrm{C}$, period $3: \geq 12.8^{\circ} \mathrm{C}$; Patuxent Wildlife Research Center 2003) and overall weather conditions. Surveys were not conducted during strong winds and were usually not conducted when rain or fog limited visibility. Survey period 1 occurred from 30 March-11 April 2001 and 24 March-15 April 2002. Period 2 occurred from 1-17 May 2001 and 16-25 May 2002. Period 3 occurred from 9-21 July 2001 and 22-27 June 2002. Common and scientific names of anurans and turtles follow Crother (2000).

\section{Turtle trapping}

Turtle trapping was conducted once in fall 2001 (23 September-14 October), three times in summer 2002 (11-23 June, 12-24 July [9 islands], 13 August [1 island], 25 July-14 August), and once in fall 2002 (5-14 October). Turtles were captured using commercially available nylon hoop nets (1.5-m long $\times$ 0.9-m diameter) with 5-cm mesh (Memphis Net and Twine Company, Inc., Memphis, Tennessee, USA). Traps were baited each day with chopped fish (canned or frozen) contained in nylon mesh bags and suspended from the center hoop of each trap. Two 
traps were set along each treatment in areas considered suitable for turtles, such as sand or gravel bars, areas of emergent vegetation, or areas of woody debris (Ernst et al. 1994). Locations were changed each trapping period to maximize the potential to encounter new turtles. Traps were set for 1 night before being moved. A trap-night was considered as 1 trap found completely intact the day after being set. A trap found with a hole torn in it $\leq 18 \mathrm{~cm}$ in diameter was counted as 0.5 trap-night, since the potential to capture large turtles (>18-cm carapace width) remained. Missing traps, those found to be collapsed, or those with holes $>18 \mathrm{~cm}$ were counted as 0 trapnights.

All captured turtles were identified to species, weighed, measured, sexed, and aged if possible (see Ernst et al. 1994), and released at the capture site. Calipers were used to measure carapace length and width to the nearest 0.1 centimeter. A Pesola spring scale was used to determine mass of individuals $\leq 5 \mathrm{~kg}$. A scale capable of weighing individuals $>5 \mathrm{~kg}$ was occasionally available in 2002. If large enough to do so without injury to the turtle, hard-shelled turtles were individually marked by notching marginal scutes with a file (Cagle 1939). Softshell turtles were marked along the edge of the carapace using a leather punch (Breckenridge 1955).

\section{Beaver and muskrat surveys}

Beaver and muskrat relative abundances in each treatment were based on direct observation or the observation of appropriate sign (i.e., tracks, scat, cuttings, middens, burrows, lodges, food caches, etc.). I first established transects along each treatment running perpendicular to shore and spaced at 250-m intervals. An equal number of transects were established per treatment across each island. Appropriate sign was searched for within a $15-\mathrm{m}$ zone to each side of a transect. Direct observations of either species within that zone were counted the same as 
observation of appropriate sign for that species. Each treatment was examined once for appropriate sign during the course of this study. Direct observations of either species were counted as they occurred. Common and scientific names of mammals follow Jones et al. (1997).

\section{Land cover evaluation}

The islands in my study area were largely undeveloped and will likely become increasingly forested in the future due to natural succession and restoration work by the USFWS. Conversely, urban development is increasing on the mainland sides. To address the influence that current land cover along the mainland shorelines may have on wildlife using the river, I examined current land use/land cover maps for West Virginia and Ohio with a Geographic Information System (ArcView, hereafter GIS; ESRI 1994; U. S. Geological Survey 2002). These maps were part of the West Virginia Gap Analysis Program (WV-GAP) and were based on a 1:100,000 scale. The map cell size was 0.09 ha. I first created buffer zones extending 300 $\mathrm{m}$ from the shorelines of the BM and MM treatments. I believed that a zone $300 \mathrm{~m}$ wide addressed most terrestrial needs of the species in my study (Burke \& Gibbons 1995; Semlitsch 2002). Next, I used the histogram tool to determine the number of cells of each cover type within the buffer zones. I used that information to determine the area and percent of each cover type within those zones (Appendix B). To standardize the many different cover types designated by WV-GAP, I grouped them into 6 types: barren land-mining/construction, forest, pasture/grassland, row crops/agriculture, urban/developed, and wetland. I then determined the percent of each of these types within the buffer zones of the BM and MM treatments. 


\section{Analyses}

\section{Waterbirds}

For all waterbirds, waterfowl (ducks and geese), and wading birds (herons, sandpipers, and killdeer [Charadrius vociferus]), density (no./ha of treatment area) and frequency (no./km of treatment shoreline) were calculated as measures of relative abundance for each treatment. Frequency was measured because of the linear nature of the river and the fact that most waterbirds observed were $\leq 5 \mathrm{~m}$ from shore. Density was measured due to the present state of the river as a series of connected lakes rather than a free-flowing system (Frost \& Mitsch 1989). The relative abundances of the most abundant species ( $>200$ total individuals observed across $>60 \%$ of the treatments) also were calculated. Waterbirds occurring farther from the main channel shorelines than the MM or MI treatments encompassed (half the width of the associated back channel) were recorded during the surveys but excluded from density analyses (see Methods). Additionally, side effects (island or mainland) involving those individuals were not considered because it could not be determined with accuracy if they were actually selecting 1 side over another. To avoid double counting observations from the multiple summer periods, the period with the maximum number of individuals of each species observed per year was used in the analyses.

Waterbird richness was calculated as the number of species found in each treatment during each season. Waterbird diversity was measured for each treatment using the Shannon Index (Shannon \& Weaver 1949). In addition, Sorenson's quantitative index of diversity was calculated for back and main channels to determine community similarity (Bray \& Curtis 1957). This measure included those individuals occurring farther from the main channel shorelines than 
the MM or MI treatments encompassed. This is a measure of similarity in species composition between 2 areas taking into account species richness and abundance. A value close to 1 indicates a high similarity (Magurran 1988: 94-95).

Waterbird relative abundance, richness, and diversity (dependent variables) were tested with 2 complete block design analyses of variance (ANOVA). One ANOVA used treatment (BI, BM, MI, and MM), year, season, and their interactions as independent variables. The second ANOVA evaluated channel $($ back $=\mathrm{BI}$ and $\mathrm{BM}$, main $=\mathrm{MI}$ and $\mathrm{MM})$, side $($ island $=\mathrm{BI}$ and $\mathrm{MI}$, mainland $=\mathrm{BM}$ and $\mathrm{MM}$ ), year, season, and their interactions as independent variables. I used 2 separate ANOVAs because I wanted to evaluate channel separately, because determining channel differences was the primary interest of the WVDNR. Island was used as a blocking factor in all waterbird analyses to remove the effects of the inherent differences between individual islands. Analyses were calculated using SAS (SAS Institute 1990). Fisher's Least Significance Difference (LSD) test was used for mean separation of treatments. An alpha level of 0.05 was used for all tests. I transformed data as necessary to meet normality and homogenous variance assumptions. Waterbird density and frequency were log transformed. Waterbird diversity and richness were not transformed. To simplify the presentation, only waterbird frequency is presented as a measure of relative abundance for that taxon in the text. Results of waterbird density are presented in Appendices C-E and G. Furthermore, effects presented for all dependent variables relate to channel (back and main) and treatment (BI, BM, MI, MM). Effects related to side (island and mainland) are presented in Appendices C, G, and IK. Waterbird frequency taking into account those individuals observed farther from shore than the MI and MM treatments encompassed is presented in Appendix F. Tests for interactions are presented in Appendices L and M. Presented means and standard errors are untransformed to 
ease interpretation.

A complete block design ANOVA was used to test wood duck brood density (no./ha) and frequency (no./km; dependent variables) between channels, sides, years, and their interactions (independent variables), in which the effects of the islands were blocked. A separate complete block design ANOVA was used to test brood density and frequency between treatments, years, and their interaction. A complete block design ANOVA also was used to test brood size (no. ducklings/brood; dependent variable) of all broods observed (all age classes) during this study between channels, in which the effects of the islands were blocked. Brood data were log transformed. An alpha level of 0.05 was used for these tests.

A complete block design ANOVA was used to test for effects between boat frequency (dependent variable) and channel, season, and their interactions (independent variables), in which the effects of the islands were blocked. A separate complete block design ANOVA was used to test for effects between barge frequency (dependent variable) and season (summer vs. other; independent variable), in which the effects of the islands were blocked. Boat and barge data were log transformed for these analyses.

\section{Anurans}

Anuran relative abundance was calculated as the frequency (based on number) of survey stations at which anurans were heard calling. Due to few observations of anurans using the island sides (BI and MI treatments), I tested only for channel effects. Anuran richness was calculated as the number of species found in each channel.

Anuran relative abundance data were log transformed to meet ANOVA assumptions. A complete block design ANOVA was used to test anuran relative abundance (dependent variable) 
against channels, years, periods, and their interactions (independent variables), in which the effects of the islands were blocked. The Least Squares Means test was used for mean separation of anuran relative abundance by survey period. An alpha level of 0.05 was used. Due to difficulty meeting ANOVA assumptions, logistic regression was used to test total anuran richness (dependent variable) between channels, years, and their interaction (independent variables). In that analysis, island could not be fit into the model as a block. Logistic regression also was used to examine the distribution of anuran CIVs (dependent variable) between channels (independent variable) for the most abundant species (i.e., those species occurring at $>25 \%$ of the survey stations). In that analysis, island $\times$ year $\times$ side $\times$ period was used as the blocking factor.

\section{Turtles}

I calculated relative abundance of all turtles and of the most abundant species $(>20$ individuals captured) as the number of turtles captured/trap-night for each treatment (BI, BM, MI, and MM). A complete block design ANOVA was used to test turtle relative abundance (dependent variable) against channels, sides, seasons, and their interactions (independent variables), in which the effects of the islands were blocked. A second ANOVA was used to test relative abundance against treatments, seasons, and their interactions (independent variables). The alpha level was 0.05 for all turtle analyses. Relative abundance data were log transformed. Fisher's LSD test was used for mean separation of treatments.

Due to few species captured, total turtle richness (no. species) and diversity (Shannon \& Weaver 1949) were calculated only for the channels. In addition, Sorenson's quantitative index of similarity was calculated for the channels (Bray \& Curtis 1957). A complete block design ANOVA was used to test turtle diversity (dependent variable) between channels (independent 
variable), blocking for the effects of the islands. Diversity data were not transformed. Due to the small sample size, logistic regression was used to test turtle richness (dependent variable) between channels, trapping period, and their interaction (independent variables), without blocking for the effects of the islands. Recaptures were excluded from all analyses.

\section{Beaver and muskrat}

The relative abundances of beavers and muskrat were calculated as the frequency of transects on which each species was detected throughout the duration of this study. A complete block design ANOVA was used to compare beaver and muskrat relative abundances (dependent variables) between channels and sides (independent variables), in which the effects of the islands were blocked. A second ANOVA was used to compare beaver and muskrat relative abundance between treatments. Fisher's LSD test was used for mean separation of treatments. The alpha level was 0.05 . Beaver data were log transformed and muskrat data were power transformed.

\section{Land cover}

I used a complete block design ANOVA to compare the percent of each of the 6 cover types (dependent variables) between the BM and MM treatment shorelines (independent variables), in which the effects of the islands were blocked. I did not test cover type areas due to differences in buffer zone size across identical islands. The alpha level was 0.05 . Row crop/agriculture and barren land cover type data were log transformed. Data for the other cover types were untransformed. 


\section{Results}

\section{Waterbird Surveys}

During the 2 years of this study, 27 different species of waterbirds were identified during the waterbird surveys (the 2 species of scaup [Aythya spp.] were not distinguished from one another and were counted as 1 species; Appendices H and I). On the back channel, I counted 2,367 individuals of 22 species $(B I=1,114$ individuals of 20 species; $B M=1,253$ individuals of 18 species). On the main channel, I counted 1,771 individuals of 22 species (MI $=724$ individuals of 20 species; $\mathrm{MM}=1,047$ individuals of 16 species). The most abundant waterbird species encountered were belted kingfisher, Canada goose (Branta canadensis), great blue heron (Ardea herodias), mallard (Anas platyrhynchos), and wood duck.

Total waterbird frequency was greater on the back channel than the main channel (Table 1). However, frequency was similar between treatments (Table 2). There were no channel, side, or treatment interactions with year $(F \leq 2.83, P \geq 0.101$; Appendix L). There also were no channel or treatment interactions with season $(F \leq 1.81, P \geq 0.147)$. There were side interactions with season $\left(F_{3,180} \geq 3.03, P \leq 0.031\right)$.

Total richness was similar between channels (Table 1). Total richness for treatments differed during the spring, with the BI treatment being greater than the BM, MI, or MM treatments (Table 2). There were no channel, side, or treatment interactions with year $(F \leq 2.20$, $P \geq 0.147$; Appendix L). There were no channel or side interactions with season $(F \leq 2.64, P \geq$ 0.051). However, there was a treatment $\times$ season interaction $\left(F_{9,180}=2.31, P=0.018\right)$.

Total waterbird diversity was similar between channels, and treatments (Tables 1 and 2). Sorenson's similarity index between back and main channels was 0.72 for 2001 and 2002. There 
were no channel, side, or treatment interactions with year $(F \leq 1.56, P \geq 0.220)$ or season $(F \leq$ 1.93, $P \geq 0.126$; Appendix L).

Total waterfowl frequency was greater on the back channel than main channel (Table 1). Frequency also was greater on the BI and BM treatments than the MI and MM treatments (Table 2). Waterfowl density and frequency showed no channel, side, or treatment interactions with year $(F \leq 2.24, P \geq 0.143)$ or season $(F \leq 2.59, P \geq 0.054$; Appendix L).

Total wading bird frequency was similar between channels (Table 1). In the spring, wading bird frequency was greater on the BI treatment than the BM or MM treatments (Table 2). During the fall, frequency was greater on the MM than BI treatment. During the winter, frequency was greater on the BI than the BM or MI treatments. Wading bird density and frequency showed no channel, side, or treatment interactions with year $(F \leq 0.75, P \geq 0.392$; Appendix L). There also were no channel $\times$ season interactions $(F \leq 0.78, P \geq 0.505)$. However, there were side and treatment interactions with season $(F \geq 2.37, P \leq 0.015)$.

Belted kingfisher frequency was greater on the main channel than back channel during the summer (Table 1). Total kingfisher frequency was greater on the MM treatment than the BI, BM, or MI treatments (Table 2). Belted kingfisher density and frequency showed no channel, side, or treatment interactions with year $(F \leq 2.76, P \geq 0.105$; Appendix L). There also were no side or treatment interactions with season $(F \leq 1.45, P \geq 0.171)$. There was no channel $\times$ season interaction with density $\left(F_{3,188}=2.60, P=0.054\right)$, though there was an interaction with frequency $\left(F_{3,188}=3.12, P=0.027\right)$.

Canada goose frequency was similar among channels and treatments for all seasons (Tables 1 and 2). No Canada geese were observed during the fall 2001 survey. There were no 
channel, side, or treatment interactions with year $(F \leq 2.17, P \geq 0.149$; Appendix L). There also were no side or treatment interactions with season $(F \leq 1.53, P \geq 0.140)$. However, there were channel interactions with season $\left(F_{3,188} \geq 2.89, P \leq 0.037\right)$.

Total great blue heron frequency was similar between back and main channels (Table 1). However, heron frequency was greater on the BI than BM, MI, and MM treatments (Table 2). Great blue heron density and frequency showed no interactions with year $(F \leq 0.88, P \geq 0.355)$ or season $(F \leq 2.11, P \geq 0.100$; Appendix L).

Mallard frequency was greater on the back channel than main channel during the spring and winter (Table 1). In addition, frequency was greater on the BI than BM and MI treatments during the spring, and greater on the $\mathrm{BM}$ than $\mathrm{MI}$ and $\mathrm{MM}$ treatments during the winter (Table 2). Mallard density and frequency showed no channel, side, or treatment interactions with year ( $F \leq 0.58, P \geq 0.634$; Appendix L). There also were no side interactions with season $\left(F_{3,188} \leq\right.$ $0.74, P \geq 0.528)$. However, there were channel and treatment interactions with season $(F \geq 3.78$, $P \leq 0.012)$.

Total wood duck frequency was greater on the back channel than main channel (Table 1), and greater on the $\mathrm{BI}$ treatment than the $\mathrm{BM}, \mathrm{MI}$, or MM treatments (Table 2). There were no wood ducks observed during the winter survey period. Wood duck density and frequency showed no channel, side, or treatment interactions with year $(F \leq 0.19, P \geq 0.670)$ or season $(F \leq$ 2.15, $P \geq 0.095$; Appendix L).

Wood duck broods were observed during the waterbird surveys in large enough numbers and wide enough distribution for analyses. Wood duck brood frequency (broods $/ \mathrm{km}$ ) was greater on the back $(\bar{x}=0.05, \mathrm{SE}=0.01)$ than main $(\bar{x}=0.02, \mathrm{SE}=0.01)$ channel $\left(F_{1,27}=15.47, P<\right.$ 
$0.001)$, and greater on the $\mathrm{BI}(\bar{x}=0.06, \mathrm{SE}=0.02)$ and $\mathrm{BM}(\bar{x}=0.05, \mathrm{SE}=0.02)$ than $\mathrm{MM}(\bar{x}$ $=0.002, \mathrm{SE}=0.002)$ treatments $\left(F_{3,27}=5.86, P=0.003\right)$. The $\mathrm{BM}$ and $\mathrm{MI}(\bar{x}=0.03, \mathrm{SE}=$ 0.02) treatments were similar. Wood duck brood density (broods/ha) also was greater on the back $(\bar{x}=0.01, \mathrm{SE}=0.004)$ than main $(\bar{x}=0.004, \mathrm{SE}=0.003)$ channel $\left(F_{1,27}=17.28, P<\right.$ $0.001)$, and greater on the $\mathrm{BI}(\bar{x}=0.02, \mathrm{SE}=0.006)$ and $\mathrm{BM}(\bar{x}=0.01, \mathrm{SE}=0.004)$ than $\mathrm{MI}(\bar{x}$ $=0.01, \mathrm{SE}=0.01)$ and $\mathrm{MM}(\bar{x}=0.0002, \mathrm{SE}=0.0002)$ treatments $\left(F_{3,27}=6.22, P=0.002\right)$.

There were no channel, side, or treatment interactions with year $(F \leq 0.13, P \geq 0.945$; Appendix L). Average brood size of all age classes totaled was similar between the back $(\bar{x}=3.68$ ducklings/brood, $\mathrm{SE}=0.38 ; n=31)$ channel and the main $(\bar{x}=3.00, \mathrm{SE}=0.77 ; n=6)$ channel $\left(F_{1,27}=0.01, P=0.926\right)$.

Total boat traffic (e.g., recreational motorboats and personal water craft) during the waterbird surveys was greater on the main $(\bar{x}=0.84$ boats $/ \mathrm{hr}, \mathrm{SE}=0.21)$ channel than the back $(\bar{x}=0.09, \mathrm{SE}=0.05)$ channel $\left(F_{1,27}=10.64, P=0.003\right)$. Total barge traffic on the main channel averaged 0.56 barges/hr $(\mathrm{SE}=0.12)$. Boat traffic was similar between seasons $\left(F_{1,27}=\right.$ $0.59, P=0.450)$. Boat traffic showed no channel interaction with season $\left(F_{1,27}=0.58, P=\right.$ 0.453). Barge traffic also was similar between seasons $\left(F_{1,9}=2.33, P=0.161\right)$.

\section{Anuran Surveys}

I detected 5 species during the anuran surveys: spring peeper (Pseudacris crucifer), American toad (Bufo americanus), Fowler's toad (B. fowleri), Cope's gray treefrog (hereafter gray treefrog; Hyla chrysoscelis), and mountain chorus frog (Pseudacris brachyphona). Anuran relative abundance was greater on the back channel than main channel during the first survey period 
(Table 3). Total anuran richness was greater on the back $(\bar{x}=0.85, \mathrm{SE}=0.11)$ channel than the main $(\bar{x}=0.47, \mathrm{SE}=0.09)$ channel $\left(X^{2}{ }_{1}=6.84, P=0.009\right)$. Anuran relative abundance showed no channel $\times$ year interaction $\left(F_{1,72}=0.17, P=0.682\right)$. There was a channel $\times$ period interaction $\left(F_{2,72}=6.97, P=0.002\right)$. Anuran richness showed no channel interaction with year $\left(X^{2}{ }_{1}=0.09\right.$, $P=0.764)$.

Due to few observations of Fowler's toads and mountain chorus frogs, logistic regression of CIVs could only be completed for spring peepers, American toads, and gray treefrogs (Table 4). Distribution of CIVs was different for spring peepers. For that species in general, the back channels had a smaller percentage of call index values of 0 and a larger percentage of values of 2 and 3 than the main channel. Of the 2 additional species encountered during the surveys, mountain chorus frogs only occurred at 1 survey station on the back channel, and 3 stations on the main channel, each time with a call index value of 2 . Fowler's toads occurred at 2 survey stations on the back channel, both times with a call index value of 1 .

\section{Turtle trapping}

During the 5 periods of turtle trapping, I completed a total of 376 trap-nights $(\bar{x}=75.10, \mathrm{SE}=$ 2.49), captured 84 turtles, and recaptured 2. Species caught were painted turtle (Chrysemys picta), smooth softshell (Apalone mutica), snapping turtle, spiny softshell, and stinkpot (Sternotherus odoratus). Turtle abundance was greater on the back channel than the main channel during the fall (Table 5). Also during the fall, abundance was greater on the BI treatment than the MI or MM treatments (Table 6). For all turtles captured, there were no channel, side, or treatment interactions with the 3 summer periods $(F \leq 2.04, P \geq 0.138)$ or the 2 
fall periods $(F \leq 1.11, P \geq 0.299$; Appendix $\mathrm{K})$. With all seasons combined, there was no side $\times$ season interaction $\left(F_{1,36}=0.18, P=0.676\right)$. However, there were channel and treatment interactions with season $(F \geq 3.78, P \leq 0.019)$.

Turtle richness was greater on the back $(\bar{x}=0.60, \mathrm{SE}=0.10)$ than main $(\bar{x}=0.53, \mathrm{SE}=$ $0.11)$ channel $\left(X^{2}{ }_{1}=3.84, P=0.050\right)$. Richness showed no channel interaction with trapping period $\left(X^{2}{ }_{4}=4.16, P=0.385\right)$. Total turtle diversity was similar between the back $(\bar{x}=0.27, \mathrm{SE}$ $=0.03)$ and main $(\bar{x}=0.14, \mathrm{SE}=0.04)$ channel $\left(F_{1,8}=4.30, P=0.072\right)$. Sorenson's similarity index between the back and main channel was 0.28 .

Only snapping turtles $(n=39)$ and spiny softshells $(n=38)$ occurred in numbers large enough to analyze separately. Total snapping turtle abundance was greater on the back channel than the main channel (Table 5), and greater on the $\mathrm{BI}$ and $\mathrm{BM}$ treatments than the MI and MM treatments (Table 6). For both species, there were no channel, side, or treatment interactions with the multiple summer periods $(F \leq 2.09, P \geq 0.131)$ or fall periods $(F \leq 2.94, P \geq 0.095$; Appendix K). For the snapping turtle, there were no channel, side, or treatment interactions with season ( $F \leq 2.24, P \geq 0.143)$. During the summer, spiny softshells were more abundant on the main channel than the back channel (Table 5), and more abundant on the MI and MM treatments than the BI and BM treatments (Table 6). For spiny softshells, there was no side $\times$ season interaction $\left(F_{1,36}=1.59, P=0.216\right)$. However, there were channel and treatment interactions with season $(F \geq 4.15, P \leq 0.013)$. Of the other 3 species encountered during trapping efforts, a single smooth softshell occurred once on a MM treatment. Painted turtles and stinkpots were encountered on back channels 2 and 4 times, respectively. 


\section{Beaver and muskrat surveys}

Total beaver relative abundance was greater on the back $(\bar{x}=0.82, \mathrm{SE}=0.04)$ than main $(\bar{x}=$ $0.53, \mathrm{SE}=0.05)$ channel $\left(F_{1,27}=21.90, P<0.001\right)$, and greater on the $\mathrm{BI}(\bar{x}=0.87, \mathrm{SE}=0.04)$ treatment, than the MI $(\bar{x}=0.61, \mathrm{SE}=0.09)$ and $\mathrm{MM}(\bar{x}=0.46, \mathrm{SE}=0.05)$ treatments $\left(F_{3,27}=\right.$ 8.72, $P<0.001)$. Abundance on the $\mathrm{BM}(\bar{x}=0.27, \mathrm{SE}=0.03)$ treatment was similar to the MI but greater than the MM treatment.

Total muskrat relative abundance was greater on the back $(\bar{x}=0.68, \mathrm{SE}=0.05)$ than main $(\bar{x}=0.19, \mathrm{SE}=0.04)$ channel $\left(F_{1,27}=48.50, P<0.001\right)$, and greater on the $\mathrm{BI}(\bar{x}=0.79$, $\mathrm{SE}=0.04)$ than the $\mathrm{BM}(\bar{x}=0.56, \mathrm{SE}=0.08), \mathrm{MI}(\bar{x}=0.20, \mathrm{SE}=0.07)$, and $\mathrm{MM}(\bar{x}=0.19$, $\mathrm{SE}=0.06)$ treatments $\left(F_{3,27}=17.96, P<0.001\right)$. Abundance on the BM treatment also was greater than the MI and MM treatments.

\section{Land cover}

The percent coverage of forest, pasture/grassland, row crop/agriculture, and urban/developed areas was similar between $\mathrm{BM}$ and $\mathrm{MM}$ treatment shorelines $\left(F_{1,9} \leq 1.29, P \geq 0.285\right.$; Table 7$)$. The percent coverage of barren land and wetland areas was greater on the MM than BM treatment shorelines $\left(F_{1,9} \geq 5.31, P \leq 0.047\right)$.

\section{Discussion}

\section{Waterbirds}

This study confirms the importance of Ohio River island back channels for waterbird species requiring abundant cover, such as mallards and wood ducks. Mallards were, on average, $>3$ 
times more abundant on the back channel than main channel. Furthermore, the BI treatment had $>4$ times the abundance than the MI treatment. Wood ducks were twice as abundant on the back channel than main channel, and 6 times more abundant on the BI than MI treatments. The back channel also had $>3$ times the amount of cover, in the form of woody debris and overhanging branches, than the main channel (see Chapter 3).

The importance of slow river channels capable of supporting woody cover for wood ducks is commonly recognized. Cottrell et al. (1990), in a Tennessee study, found that portions of streams with wooded shorelines and fallen trees were 2 features that determined use of areas by Class I ducklings. Similarly, Minser (1993) found that wood duck brood density (no./km) was positively correlated with woody debris in the water and large overhanging trees. In general, woody overhead cover is considered an essential component of good brood habitat (Webster \& McGilvrey 1966). Sacilotto (2002) found that the back channel sides of the Ohio River islands provided more tree cavities for cavity-nesting birds, such as wood ducks, than the main channel sides. I found that all wood duck brood classes preferred the back channel, and in particular the BI treatment.

An incidental observation was made during my study of a female wood duck and Class I brood moving across the entire width of the Ohio River ( $\sim 450 \mathrm{~m}$ of open water) from the main channel towards a back channel. This type of movement is not unusual, as females may lead broods considerable distances in search of quality brood habitat (Hepp \& Hair 1977; DiGiulio \& Hamilton 1979; Smith \& Flake 1985), and provides further evidence of the importance of island back channels for brood-rearing.

Characteristics of nonbreeding habitat for wood ducks are considered similar to high quality brood habitat (Gilmer et al. 1977; McGilvrey 1968; Haramis 1990). However, in the case 
of the Ohio River, and probably large channelized rivers in general, the open water and fast current limits overall use by this species compared to palustrine and scrub/shrub wetland types (sensu Cowardin et al. 1979; Minser 1993). In addition, although the back channels supported more wood ducks than the main channel during all seasons, studies have found that, during autumn at least, rivers may only be utilized as travel lanes (Hepp \& Hair 1977; Smith \& Flake 1985). In my study, wood duck abundance decreased from a summer back channel mean of 2.49 birds $/ \mathrm{km}(\mathrm{SE}=0.41)$ to a late fall mean of $0.28(\mathrm{SE}=0.18)$, to 0 birds in winter.

The main channel was found to be more important for belted kingfishers than back channels, with almost twice the abundance. Furthermore, the MM treatment had more than twice the abundance of belted kingfishers than the BI treatment. The large amount of open water on the main channel likely provided increased foraging opportunities for this species than the back channels. Researchers have found that narrow streams completely shaded by vegetation, with overgrown shorelines, or with the water surface obstructed by debris, are generally avoided by belted kingfishers (White 1953; Imhof 1962; Prose 1985). Riffle areas also are important for foraging by this species (Brooks \& Davis 1987). The few riffles observed on my study area occurred on the MM treatments.

The main channel also likely benefits belted kingfishers by providing nesting sites, which are high, steep soil banks devoid of any vegetation. The strong current and wave action on the main channel has exposed many potential nesting banks, particularly along the MI treatments. Belted kingfishers require these areas for constructing nesting burrows (Cornwell 1963; Hamas 1974). Brooks and Davis (1987) found that the availability of nesting banks strongly influenced the location of breeding territories along streams. Although a sign of increasing shoreline erosion, these banks likely contributed to the abundance of belted kingfishers on the main 
channel.

Average great blue heron abundance was greatest on the BI treatment, with more than twice the birds observed than the MI treatment, and $>3$ times the abundance of the BM and MM treatments. This reflects the importance of the islands in combination with the back channels for this species and, likely, similar species (e.g., green heron). The islands in general appeared to provide a variety of foraging areas for great blue herons, such as sloughs, mudflats, sandbars, and forested wetlands (Kushlan 1978; Thompson 1979; Butler 1992). However, the slow current (relative to the main channel) and thickly wooded shorelines of the back channels (particularly the BI treatments) likely provided additional food resources. In addition, the narrowness of the back channels and the location of most of them, off to one side of the river, also provided cover from potential human disturbances, such as boats on the main channel and human activities on the mainland. Protection from boat activities was most apparent along the BI treatments due to those areas facing away from the open water of the main channel. Although great blue herons generally are not considered as requiring concealment while foraging, they usually prefer areas free from human disturbance (Short \& Cooper 1985). The results of this study suggest that the back channels improve the inherent isolation from human activities provided by the islands.

The overall abundance of great blue herons on the islands can partially be attributed to the presence of active colonies. All great blue heron colonies observed within the study area occurred on islands. The attractiveness of islands as colony sites primarily stems from the great blue heron's preference for isolation during nesting (Short \& Cooper 1985; Gibbs et al. 1987). In a study of great blue heron colonies in the lower Chesapeake Bay of Virginia, it was found that active colonies were situated farther from human structures than randomly located sites (Watts \& Bradshaw 1994). 
Total boat traffic observed during this study was $>9$ times greater on the main channel than back channel. In addition, all barge activity occurred on the main channel. The waterbird abundance observed on back channels likely was influenced by the protection provided by these areas from boat and barge activities. Disturbance to waterbirds caused by boating activity has been found to be greater, based on flush distance, than disturbances by barges or shore activities (Havera et al. 1992). The narrowness and location of most Ohio River island back channels appeared to limit use of these areas by boaters navigating large craft or pulling water-skiers. However, back channels appeared to be more susceptible to the affects of boat wakes due to their narrowness. Havera et al. (1992) suggested that areas off-limits to boating be created, particularly during spring and fall migration, to minimize disturbance to waterfowl.

\section{Anurans}

Little information is known about anurans inhabiting large river systems. On the Ohio River, the USFWS notes that anurans and turtles in particular have not been well studied, with only county presence or absence data available (USFWS 2002). Although all anuran species encountered in this study have previously been documented on the ORINWR (USFWS 2002), the greater abundance of anurans that I found on back channels during the first survey period, and the overall greater anuran richness, are evidence of the importance of back channels for this wildlife group.

However, of the 5 species encountered during the surveys, 2 of them, spring peepers and mountain chorus frogs, are not known to exist with predatory fish (Kats et al. 1988). Therefore, it is unlikely they were actually calling from the river itself. Rather, they were probably using small temporary wetlands located away from the river channel but within aural distance of the 
researchers. The relationship between back channel characteristics and these small wetlands is important in understanding large riverine systems. A mosaic of wetland types, especially if maintained by an annual flooding regime, will result in maximized productivity and diversity of a floodplain (Bayley 1995; Johnson et al. 1995; Galat et al. 1998). In my evaluation of the different land cover types along the mainland sides, I found that the MM treatment shorelines had more areas of wetland than the BM shorelines. However, the large scale of the land use/land cover maps used for the evaluation did not account for wetlands $<0.09$ ha in size. There were numerous small wetlands on the BM sides that were not accounted for in the GIS analysis. Evaluating all wetlands in the vicinity of the study area for anuran use was beyond the scope of this project.

Two other species observed during the anuran surveys, American toads and gray treefrogs, possess antipredator defenses and did possibly use the river, at least during the breeding season. American toads have eggs, larvae, and adults that are toxic to fish (Voris \& Bacon 1966; Licht 1968; Petranka et al. 1987). It is assumed Fowler's toads possess defenses similar to American toads, and so also may have used the river. Gray treefrog larvae may avoid predation due to their bright reddish orange tail fins, which might deflect attacks away from their body (Caldwell 1982; Hecnar \& M'Closkey 1997). Additionally, adult gray treefrogs have been found to alter their choice of calling and oviposition sites due to the presence of predators or competitors (Resetarits \& Wilbur 1989; 1991). Thus, although the distributions of American toads and gray treefrogs were not different between back and main channels, the results suggest back channel areas support an overall greater abundance of anurans than the main channel.

Three incidental observations of anurans during this study provide further evidence of the importance of back channels for this group. On 17 May 2001, a frog (Rana spp.) was observed 
along a mudflat on the BI treatment shore of Captina Island. Similarly, on 24 June 2002, a frog was observed among exposed tree roots on the BI treatment shore of Mill Creek Island. Finally, on 14 August 2002, at approximately 0930 hrs, a single American bullfrog (Rana catesbeiana) was heard calling from the BI treatment of Captina Island. These observations correspond to Tolin and Schettig (1983), who noted toads and ranid frogs associated with the unconsolidated shorelines of the islands and around tree roots and debris, although they did not specify back channel or main channel. Toads and aquatic frogs (e.g., American bullfrog and green frog [Rana clamitans]) may regularly inhabit back channel areas but rarely call due to the presence of predators (Resetarits \& Wilbur 1991). This would cause them to remain undetected during typical call count surveys.

In addition to the presence of predatory fish, there are other factors that likely influenced anuran use of the study area. One was an almost complete absence of vegetation in the littoral zone of the river (Chapter 3). Vegetation is an important component of anuran cover (Stratman 2000). The small areas of aquatic vegetation that did exist did not seem to appear until August and September (personal observation), well past the breeding season for most anurans in West Virginia (Green \& Pauley 1987). Another factor may be siltation due to runoff, which is known to reduce larval survival (Bridges \& Semlitsch 2002). Throughout the study area the water was rather turbid, especially after rain events. In addition, the substrate in both channels contained moderate amounts of silt that was often resuspended due to high water velocity or boat/barge activity (Chapter 3). A high current also can sweep away anuran eggs (Kupferberg 1996). Average velocity was $2.85 \mathrm{~cm} / \mathrm{sec}$ faster on the main channel than back channel (Chapter 3). The back channels likely provided some protection from high water velocity, thus being more conducive for anurans than the main channel. 


\section{Turtles}

The USFWS has described the need for more information on turtle use of the Ohio River (USFWS 2002). I believe my study fulfilled some of this need, particularly as it pertains to turtle use of island back and main channels. I found that turtles were $>4$ times more abundant on the back channel than the main channel during the fall. In addition, total turtle richness was greater on the back channel. However, distribution of the 2 most common species, spiny softshells and snapping turtles, tended to vary between channels. Both of these species have been previously documented on the ORINWR (USFWS 2002). I found spiny softshells almost exclusively on the main channel, at least during the summer. Conversely, snapping turtles were consistently more abundant on the back channel. This difference is reflected in the Sorenson's similarity index, which showed that the back and main channels were only $28 \%$ similar. This also reflects the 2 species' preferences for different habitat characteristics, and thus, the importance of conserving the heterogeneity provided by the back channels (DonnerWright et al. 1999; Bodie \& Semlitsch 2000).

Spiny softshells prefer deep, fast water containing sandbars or mud flats (Ernst et al. 1994; DonnerWright et al. 1999). The results of this study somewhat reflected this preference, with the main channel having a higher abundance of this species during the summer. Average water velocity $(\mathrm{cm} / \mathrm{sec})$ was faster on the main channel than back channel (see above). Additionally, the main channel was deeper than the back channel and contained mud or sand bottoms devoid of any debris (Chapter 3).

However, there appeared to be a shift in distribution of spiny softshells from the main channel to the back channels between the summer and fall trapping periods (Table 5). The BI 
treatment had $>6$ times the abundance of spiny softshells during the fall than during the summer. Conversely, the MM treatment had $>9$ times fewer individuals during the fall. This may be due to back channels providing higher quality winter refugia than the main channel. River turtles often escape harsh winter conditions by burying in substrate at the bottom, under overhanging banks, or under submerged woody debris (Ernst et al. 1994). The back channels clearly had more debris and overhanging banks, making these areas more conducive as overwintering sites. Also, the back channels were found to have a higher percent of silt in the substrate than the main channel (Chapter 3). A high percent of silt is thought to be of higher quality to overwintering turtles (Graves \& Anderson 1987).

Back channels are clearly more important to snapping turtles than the main channel. Snapping turtles are associated with slower waters and an abundance of submerged woody debris (Ernst et al. 1994; DonnerWright et al. 1999). This debris is used primarily as cover from which to ambush prey (Froese 1978; Ernst et al. 1994). As previously discussed, these conditions occurred more often on back channels than the main channel. The overall greater abundance of snapping turtles on the back channel was at least partially due to these characteristics.

Of the 3 additional turtle species I encountered during the trapping efforts, painted turtles and stinkpots were only found on back channels. Painted turtles are widely distributed throughout West Virginia and are known to occur on the ORINWR (Green and Pauley 1987; USFWS 2002). However, the occurrence of stinkpots in this study area is believed to be the first documented for the refuge (USFWS 2002). The occurrence of both species on back channels was likely due to their preference for shallow, slow water, and particularly with the painted turtles, abundant basking sites (Ernst et al. 1994). Their overall small numbers may be due to intolerance for fluctuating water levels and velocity, and changes in depth, which occurred at 
different times and locations throughout the study area. A similar conclusion was reached as an explanation for low numbers of western painted turtles (Chrysemys picta bellii) in the St. Croix River, Wisconsin and Minnesota, USA (DonnerWright et al. 1999). Similarly, Vandewalle and Christiansen (1996), studying turtle use of Red Rock Reservoir on the Des Moines River, Iowa, USA, suggested a correlation between highly fluctuating water levels and low turtle richness.

Smooth softshells are considered quite rare in West Virginia and were not previously known to occur on the ORINWR (Green \& Pauley 1987; USFWS 2002). The occurrence of only 1 individual on an MM treatment during my study likely reflected the intolerance this habitat specialist has for human activity and river modifications (Moll 1980; Vandewalle \& Christiansen 1996). Although this individual technically did not occur within the boundary of the refuge (which was directly across the channel), its occurrence adds to the known turtle diversity of the West Virginia portion of the Ohio River and the potential diversity of the refuge.

I had hoped that northern map turtles (Graptemys geographica) would be encountered in this study. Although not common in West Virginia (Green \& Pauley 1987), the portion of the Ohio River covered by my study area is included within the species range (Ernst et al.1994). Some references for this species described its habitat requirements as including a large body of water with a soft bottom and abundant basking sites (Green \& Pauley 1987; Ernst et al. 1994). However, other studies have found this species associated with a gravel substrate (Fuselier \& Edds 1994; DonnerWright et al. 1999). Despite seemingly abundant basking sites provided on the back channels, a lack of gravel substrate (see above; Chapter 3) might help explain this species absence from my study.

An incidental observation made during this study further reflects the value of back channels for certain turtle species. On 24 May 2002, I found a single eastern box turtle 
(Terrapene carolina) swimming along the back channel of Captina Island. Eastern box turtles are known to occur on the ORINWR (USFWS 2002). Though not a common behavior, other researchers have observed this species swimming across small waterbodies (Ernst et al. 1994). The narrowness and slow velocity of the back channels likely facilitates the movement of many wildlife species between the mainland and islands, thereby improving species and genetic diversity on the islands, as well as providing dispersal areas.

\section{Beaver and muskrat}

Beavers and muskrat clearly benefit from the slow current and dense herbaceous vegetation along the shorelines of the back channels. In riverine systems, both species require these characteristics (Errington 1963; Jenkins 1981; Howard 1985). Back channels were found to have more herbaceous vegetation (primarily knotweed) within $10 \mathrm{~m}$ of the water's edge than the main channel (Chapter 3). Beavers additionally require areas of woody vegetation primarily used as winter food (Jenkins 1979). I found that the back channels had $\sim 5 \%$ more canopy closure $\leq 100$ $m$ of the water's edge than main channel, and was greatest on the back channel sides of the islands, or BI treatments (Chapter 3). Based on the land cover evaluation, the BM treatment shorelines tended to have more forest than the MM treatment shorelines. Additionally, as previously discussed, there was an abundance of downfall and submerged woody debris on back channels. This is considered another important characteristic of riverine muskrat habitat (Errington 1937; Brooks 1980).

In addition to beavers and muskrat, American mink (hereafter mink; Mustela vison) also likely benefit from the back channels. Although I did not attempt to estimate the relative abundance of mink during this study, and no incidental observations were made, they are known 
to exist along the Ohio River (P. Morrison, USFWS, personal communication). They are commonly associated with areas of woody debris, which provide foraging cover and den sites (Melquist et al. 1981). They also will use abandoned muskrat burrows (Arnold \& Fritzell 1989). Furthermore, an increase in mink population has been correlated with an abundance of muskrat (Bulmer 1974). So, as with muskrat, it is probable that mink are more abundant on the back channels than the main channel.

\section{Conservation Implications}

Resource managers have long believed that back channels associated with islands on the Ohio River provide features critical for the habitat requirements of many wildlife species (Tolin \& Schettig 1983; USFWS 1989). However, previous to this study, there have not been any quantitative studies for most species in these areas. This study provided quantitative evidence supporting the assumption that back channels are important for several species of waterbirds and turtles, all anurans, and furbearing mammals. The narrowness of the back channels, the protection they provide from the main current of the river, and their ability to support vegetated shorelines and woody debris, appeared to be the characteristics that most benefited species in these groups.

Ohio River islands and back channels should be protected from development activities that may degrade these areas. In particular, activities that involve clearing shoreline vegetation, removing floating and submerged woody debris, and potentially causing shoreline erosion should be prohibited. Activities that could increase the amount of boat traffic in the back channels, such as the building of boat docks, should be restricted.

A primary objective of management programs in back channel areas should be to 
increase the amount of woody debris and overhanging branches, and stabilize the shorelines from further erosion. Also, backwater embayment areas containing shallow water with slow or no water current and persistent emergent vegetation should be created, or allowed to occur naturally as part of annual flooding events. This would particularly benefit wading birds and dabbling ducks (Weller 1999), certain turtle species (DonnerWright et al. 1999), and anurans (Stratman 2000). However, the presence of predatory fish will remain a factor limiting use of the river by many anurans (Semlitsch 2002).

Undeveloped terrestrial buffer zones also should be created and/or maintained. Although wildlife use of the river floodplain was not a primary focus of this study, the terrestrial nature of several of the species encountered, such as beavers, muskrat, American toads, gray treefrogs, and turtles, justifies this recommendation. Beavers may require forested areas up to $200 \mathrm{~m}$ from a wetland in order to forage (Allen 1983). River-inhabiting muskrat are believed to forage $\leq 10 \mathrm{~m}$ from the water's edge (Allen \& Hoffman 1984). In regards to anurans and turtles, several studies suggest the optimal width for buffers. Semlitsch (2002) recommends that a vegetated zone up to $200 \mathrm{~m}$ from a wetland is necessary to maintain juvenile and adult aquatic-breeding amphibians. In a Florida study, a $275 \mathrm{~m}$ terrestrial buffer zone would have been necessary to protect $100 \%$ of the nest and hibernation sites of freshwater turtles (Burke \& Gibbons 1995). It is important to note that softshell turtles, in particular, require undisturbed areas of exposed sand for nesting (Ernst et al. 1994). A zone $449 \mathrm{~m}$ wide would have encompassed $95 \%$ of movements by a population of turtles along the Missouri River (Bodie \& Semlitsch 2000).

Restricting human access to back channels is one option to minimize disturbance to wildlife. However, due to the popularity of these areas by recreational boaters, hunters, and anglers, broad spatial restrictions would be unreasonable and impossible to enforce (Steidl \& 
Anthony 1996). Therefore, temporal restrictions are probably a better option. Havera et al. (1992) suggested limiting human access to areas during spring and fall migrations. However, placing fall restrictions on areas around the ORINWR would not be supported by waterfowl hunters, who pay for refuge acquisition. In the back channels, summer would probably be a better time to limit access to back channels, particularly during morning hours, due to the presence of broods. In addition, the creation of "no-wake zones" in back channels would help decrease shoreline erosion and minimize direct disturbance to wildlife caused by boating activities.

Back channels that would most benefit from restrictions and "no-wake zones" are those that are especially long and narrow and in which I observed multiple broods, or which had the potential to support multiple broods. These back channels are associated with Buffington,

Middle, Neal, Paden, Wells, and Williamson islands (Figure 2; Appendix A).

\section{Literature Cited}

Allen, A. W. 1983. Habitat suitability index models: beaver. U. S. Fish and Wildlife Service. FWS/OBS-82/10.30.

Allen, A. W., and R. D. Hoffman. 1984. Habitat suitability index models: muskrat. U. S. Fish and Wildlife Service. FWS/OBS-82/10.46.

American Ornithologists' Union. 1998. Check-list of North American birds, Seventh edition. AOU and Allen Press, Lawrence, Kansas.

Arnold, T. W., and E. K. Fritzell. 1989. Spring and summer prey remains collected from male mink dens in southwestern Manitoba. Prairie Naturalist 21:189-192.

Bayley, P. B. 1995. Understanding large river-floodplain ecosystems. BioScience 45:153-158. 
Bodie, J. R, and R. D. Semlitsch. 2000. Spatial and temporal use of floodplain habitats by lentic and lotic species of aquatic turtles. Oecologia 122:138-146.

Braun, E. L. 1950. Deciduous forests of eastern North America. Hafner Press, MacMillion Publishing Co., New York, New York.

Bray, J. R., and C. T. Curtis. 1957. An ordination of the upland forest communities of the upland forest communities of southern Wisconsin. Ecological Monographs 27:325-349.

Breckenridge, W. J. 1955. Observations on the life history of the soft-shelled turtle Trionyx ferox, with especial reference to growth. Copeia 1955:5-9.

Bridges, C. M., and R. D. Semlitsch. 2002. Linking xenobiotics to amphibian declines. In press in M. Lannoo, editor. Status and conservation of U. S. amphibians. Volume 1. Conservation essays. In press, University of California Press, Berkeley, California.

Brooks, R. P. 1980. A model of habitat selection and population estimation for muskrats (Ondatra zibethicus) in riverine environments in Massachusetts. Ph. D. Dissertation, University of Massachusetts, Amherst, Massachusetts.

Brooks, R. P., and W. J. Davis. 1987. Habitat selection by breeding belted kingfishers (Ceryle alcyon). American Midland Naturalist 117:63-70.

Bulmer, M. G. 1974. A statistical analysis of the 10-year cycle in Canada. Journal of Animal Ecology 43:701-718.

Burke, V. J., and J. W. Gibbons. 1995. Terrestrial buffer zones and wetland conservation: a case study of freshwater turtles in a Carolina bay. Conservation Biology 9:1365-1369.

Butler, R. W. 1992. Great blue heron. In A. Poole, P. Stettenheim, and F. Gill, editors. The Birds of North America, No. 25. The Academy of Natural Sciences, Philadelphia, Pennsylvania, and The American Ornithologists' Union, Washington, D. C. 
Cagle, F. R. 1939. A system of marking turtles for future identification. Copeia 1939:170-173.

Caldwell, J. P. 1982. Disruptive selection: a tail color polymorphism in Acris tadpoles in response to differential predation. Canadian Journal of Zoology 60:2817-2818.

Cornwell, G. W. 1963. Observations on the breeding biology and behavior of a nesting population of belted kingfishers. Condor 65:426-431.

Cottrell, S. D., H. H. Prince, and P. I. Padding. 1990. Nest success, duckling survival, and brood habitat selection of wood ducks in a Tennessee riverine system. Pages 191-197 in L. H. Fredrickson, G. V. Burger, S. P. Havera, D. A. Graber, R. E. Kirby, and T. S. Taylor, editors. Proceedings of the 1988 North American Wood Duck Symposium, St. Louis, Missouri.

Cowardin, L. M., V. Carter, F. C. Golet, and E. T. LaRoe. 1979. Classification of wetlands and deepwater habitats of the United States. U. S. Fish and Wildlife Service. FWS/OBS$79 / 31$.

Crother, B. I. 2000 (2001). Scientific and standard English names of amphibians and reptiles of North America north of Mexico, with comments regarding confidence in our understanding. SSAR Herpetological Circular 29.

DiGiulio, R. T., and R. B. Hamilton. 1979. Utilization of agricultural wetlands in a Mississippi River bottomland by wood duck and hooded merganser broods. Proceedings of the Annual Conference of the Southeastern Association of Fish and Wildlife Agencies 33:8187.

DonnerWright, D. M., M. A. Bozek, J. R. Probst, and E. M. Anderson. 1999. Response of turtle assemblage to environmental gradients in the St., Croix River in Minnesota and Wisconsin, U.S.A. Canadian journal of zoology 77:989-1000. 
Ernst, C. H., R. W. Barbour, and J. E. Lovich. 1994. Turtles of the United States and Canada. Smithsonian Institution Press, Washington, D. C.

Errington, P. L. 1937. Habitat requirements of stream-dwelling muskrats. Transactions of the North American Wildlife Conference 2:411-416.

Errington, P. L. 1963. Muskrat populations. Iowa State University Press, Ames, Iowa, USA.

ESRI. 1994. ARC/INFO. Version 7.01. Environmental Systems Research Institute. Redlands, California.

Froese, A. D. 1978. Habitat preferences of the common snapping turtle Chelydra s. serpentina (Reptilia, Testudines, Chelydridae). Journal of Herpetology 12:53-58.

Frost, S. L., and W. J. Mitsch. 1989. Resource development and conservation history along the Ohio River. Ohio Journal of Science 89:143-152.

Fuselier, L., and Edds, D. 1994. Habitat partitioning among three sympatric species of map turtles, genus Graptemys. Journal of Herpetology 28:154-158.

Galat, D. L., L. H. Fredrickson, D. D. Humburg, K. J. Bataille, J. R. Bodie, J. Dohrenwend, G. T. Gelwicks, J. E. Havel, D. L. Helmers, J. B. Hooker, J. R. Jones, M. F. Knowlton, J. Kubisiak, J. Mazourek, A. C. McColpin, R. B. Renken, and R. D. Semlitsch. 1998. Flooding to restore connectivity of regulated, large-river wetlands. BioScience 48:721733.

Gibbs, J. P., and S. M. Melvin. 1993. Call-response surveys for monitoring breeding waterbirds. Journal of Wildlife Management 57:27-34.

Gibbs, J. P., S. Woodward, M. L. Hunter, and A. E. Hutchinson. 1987. Determinants of great blue heron colony distribution in coastal Maine. Auk 104:38-47.

Gilmer, D. S, R. E. Kirby, I. J. Ball, and J. H. Riechmann. 1977. Post-breeding activities of 
mallards and wood ducks in north-central Minnesota. Journal of Wildlife Management 41:345-359.

Graves, B. M., and S. H. Anderson. 1987. Habitat suitability index models: snapping turtle. U. S. Fish and Wildlife Service Biological Report 82(10.141).

Green, N. B., and T. K. Pauley. 1987. Amphibians and reptiles in West Virginia. University of Pittsburgh Press, Pittsburgh, Pennsylvania.

Hamas, M. J. 1974. Human incursion and nesting sites of the belted kingfisher. Auk 91:835836.

Haramis, G. M. 1990. Breeding ecology of the wood duck: a review. Pages 45-60 in L. H. Fredrickson, G. V. Burger, S. P. Havera, D. A. Graber, R. E. Kirby, and T. S. Taylor, editors. Proceedings of the 1988 North American Wood Duck Symposium, St. Louis, Missouri.

Havera, S. P., L. R. Boens, M. M. Georgi, and R. T. Shealy. 1992. Human disturbance of waterfowl on Keokuk Pool, Mississippi River. Wildlife Society Bulletin 20:290-298.

Hecnar, S. J., and R. T. M'Closkey. 1997. The effects of predatory fish on amphibian species richness and distribution. Biological Conservation 79:123-131.

Hepp, G. R., and J. D. Hair. 1977. Wood duck brood mobility and utilization of beaver pond habitats. Proceedings of the Annual Conference of the Southeastern Association of Fish and Wildlife Agencies 31:216-225.

Hesse, L. W. 1996. Floral and faunal trends in the middle Missouri River. Pages 73-90 in Galat, D. L., and Frazier, A. G., editors. Overview of river-floodplain ecology in the Upper Mississippi River Basin, v. 3 of Kelmelis, J. A., editor. Science for floodplain management into the $21^{\text {st }}$ century, Washington, D. C. 
Howard, R. J. 1985. A stream habitat classification system for beaver. Journal of Wildlife Management 49:19-25.

Imhof, T. A. 1962. Alabama birds. University of Alabama Press, University, Alabama.

Jenkins, S. H. 1979. Seasonal and year-to-year differences in food selection by beavers. Oecologia. (Berl.) 44:112-116.

Jenkins, S. H. 1981. Problems, progress, and prospects in studies of food selection by beavers. Pages 559-579 in J. A. Chapman and D. Pursley, editors. Worldwide Furbearer Conference Proceedings, Vol. 1, Aug. 3-11, 1980, Frostburg, Maryland.

Johnson, B. L., W. B. Richardson, and T. J. Naimo. 1995. Past, present, and future concepts in large river ecology. BioScience 45:134-141.

Jones, C., R. S. Hoffman, D. W. Rice, M. D. Engstrom, R. D. Bradley, D. J. Schmidly, C. A. Jones and R. J. Baker. 1997. Revised checklist of North American mammals north of Mexico. Occasional Papers of the Museum of Texas Tech University number 173.

Kaiser, M. S., and E. K. Fritzell. 1984. Effects of river recreationists on green-backed heron behavior. Journal of Wildlife Management 48:561-567.

Kats, L. B., J. W. Petranka, and A. Sih. 1988. Antipredator defenses and the persistence of amphibian larvae with fishes. Ecology 69:1865-1870.

Klein, M. L. 1993. Waterbird behavioral responses to human disturbances. Wildlife Society Bulletin 21:31-39.

Kupferberg, S. J. 1996. Hydrologic and geomorphic factors affecting conservation of a riverbreeding frog (Rana boylii). Ecological Applications 6:1332-1344.

Kushlan, J. A. 1978. Feeding ecology of wading birds. Wading birds. National Audubon Society Research Report 7:249-297. 
Licht, L. E. 1968. Unpalatability and toxicity of toad eggs. Herpetologica 24:93-98.

Magurran, A. E. 1988. Ecological diversity and its measurement. Princeton University Press, Princeton, New Jersey.

McGilvrey, F. B. (compiler). 1968. A guide to wood duck production habitat requirements. Bureau of Sport Fish and Wildlife Resources Publication 60.

Melquist, W. E., J. S. Whitman, and M. G. Hornocker. 1981. Resource partitioning and coexistence of sympatric mink and river otter populations. Pages 187-220 in J. A. Chapman and D. Pursley, editors. Worldwide Furbearer Conference Proceedings, Vol. 1, Aug. 3-11, 1980, Frostburg, Maryland.

Millard, M. J. 1993. Nearshore habitat use by larval fishes near two islands in the upper Ohio River. Dissertation, West Virginia University, Morgantown, West Virginia.

Minser, W. G. 1993. The relationship of wood duck brood density to river habitat factors. Proceedings of the Annual Conference of the Southeastern Fish and Wildlife Agencies 47:112-122.

Moll, D. 1980. Dirty river turtles. Natural History 5:42-49.

Mossman, M. 1994. Wisconsin frog and toad survey instructions. Endangered Species Branch, Wisconsin DNR, Madison, Wisconsin.

National Climatic Data Center. 2003. Online. World Wide Web. http://wf.ncdc.noaa.gov/oa/climate/cag3/NA.html

National Weather Service. 2003. Climate database. Charleston, West Virginia.

Patuxent Wildlife Research Center. 2003. Online. World Wide Web. http://www.mp2pwrc.usgs.gov/naamp/

Petranka, J. W., L. B. Kats, and A. Sih. 1987. Predator-prey interactions among fish and larval 
amphibians: use of chemical cues to detect predatory fish. Animal Behaviour 35:420425.

Prose, B. L. 1985. Habitat suitability index models: Belted kingfisher. U. S. Fish and Wildlife Service Biological Report 82(10.87).

Reid, G. K. 1961. Ecology of inland waters and estuaries. D. Van Nostrand Co., New York, New York.

Resetarits, W. J., Jr., and H. M. Wilbur. 1989. Oviposition site choice in Hyla chrysoscelis: role of predators and competitors. Ecology 70:220-228.

Resetarits, W. J., Jr., and H. M. Wilbur. 1991. Calling site choice by Hyla chrysoscelis: effect of predators, competitors, and oviposition sites. Ecology 72:778-786.

Sacilotto, K. A. 2002. An assessment of natural cavity abundance, nest box use, and management recommendations for birds on the Ohio River Islands National Wildlife Refuge, West Virginia. Thesis, West Virginia University, Morgantown, West Virginia.

SAS Institute. 1990. SAS/STAT ${ }^{\circledR}$ user's guide. Version 6. Fourth edition. Volume 2. SAS institute, Cary, North Carolina.

Semlitsch, R. D. 2000. Principles for management of aquatic-breeding amphibians. Journal of Wildlife Management 64:615-631.

Semlitsch, R. D. 2002. Critical elements for biologically based recovery plans of aquaticbreeding amphibians. Conservation Biology 16:619-629.

Shannon, C. E., and W. Weaver. 1949. The mathematical theory of communication. University of Illinois Press, Urbanna, Illinois.

Short, H. L., and R. J. Cooper. 1985. Habitat suitability index models: Great blue heron. U. S. Fish and Wildlife Service Biological Report 82(10.99), Washington, D. C. 
Smith, R. L., and L. D. Flake. 1985. Movements and habitats of brood-rearing wood ducks on a prairie river. Journal of Wildlife Management 49:437-442.

Steidl, R. J., and R. G. Anthony. 1996. Responses of bald eagles to human activity during the summer in interior Alaska. Ecological Applications 6:482-491.

Stratman, D. 2000. Using micro and macrotopography in wetland restoration. Indiana Biology technical note 1. U. S. Department of Agriculture, Natural Resources Conservation Service, Indianapolis, Indiana.

Thompson, D. 1973. Feeding ecology of diving ducks on Keokuk Pool, Mississippi River. Journal of Wildlife Management 37:367-381.

Thompson, D. H. 1979. Feeding areas of great blue herons and great egrets nesting within the floodplain of the upper Mississippi River. Proceedings of the 1978 Conference of the Colonial Waterbird Group 2:202-213.

Tolin, W. A., and P. A. Schettig. 1983. A physical and biological survey of the Ohio River islands (Huntington District). U. S. Fish and Wildlife Service, Elkins, West Virginia.

Thorp, J. H. 1992. Linkage between islands and benthos in the Ohio River, with implications for riverine management. Canadian Journal of Fisheries and Aquatic Sciences 49:18721882.

U. S. Army Corps of Engineers. 1981. Final environmental statement on Ohio River, PA to KY (mile 0 to mile 438) commercial sand and gravel dredging operations. U. S. Army Engineer District, Pittsburgh, Pennsylvania.

U. S. Army Corps of Engineers. 2000. Ohio River ecosystem restoration program, integrated decision document and environmental assessment. U. S. Army Corps of Engineers, Great Lakes and Ohio River Division, Cincinnati, Ohio. 
U. S. Fish and Wildlife Service. 1989. Final environmental assessment, Ohio River Islands National Wildlife Refuge, proposal. U. S. Fish and Wildlife Service, Region 5, Newton Corner, Massachusetts.

U. S. Fish and Wildlife Service. 2000. Draft comprehensive conservation plan and environmental assessment, Ohio River Islands National Wildlife Refuge. U. S. Fish and Wildlife Service, Hadley, Massachusetts.

U. S. Fish and Wildlife Service. 2002. Ohio River Islands National Wildlife Refuge, comprehensive conservation plan. U. S. Fish and Wildlife Service, Parkersburg, West Virginia.

U. S. Geological Survey. 2002. A gap analysis of West Virginia: final report and data. Natural Resources Analysis Center, West Virginia University, Morgantown, West Virginia.

Vandewalle, T. J., and J. L. Christiansen. 1996. A relationship between river modification and species richness of freshwater turtles in Iowa. Journal of the Iowa Academy of Science 103:1-8.

Voris, H. K., and J. P. Bacon. 1966. Differential predation on tadpoles. Copeia 1966:594-598.

Watts, B. D., and D. S. Bradshaw. 1994. The influence of human disturbance on the location of great blue heron colonies in the lower Chesapeake Bay. Colonial Waterbirds 17:184186.

Webster, C. G., and F. B. McGilvrey. 1966. Providing brood habitat for wood ducks. Pages 7075 in J. B. Trefethen, editor. Wood duck management and research: a symposium. Wildlife Management Institute, Washington, D. C.

Weller, M. W. 1999. Wetland birds, habitat resources and conservation implications. Cambridge University Press, New York, New York. 
White, H. C. 1953. The eastern belted kingfisher in the Maritime Provinces. Fisheries Resources Board of Canada Bulletin 97.

Zeto, M. A., W. A. Tolin, and J. E. Schmidt. 1987. The freshwater mussels, Unionidae, of the upper Ohio River, Greenup and Belleville Pools, West Virginia, USA. Nautilus 101:182185. 
CHAPTER II. TABLES 
Table 1. Frequency (no. birds/km), species richness (no. species/channel) and diversity (Shannon \& Weaver 1949) of all waterbirds, and frequency of waterfowl, wading birds, and 5 waterbird species encountered on back and main channels, averaged by channel across years, associated with 10 islands on the Ohio River, West Virginia, USA, 2001-2002.

\begin{tabular}{|c|c|c|c|c|c|c|c|c|}
\hline \multirow[b]{3}{*}{ Variable } & \multirow[b]{3}{*}{ Season $^{\mathrm{b}}$} & \multirow[b]{3}{*}{ Measure } & \multicolumn{4}{|c|}{ Channel $^{\mathrm{a}}$} & \multirow[b]{3}{*}{$F_{1,27}{ }^{\mathrm{c}}$} & \multirow[b]{3}{*}{$P$} \\
\hline & & & \multicolumn{2}{|c|}{ Back } & \multicolumn{2}{|c|}{ Main } & & \\
\hline & & & $\bar{x}$ & $\mathrm{SE}$ & $\bar{x}$ & $\mathrm{SE}$ & & \\
\hline \multirow[t]{3}{*}{ All waterbirds ${ }^{\mathrm{d}}$} & Total & Frequency & 6.66 & 0.74 & 5.37 & 0.78 & 4.26 & 0.049 \\
\hline & Total & Richness & 2.41 & 0.14 & 2.16 & 0.13 & 1.91 & 0.178 \\
\hline & Total & Diversity & 0.62 & 0.04 & 0.57 & 0.04 & 0.77 & 0.387 \\
\hline Waterfowl ${ }^{\mathrm{e}}$ & Total & Frequency & 5.52 & 0.71 & 3.90 & 0.73 & 11.94 & 0.002 \\
\hline Wading birds ${ }^{f}$ & Total & Frequency & 0.74 & 0.10 & 0.66 & 0.12 & 1.09 & 0.306 \\
\hline \multirow[t]{5}{*}{ Belted kingfisher } & Spring & Frequency & 0.13 & 0.05 & 0.24 & 0.11 & 0.17 & 0.686 \\
\hline & Summer & Frequency & 0.35 & 0.08 & 0.95 & 0.19 & 13.79 & 0.001 \\
\hline & Fall & Frequency & 0.43 & 0.11 & 0.60 & 0.10 & 2.48 & 0.127 \\
\hline & Winter & Frequency & 0.21 & 0.09 & 0.30 & 0.13 & 0.48 & 0.495 \\
\hline & Total & Frequency & 0.29 & 0.04 & 0.56 & 0.07 & & \\
\hline \multirow[t]{5}{*}{ Canada goose } & Spring & Frequency & 2.82 & 0.60 & 2.89 & 0.49 & 0.81 & 0.377 \\
\hline & Summer & Frequency & 3.77 & 1.52 & 5.58 & 2.04 & 1.38 & 0.250 \\
\hline & Fall & Frequency & 0.13 & 0.10 & 0.31 & 0.20 & 0.25 & 0.624 \\
\hline & Winter & Frequency & 4.83 & 1.94 & 2.05 & 1.38 & 2.51 & 0.125 \\
\hline & Total & Frequency & 2.61 & 0.56 & 2.80 & 0.65 & & \\
\hline Great blue heron & Total & Frequency & 0.58 & 0.10 & 0.34 & 0.04 & 1.09 & 0.305 \\
\hline \multirow[t]{5}{*}{ Mallard } & Spring & Frequency & 0.98 & 0.31 & 0.25 & 0.08 & 5.56 & 0.026 \\
\hline & Summer & Frequency & 0.85 & 0.36 & 0.41 & 0.11 & 0.15 & 0.699 \\
\hline & Fall & Frequency & 0.34 & 0.20 & 0.07 & 0.04 & 0.79 & 0.382 \\
\hline & Winter & Frequency & 0.59 & 0.21 & 0.07 & 0.07 & 11.03 & 0.003 \\
\hline & Total & Frequency & 0.70 & 0.15 & 0.22 & 0.04 & & \\
\hline Wood duck & Total & Frequency & 1.73 & 0.25 & 0.55 & 0.24 & 29.89 & $<0.001$ \\
\hline
\end{tabular}

${ }^{a}$ Back channel: back channel-island and back channel-mainland side treatments; main channel: main channel-island and main channel-mainland side treatments. Each treatment encompassed the length of the associated island and one-half of the width of the associated back channel.

${ }^{b}$ Spring: 21 March-7 April 2001, 23-25 March 2002; summer: 14-28 May, 11-27 June 2002, 1625 May, 17-26 June, 17 July-13 August 2002; fall: 10-16 November 2001, 28 September-6 October 2002; winter: 26-28 January 2002.

${ }^{c}$ No test indicates test was not performed, due to interaction with season $(\mathrm{P} \leq 0.05)$.

${ }^{d}$ Waterfowl and associates, wading birds, seabirds, and belted kingfishers

${ }^{e}$ Ducks and geese

${ }^{f}$ Herons, sandpipers, and killdeer 
Table 2. Frequency (no. birds/km), species richness (no. species/treatment) and diversity (Shannon \& Weaver 1949) of all waterbirds, and frequency of waterfowl, wading birds and 5 waterbird species encountered in 4 treatments $(\mathrm{BI}=$ back channel-island side, $\mathrm{BM}=$ back channel-mainland side, $\mathrm{MI}=$ main channel-island side, $\mathrm{MM}=$ main channel-mainland side), averaged by treatment across years, associated with 10 islands on the Ohio River, West Virginia, USA, 2001-2002.

\begin{tabular}{|c|c|c|c|c|c|c|c|c|c|c|c|c|}
\hline \multirow[b]{3}{*}{ Variable } & \multirow[b]{3}{*}{ Season $^{\mathrm{b}}$} & \multirow[b]{3}{*}{ Measure } & \multicolumn{8}{|c|}{ Treatment $^{\mathrm{a}}$} & \multirow[b]{3}{*}{$F_{3,27}$} & \multirow[b]{3}{*}{$P$} \\
\hline & & & \multicolumn{2}{|c|}{$\mathrm{BI}$} & \multicolumn{2}{|c|}{$\mathrm{BM}$} & \multicolumn{2}{|c|}{ MI } & \multicolumn{2}{|c|}{$\mathrm{MM}$} & & \\
\hline & & & $x^{\mathrm{c}}$ & SE & $\bar{x}$ & $\mathrm{SE}$ & $\bar{x}$ & $\mathrm{SE}$ & $\bar{x}$ & SE & & \\
\hline \multirow[t]{7}{*}{ All waterbirds ${ }^{\mathrm{d}}$} & Total & Frequency & $7.12 \mathrm{~A}$ & 1.00 & $6.20 \mathrm{~A}$ & 1.09 & $4.74 \mathrm{~A}$ & 0.90 & $6.00 \mathrm{~A}$ & 1.27 & 1.59 & 0.215 \\
\hline & Spring & Richness & $3.80 \mathrm{~A}$ & 0.52 & $2.40 \mathrm{~B}$ & 0.33 & $2.60 \mathrm{~B}$ & 0.44 & $2.45 \mathrm{~B}$ & 0.39 & 3.59 & 0.026 \\
\hline & Summer & Richness & $3.80 \mathrm{~A}$ & 0.52 & $2.40 \mathrm{~A}$ & 0.33 & $2.60 \mathrm{~A}$ & 0.44 & $2.45 \mathrm{~A}$ & 0.39 & 0.98 & 0.417 \\
\hline & Fall & Richness & $3.80 \mathrm{~A}$ & 0.52 & $2.40 \mathrm{~A}$ & 0.33 & $2.60 \mathrm{~A}$ & 0.44 & $2.45 \mathrm{~A}$ & 0.39 & 1.46 & 0.249 \\
\hline & Winter & Richness & $2.00 \mathrm{~A}$ & 0.33 & $2.00 \mathrm{~A}$ & 0.39 & $1.30 \mathrm{~A}$ & 0.47 & $1.60 \mathrm{~A}$ & 0.45 & 0.90 & 0.454 \\
\hline & Total & Richness & 3.80 & 0.52 & 2.40 & 0.33 & 2.60 & 0.44 & 2.45 & 0.39 & & \\
\hline & Total & Diversity & $0.69 \mathrm{~A}$ & 0.06 & $0.55 \mathrm{~A}$ & 0.05 & $0.59 \mathrm{~A}$ & 0.07 & $0.55 \mathrm{~A}$ & 0.06 & 1.07 & 0.379 \\
\hline Waterfowl $^{\mathrm{e}}$ & Total & Frequency & $5.77 \mathrm{~A}$ & 0.94 & $5.28 \mathrm{~A}$ & 1.07 & $3.52 \mathrm{~B}$ & 0.85 & $4.30 \mathrm{~B}$ & 1.19 & 4.07 & 0.016 \\
\hline \multirow[t]{5}{*}{ Wading birds ${ }^{\mathrm{f}}$} & Spring & Frequency & $0.83 \mathrm{~A}$ & 0.34 & $0.29 \mathrm{~B}$ & 0.22 & $0.31 \mathrm{AB}$ & 0.12 & $0.11 \mathrm{~B}$ & 0.05 & 3.22 & 0.038 \\
\hline & Summer & Frequency & $0.95 \mathrm{~A}$ & 0.36 & $1.02 \mathrm{~A}$ & 0.23 & $0.75 \mathrm{~A}$ & 0.13 & $1.00 \mathrm{~A}$ & 0.28 & 0.41 & 0.750 \\
\hline & Fall & Frequency & $0.90 \mathrm{~A}$ & 0.14 & $0.26 \mathrm{C}$ & 0.11 & $0.98 \mathrm{AB}$ & 0.23 & $1.21 \mathrm{BC}$ & 0.70 & 5.66 & 0.004 \\
\hline & Winter & Frequency & $1.70 \mathrm{~A}$ & 0.71 & $0.22 \mathrm{~B}$ & 0.11 & $0.20 \mathrm{~B}$ & 0.11 & $0.36 \mathrm{AB}$ & 0.12 & 3.50 & 0.029 \\
\hline & Total & Frequency & 1.01 & 0.18 & 0.48 & 0.10 & 0.61 & 0.09 & 0.72 & 0.22 & & \\
\hline Belted kingfisher & Total & Frequency & $0.27 \mathrm{~A}$ & 0.06 & $0.31 \mathrm{~A}$ & 0.07 & $0.40 \mathrm{~A}$ & 0.07 & $0.71 \mathrm{~B}$ & 0.13 & 5.27 & 0.005 \\
\hline Canada goose & Total & Frequency & $2.07 \mathrm{~A}$ & 0.55 & $3.16 \mathrm{~A}$ & 0.96 & $2.56 \mathrm{~A}$ & 0.72 & $3.04 \mathrm{~A}$ & 1.09 & 1.18 & 0.336 \\
\hline Great blue heron & Total & Frequency & $0.91 \mathrm{~A}$ & 0.17 & $0.26 \mathrm{~B}$ & 0.07 & $0.43 \mathrm{~B}$ & 0.07 & $0.26 \mathrm{~B}$ & 0.06 & 5.06 & 0.007 \\
\hline \multirow[t]{5}{*}{ Mallard } & Spring & Frequency & $1.43 \mathrm{~A}$ & 0.56 & $0.52 \mathrm{AB}$ & 0.24 & $0.22 \mathrm{~B}$ & 0.12 & $0.28 \mathrm{AB}$ & 0.10 & 3.58 & 0.027 \\
\hline & Summer & Frequency & $0.52 \mathrm{~A}$ & 0.20 & $1.18 \mathrm{~A}$ & 0.68 & $0.31 \mathrm{~A}$ & 0.10 & $0.51 \mathrm{~A}$ & 0.20 & 0.11 & 0.960 \\
\hline & Fall & Frequency & $0.31 \mathrm{~A}$ & 0.23 & $0.37 \mathrm{~A}$ & 0.32 & $0.00 \mathrm{~A}$ & 0.00 & $0.14 \mathrm{~A}$ & 0.08 & 1.14 & 0.352 \\
\hline & Winter & Frequency & $0.43 \mathrm{AB}$ & 0.24 & $0.76 \mathrm{~A}$ & 0.36 & $0.14 \mathrm{~B}$ & 0.14 & $0.00 \mathrm{~B}$ & 0.00 & 4.54 & 0.011 \\
\hline & Total & Frequency & 0.71 & 0.19 & 0.70 & 0.23 & 0.17 & 0.05 & 0.26 & 0.07 & & \\
\hline
\end{tabular}


Table 2. Continued.

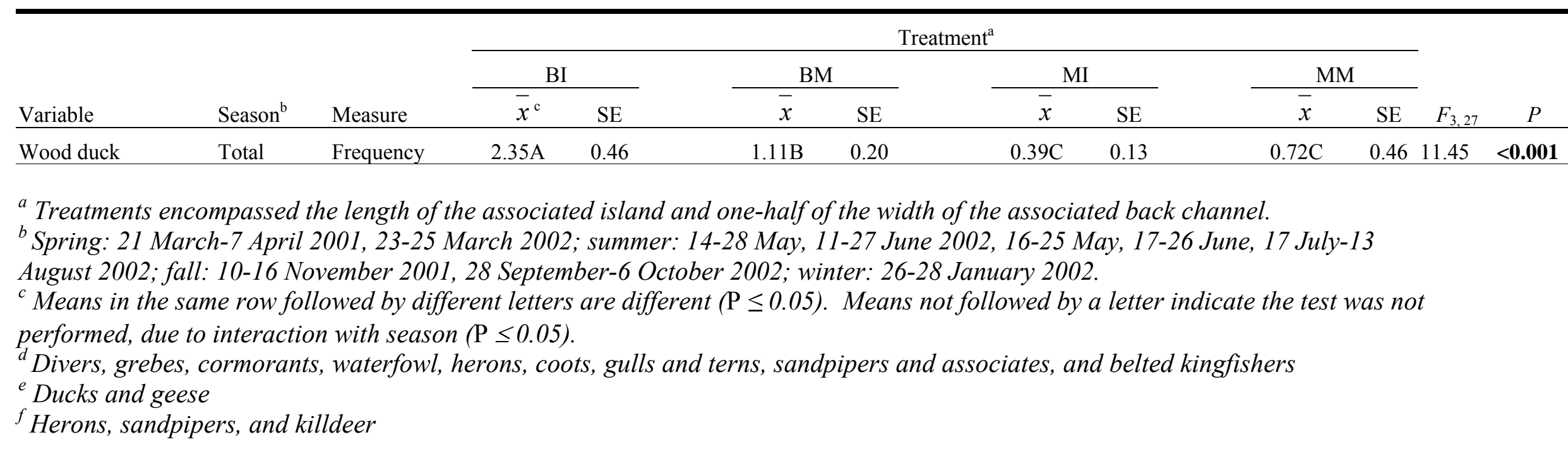


Table 3. Relative abundance of anurans encountered on back and main channels, averaged by channel across years, associated with 10 islands on the Ohio River, West Virginia, USA, 20012002.

\begin{tabular}{|c|c|c|c|c|c|c|}
\hline \multirow[b]{3}{*}{ Period $^{\mathrm{b}}$} & \multicolumn{4}{|c|}{ Channel $^{\mathrm{a}}$} & \multirow[b]{3}{*}{$t^{\mathrm{d}}$} & \multirow[b]{3}{*}{$P$} \\
\hline & \multicolumn{2}{|c|}{ Back } & \multicolumn{2}{|c|}{ Main } & & \\
\hline & $\bar{x}^{\mathrm{c}}$ & $\mathrm{SE}$ & $\bar{x}$ & $\mathrm{SE}$ & & \\
\hline 1 & 0.54 & 0.06 & 0.17 & 0.05 & 5.02 & $<0.001$ \\
\hline 2 & 0.28 & 0.07 & 0.14 & 0.05 & 1.89 & 0.063 \\
\hline 3 & 0.11 & 0.05 & 0.11 & 0.04 & 0.23 & 0.822 \\
\hline Total & 0.31 & 0.04 & 0.14 & 0.03 & & \\
\hline
\end{tabular}

${ }^{a}$ Back channel: back channel-island side and back channel-mainland side treatments; main channel: main channel-island side and main channel-mainland side treatments. Each treatment encompassed the length of the associated island and one-half of the width of the associated back channel.

${ }^{b}$ Period 1: 30 March-11 April 2001, 24 March-15 April 2002; Period 2: 1-17 May 2001, 16-25 May 2002; Period 3: 9-21 July 2001, 22-27 June 2002.

${ }^{c}$ Frequency of 250-m radius plots along channel shorelines at which anurans were heard calling.

${ }^{d}$ No test indicates test was not performed, due to interaction with period $(\mathrm{P} \leq 0.05)$. 
Table 4. Distribution (\%) of call index values (CIV; Mossman 1994) for 3 anuran species encountered on back and main channels, averaged by channel across years, associated with 10 islands on the Ohio River, West Virginia, USA, 2001-2002.

\begin{tabular}{|c|c|c|c|c|c|c|}
\hline \multirow[b]{2}{*}{$\mathrm{CIV}^{\mathrm{a}}$} & \multicolumn{2}{|c|}{$\begin{array}{c}\text { Spring peeper } \\
\text { Channel }^{\mathrm{b}}\end{array}$} & \multicolumn{2}{|c|}{$\begin{array}{c}\text { American toad } \\
\text { Channel }\end{array}$} & \multicolumn{2}{|c|}{$\begin{array}{c}\text { Cope's gray treefrog } \\
\text { Channel }\end{array}$} \\
\hline & Back & Main & Back & Main & Back & Main \\
\hline 0 & 87.27 & 95.37 & 96.53 & 98.38 & 96.30 & 97.45 \\
\hline 1 & 1.85 & 2.31 & 1.62 & 0.46 & 0.92 & 1.85 \\
\hline 2 & 2.31 & 0.23 & 0.69 & 0.93 & 2.31 & 0.69 \\
\hline 3 & 8.56 & 2.08 & 1.16 & 0.23 & 0.46 & 0.00 \\
\hline$X^{2}{ }_{1}$ & \multicolumn{2}{|c|}{17.48} & \multicolumn{2}{|c|}{3.66} & \multicolumn{2}{|c|}{1.01} \\
\hline$P$ & \multicolumn{2}{|c|}{$<0.001$} & \multicolumn{2}{|c|}{0.056} & \multicolumn{2}{|c|}{0.316} \\
\hline
\end{tabular}

${ }^{a} 0:$ No individuals heard calling; 1: Individuals heard calling, no overlap; 2: Some overlapping calls, individuals can be distinguished; 3: Full chorus, individuals cannot be distinguished. ${ }^{b}$ Back channel: back channel-island side and back channel-mainland side treatments; main channel: main channel-island side and main channel-mainland side treatments. Each treatment encompassed the length of the associated island and one-half of the width of the associated back channel. 
Table 5. Relative abundance (no. captured/trap-night) of all turtles, snapping turtles and spiny softshells encountered on back and main channels associated with 10 islands on the Ohio River, West Virginia, USA, 2001-2002.

\begin{tabular}{|c|c|c|c|c|c|c|c|}
\hline \multirow[b]{3}{*}{ Variable } & \multirow[b]{3}{*}{ Season $^{b}$} & \multicolumn{4}{|c|}{ Channel $^{\mathrm{a}}$} & \multirow[b]{3}{*}{$F_{1,27}{ }^{\mathrm{c}}$} & \multirow[b]{3}{*}{$P$} \\
\hline & & \multicolumn{2}{|c|}{ Back } & \multicolumn{2}{|c|}{ Main } & & \\
\hline & & $\bar{x}$ & SE & $\bar{x}$ & $\mathrm{SE}$ & & \\
\hline \multirow[t]{3}{*}{ All turtles ${ }^{\mathrm{d}}$} & Summer & 0.22 & 0.05 & 0.28 & 0.06 & 0.77 & 0.387 \\
\hline & Fall & 0.25 & 0.05 & 0.06 & 0.02 & 9.88 & 0.004 \\
\hline & Total & 0.24 & 0.04 & 0.19 & 0.03 & & \\
\hline Snapping turtle & Total & 0.17 & 0.03 & 0.03 & 0.01 & 28.43 & $<0.001$ \\
\hline \multirow[t]{3}{*}{ Spiny softshell } & Summer & 0.01 & 0.01 & 0.24 & 0.05 & 19.40 & $<0.001$ \\
\hline & Fall & 0.08 & 0.04 & 0.04 & 0.02 & 0.02 & 0.890 \\
\hline & Total & 0.04 & 0.02 & 0.16 & 0.03 & & \\
\hline
\end{tabular}

${ }^{a}$ Back channel: back channel-island side and back channel-mainland side treatments; main channel: main channel-island side and main channel-mainland side treatments. Each treatment encompassed the length of the associated island and one-half of the width of the associated back channel.

${ }^{b}$ Summer: 11-23 June, 12 July-13 August, 26 July-14 August 2002; fall: 23 September-14 October 2001, 5-14 October 2002.

${ }^{c}$ No test indicates test was not performed, due to interaction with season $(\mathrm{P} \leq 0.05)$.

${ }^{d}$ All turtles include painted turtles, smooth softshells, snapping turtles, spiny softshells, and stinkpots. 
Table 6. Relative abundance (no. captured/trap-night) of all turtles, snapping turtles and spiny softshells encountered in 4 treatments ( $\mathrm{BI}=$ back channel-island side, $\mathrm{BM}=$ back channel-mainland side, $\mathrm{MI}=$ main channel-island side, $\mathrm{MM}=$ main channel-mainland side), associated with 10 islands on the Ohio River, West Virginia, USA, 2001-2002.

\begin{tabular}{|c|c|c|c|c|c|c|c|c|c|c|c|}
\hline \multirow[b]{3}{*}{ Variable } & \multirow[b]{3}{*}{ Season $^{b}$} & \multicolumn{8}{|c|}{ Treatment $^{\mathrm{a}}$} & \multirow[b]{3}{*}{$F_{3,27}$} & \multirow[b]{3}{*}{$P$} \\
\hline & & \multicolumn{2}{|c|}{$\mathrm{BI}$} & \multicolumn{2}{|c|}{$\mathrm{BM}$} & \multicolumn{2}{|c|}{ MI } & \multicolumn{2}{|c|}{$\mathrm{MM}$} & & \\
\hline & & $\bar{x}^{\mathrm{c}}$ & SE & $\bar{x}$ & SE & $\bar{x}$ & SE & $\bar{x}$ & SE & & \\
\hline \multirow[t]{3}{*}{ All turtles ${ }^{\mathrm{d}}$} & Summer & $0.30 \mathrm{~A}$ & 0.08 & $0.15 \mathrm{~A}$ & 0.05 & $0.21 \mathrm{~A}$ & 0.06 & $0.36 \mathrm{~A}$ & 0.09 & 1.94 & 0.147 \\
\hline & Fall & $0.28 \mathrm{~A}$ & 0.09 & $0.22 \mathrm{AB}$ & 0.07 & $0.08 \mathrm{BC}$ & 0.04 & $0.05 \mathrm{C}$ & 0.03 & 3.44 & 0.031 \\
\hline & Total & 0.29 & 0.07 & 0.18 & 0.05 & 0.16 & 0.04 & 0.23 & 0.05 & & \\
\hline Snapping turtle & Pooled & $0.19 \mathrm{~A}$ & 0.05 & $0.15 \mathrm{~A}$ & 0.05 & $0.02 \mathrm{~B}$ & 0.01 & $0.03 \mathrm{~B}$ & 0.02 & 9.97 & $<0.001$ \\
\hline \multirow[t]{3}{*}{ Spiny softshell } & Summer & $0.02 \mathrm{~A}$ & 0.02 & $0.00 \mathrm{~A}$ & 0.00 & $0.19 \mathrm{~B}$ & 0.07 & $0.29 \mathrm{~B}$ & 0.08 & 6.90 & 0.001 \\
\hline & Fall & $0.13 \mathrm{~A}$ & 0.08 & $0.03 \mathrm{~A}$ & 0.03 & $0.05 \mathrm{~A}$ & 0.03 & $0.03 \mathrm{~A}$ & 0.03 & 0.34 & 0.799 \\
\hline & Pooled & 0.06 & 0.03 & 0.01 & 0.01 & 0.14 & 0.04 & 0.18 & 0.05 & & \\
\hline
\end{tabular}

\footnotetext{
${ }^{a}$ Treatments encompassed the length of the associated island and 0.5 the width of the associated back channel.

${ }^{b}$ Summer: 11-23 June, 12 July-13 August, 26 July-14 August 2002; fall: 23 September-14 October 2001, 5-14 October 2002.

${ }^{c}$ Means in the same row followed by different letters are different $(\mathrm{P} \leq 0.05)$. Means not followed by a letter indicate the test was not performed, due to interaction with season $(\mathrm{P} \leq 0.05)$.

${ }^{d}$ All turtles include painted turtles, smooth softshells, snapping turtles, spiny softshells, and stinkpots.
} 
Table 7. Percent (\%) land cover types on back channel-mainland side (BM) and main channel-mainland side (MM) treatment shorelines, within $300 \mathrm{~m}$ of the water's edge, associated with 10 islands on the Ohio River, West Virginia, USA (U. S. Geological Survey 2002).

\begin{tabular}{|c|c|c|c|c|c|c|}
\hline \multirow[b]{3}{*}{ Land cover type } & \multicolumn{4}{|c|}{ Treatment shoreline } & \multirow[b]{3}{*}{$F_{1,9}$} & \multirow[b]{3}{*}{$P$} \\
\hline & \multicolumn{2}{|c|}{$\mathrm{BM}$} & \multicolumn{2}{|c|}{$\mathrm{MM}$} & & \\
\hline & $\bar{x}$ & SE & $\bar{x}$ & SE & & \\
\hline Barren land-mining/construction & 0.73 & 0.25 & 4.54 & 1.82 & 5.64 & 0.042 \\
\hline Forest & 41.39 & 8.92 & 28.05 & 7.86 & 1.04 & 0.335 \\
\hline Pasture/grassland & 23.01 & 6.12 & 34.82 & 6.95 & 1.29 & 0.285 \\
\hline Row crops/agriculture & 7.38 & 1.90 & 7.01 & 2.87 & 0.27 & 0.616 \\
\hline Urban/developed & 24.73 & 7.36 & 18.45 & 5.28 & 0.58 & 0.468 \\
\hline Wetland & 2.77 & 0.96 & 7.12 & 1.75 & 8.53 & 0.017 \\
\hline
\end{tabular}


CHAPTER II. FIGURES 


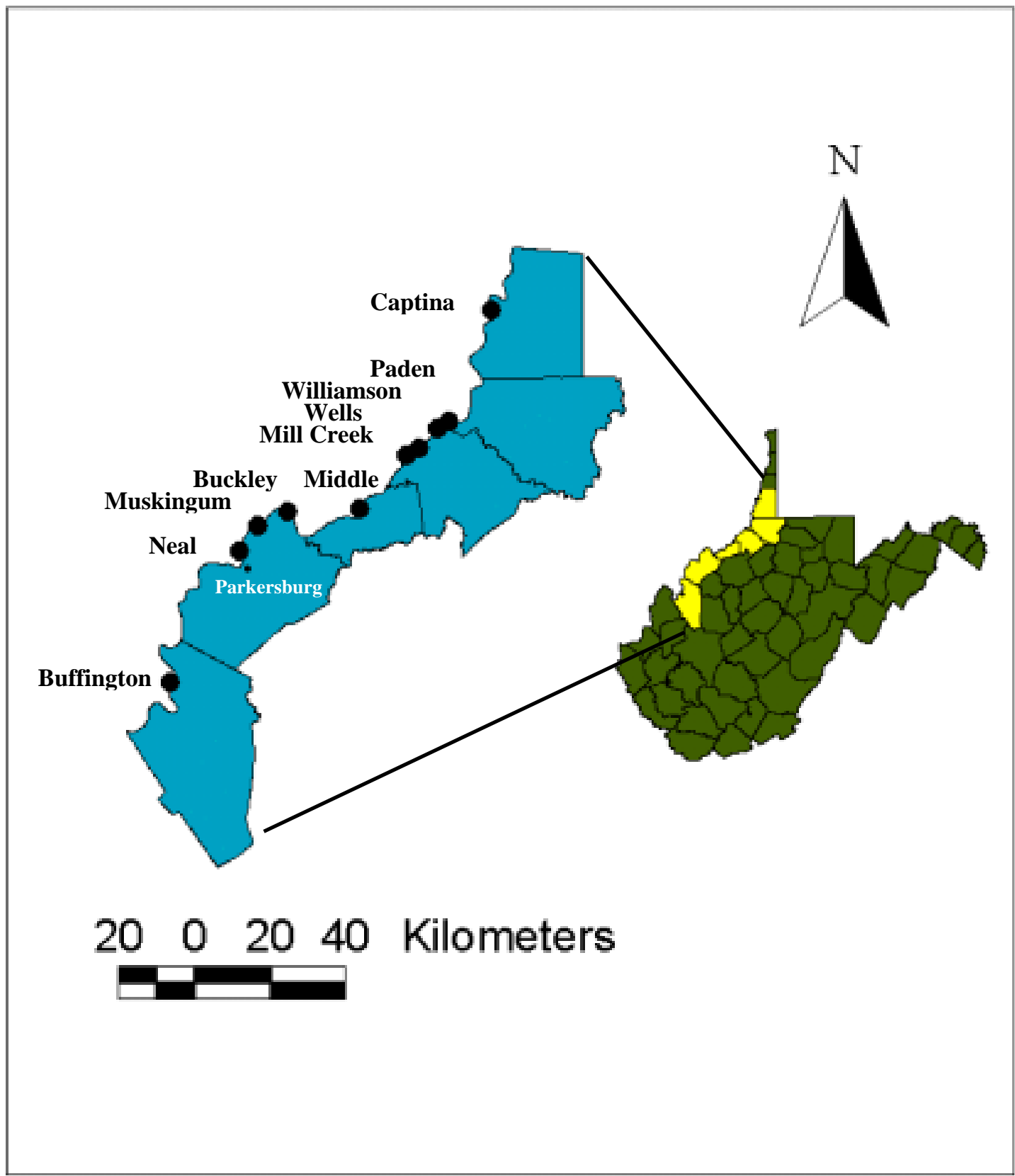

Figure 1. Location of 10 islands (names in black type), between river kilometer 174 and 349, on the Ohio River, West Virginia, USA. 


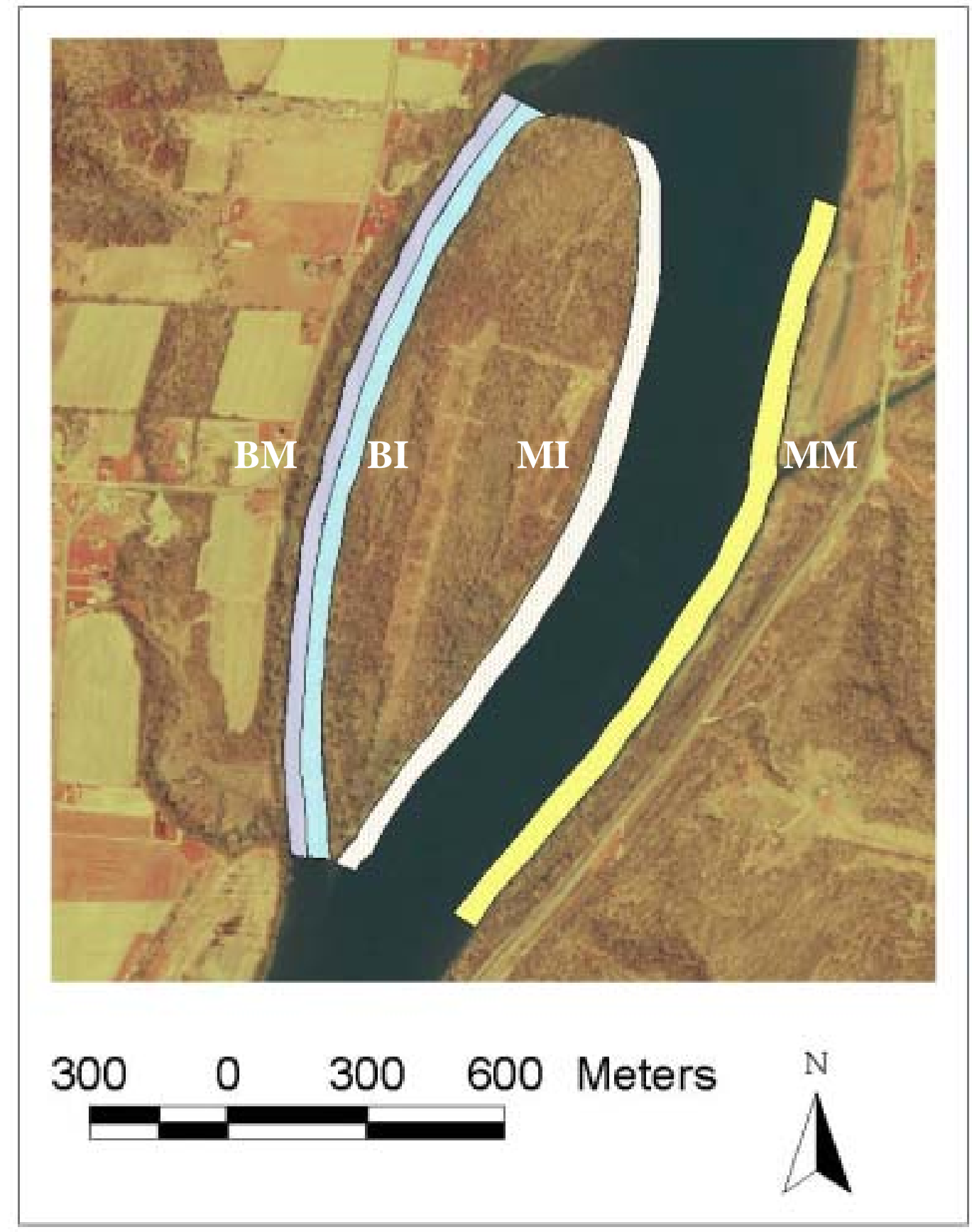

Figure 2. An island (Buffington) on the Ohio River, West Virginia, USA (the state of Ohio is on the left [west] bank), illustrating 4 treatments (BM: back channel-mainland side; BI: back channel-island side; MI: main channel-island side; MM: main channel-mainland side). Each treatment encompasses the length of the associated island and one-half of the width of the associated back channel. 


\title{
CHAPTER III
}

\section{HABITAT QUALITY FOR SELECTED SPECIES ON BACK CHANNELS} ASSOCIATED WITH ISLANDS ON THE OHIO RIVER, WEST VIRGINIA, USA

\author{
ANDREW K. ZADNIK \\ azadnik@hotmail.com \\ West Virginia University \\ Division of Forestry \\ P. O. Box 6125 \\ Morgantown, WV 26506-6125
}


Abstract: The islands and associated back channels on the Ohio River are generally believed to provide features considered critical for the habitat requirements of several wildlife species. However, few studies have quantitatively evaluated habitat quality in these areas. The objective of this study was to evaluate habitat quality of back channel and main channel areas for belted kingfishers (Ceryle alcyon), great blue herons (Ardea herodias), American mink (hereafter mink; Mustela vison), common muskrat (hereafter muskrat; Ondatra zibethicus), snapping turtles (Chelydra serpentina), and wood ducks (Aix sponsa) using habitat suitability index (HSI) models. To test the effectiveness of these models for use on the Ohio River, I related, when possible, HSI scores and the variables measured for each model with measures of relative abundance for the model species. The belted kingfisher HSI was greater on the main $(\bar{x}=0.42$, $\mathrm{SE}=0.01)$ than back $(\bar{x}=0.34, \mathrm{SE}=0.01)$ channel $(P<0.001)$. However, the model failed to predict kingfisher abundance. The reproduction component of the great blue heron HSI was greater on the back $(\bar{x}=0.58, \mathrm{SE}=0.10)$ than main $(\bar{x}=0.39, \mathrm{SE}=0.10)$ channel $(P=0.027)$. The total heron model was positively related to the number of herons observed $/ \mathrm{km}$ of shoreline. Although their relative abundance was not estimated, the mink HSI model had a higher score on the island $(\bar{x}=0.86, \mathrm{SE}=0.02)$ than mainland $(\bar{x}=0.77, \mathrm{SE}=0.02)$ side $(P=0.001)$. The muskrat HSI was greater on the back $(\bar{x}=0.58, \mathrm{SE}=0.01)$ than main $(\bar{x}=0.54, \mathrm{SE}=0.01)$ channel $(P=0.004)$. The muskrat model was positively related with relative abundance. The winter cover component of the snapping turtle HSI was greater on the back $(\bar{x}=0.34, \mathrm{SE}=$ $0.01)$ than main $(\bar{x}=0.30, \mathrm{SE}=0.02)$ channel $(P=0.016)$. The winter cover component was

This chapter is in the style of the Wildlife Society Bulletin 
positively related with turtle abundance. Finally, the brood-rearing component of the wood duck HSI model was greater on the back $(\bar{x}=0.08, \mathrm{SE}=0.01)$ than main $(\bar{x}=0.02, \mathrm{SE}=0.00)$ channel $(P<0.001)$. The brood-rearing component was positively related with wood duck abundance. The back channels provide characteristics not found elsewhere on the Ohio River and should be conserved as important riparian wildlife habitat.

Wildlife Society Bulletin 00(0):000-000

$\underline{\text { Key words: Ohio River, island back channel, riparian wildlife, habitat suitability, West Virginia. }}$

\section{INTRODUCTION}

The Ohio River has been dramatically altered over the past 200 years primarily due to industrialization and navigational projects (Tolin and Schettig 1983). Many of the islands on the river have been completely eliminated or severely degraded due to these activities (Tolin and Schettig 1983, U. S. Army Corps of Engineers 2000). Current activities viewed as threats to the river, islands, and surrounding areas include commercial sand and gravel dredging, industrial development, gas/oil wells, logging, mooring activities, and to an extent, recreational activities and residential development (Tolin and Schettig 1983, U. S. Fish and Wildlife Service 1989).

The islands and associated back channels (areas not receiving commercial barge traffic) on the Ohio River are generally believed to provide features considered critical for the habitat requirements of several wildlife species (Tolin and Schettig 1983). However, few studies have quantitatively evaluated the quality of these areas for wildlife (Thorp 1992, Millard 1993, Sacilotto 2002). This information is important to assist West Virginia Division of Natural Resources (WVDNR) personnel in determining what, if any, types of activities are compatible with conserving these areas as critical riparian wildlife habitat. 
A widely accepted method to assess the habitat quality of an area for particular species is the use of HSI models (Brooks 1997, Morrison et al. 1998). These models were originally developed by the U. S. Fish and Wildlife Service (USFWS) as part of the Habitat Evaluation Procedures (USFWS 1980, 1981). The models are based on measurements of structural variables necessary for important life requisites of individual species. Each variable is scored from $0-1$, and then entered into a formula to calculate a final HSI score, also 0-1. The higher the final HSI score, the higher the habitat quality may be considered for that species (USFWS 1981). The relationship between HSI scores and carrying capacity is assumed to be positively linear (USFWS 1981).

The need to evaluate HSI model performance is commonly recognized (Thomasma et al. 1991, Bender et al. 1996, Brooks 1997, Roloff and Kernohan 1999). The preferable means to accomplish this is by testing a model against population measures, such as species density or reproductive success (Brooks 1997, Prosser and Brooks 1998). Results of studies attempting such a correlation have been inconsistent (Clark and Lewis 1983, Cook and Irwin 1985, Thomasma et al. 1991, Robel et al. 1993; see Chapter 1). Thus, considering the demand for a rapid assessment method, further validation studies have been encouraged (Brooks 1997, Roloff and Kernohan 1999).

In 2002, 158 HSI models were available from the USFWS in published form. For this study, I chose models for the belted kingfisher (total model; Prose 1985), great blue heron (total model; Short and Cooper 1985), mink (total model; Allen 1984), muskrat (freshwater model; Allen and Hoffman 1984), snapping turtle (total model; Graves and Anderson 1987), and wood duck (brood-rearing component and winter model; Sousa and Farmer 1983). Summaries of each of these models can be found in Chapter 1. These species are commonly associated with riparian 
areas and are known to exist along the Ohio River (Tolin and Schettig 1983, USFWS 2002).

They also are representative of different taxonomic groups. Furthermore, I believed the variables measured in accordance with these models should provide a thorough representation of the overall quality of habitat characteristics in the study area.

My main objective with this study was to evaluate the potential wildlife value, based on habitat characteristics, of back channel and main channel areas associated with islands on the Ohio River, through the use of several HSI models. In addition, to test the effectiveness of these models for Ohio River wildlife, I attempted to relate, when possible, HSI scores and the variables measured for each model with measures of relative abundance for the model species.

\section{STUDY AREA}

I conducted this study on back channel and main channel areas associated with 10 islands (Captina, Paden, Williamson, Wells, Mill Creek, Middle, Buckley, Muskingum, Neal, and Buffington) on the Ohio River, West Virginia. These islands were chosen because they have true back channels; areas off to one side of the river that do not receive commercial barge traffic (P. Morrison, USFWS personal communication). They all are part of the Ohio River Islands National Wildlife Refuge (ORINWR; USFWS 2000). They occurred between river kilometer 174 and 349 in 4 separate navigational pools (USFWS 1989). A thorough description of the study area can be found in Chapter 1.

The climate of the study area is moderate. The average yearly temperature for West Virginia, from $1895-2002$, was $11.05{ }^{\circ} \mathrm{C}($ range $=9.44-12.61$; National Climatic Data Center 2003). The average annual precipitation was $111.84 \mathrm{~cm}($ range $=65.38-153.16)$. Daily temperatures during 2001-2002 at Huntington, West Virginia, USA ( 154 km southwest from 
the midpoint of the study area) ranged from $0.06-25.17^{\circ} \mathrm{C}(\bar{x}=13.61, \mathrm{SE}=1.72)$. Monthly precipitation ranged from 2.79-22.56 cm $(\bar{x}=8.90, \mathrm{SE}=1.14$; National Weather Service 2003).

\section{METHODS}

\section{Study Design}

For this study, I divided the area around each island into 4 channel-side treatments: the back channel near the mainland side (back channel-mainland [BM]), the back channel near the island side (BI), the main channel near the island side (MI), and the main channel near the mainland side $(\mathrm{MM})$. Thus, there were 2 treatments for each channel (back $=\mathrm{BM}$ and $\mathrm{BI}$, main $=\mathrm{MM}$ and $\mathrm{MI}$ ) and 2 treatments for each side (island $=\mathrm{BI}$ and $\mathrm{MI}$, and mainland $=\mathrm{BM}$ and MM). Each treatment encompassed the entire length of the associated island. To maintain consistency across islands, I selected the width of each treatment as half the width of the associated back channel $(\bar{x}=54.27 \mathrm{~m}, \mathrm{SE}=9.74)$.

\section{Habitat Variables}

I evaluated each treatment once during this study using the published HSI models for the belted kingfisher, great blue heron, mink, muskrat, snapping turtle, and wood duck. A total of 27 variables were measured and used in determining HSI scores (Table 1). One variable, percent of year with surface water present, was used for 2 different models (mink and muskrat). Many variables were measured using the line intercept method (Hays et al. 1981). This required first establishing transects running perpendicular to the flow of water and extending the width of each treatment. The first transect for each treatment was randomly placed, with the remaining set at 250-m intervals. The number of transects per island ranged from 4 to 19 , although an equal 
number of transects was established per treatment across each island. The coverage of interest that projected onto each transect was recorded, divided by the total transect length and multiplied by 100 to obtain a percent estimate. All field measurements were taken from a boat MaySeptember 2001 and 2002. Each measured variable was given a suitability index (SI) determined by the specific model. The indices were then used to determine indices for specific life requisites (e.g., cover, reproduction, and food components) and/or final HSI scores.

Belted Kingfisher Model.--I could not evaluate Captina or Mill Creek Islands using the belted kingfisher model because the treatments did not meet the minimum shoreline length $(\geq 1$ $\mathrm{km}$; Prose 1985). Most variables for this model were considered $\leq 15 \mathrm{~m}$ from shore. The model assumed that foraging activity for this species primarily occurs within this zone (Hamas, personal communication, as cited by Prose 1985).

I measured water transparency $\leq 15 \mathrm{~m}$ from shore by randomly taking 1 reading along each transect using a Secchi disk (Orth 1983), and percent surface obstruction by determining the coverage $\leq 15 \mathrm{~m}$ from shore of overhanging woody vegetation, woody downfall, leaves, and herbaceous vegetation that projected onto each transect (Hays et al. 1981; Table 1). I measured the percent of the water area $\leq 15 \mathrm{~m}$ from shore that was $\leq 60 \mathrm{~cm}$ deep along each transect using a graduated rod and the percent of riffles in each treatment by using a measuring tape.

The relationship between perches and cover for the belted kingfisher model is based on the number of $25-\mathrm{m}$ channel subsections $/ \mathrm{km}$ that contain $\geq 1$ potential perch (Prose 1985). For each treatment, I randomly located a 1-km section and divided it into $4025-\mathrm{m}$ subsections. I then evaluated each subsection to determine if it contained $\geq 1$ potential perch. I determined the shortest distance from a subsection containing $\geq 1$ potential perch to a potential nesting bank (Prose 1985) by using on-site inspections along with aerial photos and topographic maps 
projected with Geographic Information System software (ArcView, hereafter GIS; ESRI 1994). Potential nesting banks were steep, vertical banks devoid of vegetation, roots, and rocks $\geq 1.3 \mathrm{~m}$ in height and composed of $70-96 \%$ sand and $\leq 15 \%$ clay (Prose 1985). I measured the soil texture of a potential nesting bank using the feel method (Hays et al. 1981).

Great Blue Heron Model.--I measured the distance between potential great blue heron nesting and potential foraging areas by using on-site inspections and GIS (Short and Cooper 1985; Table 1). Whether or not a treatment contained potential foraging areas was based on the number of transects along each treatment that I believed met the necessary criteria to be considered foraging areas (i.e., presence of a shallow water body with suitable prey population and foraging substrate; Short and Cooper 1985). If the majority of transects met the criteria, then the treatment was considered a potential foraging area. I assumed the river contained a suitable prey population (Van Hassel et al. 1988, Millard 1993). I used on-site inspections and GIS to determine the following additional variables: presence of a disturbance-free zone $\geq 100 \mathrm{~m}$ around potential foraging areas, the presence of a potential nesting area (e.g., forest cover type with trees capable for supporting nests; Short and Cooper 1985) $\leq 250 \mathrm{~m}$ from open water, the presence of a $\geq 250$-m (land) or $\geq 150$-m (water) disturbance-free zone around potential nest sites, and the proximity between potential nest sites and active nest sites (Short and Cooper 1985). Potential sources of disturbance included houses, other buildings, and improved roads.

Mink Model.--I determined the percent of the year with surface water present by using local data and on-site inspections (Allen 1984; Table 1). This variable also was used for the muskrat model. I measured the percent woody canopy closure $\leq 100 \mathrm{~m}$ from the water's edge by using GIS and the line intercept method (Hays et al. 1981, Allen 1984). I first transposed the 
transects used for other field measurements onto aerial photos using GIS and extended them 100 m onto land. I then estimated the percent woody canopy that was overlaid by these transects.

Muskrat Model.--I measured the percent stream gradient in each treatment with GIS and the ArcView map measurer tool by dividing the change in elevation between 2 points along the riverine reach by the horizontal distance between those 2 points and multiplying by 100 (Allen and Hoffman 1984; Table 1). I measured the percent of channel with surface water present, percent emergent vegetation, and the percent herbaceous canopy cover $\leq 10 \mathrm{~m}$ from the water's edge, using the line intercept method (Hays et al. 1981, Allen and Hoffman 1984).

Snapping Turtle Model.--I measured the average water temperature $\left({ }^{\circ} \mathrm{C}\right)$ at mid-depth during the summer with a temperature sensitive probe (Graves and Anderson 1987; Table 1). One transect was randomly chosen per treatment and temperature readings taken every $5 \mathrm{~m}$. Current velocity was determined by measuring the time it took for a neutrally buoyant object (an orange) to travel $5 \mathrm{~m}$ down the center of each treatment (Hays et al. 1981, Graves and Anderson 1987). I measured the percent canopy cover of aquatic vegetation in the littoral zone using the line intercept method. Whether the maximum water depth was greater than the maximum ice depth was determined while working on the river during the winter and using local data (Graves and Anderson 1987). I measured the percent silt in the substrate with an Ekman dredge. Five substrate samples were randomly taken from each treatment. When the dredge failed to operate properly, a posthole digger was used. Each sample was air-dried outdoors and in the laboratory for $\sim 2$ months, then oven-dried for $>2$ days, weighed, and passed through a 63 -micron sieve using a sieve shaker. The material that passed through was weighed and divided by the total sample mass (Graves and Anderson 1987). I measured the distance from a treatment to a small stream using GIS and on-site inspections. What is meant by a small stream was not defined in 
the model (Graves and Anderson 1987), but for the purpose of this study, I considered all tributaries of the Ohio River to be small streams. It was not necessary to measure the distance to permanent water, as all of my treatments included the permanent water of the river.

Wood Duck Model.--Captina Island and Mill Creek Island could not be evaluated using the wood duck brood-rearing component because the treatments associated with those islands did not meet the minimum area required for broods ( $\geq 4$ ha; Sousa and Farmer 1983). I could evaluate those islands for the winter component, however, since the model did not specify a minimum area for winter use by this species.

Brood cover was defined in the model to include overhanging woody vegetation $\leq 1 \mathrm{~m}$ from the water's surface, woody downfall, leaves, and herbaceous (persistent and nonpersistent) vegetation (Sousa and Farmer 1983). Winter cover was considered the same, except that any herbaceous vegetation had to be winter persistent. I measured the percent of each cover component using the line intercept method (Hays et al. 1981; Table 1).

\section{Wildlife population measures}

Waterbirds.--Counts of all conspicuous belted kingfishers, great blue herons and wood ducks in each treatment were made from a boat traveling just above idle speed parallel to and $\approx 10 \mathrm{~m}$ from shore. Individuals were identified to age-class and sex if possible, and their distance from shore estimated to the nearest $10-\mathrm{m}$. Those observed on shore but $\leq 10 \mathrm{~m}$ from the water's edge were counted as occurring in the associated treatment. The relative abundance of the 3 species was calculated as the density (no./ha of treatment area) and frequency (no./ $/ \mathrm{km}$ of treatment shoreline) of each observed during the surveys. Frequency was measured because of the linear nature of the river and the fact that most waterbirds observed were $\leq 5 \mathrm{~m}$ from shore 
(unpublished data). Density was measured due to the present state of the river as a series of connected lakes rather than a free-flowing system (Frost and Mitsch 1989).

In 2001, waterbird surveys were conducted once in the spring (21 March-7 April), twice in the summer (14-28 May, 11-27 June), and once in the fall (10-16 November). In 2002, surveys were conducted once in the winter (26-28 January), once in the spring (23-25 March), 3 times in the summer (16-25 May, 17-26 June, 17 July-13 August), and once in the fall (28 September-6 October). To avoid double counting observations from the multiple summer periods, the period with the maximum number of individuals of each species observed per year was used in the analyses. The fall, winter, and spring surveys took place at any time during daylight hours all days of the week. Summer surveys were conducted between 30 minutes before and 4 hours after sunrise (Gibbs and Melvin 1993). Summer surveys were usually not conducted on Saturday or Sunday due to increased interference from recreational boating activity on those days. Nighttime waterbird surveys were not conducted due to safety concerns. Common and scientific names of birds follow American Ornithologists' Union (1998).

Snapping Turtles.--Turtle trapping was conducted once in fall 2001 (23 September-14 October), three times in summer 2002 (11-23 June, 12-24 July [9 islands], 13 August [1 island], 25 July-14 August), and once in fall 2002 (5-14 October). Turtles were captured using commercially available nylon hoop nets $(1.5-\mathrm{m}$ long $\times 0.9$-m diameter $)$ with 5 -cm mesh (Memphis Net and Twine Company, Inc., Memphis, Tennessee, USA). Traps were baited each day with chopped fish (canned or frozen) contained in nylon mesh bags and suspended from the center hoop of each trap. Two traps were set along each treatment in areas considered suitable for turtles, such as sand or gravel bars, areas of emergent vegetation, or areas of woody debris (Ernst et al. 1994). Locations were changed each trapping period to maximize the potential to 
encounter new turtles. Traps were set for 1 night before being moved. A trap-night was considered as 1 trap found completely intact the day after being set. A trap found with a hole torn in it $\leq 18 \mathrm{~cm}$ in diameter was counted as 0.5 trap-night, because the potential to capture large turtles ( $>8$-cm carapace width) remained. Missing traps, those found to be collapsed, or those with holes $>8 \mathrm{~cm}$ were counted as 0 trap-nights. Snapping turtle relative abundance was calculated as the number captured/trap-night.

All captured snapping turtles were weighed, measured, sexed and aged if possible (see Ernst et al. 1994), shell-notched (Cagle 1939), and released at the capture site. Calipers were used to measure carapace length and width to the nearest 0.1 centimeter. A Pesola spring scale was used to obtain mass of individuals $\leq 5 \mathrm{~kg}$. A scale capable of weighing individuals $>5 \mathrm{~kg}$ was occasionally available in 2002. Common and scientific names of turtles follow Crother (2000).

Muskrats.--Muskrat relative abundance was based on direct observations or the observation of appropriate sign (i.e., tracks, scat, cuttings, middens, burrows, lodges, food caches, etc.). Appropriate sign was searched for within a 15-m zone to each side of each transect. Each treatment was examined once for appropriate sign during the course of this study. Direct observations were counted as they occurred. Relative abundance was calculated as the frequency of transects on which each species was detected during this study. Due to logistic constraints, no measure of mink relative abundance was estimated. Common and scientific names of mammals follow Jones et al. (1997). 


\section{Statistical Analyses}

I used 2 complete block design analyses of variance (ANOVA) with SAS (SAS Institute 1990) to test final HSI scores and scores for particular model components (dependent variables), in which the effects of the islands were blocked. One ANOVA used treatment as the independent variable. The second ANOVA evaluated channel and side as independent variables. I used 2 separate ANOVAs because determining channel differences was the primary interest of the WVDNR. Island was used as a blocking factor to remove the effects of the inherent differences between individual islands. Fisher's Least Significance Difference (LSD) test was used for mean separation of treatments. I transformed data as needed to meet normality and homogenous variance assumptions. Final HSI and model component data were log transformed. I used an alpha level of 0.05 for all statistical analyses. Presented means and standard errors are untransformed to ease interpretation.

I also evaluated the relative abundance of belted kingfishes, great blue herons, wood ducks, snapping turtles, and muskrat (dependent variables) using 2 complete block design ANOVAs, in which the effects of the islands were blocked. One ANOVA used treatment, year, season, and their interactions as independent variables. The second evaluated channel, side, year, season, and their interactions as independent variables. Fisher's LSD test was used for mean separation of treatments. Belted kingfisher, great blue heron, snapping turtle, and wood duck relative abundance data were log transformed. Muskrat relative abundance data were power transformed.

I used simple linear regression to relate final HSI and (when applicable) life requisite scores by treatment with measures of relative abundance by treatment. In this analysis, all data were $\log$ transformed. I used multiple regression using the backward variable selection 
procedure to relate the individual habitat variables for each model by treatment with measures of relative abundance by treatment. Muskrat data were power transformed for this analysis. I log transformed data for the other models.

I tested all HSI models, components, and variables against species relative abundance data from the season(s) stated or implied by the model. I tested the wood duck brood-rearing suitability index and variable only with summer relative abundance. I used fall and winter relative abundance with the winter HSI score and variable (Sousa and Farmer 1983). The belted kingfisher and great blue heron HSI models were designed to evaluate an area for breeding; thus, I tested scores and variables for those models against spring and summer relative abundance (Prose 1985, Short and Cooper 1985). The snapping turtle model was designed to evaluate an area to provide year-round habitat, so I tested HSI scores and variables for that model against total turtle relative abundance (Graves and Anderson 1987). The muskrat model also is intended to evaluate year-round habitat in an area (Allan and Hoffman 1984). In measuring muskrat relative abundance, I took into account activity (i.e., sign) that may have occurred at different times of the year. Therefore, it was appropriate for me to apply the HSI model and variables to that measure. No attempt was made to validate the mink HSI model.

\section{RESULTS}

\section{Belted kingfisher}

The belted kingfisher total HSI model and water component had higher mean scores on the main channel than back channel (Table 2), and higher scores on the MI and MM treatments than BI and BM treatments (Table 3). Measurements for all variables, component scores, and HSI scores are presented in Appendix N. Belted kingfisher relative abundance was higher on the 
main channel than the back channel during the summer (Table 4). Total (spring and summer) abundance was similar between treatments (Table 5). Belted kingfisher density and frequency showed no channel, side, or treatment interactions with year $(F \leq 2.80, P \geq 0.058$; Appendix $\mathrm{O})$. There also were no side or treatment interactions with season $(F \leq 2.25, P \geq 0.092)$. There were channel $\times$ season interactions $\left(F_{1,60} \geq 4.96, P \leq 0.030\right)$; thus, further analyses were conducted within spring and summer for channel effects.

The model and all components failed to show a linear relationship with density or frequency (Table 6). However, multiple regression analyses indicated that water transparency (Variable 2) and percent riffles (Variable 5) were positively related with belted kingfisher density and frequency, and formed the best-fit model, based on the Akaike Information Criterion (AIC) value (Table 7).

\section{Great blue heron}

The great blue heron reproduction component of the HSI model had a higher mean score on the back channel than the main channel (Table 2), and a higher score on the BI, BM, and MI treatments than the MM treatment (Table 3). The total HSI model and foraging component had higher scores on the BI and MI than BM and MM treatments. Great blue heron abundance was similar between channels (Table 4) and treatments (Table 5). However, mean frequency was greater on the island side than mainland side. There were no channel, side, or treatment interactions with year $(F \leq 3.68, P \geq 0.063)$ or season ( $F \leq 1.34, P \geq 0.251$; Appendix $\mathrm{O})$.

A linear association was found between the total HSI model and frequency (Table 6). However, I found no relation between the model variables and great blue heron density or frequency (Table 7). The best-fit model to predict density, based on AIC value, included 
proximity of potential and active nest sites (Variable 6). The best-fit model to predict frequency included presence of a disturbance-free zone around potential nesting areas (Variable 5) and proximity of potential and active nest sites (Variable 6).

\section{Mink}

The mink total HSI model had a higher mean score on the island side than mainland side (Table 2). Furthermore, the mean HSI score was higher on the BI than BM or MM treatments (Table 3). The score on the MI treatment also was higher than the MM treatment. Validation of the mink HSI model was not attempted because I did not collect abundance data.

\section{Muskrat}

The muskrat total HSI model and food component had higher mean scores on the back channel than main channel (Table 2). In addition, the BI treatment had a higher score than the MI and MM treatments (Table 3). Muskrat relative abundance, based on the frequency of sign and direct observations, was greater on the back channel than main channel (Table 4), and greater on the $\mathrm{BI}$ and $\mathrm{BM}$ treatments than the $\mathrm{MI}$ and $\mathrm{MM}$ treatments (Table 5). Both the total HSI score and the food component had linear associations with relative abundance (Table 6). Results of the multiple regression analysis showed a positive relation between percent herbaceous canopy cover $\leq 10 \mathrm{~m}$ from the water's edge (Variable 6) and relative abundance (Table 7). 


\section{Snapping turtle}

The snapping turtle food component and total HSI model had higher scores on the main channel than back channel (Table 2). Similarly, the total model and food component had higher scores on the MM than BI and BM treatments (Table 3). Conversely, scores for the winter cover component were higher on the back channel than the main channel, and higher on the BI, BM, and MM than MI treatments. The reproduction component of the model had higher scores on the BM and MM than MI treatments. Snapping turtles had a greater mean relative abundance on the back channel than the main channel (Table 4), and a greater abundance on the BI and BM treatments than the MI and MM treatments (Table 5). Snapping turtle relative abundance showed no channel, side, or treatment interactions with the multiple summer periods $(F \leq 2.09, P$ $\geq 0.131$ ) or multiple fall periods ( $F \leq 0.62, P \geq 0.438$; Appendix $\mathrm{O})$. When those periods were combined for each season, there were no channel, side, or treatment interactions with season $(F \leq$ $1.34, P \geq 0.275)$

There was a linear association between the winter cover component and relative abundance (Table 6). Similarly, percent silt (Variable 5), 1 variable that makes up the winter cover component, was found to be positively related with relative abundance (Table 7). Though significant, the correlation between percent silt and relative abundance is rather weak $\left(\mathrm{R}^{2}=0.12\right.$; Table 7), indicating additional variability not accounted for by the model.

\section{Wood duck}

The wood duck brood-rearing component and winter model had higher scores on the back channel than the main channel (Table 2), and higher scores on the BI and BM than MI and MM treatments (Table 3). Wood duck summer relative abundance, which included all adults and 
juveniles (corresponding to the brood-rearing component), and fall abundance (corresponding to the winter model) was greater on the back channel than the main channel (Table 4). Additionally, summer relative abundance was greater on BI and BM than MI and MM treatments (Table 5). Fall relative abundance was greater on BI than MI and MM treatments. There were no wood ducks observed during the winter survey. There were no channel, side, or treatment interactions with year $(F \leq 4.05, P \geq 0.052$; Appendix $\mathrm{O})$.

The wood duck brood-rearing component showed a linear relation with relative abundance (Table 6). Not surprisingly, as the only variable in the model, I found percent brood cover (Variable 4) to be positively related with relative abundance (Table 7).

\section{DISCUSSION}

My study clearly shows that Ohio River island back channels provide better quality habitat, based on HSI scores, than the main channel for species requiring abundant vegetative cover. Specific cover components that are more abundant on back channels include floating and submerged woody debris, overhanging tree limbs, and herbaceous vegetation along the shorelines. Back channels also provide a substrate higher in silt content than the main channel. In addition, the back channels in combination with the islands (i.e., BI treatments) provide protection from human disturbance.

I found the effectiveness of HSI models for predicting population estimates to be mixed. I was able to find relationships that some HSI models, components, and/or variables had with population estimates. However, modifications to several of the models are needed to improve their accuracy for use on the Ohio River and other large rivers. 


\section{Belted Kingfisher}

All variables measured for the belted kingfisher model showed some difference between back and main channels. Water transparency on the main channel was, on average, $>10 \%$ greater than on the back channels, and the main channel had $>11 \%$ more areas of water $<60 \mathrm{~cm}$ deep than the back channels. Surface obstruction was $>5$ times less on the main channel than back channels. Also, although extensive areas of riffles once occurred at the heads of the islands (USFWS 2002), due to gravel dredging and navigational activities, the few areas that I observed were at the mouths of tributaries along the MM treatments. Conversely, the back channels appeared to have a higher $\%$ of potential perches than the main channel, although the average distance from potential perches to potential nesting banks was slightly less on the main channel.

Although I did not find that the belted kingfisher model and components had linear associations with population estimates, 2 of the model variables did, water transparency and percent riffles. Thus, the abundance of this species on the main channel relative to the back channels is at least partially due to increased foraging opportunities. Kingfishers require clear water to locate potential prey (Davis 1980). Also, kingfishers are known to forage in areas of riffles (Davis 1982, Brooks and Davis 1987). To better address the effects of water transparency and riffles on belted kingfisher habitat, and possibly improve the accuracy of the HSI model on the Ohio River, the suitability indices given to these variables should be modified. For instance, the highest indices could be assigned to variables measured in treatments containing the highest abundance of kingfishers. 


\section{Great Blue Heron}

For the great blue heron model, only the presence or absence of disturbance-free areas around foraging and nesting areas appeared to differ between channels. I found that the back channels were $5 \%$ more likely to have disturbance-free areas around potential foraging areas than the main channel. In addition, back channels were $15 \%$ more likely to have disturbancefree areas around potential nesting areas.

Similar to what was reported by Short and Cooper (1985), my results also indicate that areas free from human disturbance are important for great blue herons. On the Ohio River, this condition was met most readily on the islands. Herons are believed to prefer isolation particularly during nesting (Short and Cooper 1985, Gibbs et al. 1987, Watts and Bradshaw 1994). Indeed, all active nests observed within my study area occurred on islands. The back channels may improve nesting conditions provided on the islands both due to the narrowness of most back channels compared to the main channel of the river, as well as slightly greater woody canopy closure along the BM shorelines relative to the MM shorelines (measured for the mink HSI model). These conditions may provide not only disturbance-free zones, compared with the extensive open water and commercial barge traffic on the main channel, but also potentially new nesting sites.

Although I did find a relationship between great blue heron HSI score and frequency, that relationship was rather weak $\left(\mathrm{R}^{2}=0.12\right)$. I believe the model could be improved by modifying the suitability indices given to the variables. Many of the variables are only yes $(\mathrm{SI}=1)$ or no $(\mathrm{SI}=0)$ questions. I suggest that these variables be made continuous, based on the degree to which the area under evaluation meets the necessary criteria. For instance, while a potential nesting area close to primary roads, houses, and shopping centers would still receive a SI of 0 , 
less extreme disturbances, or disturbance that herons could possibly become acclimated to, would receive higher scores. For example, sporadic houses near a nesting area might receive a score of 0.4. If those houses were surrounded by forest, minimizing visibility, the score could be raised to 0.6 . Roads in the vicinity of the nesting area that were unimproved and rarely received traffic could receive a score up to 0.8 . These are just suggestions, additional research is needed to fine-tune the scores, but such changes would likely result in a broader range of HSI scores, which may then relate to varying population estimates.

\section{Mink}

Only $\%$ woody canopy appeared to differ between channels for the mink model. I found that the back channel had $\sim 5 \%$ more canopy closure $\leq 100 \mathrm{~m}$ of the water's edge than main channel, and was greatest on the back channel sides of the islands, or BI treatments.

Although mink abundance was not determined in this study, an increase in mink population has been correlated with an abundance of muskrat, which are commonly preyed upon (Bulmer 1974). Mink also will use abandoned muskrat burrows (Arnold and Fritzell 1989). Muskrat were more abundant on the back channel than main channel. Mink are commonly associated with areas of woody debris, which provide foraging cover and den sites (Melquist et al. 1981). The combination of woody cover and abundant prey likely make the back channel sides of the islands particularly valuable for mink.

\section{Muskrat}

Of the variables measured for the muskrat model, only the amount of herbaceous vegetation along the shorelines appeared to be different between channels. I found that back 
channels had $\sim 15 \%$ more shoreline area covered by herbaceous vegetation than the main channel. The BI treatments had $>20 \%$ more herbaceous coverage than the MM treatments.

According to the HSI model, muskrat cover is primarily provided by persistent emergent vegetation within the river channel (Allen and Hoffman 1984). In my study area, the virtual lack of persistent emergent vegetation meant that cover, as well as food, was provided by shoreline herbaceous vegetation, which was most abundant on the BI treatments. This is shown by the positive relationship the muskrat HSI score, food component, and percent herbaceous cover were found to have with muskrat relative abundance. Additional food and cover was likely provided by woody debris, overhanging tree limbs, and undercut banks (Errington 1937), conditions in more abundance on the back channels. Including measures of these characteristics would likely improve the overall accuracy of the muskrat model.

\section{Snapping Turtle}

Of the variables I measured for the snapping turtle model, current velocity, \% aquatic vegetation, and $\%$ silt in the substrate appeared to differ between channels. I found that current velocity was $2.85 \mathrm{~cm} / \mathrm{sec}$ less on the back channels than main channel. The small amount of aquatic vegetation that I found on the river tended to occur on the main channel. The back channels, however, had $>4 \%$ more silt in the substrate than the main channel.

The obvious discrepancy between snapping turtle total HSI and food component scores compared with relative abundance is primarily due to the weight given aquatic vegetation by the model. The model assumes that a complete absence of aquatic vegetation removes all food value for the area being evaluated (Graves and Anderson 1987). Hence, since the aquatic vegetation observed within my study area occurred primarily on the main channel, that area was considered 
higher quality habitat as compared with back channels. The HSI model states that snapping turtles are primarily carnivorous in early spring, and then switch to a more herbivorous diet later in the spring and summer, feeding on aquatic vegetation (Graves and Anderson 1987). If that was the case in my study area, I should have found a higher abundance of turtles on the main channel than the back channel, particularly in the summer when the few areas of aquatic vegetation appeared (personal observation). While trapping was not conducted in early spring, back channels had a higher abundance of turtles throughout the 2 seasons in which trapping was conducted, summer and fall. Furthermore, main channel turtle abundance stayed consistently low during those seasons. Due to the overall scarcity of aquatic vegetation on the Ohio River, it is probable that snapping turtles remain primarily carnivorous throughout the year, with back channels likely providing more foraging opportunities than the main channel. However, due to the possibility that turtles also may be taking advantage of vegetation that I did not sample, additional trapping and/or research using radiotelemetry is needed to evaluate food selection and identify any seasonal shifts in area use. Nevertheless, the HSI model would be more effective for use on the Ohio River if it put less weight on abundance of aquatic vegetation.

The one variable that was positively related with relative abundance, percent silt in the substrate, reflects the value of back channels as overwintering sites for snapping turtles. Snapping turtles area known to escape from harsh winter conditions by burying themselves deep in the substrate at the bottom of waterbodies (Ernst et al. 1994). The model assumes that substrate with a greater percent of silt is of higher quality for the species (Graves and Anderson 1987). Of course, while silt in the substrate appears to positively affect snapping turtles, suspended silt can have negative impacts on overall habitat quality, particularly for wildlife such as anurans (Bridges and Semlitsch 2002). 
Snapping turtles are typically associated with slower waters (Ernst et al. 1994;

DonnerWright et al. 1999). While it appeared that mean velocity was less on the back channel than main channel, my analyses did not find a correlation between velocity and relative abundance. Even with all model variables included, the correlation with relative abundance remained weak $\left(\mathrm{R}^{2}=0.18\right.$; unpublished data). That still leaves $82 \%$ of the variation in turtle relative abundance unaccounted for by the model. Additional research is needed to identify other factors contributing to turtle abundance.

\section{Wood duck}

Only 1 variable was measured in accordance with the brood-rearing and winter cover components of the wood duck model. This was defined as the amount of woody downfall, emergent vegetation, and overhanging branches $\leq 1 \mathrm{~m}$ from the water's surface (Sousa and Farmer 1983). With the exception of emergent vegetation, which rarely occurred within my study area, I found this variable to be $>3$ times greater on the back channels than the main channel.

The positive relationship I found between brood cover and wood duck relative abundance is similar to other studies. Cottrell et al. (1990) found that wooded shorelines and fallen trees were 2 features that determined use of a river system by Class I ducklings. Minser (1993) found that wood duck brood density $($ no. $/ \mathrm{km})$ in a river was positively related with woody debris in the water and large overhanging trees. In general, woody overhead cover is considered an essential component of good brood habitat (Webster and McGilvrey 1966).

Although emergent vegetation is considered a characteristic of wood duck brood habitat, for it to be considered winter cover as well, it must be persistent (Sousa and Farmer 1983). 
Other studies have noted that nonbreeding habitat is considered similar to high quality brood habitat (Gilmer et al. 1977, McGilvrey 1968, Haramis 1990), a common feature being the presence of woody vegetation (Hein and Haugen 1966). Hence, due to the aforementioned lack of emergent vegetation in my study area, winter cover was considered identical to brood cover. The lack of relation between the winter model and relative abundance is likely due to the absence of wood ducks during the winter survey. This is not surprising, however, as the West Virginia portion of the Ohio River is at the far northern edge of the wood duck's wintering range (Bellrose 1980). Furthermore, although the back channels in particular were used for broodrearing (Chapter 2), the overall lower quality of wood duck habitat on the river compared to other wetland types (Balcombe 2003) may have limited use of the study area by this species.

\section{MANAGEMENT IMPLICATIONS}

With the continuing pressure to develop Ohio River island back channels and back channel mainland shorelines, the need to better understand important habitat characteristics for wildlife in these areas is clear. I found that particular habitat characteristics on the back channels were not as prevalent on the main channel. This led to higher abundances of some wildlife species on the back channel. These characteristics included herbaceous vegetation along the shorelines, abundant woody downfall and overhanging limbs, and a substrate with high silt content. Other back channel characteristics that may potentially benefit wildlife include protection from human disturbance and slower water current. Conversely, characteristics that seemed to benefit species on the main channel included overall less turbid water and riffle areas.

Due to the uniqueness and rarity of back channels on the Ohio River, these areas should be conserved. Furthermore, the characteristics deemed to provide the best quality wildlife 
habitat on the back channels (e.g., submerged and floating woody debris, overhanging branches, and vegetated shorelines) should be enhanced. Herbaceous shoreline vegetation also should be diversified by controlling exotic invasive species, such as Japanese knotweed (Polygonum cuspidatum). On the main channel, riffle areas should be enhanced, preferably by restoring areas of gravel at the heads of the islands. This would benefit species such as belted kingfishers and slow island erosion.

I recommend that the total HSI model for the muskrat and the brood-rearing model for the wood duck, if properly applied, can both be used to successfully predict habitat quality for those species on the Ohio River. In addition, the great blue heron total model can be used with limited success, although modification of the variable suitability indices would likely improve the model's effectiveness. The mink model is likely a good indicator of habitat quality for that species, although further research is needed to relate model scores with relative abundance. The snapping turtle total HSI model should be modified to put less emphasis on aquatic vegetation. The winter cover component of the model can be used to some extent to predict use of the river by snapping turtles. However, further research is needed to identify other variables affecting snapping turtle relative abundance. The belted kingfisher model needs to be modified to better predict use of the river, possibly by changing the suitability indices given to measures of water transparency and riffle area.

\section{LITERATURE CITED}

Allen, A. W. 1984. Habitat suitability index models: mink. U. S. Fish and Wildlife Service. FWS/OBS-82/10.61 Revised. 
Allen, A. W., and R. D. Hoffman. 1984. Habitat suitability index models: muskrat. U. S. Fish and Wildlife Service. FWS/OBS-82/10.46.

American Ornithologists' Union. 1998. Check-list of North American birds, Seventh edition. AOU and Allen Press, Lawrence, Kansas, USA.

Arnold, T. W., and E. K. Fritzell. 1989. Spring summer prey remains collected from male mink dens in southwestern Manitoba. Prairie Naturalist 21:189-192.

Balcombe, C. K. 2003. An evaluation of vegetative communities and wildlife habitat use in mitigated and natural wetlands of West Virginia. Thesis, West Virginia University, Morgantown, West Virginia, USA.

Bellrose, F. C. 1980. Ducks, geese and swans of North America. Stackpole Books, Harrisburg, Pennsylvania, USA.

Bender, L. C., G. J. Roloff, and J. B. Haufler. 1996. Evaluating confidence intervals for habitat suitability models. Wildlife Society Bulletin 24:347-352.

Bridges, C. M., and R. D. Semlitsch. 2002. Linking xenobiotics to amphibian declines. In press in M. Lannoo, editor. Status and conservation of U. S. amphibians. Volume 1. Conservation essays. In press, University of California Press, Berkeley, California, USA.

Brooks, R. P. 1997. Improving habitat suitability index models. Wildlife Society Bulletin 25:163-167.

Brooks, R. P., and W. J. Davis. 1987. Habitat selection by breeding belted kingfishers (Ceryle alcyon). American Midland Naturalist 117:63-70.

Bulmer, M. G. 1974. A statistical analysis of the 10-year cycle in Canada. Journal of Animal Ecology 43:701-718.

Cagle, F. R. 1939. A system of marking turtles for future identification. Copeia 1939:170-173. 
Clark, J. D., and J. C. Lewis. 1983. A validity test of a habitat suitability index model for clapper rail. Proceedings of the Annual Conference of the Southeastern Association of Fish and Wildlife Agencies 37:95-102.

Cook, J. G., and L. L. Irwin. 1985. Validation and modification of a habitat suitability model for pronghorns. Wildlife Society Bulletin 13:440-448.

Cottrell, S. D., H. H. Prince, and P. I. Padding. 1990. Nest success, duckling survival, and brood habitat selection of wood ducks in a Tennessee riverine system. Pages 191-197 in L. H. Fredrickson, G. V. Burger, S. P. Havera, D. A. Graber, R. E. Kirby, and T. S. Taylor, editors. Proceedings of the 1988 North American Wood Duck Symposium, St. Louis, Missouri, USA.

Crother, B. I. 2000 (2001). Scientific and standard English names of amphibians and reptiles of North America north of Mexico, with comments regarding confidence in our understanding. SSAR Herpetological Circular 29.

Davis, W. J. 1980. The belted kingfisher, Megaceryle alcyon: its ecology and territoriality. Thesis, University of Cincinnati, Cincinnati, Ohio, USA.

Davis, W. J. 1982. Territory size in Megaceryle alcyon along a stream habitat. Auk 99:353362.

DonnerWright, D. M., M. A. Bozek, J. R. Probst, and E. M. Anderson. 1999. Response of turtle assemblage to environmental gradients in the St., Croix River in Minnesota and Wisconsin, U.S.A. Canadian journal of zoology 77:989-1000.

Ernst, C. H., R. W. Barbour, and J. E. Lovich. 1994. Turtles of the United States and Canada. Smithsonian Institution Press, Washington, D. C., USA. 
Errington, P. L. 1937. Habitat requirements of stream-dwelling muskrats. Transactions of the North American Wildlife Conference 2:411-416.

ESRI. 1994. ARC/INFO. Version 7.01. Environmental Systems Research Institute. Redlands, California, USA.

Frost, S. L., and W. J. Mitsch. 1989. Resource development and conservation history along the Ohio River. Ohio Journal of Science 89:143-152.

Gibbs, J. P., and S. M. Melvin. 1993. Call-response surveys for monitoring breeding waterbirds. Journal of Wildlife Management 57:27-34.

Gibbs, J. P., S. Woodward, M. L. Hunter, and A. E. Hutchinson. 1987. Determinants of great blue heron colony distribution in coastal Maine. Auk 104:38-47.

Gilmer, D. S, R. E. Kirby, I. J. Ball, and J. H. Riechmann. 1977. Post-breeding activities of mallards and wood ducks in north-central Minnesota. Journal of Wildlife Management 41:345-359.

Graves, B. M., and S. H. Anderson. 1987. Habitat suitability index models: snapping turtle. U. S. Fish and Wildlife Service Biological Report 82(10.141).

Haramis, G. M. 1990. The breeding ecology of the wood duck: a review. Pages 45-60 in L. H. Fredrickson, g. V. Burger, S. P. Havera, D. A. Graber, R. E. Kirby, and T. S. Taylor, editors. Proceedings of the 1988 North American Wood Duck Symposium, St. Louis, Missouri, USA.

Hays, R. L., C. Summers, and W. Seitz. 1981. Estimating wildlife habitat variables. U. S. Fish and Wildlife Service. FWS/OBS-81/47.

Hein, D. A., and A. O. Haugen. 1966. Autumn roosting slight counts as an index to wood duck abundance. Journal of Wildlife Management 30:657-668. 
Jones, C., R. S. Hoffman, D. W. Rice, M. D. Engstrom, R. D. Bradley, D. J. Schmidly, C. A. Jones and R. J. Baker. 1997. Revised checklist of North American mammals north of Mexico. Occasional Papers of the Museum of Texas Tech University number 173.

McGilvrey, F. B. (compiler). 1968. A guide to wood duck production habitat requirements. Bureau of Sport Fish and Wildlife Resources Publication 60.

Melquist, W. E., J. S. Whitman, and M. G. Hornocker. 1981. Resource partitioning and coexistence of sympatric mink and river otter populations. Pages 187-220 in J. A. Chapman and D. Pursley, editors. Worldwide Furbearer Conference Proceedings, Vol. 1, Aug. 3-11, 1980, Frostburg, Maryland, USA.

Millard, M. J. 1993. Nearshore habitat use by larval fishes near two islands in the upper Ohio River. Dissertation, West Virginia University, Morgantown, West Virginia, USA.

Minser, W. G. 1993. The relationship of wood duck brood density to river habitat factors. Proceedings of the Annual Conference of the Southeastern Fish and Wildlife Agencies 47:112-122.

Morrison, M. L., B. G. Marcot, and R. W. Mannan. 1998. Wildlife habitat relationships: concepts and applications. Second Edition. University of Wisconsin Press, Madison, Wisconsin, USA.

National Climatic Data Center. 2002. Online. World Wide Web. http://lwf.ncdc.noaa.gov/oa/ncdc.html National Weather Service. 2003. Climate database. Charleston, West Virginia, USA. Orth, D. J. 1983. Aquatic habitat measurements. Pages 61-84 in L. A. Nielsen and D. L. Johnson, editors. Fisheries techniques. American Fisheries Society, Bethesda, Maryland, USA. 
Prose, B. L. 1985. Habitat suitability index models: belted kingfisher. U. S. Fish and Wildlife Service Biological Report 82(10.87).

Prosser, D. J., and R. B. Brooks. 1998. A verified habitat suitability index for the Louisiana waterthrush. Journal of Field Ornithology 69:288-298.

Robel, R. J., L. B. Fox, and K. E. Kemp. 1993. Relationship between habitat suitability index values and ground counts of beaver colonies in Kansas. Wildlife Society Bulletin 21:415-421.

Roloff, G. J., and B. J. Kernohan. 1999. Evaluating reliability of habitat suitability index models. Wildlife Society Bulletin 27:973-985.

Sacilotto, K. A. 2002. An assessment of natural cavity abundance, nest box use, and management recommendations for birds on the Ohio River Islands National Wildlife Refuge, West Virginia. Thesis, West Virginia University, Morgantown, West Virginia, USA.

SAS Institute. 1990. SAS/STAT ${ }^{\circledR}$ user's guide. Version 6. Fourth edition. Volume 2. SAS institute, Cary, North Carolina, USA.

Short, H. L., and R. J. Cooper. 1985. Habitat suitability index models: great blue heron. U. S. Fish and Wildlife Service Biological Report 82(10.99).

Sousa, P. J., and A. H. Farmer. 1983. Habitat suitability index models: wood duck. U. S. Fish and Wildlife Service. FWS/OBS-82/10.43.

Thomasma, L. E., T. D. Drummer, and R. O. Peterson. 1991. Testing the habitat suitability index model for the fisher. Wildlife Society Bulletin 19:291-297. 
Thorp, J. H. 1992. Linkage between islands and benthos in the Ohio River, with implications for riverine management. Canadian Journal of Fisheries and Aquatic Sciences 49:18721882.

Tolin, W. A., and P. A. Schettig. 1983. A physical and biological survey of the Ohio River islands (Huntington District). U. S. Fish and Wildlife Service, Elkins, West Virginia, USA.

U. S. Army Corps of Engineers. 2000. Ohio River ecosystem restoration program, integrated decision document and environmental assessment. U. S. Army Corps of Engineers, Great Lakes and Ohio River Division, Cincinnati, Ohio, USA.

U. S. Fish and Wildlife Service. 1980. Habitat evaluation procedures (HEP). U. S. Fish and Wildlife Service. ESM 102.

U. S. Fish and Wildlife Service. 1981. Standards for the development of habitat suitability index models. U. S. Fish and Wildlife Service, Release No. 1-81, 103 ESM 103.

U. S. Fish and Wildlife Service. 1989. Final environmental assessment, Ohio River Islands National Wildlife Refuge, proposal. U. S. Fish and Wildlife Service, Region 5, Newton Corner, Massachusetts, USA.

U. S. Fish and Wildlife Service. 2000. Draft comprehensive conservation plan and environmental assessment, Ohio River Islands National Wildlife Refuge. U. S. Fish and Wildlife Service, Hadley, Massachusetts, USA.

U. S. Fish and Wildlife Service. 2002. Ohio River Islands National Wildlife Refuge, comprehensive conservation plan. U. S. Fish and Wildlife Service, Parkersburg, West Virginia, USA. 
Van Hassel, J. H., R. J. Reash, H. W. Brown, J. L. Thomas, and R. C. Mathews, Jr. 1988. Distribution of upper and middle Ohio River USA fishes, 1973-1985 I., associations with water quality and ecological variables. Journal of Freshwater Ecology 4:441-458.

Watts, B. D., and D. S. Bradshaw. 1994. The influence of human disturbance on the location of great blue heron colonies in the lower Chesapeake Bay. Colonial Waterbirds 17:184-186.

Webster, C. G., and F. B. McGilvrey. 1966. Providing brood habitat for wood ducks. Pages 7075 in J. B. Trefethen, editor. Wood duck management and research: a symposium. Wildlife Management Institute, Washington, D. C., USA. 
CHAPTER III. TABLES 
Table 1. Variables (V) measured and equations used to determine life components (based on variable suitability indices [SI]), and habitat suitability index (HSI) scores for belted kingfisher, great blue heron, mink, muskrat, snapping turtle, and wood duck, on the Ohio River, West Virginia, 2001-2002. ${ }^{a}$

Belted kingfisher (Prose 1985)

$\mathrm{V} 2=$ Water transparency $(\mathrm{m}) \leq 15 \mathrm{~m}$ from shore

$\mathrm{V} 3=$ percent surface obstruction $\leq 15 \mathrm{~m}$ from shore

$\mathrm{V} 4=$ percent water area $\leq 60 \mathrm{~cm} \leq 15 \mathrm{~m}$ from shore

$\mathrm{V} 5=$ percent riffles

$\mathrm{V} 6=$ percent 25 -m shoreline subsections with $\geq 1$ potential perch

$\mathrm{V} 7=$ distance from potential perch to potential nesting bank $(\mathrm{m})$

Water component $=(\operatorname{SIV} 2 \times \operatorname{SIV} 4 \times \operatorname{SIV} 5)^{1 / 3} \times \operatorname{SIV} 3$

Cover component $=$ SIV 6

Reproduction component $=$ SIV7

HSI $=$ lowest of the 3 components

Great blue heron (Short and Cooper 1985)

$\mathrm{V} 1=$ Distance between potential nesting and potential foraging areas $(\mathrm{km})$

$\mathrm{V} 2=$ Presence of potential foraging area?

V3 = Disturbance-free zone $\geq 100 \mathrm{~m}$ around potential foraging area?

$\mathrm{V} 4=$ Presence of potential nesting area $\leq 250 \mathrm{~m}$ from water?

V5 $=$ Disturbance-free zone (250-m over land or 150-m over water) around potential nest area?

V6 $=$ Proximity of potential and active nest sites $(\mathrm{km})$

Foraging component $=\mathrm{SIV} 1 \times \operatorname{SIV} 2 \times \operatorname{SIV} 3$

Reproduction component $=(\operatorname{SIV} 1 \times \operatorname{SIV} 4 \times \operatorname{SIV} 5 \times \operatorname{SIV} 6)^{1 / 2}$

HSI $=(\operatorname{SIV} 1 \times \operatorname{SIV} 2 \times \operatorname{SIV} 3 \times \operatorname{SIV} 4 \times \operatorname{SIV} 5 \times \operatorname{SIV} 6)^{1 / 2}$

Mink (Allen 1984)

$\mathrm{V} 2$ = percent of year with surface water present

$\mathrm{V} 4$ = percent woody canopy closure $\leq 100 \mathrm{~m}$ of water's edge

$\mathrm{HSI}=(\mathrm{SIV} 2 \times \mathrm{SIV} 4)^{1 / 3}$ 
Table 1. Continued.

Muskrat (Allen and Hoffman 1984)

$\mathrm{V} 2=$ percent of year with surface water present

$\mathrm{V} 3=$ percent stream gradient

$\mathrm{V} 4=$ percent of channel with surface water

$\mathrm{V} 5=$ percent of channel with persistent emergent vegetation

V6 $=$ percent herbaceous canopy cover $\leq 10 \mathrm{~m}$ from water's edge

Cover component $=\left([\mathrm{SIV} 2 \times \mathrm{SIV} 3 \times \mathrm{SIV} 4]^{1 / 3}+\mathrm{SIV} 5\right) / 2$

Food component $=(\mathrm{SIV} 6+2[\mathrm{SIV} 5]) / 2$

HSI $=$ lowest of the 2 components

Snapping turtle (Graves and Anderson 1987

$\mathrm{V} 1=$ water temperature at mid-depth during summer $\left({ }^{\circ} \mathrm{C}\right)$

$\mathrm{V} 2=$ current velocity $(\mathrm{cm} / \mathrm{sec})$

$\mathrm{V} 3=$ percent canopy cover of aquatic vegetation

$\mathrm{V} 4=$ maximum water depth $>$ maximum ice depth?

$\mathrm{V} 5=$ percent silt in substrate

$\mathrm{V} 6=$ distance to small stream $(\mathrm{km})$

$\mathrm{V} 7=$ distance to permanent water $(\mathrm{km})$

Food component $=(\operatorname{SIV} 1 \times \operatorname{SIV} 2 \times \operatorname{SIV} 3)^{1 / 3}$

Winter cover component $=\mathrm{SIV} 4 \times \mathrm{SIV} 5$

Reproduction component $=$ SIV6

$\mathrm{HSI}=(\text { food component } \times \text { winter cover component } \times \text { reproduction component })^{1 / 3} \times \mathrm{SIV} 7$

Wood duck (Sousa and Farmer 1983)

$\mathrm{V} 4=$ percent water surface with brood cover

$\mathrm{V} 5=$ percent water surface with winter cover

Brood-rearing component $=$ SIV4

Winter habitat component $=$ SIV5

${ }^{a}$ Variables followed by a question mark have Boolean answers (yes, no), but all others are continuous variables. 
Table 2. Habitat suitability index (HSI) model scores, and the scores of model components, for 6 species, on back and main channels, and island and mainland sides, associated with 10 islands on the Ohio River, West Virginia, USA, 2001-2002. ${ }^{a}$

\begin{tabular}{|c|c|c|c|c|c|c|c|c|c|c|c|c|c|c|}
\hline \multirow[b]{3}{*}{ Model } & \multirow[b]{3}{*}{ Component } & \multicolumn{4}{|c|}{ Channel $^{\mathrm{b}}$} & \multirow[b]{3}{*}{$F$} & \multirow[b]{3}{*}{$P$} & \multicolumn{4}{|c|}{ Side } & \multirow[b]{3}{*}{$F$} & \multirow[b]{3}{*}{$\mathrm{df}$} & \multirow[b]{3}{*}{$P$} \\
\hline & & \multicolumn{2}{|c|}{ Back } & \multicolumn{2}{|c|}{ Main } & & & \multicolumn{2}{|c|}{ Island } & \multicolumn{2}{|c|}{ Mainland } & & & \\
\hline & & $\bar{x}$ & $\mathrm{SE}$ & $\bar{x}$ & $\mathrm{SE}$ & & & $\bar{x}$ & SE & $\bar{x}$ & $\mathrm{SE}$ & & & \\
\hline \multirow[t]{4}{*}{ Belted kingfisher } & Water & 0.34 & 0.01 & 0.44 & 0.01 & 113.06 & $1,21<\mathbf{0 . 0 0 1}$ & 0.38 & 0.01 & 0.39 & 0.02 & 1.20 & 1,21 & 0.286 \\
\hline & Cover & 0.52 & 0.03 & 0.47 & 0.02 & 1.56 & $1,21 \quad 0.225$ & 0.48 & 0.03 & 0.50 & 0.02 & 0.41 & 1,21 & 0.531 \\
\hline & Reproduction & 0.93 & 0.02 & 0.95 & 0.02 & 0.52 & $1,21 \quad 0.480$ & 0.94 & 0.02 & 0.94 & 0.02 & 0.01 & 1,21 & 0.916 \\
\hline & Total HSI & 0.34 & 0.01 & 0.42 & 0.01 & 54.80 & $1,21<\mathbf{0 . 0 0 1}$ & 0.37 & 0.01 & 0.39 & 0.01 & 2.16 & 1,21 & 0.156 \\
\hline \multirow[t]{3}{*}{ Great blue heron } & Foraging & 0.60 & 0.11 & 0.55 & 0.11 & 0.23 & $1,27 \quad 0.632$ & 0.95 & 0.05 & 0.20 & 0.09 & 52.83 & 1,27 & $<0.001$ \\
\hline & Reproduction & 0.58 & 0.10 & 0.39 & 0.10 & 5.49 & $1,27 \quad \mathbf{0 . 0 2 7}$ & 0.67 & 0.09 & 0.30 & 0.10 & 19.64 & 1,27 & 0.001 \\
\hline & Total HSI & 0.40 & 0.10 & 0.33 & 0.10 & 0.65 & $1,27 \quad 0.426$ & 0.66 & 0.09 & 0.07 & 0.05 & 51.43 & 1,27 & $<0.001$ \\
\hline Mink & Total HSI & 0.83 & 0.02 & 0.80 & 0.02 & 2.11 & $1,27 \quad 0.158$ & 0.86 & 0.02 & 0.77 & 0.02 & 13.49 & 1,27 & 0.001 \\
\hline \multirow[t]{3}{*}{ Muskrat } & Cover & 0.60 & 0.00 & 0.60 & 0.00 & 0.82 & $1,27 \quad 0.373$ & 0.60 & 0.00 & 0.60 & 0.00 & 0.82 & 1,27 & 0.373 \\
\hline & Food & 0.63 & 0.01 & 0.55 & 0.02 & 21.23 & $1,27<\mathbf{0 . 0 0 1}$ & 0.62 & 0.02 & 0.56 & 0.02 & 10.38 & 1,27 & 0.003 \\
\hline & Total HSI & 0.58 & 0.01 & 0.54 & 0.01 & 9.89 & $1,27 \quad \mathbf{0 . 0 0 4}$ & 0.60 & 0.01 & 0.55 & 0.01 & 3.85 & 1,27 & 0.060 \\
\hline \multirow[t]{4}{*}{ Snapping turtle } & Food & 0.01 & 0.01 & 0.07 & 0.02 & 10.59 & $1,27 \quad \mathbf{0 . 0 0 3}$ & 0.02 & 0.01 & 0.06 & 0.02 & 4.58 & 1,27 & 0.042 \\
\hline & Winter cover & 0.34 & 0.01 & 0.30 & 0.02 & 6.62 & $1,27 \mathbf{0 . 0 1 6}$ & 0.30 & 0.01 & 0.34 & 0.02 & 5.88 & 1,27 & 0.022 \\
\hline & Reproduction & 0.98 & 0.00 & 0.98 & 0.00 & 0.04 & $1,27 \quad 0.849$ & 0.97 & 0.00 & 0.99 & 0.00 & 8.10 & 1,27 & 0.008 \\
\hline & Total HSI & 0.04 & 0.02 & 0.16 & 0.04 & 9.51 & $1,27 \quad \mathbf{0 . 0 0 5}$ & 0.05 & 0.03 & 0.14 & 0.04 & 4.89 & 1,27 & 0.036 \\
\hline \multirow[t]{2}{*}{ Wood duck } & Brood-rearing & 0.08 & 0.01 & 0.02 & 0.00 & 106.79 & $1,21<\mathbf{0 . 0 0 1}$ & 0.05 & 0.01 & 0.04 & 0.01 & 3.82 & 1,21 & 0.064 \\
\hline & Winter habitat & 0.10 & 0.01 & 0.02 & 0.01 & 67.02 & $1,27<\mathbf{0 . 0 0 1}$ & 0.06 & 0.01 & 0.06 & 0.02 & 0.16 & 1,27 & 0.694 \\
\hline
\end{tabular}

${ }^{a}$ Belted kingfisher model and wood duck brood-rearing component could only be applied to 8 islands due to model parameters.

${ }^{\mathrm{b}}$ Channels encompassed an island and mainland shoreline and extended into the river from each shoreline a distance equal to half the width of the associated back channel. Sides encompassed a back channel and main channel shoreline and extended into the river from each shoreline a distance equal to half the width of the associated back channel. 
Table 3. Habitat suitability index (HSI) model scores, and the scores of model components, for 6 species on 4 treatments, associated with 10 islands on the Ohio River, West Virginia, USA, 2001-2002. ${ }^{a}$

\begin{tabular}{|c|c|c|c|c|c|c|c|c|c|c|c|c|}
\hline \multirow[b]{3}{*}{ Model } & \multirow[b]{3}{*}{ Component } & \multicolumn{8}{|c|}{ Treatment $^{\mathrm{b}}$} & \multirow[b]{3}{*}{$F$} & \multirow[b]{3}{*}{ df } & \multirow[b]{3}{*}{$P$} \\
\hline & & \multicolumn{2}{|c|}{$\mathrm{BI}$} & \multicolumn{2}{|c|}{$\mathrm{BM}$} & \multicolumn{2}{|c|}{ MI } & \multicolumn{2}{|c|}{ MM } & & & \\
\hline & & $\bar{x}^{c}$ & SE & $\bar{x}$ & SE & $\bar{x}$ & $\mathrm{SE}$ & $\bar{x}$ & $\mathrm{SE}$ & & & \\
\hline \multirow[t]{4}{*}{ Belted kingfisher } & Water & $0.33 \mathrm{~B}$ & 0.01 & $0.34 \mathrm{~B}$ & 0.01 & $0.43 \mathrm{~A}$ & 0.01 & $0.44 \mathrm{~A}$ & 0.01 & 38.09 & 3,21 & $<0.001$ \\
\hline & Cover & $0.52 \mathrm{~A}$ & 0.04 & $0.51 \mathrm{~A}$ & 0.04 & $0.44 \mathrm{~A}$ & 0.02 & $0.50 \mathrm{~A}$ & 0.03 & 0.93 & 3,21 & 0.442 \\
\hline & Reproduction & $0.94 \mathrm{~A}$ & 0.02 & $0.93 \mathrm{~A}$ & 0.03 & $0.95 \mathrm{~A}$ & 0.03 & $0.96 \mathrm{~A}$ & 0.03 & 0.23 & 3,21 & 0.875 \\
\hline & Total HSI & $0.33 \mathrm{~B}$ & 0.01 & $0.34 \mathrm{~B}$ & 0.01 & $0.41 \mathrm{~A}$ & 0.02 & $0.44 \mathrm{~A}$ & 0.01 & 19.13 & 3,21 & $<0.001$ \\
\hline \multirow[t]{3}{*}{ Great blue heron } & Foraging & $0.90 \mathrm{~A}$ & 0.10 & $0.30 \mathrm{~B}$ & 0.15 & $1.00 \mathrm{~A}$ & 0.00 & $0.10 \mathrm{~B}$ & 0.10 & 18.39 & 3,27 & $<0.001$ \\
\hline & Reproduction & $0.67 \mathrm{~A}$ & 0.13 & $0.49 \mathrm{~A}$ & 0.15 & $0.67 \mathrm{~A}$ & 0.13 & $0.10 \mathrm{~B}$ & 0.10 & 10.21 & 3,27 & 0.001 \\
\hline & Total HSI & $0.66 \mathrm{~A}$ & 0.12 & $0.13 \mathrm{~B}$ & 0.10 & $0.66 \mathrm{~A}$ & 0.12 & $0.00 \mathrm{~B}$ & 0.00 & 17.58 & 3,27 & $<0.001$ \\
\hline Mink & Total HSI & $0.88 \mathrm{~A}$ & 0.02 & $0.79 \mathrm{BC}$ & 0.02 & $0.84 \mathrm{AB}$ & 0.02 & $0.76 \mathrm{C}$ & 0.03 & 5.21 & 3,27 & 0.006 \\
\hline \multirow[t]{3}{*}{ Muskrat } & Cover & $0.60 \mathrm{~A}$ & 0.00 & $0.60 \mathrm{~A}$ & 0.00 & $0.60 \mathrm{~A}$ & 0.00 & $0.60 \mathrm{~A}$ & 0.00 & 0.55 & 3,27 & 0.655 \\
\hline & Food & $0.66 \mathrm{~A}$ & 0.01 & $0.59 \mathrm{~B}$ & 0.02 & $0.57 \mathrm{BC}$ & 0.02 & $0.54 \mathrm{C}$ & 0.02 & 10.86 & 3,27 & $<0.001$ \\
\hline & Total HSI & $0.60 \mathrm{~A}$ & 0.00 & $0.57 \mathrm{AB}$ & 0.01 & $0.55 \mathrm{~B}$ & 0.01 & $0.53 \mathrm{~B}$ & 0.02 & 4.62 & 3,27 & 0.010 \\
\hline \multirow[t]{4}{*}{ Snapping turtle } & Food & $0.00 \mathrm{~B}$ & 0.00 & $0.02 \mathrm{~B}$ & 0.02 & $0.04 \mathrm{AB}$ & 0.02 & $0.09 \mathrm{~A}$ & 0.03 & 5.23 & 3,27 & 0.006 \\
\hline & Winter cover & $0.33 \mathrm{~A}$ & 0.02 & $0.35 \mathrm{~A}$ & 0.02 & $0.28 \mathrm{~B}$ & 0.02 & $0.32 \mathrm{~A}$ & 0.02 & 4.35 & 3,27 & 0.013 \\
\hline & Reproduction & $0.98 \mathrm{AB}$ & 0.00 & $0.98 \mathrm{~A}$ & 0.01 & $0.97 \mathrm{~B}$ & 0.00 & $0.99 \mathrm{~A}$ & 0.01 & 3.92 & 3,27 & 0.019 \\
\hline & Total HSI & $0.00 \mathrm{~B}$ & 0.00 & $0.07 \mathrm{~B}$ & 0.05 & $0.11 \mathrm{AB}$ & 0.06 & $0.21 \mathrm{~A}$ & 0.06 & 4.85 & 3,27 & 0.008 \\
\hline \multirow[t]{2}{*}{ Wood duck } & Brood-rearing & $0.09 \mathrm{~A}$ & 0.01 & $0.07 \mathrm{~A}$ & 0.01 & $0.02 \mathrm{~B}$ & 0.01 & $0.02 \mathrm{~B}$ & 0.01 & 37.02 & 3,21 & $<0.001$ \\
\hline & Winter habitat & $0.09 \mathrm{~A}$ & 0.01 & $0.10 \mathrm{~A}$ & 0.02 & $0.03 \mathrm{~B}$ & 0.01 & $0.02 \mathrm{~B}$ & 0.00 & 22.51 & 3,27 & $<0.001$ \\
\hline
\end{tabular}

${ }^{a}$ Belted kingfisher model and wood duck brood-rearing component could only be applied to 8 islands due to model parameters.

${ }^{\mathrm{b}} \mathrm{BI}=$ back channel-island side, $\mathrm{BM}=$ back channel-mainland side, $\mathrm{MI}=$ main channel-island side, $\mathrm{MM}=$ main channel-mainland side. Treatments encompassed the length of the associated island and half the width of the associated back channel.

${ }^{\mathrm{c}}$ Means in the same row followed by different letters are different $(P \leq 0.05)$. 
Table 4. Relative abundance of 5 species on back and main channels, and island and mainland sides, averaged by channel and side across years, associated with 10 islands on the Ohio River, West Virginia, USA, 2001-2002. ${ }^{\text {a }}$

\begin{tabular}{|c|c|c|c|c|c|c|c|c|c|c|c|c|c|c|c|}
\hline \multirow[b]{3}{*}{ Species } & \multirow[b]{3}{*}{ Parameter $^{\mathrm{c}}$} & \multicolumn{4}{|c|}{ Channel $^{\mathrm{b}}$} & \multirow[b]{3}{*}{$F^{\mathrm{d}}$} & \multirow[b]{3}{*}{ df } & \multirow[b]{3}{*}{$P$} & \multicolumn{4}{|c|}{ Side } & \multirow[b]{3}{*}{$F$} & \multirow[b]{3}{*}{ df } & \multirow[b]{3}{*}{$P$} \\
\hline & & \multicolumn{2}{|c|}{ Back } & \multicolumn{2}{|c|}{ Main } & & & & \multicolumn{2}{|c|}{ Island } & \multicolumn{2}{|c|}{ Mainland } & & & \\
\hline & & $\bar{x}$ & SE & $\bar{x}$ & $\mathrm{SE}$ & & & & $\bar{x}$ & SE & $\bar{x}$ & $\mathrm{SE}$ & & & \\
\hline \multirow{4}{*}{ Belted kingfisher } & Spring frequency & 0.17 & 0.05 & 0.18 & 0.06 & 0.00 & 1,21 & 0.993 & 0.15 & 0.06 & 0.19 & 0.06 & 1.53 & 1,21 & 0.230 \\
\hline & Summer density & 0.07 & 0.02 & 0.15 & 0.03 & 14.66 & 1,21 & 0.001 & 0.11 & 0.03 & 0.11 & 0.03 & 0.10 & 1,21 & 0.752 \\
\hline & Summer frequency & 0.35 & 0.09 & 0.68 & 0.10 & 8.97 & 1,21 & 0.007 & 0.48 & 0.10 & 0.54 & 0.10 & 0.25 & 1,21 & 0.622 \\
\hline & Total frequency & 0.26 & 0.05 & 0.43 & 0.06 & & & & 0.32 & 0.06 & 0.37 & 0.06 & 0.40 & 1,21 & 0.532 \\
\hline \multirow[t]{2}{*}{ Great blue heron } & Total density & 0.12 & 0.03 & 0.06 & 0.02 & 1.65 & 1,27 & 0.210 & 0.12 & 0.03 & 0.06 & 0.02 & 2.77 & 1,27 & 0.108 \\
\hline & Total frequency & 0.52 & 0.13 & 0.29 & 0.05 & 0.64 & 1,27 & 0.431 & 0.57 & 0.12 & 0.24 & 0.06 & 4.70 & 1,27 & $\mathbf{0 . 0 3 9}$ \\
\hline \multirow[t]{2}{*}{ Muskrat } & Frequency of sign and & & & & & & & & & & & & & & \\
\hline & direct observations & 0.68 & 0.05 & 0.19 & 0.04 & 48.50 & 1,27 & $<0.001$ & 0.50 & 0.08 & 0.38 & 0.07 & 2.94 & 1,27 & 0.098 \\
\hline Snapping turtle & no. captured/trap-night & 0.17 & 0.03 & 0.03 & 0.01 & 28.43 & 1,27 & $<0.001$ & 0.10 & 0.03 & 0.08 & 0.03 & 1.18 & 1,27 & 0.286 \\
\hline \multirow[t]{3}{*}{ Wood duck } & Summer density & 0.51 & 0.09 & 0.12 & 0.03 & 18.98 & 1,21 & $<0.001$ & 0.37 & 0.08 & 0.26 & 0.06 & 0.41 & 1,21 & 0.528 \\
\hline & Fall density & 0.29 & 0.09 & 0.14 & 0.12 & 10.01 & 1,27 & 0.004 & 0.18 & 0.08 & 0.26 & 0.13 & 0.02 & 1,27 & 0.893 \\
\hline & Fall frequency & 1.35 & 0.44 & 0.90 & 0.80 & 9.81 & 1,27 & 0.004 & 0.90 & 0.41 & 1.36 & 0.82 & 0.03 & 1,27 & 0.855 \\
\hline
\end{tabular}

${ }^{a}$ Belted kingfisher abundance and wood duck summer abundance were only estimated for 8 islands.

${ }^{\mathrm{b}}$ Channels encompassed an island and mainland shoreline and extended into the river from each shoreline a distance equal to half the width of the associated back channel. Sides encompassed a back channel and main channel shoreline and extended into the river from each shoreline a distance equal to half the width of the associated back channel.

${ }^{\mathrm{c}}$ Density $=$ no. birds $/ \mathrm{ha}$; frequency $=$ no. birds $/ \mathrm{km}$.

${ }^{\mathrm{d}}$ No test indicates test was not performed, due to interaction with season $(P \leq 0.05)$. 
Table 5. Relative abundance of 5 species on 4 treatments associated with 10 islands on the Ohio River, averaged by treatment across years, West Virginia, USA, 2001-2002. ${ }^{\text {a }}$

\begin{tabular}{|c|c|c|c|c|c|c|c|c|c|c|c|c|}
\hline \multirow[b]{3}{*}{ Species } & \multirow[b]{3}{*}{ Parameter $^{\mathrm{c}}$} & \multicolumn{8}{|c|}{ Treatment $^{\mathrm{b}}$} & \multirow[b]{3}{*}{$F$} & \multirow[b]{3}{*}{$\mathrm{df}$} & \multirow[b]{3}{*}{$P$} \\
\hline & & \multicolumn{2}{|c|}{$\mathrm{BI}$} & \multicolumn{2}{|l|}{$\mathrm{BM}$} & \multicolumn{2}{|c|}{ MI } & \multicolumn{2}{|c|}{ MM } & & & \\
\hline & & $\bar{x}^{\mathrm{d}}$ & SE & $x$ & $\mathrm{SE}$ & $x$ & SE & $\bar{x}$ & $\mathrm{SE}$ & & & \\
\hline \multirow[t]{2}{*}{ Belted kingfisher } & Total density & $0.05 \mathrm{~A}$ & 0.02 & $0.05 \mathrm{~A}$ & 0.02 & $0.08 \mathrm{~A}$ & 0.03 & $0.10 \mathrm{~A}$ & 0.02 & 2.34 & 3,21 & 0.102 \\
\hline & Total frequency & $0.23 \mathrm{~A}$ & 0.08 & $0.28 \mathrm{~A}$ & 0.08 & $0.40 \mathrm{~A}$ & 0.09 & $0.45 \mathrm{~A}$ & 0.09 & 1.69 & 3,21 & 0.200 \\
\hline \multirow[t]{2}{*}{ Great blue heron } & Total density & $0.17 \mathrm{~A}$ & 0.05 & $0.07 \mathrm{~A}$ & 0.03 & $0.07 \mathrm{~A}$ & 0.02 & $0.06 \mathrm{~A}$ & 0.03 & 1.78 & 3,27 & 0.174 \\
\hline & Total frequency & $0.77 \mathrm{~A}$ & 0.23 & $0.27 \mathrm{~A}$ & 0.11 & $0.36 \mathrm{~A}$ & 0.08 & $0.22 \mathrm{~A}$ & 0.06 & 2.04 & 3,27 & 0.132 \\
\hline \multirow[t]{2}{*}{ Muskrat } & Frequency of sign and & & & & & & & & & & & \\
\hline & direct observations & $0.79 \mathrm{~A}$ & 0.04 & $0.56 \mathrm{~B}$ & 0.08 & $0.20 \mathrm{C}$ & 0.07 & $0.19 \mathrm{C}$ & 0.06 & 17.96 & 3,27 & $<0.001$ \\
\hline Snapping turtle & no. captured/trap-night & $0.19 \mathrm{~A}$ & 0.05 & $0.15 \mathrm{~A}$ & 0.05 & $0.02 \mathrm{~B}$ & 0.01 & $0.03 \mathrm{~B}$ & 0.02 & 9.97 & 3,27 & $<0.001$ \\
\hline \multirow[t]{4}{*}{ Wood duck } & Summer density & $0.62 \mathrm{~A}$ & 0.14 & $0.41 \mathrm{~A}$ & 0.10 & $0.13 \mathrm{~B}$ & 0.04 & $0.11 \mathrm{~B}$ & 0.04 & 6.50 & 3,21 & 0.003 \\
\hline & Summer frequency & $3.35 \mathrm{~A}$ & 0.86 & $2.07 \mathrm{~A}$ & 0.41 & $0.79 \mathrm{~B}$ & 0.27 & $0.76 \mathrm{~B}$ & 0.35 & 4.73 & 3,21 & 0.011 \\
\hline & Fall density & $0.33 \mathrm{~A}$ & 0.15 & $0.25 \mathrm{AB}$ & 0.12 & $0.02 \mathrm{C}$ & 0.02 & $0.26 \mathrm{BC}$ & 0.24 & 3.58 & 3,27 & 0.027 \\
\hline & Fall frequency & $1.62 \mathrm{~A}$ & 0.78 & $1.08 \mathrm{AB}$ & 0.44 & $0.17 \mathrm{C}$ & 0.12 & $0.64 \mathrm{BC}$ & 1.59 & 3.49 & 3,27 & 0.029 \\
\hline
\end{tabular}

${ }^{a}$ Belted kingfisher abundance and wood duck summer abundance were only estimated for 8 islands.

${ }^{\mathrm{b}} \mathrm{BI}=$ back channel-island side, $\mathrm{BM}=$ back channel-mainland side, $\mathrm{MI}=$ main channel-island side, $\mathrm{MM}=$ main channel-mainland side. Treatments encompassed the length of the associated island and half the width of the associated back channel.

${ }^{\mathrm{c}}$ Density $=$ no. birds $/$ ha; frequency $=$ no. birds $/ \mathrm{km}$.

${ }^{\mathrm{d}}$ Means in the same row followed by different letters are different $(P \leq 0.05)$. 
Table 6. Linear regression models of relative abundance of 5 species modeled with habitat suitability index (HSI) models and model components in areas associated with 10 islands on the Ohio River, West Virginia, 2001-2002. ${ }^{\mathrm{a}}$

\begin{tabular}{|c|c|c|c|c|c|c|c|c|}
\hline Species & Variable $^{\mathrm{b}}$ & Component & Equation & $t$ & $P$ & $\mathrm{df}$ & $\mathrm{R}^{2}$ & AIC \\
\hline \multirow[t]{8}{*}{ Belted kingfisher } & Density & Water & $\mathrm{Y}=0.37$ (water component) -3.23 & 0.10 & 0.918 & 30 & 0.00 & 11.27 \\
\hline & Frequency & & $\mathrm{Y}=0.87$ (water component) -0.56 & 0.88 & 0.384 & 30 & 0.02 & -71.57 \\
\hline & Density & Cover & $Y=-1.32($ cover component $)-2.43$ & -0.65 & 0.522 & 30 & 0.01 & 10.83 \\
\hline & Frequency & & $Y=-0.31($ cover component $)-0.07$ & -0.54 & 0.590 & 30 & 0.01 & -71.06 \\
\hline & Density & Reproduction & $\mathrm{Y}=-0.38$ (reproduction component) -2.72 & -0.14 & 0.888 & 30 & 0.00 & 11.26 \\
\hline & Frequency & & $\mathrm{Y}=0.47$ (reproduction component) -0.66 & 0.63 & 0.534 & 30 & 0.01 & -71.16 \\
\hline & Density & Total HSI & $Y=-0.80(\mathrm{HSI})-2.78$ & -0.22 & 0.830 & 30 & 0.00 & 11.23 \\
\hline & Frequency & & $\mathrm{Y}=0.40(\mathrm{HSI})-0.37$ & 0.39 & 0.700 & 30 & 0.00 & -70.91 \\
\hline \multirow[t]{6}{*}{ Great blue heron } & Density & Foraging & $Y=-0.23$ (foraging component) -2.66 & -0.61 & 0.547 & 34 & 0.01 & 9.00 \\
\hline & Frequency & & $\mathrm{Y}=0.11$ (foraging component) -1.27 & 0.33 & 0.747 & 34 & 0.00 & 2.90 \\
\hline & Density & Reproduction & $\mathrm{Y}=0.12$ (reproduction component) -2.85 & 0.29 & 0.773 & 34 & 0.00 & 9.30 \\
\hline & Frequency & & $\mathrm{Y}=0.79$ (reproduction component) -1.56 & 2.23 & 0.032 & 34 & 0.13 & -1.90 \\
\hline & Density & HSI & $\mathrm{Y}=0.38(\mathrm{HSI})-3.10$ & 0.74 & 0.465 & 34 & 0.02 & 20.53 \\
\hline & Frequency & & $\mathrm{Y}=0.89(\mathrm{HSI})-1.51$ & 2.40 & 0.022 & 34 & 0.14 & -2.64 \\
\hline \multirow[t]{3}{*}{ Muskrat } & Relative abundance & Cover & $Y=-33.89($ cover component $)+19.16$ & -0.94 & 0.355 & 38 & 0.02 & 5.78 \\
\hline & Relative abundance & Food & $Y=0.74($ food component $)+0.79$ & 4.67 & $<0.001$ & 38 & 0.36 & -203.42 \\
\hline & Relative abundance & HSI & $\mathrm{Y}=3.73(\mathrm{HSI})-2.23$ & 3.62 & 0.001 & 38 & 0.26 & -87.85 \\
\hline \multirow[t]{4}{*}{ Snapping turtle } & Relative abundance & Food & $Y=-1.60($ food component $)-1.74$ & -1.20 & 0.240 & 38 & 0.04 & -40.91 \\
\hline & Relative abundance & Winter cover & $Y=2.90($ winter cover component $)-2.73$ & 2.21 & $\mathbf{0 . 0 3 3}$ & 38 & 0.11 & -44.27 \\
\hline & Relative abundance & Reproduction & $\mathrm{Y}=0.07$ (reproduction component) -1.88 & 0.02 & 0.988 & 38 & 0.00 & -39.43 \\
\hline & Relative abundance & HSI & $\mathrm{Y}=-0.71(\mathrm{HSI})-1.74$ & -1.25 & 0.219 & 38 & 0.04 & -41.04 \\
\hline \multirow[t]{4}{*}{ Wood duck } & Density & Brood-rearing & $\mathrm{Y}=13.76$ (brood-rearing component $)-1.80$ & 5.72 & $<0.001$ & 30 & 0.52 & -37.89 \\
\hline & Frequency & & $\mathrm{Y}=9.04($ brood-rearing component $)+0.11$ & 2.95 & 0.006 & 30 & 0.22 & -22.35 \\
\hline & Density & Winter cover & $Y=7.38$ (winter cover component) -4.10 & 1.28 & 0.210 & 34 & 0.04 & 48.59 \\
\hline & Frequency & & $\mathrm{Y}=8.07$ (winter cover component) -3.40 & 1.00 & 0.325 & 34 & 0.03 & 72.87 \\
\hline
\end{tabular}

${ }^{a}$ Belted kingfisher model and wood duck brood-rearing component could only be used with 8 islands due to model parameters. 


\section{Table 6. Continued.}

${ }^{\mathrm{b}}$ Density $=$ no. birds $/$ ha, frequency $=$ no. birds $/ \mathrm{km}$; muskrat relative abundance $=$ frequency of sign and direct observations; snapping turtle relative abundance $=$ no. captured/trap-night. 
Table 7. Backwards selection multiple regression models of relative abundance of 5 species modeled with habitat suitability index (HSI) model variables in areas associated with 10 islands on the Ohio River, West Virginia, 2001-2002.

\begin{tabular}{|c|c|c|c|c|c|c|c|c|}
\hline Species & Variable $^{\mathrm{b}}$ & Component & Equation & $F$ & $P$ & $\mathrm{R}^{2}$ & $\mathrm{df}$ & AIC \\
\hline \multirow[t]{2}{*}{ Belted kingfisher } & Density & Total HSI & $\begin{array}{l}Y=-2.15(\text { water transparency })+2.83(\% \text { riffles }) \\
-1.12\end{array}$ & 13.34 & $<0.001$ & 0.48 & 2,29 & -7.59 \\
\hline & Frequency & Total HSI & $\begin{array}{l}Y=-0.39(\text { water transparency })+1.20(\% \text { riffles }) \\
+0.13\end{array}$ & 6.57 & 0.004 & 0.31 & 2,29 & -80.71 \\
\hline \multirow[t]{2}{*}{ Great blue heron } & Density & Total HSI & $\begin{array}{l}Y=-0.02 \text { (proximity of potential to active nests) } \\
-2.68\end{array}$ & 1.62 & 0.212 & 0.05 & 1,33 & 6.23 \\
\hline & Frequency & Total HSI & $\begin{array}{l}\text { If SIV5 }=0, Y=-0.59-0.02 \text { (proximity of } \\
\text { potential to active nests) }-0.56 \\
\text { If SIV } 5=1, Y=-0.02 \text { (proximity of potential to } \\
\text { active nests) }-0.56\end{array}$ & 4.40 & 0.020 & 0.22 & 2,32 & -17.02 \\
\hline Muskrat & Relative abundance & Total HSI & $Y=0.01(\%$ herbaceous canopy cover $)-0.70$ & 27.05 & $<0.001$ & 0.42 & 1,38 & -113.35 \\
\hline Snapping turtle & Relative abundance & Total HSI & $Y=0.02(\%$ silt $)-1.66$ & 5.32 & 0.027 & 0.12 & 1,38 & -89.46 \\
\hline \multirow[t]{4}{*}{ Wood duck } & Density & Brood-rearing & $\mathrm{Y}=0.28($ brood cover $)-1.81$ & 36.29 & $<0.001$ & 0.55 & 1,30 & -39.67 \\
\hline & Frequency & & $\mathrm{Y}=0.19($ brood cover $)+0.10$ & 9.97 & 0.004 & 0.25 & 1,30 & -23.39 \\
\hline & Density & Winter cover & $Y=0.48($ winter cover $)-9.58$ & 1.77 & 0.192 & 0.05 & 1,34 & 131.14 \\
\hline & Frequency & & $Y=0.34($ winter cover $)-6.36$ & 1.17 & 0.250 & 0.04 & 1,34 & 116.54 \\
\hline
\end{tabular}

\footnotetext{
${ }^{a}$ Belted kingfisher model and wood duck brood-rearing component could only be used with 8 islands due to model parameters.

${ }^{b}$ Density $=$ no. birds $/$ ha, frequency $=$ no. birds $/ \mathrm{km}$; muskrat relative abundance $=$ frequency of sign and direct observations; snapping turtle relative abundance $=$ no. turtles captured/trap-night.
} 
APPENDICES 
Appendix A. Island area (ha), area and length $(\mathrm{km})$ of 4 treatments $^{\mathrm{a}}$, and width $(\mathrm{km})$ of back $(\mathrm{BC})$ and main $(\mathrm{MC}) \mathrm{channels}^{\mathrm{b}}$, associated with 10 islands on the Ohio River, West Virginia, USA.

\begin{tabular}{|c|c|c|c|c|c|c|c|c|c|c|c|}
\hline \multirow[b]{2}{*}{ Island } & \multicolumn{5}{|c|}{ Area } & \multicolumn{4}{|c|}{ Length } & \multicolumn{2}{|c|}{ Width } \\
\hline & Island & $\mathrm{BI}$ & $\mathrm{BM}$ & MI & MM & $\mathrm{BI}$ & $\mathrm{BM}$ & MI & $\mathrm{MM}$ & $\mathrm{BC}$ & $\mathrm{MC}$ \\
\hline Buckley & 71.32 & 38.61 & 39.87 & 46.13 & 45.59 & 4.16 & 4.09 & 4.38 & 4.51 & 0.18 & 0.24 \\
\hline Buffington & 57.97 & 7.54 & 6.51 & 9.06 & 9.79 & 1.74 & 1.75 & 1.76 & 1.80 & 0.08 & 0.37 \\
\hline Captina & 5.43 & 0.96 & 0.92 & 0.89 & 0.84 & 0.63 & 0.63 & 0.64 & 0.51 & 0.03 & 0.42 \\
\hline Middle & 95.58 & 8.01 & 7.84 & 7.64 & 9.66 & 3.71 & 3.72 & 3.48 & 3.59 & 0.05 & 0.37 \\
\hline Mill Creek & 9.32 & 2.41 & 2.72 & 2.33 & 2.28 & 0.86 & 0.84 & 0.81 & 0.79 & 0.06 & 0.37 \\
\hline Muskingum & 40.48 & 38.91 & 39.00 & 34.53 & 34.66 & 3.22 & 3.30 & 3.08 & 3.00 & 0.22 & 0.31 \\
\hline Neal & 48.50 & 14.95 & 13.30 & 13.85 & 13.62 & 2.01 & 2.04 & 1.98 & 2.01 & 0.14 & 0.34 \\
\hline Paden & 34.08 & 5.38 & 5.31 & 6.43 & 7.03 & 1.72 & 1.72 & 1.77 & 1.92 & 0.07 & 0.33 \\
\hline Wells & 18.83 & 6.68 & 5.95 & 6.40 & 6.98 & 1.09 & 1.09 & 1.08 & 1.06 & 0.12 & 0.38 \\
\hline Williamson & 53.91 & 14.61 & 14.26 & 16.95 & 17.61 & 2.19 & 2.20 & 2.20 & 2.22 & 0.14 & 0.31 \\
\hline
\end{tabular}

${ }^{a}$ BI: back channel-island side; BM: back channel-mainland side; MI: main channel-island side; MM: main channel-mainland side. Treatments encompassed the length of the associated island and one-half of the width of the associated back channel.

${ }^{\mathrm{b}}$ Total width across river channel. 
Appendix B. Land cover types within $300 \mathrm{~m}$ of the water's edge along the back channel and main channel mainland shorelines, based on a 1:100,000 scale, associated with 10 islands on the Ohio River, West Virginia, USA (U. S. Geological Survey 2002).

\begin{tabular}{|c|c|c|c|c|}
\hline Island & Mainland shoreline & Land cover & Area (ha) & Percent \\
\hline \multirow[t]{22}{*}{ Buckley } & \multirow[t]{12}{*}{ Back channel } & Barren land-mining, construction & 0.90 & 0.82 \\
\hline & & Floodplain forest & 7.47 & 6.84 \\
\hline & & Hardwood/conifer forest & 1.80 & 1.65 \\
\hline & & Herbaceous wetland & 1.35 & 1.24 \\
\hline & & Intensive urban & 6.57 & 6.02 \\
\hline & & Light intensity urban & 13.77 & 12.61 \\
\hline & & Major roads & 1.17 & 1.07 \\
\hline & & Mesophytic hardwood forest & 0.27 & 0.25 \\
\hline & & Moderate intensity urban & 4.05 & 3.71 \\
\hline & & Oak dominant forest & 8.73 & 8.00 \\
\hline & & Pasture/grassland & 56.16 & 51.44 \\
\hline & & Row crop/agriculture & 6.93 & 6.35 \\
\hline & \multirow[t]{10}{*}{ Main channel } & Barren land-mining, construction & 4.50 & 3.22 \\
\hline & & Conifer plantation & 0.27 & 0.19 \\
\hline & & Hardwood/conifer forest & 0.63 & 0.45 \\
\hline & & Herbaceous wetland & 6.66 & 4.76 \\
\hline & & Intensive urban & 21.06 & 15.06 \\
\hline & & Light intensity urban & 3.87 & 2.77 \\
\hline & & Moderate intensity urban & 12.78 & 9.14 \\
\hline & & Oak dominant forest & 1.08 & 0.77 \\
\hline & & Pasture/grassland & 72.00 & 51.48 \\
\hline & & Row crop/agriculture & 17.01 & 12.16 \\
\hline \multirow[t]{12}{*}{ Buffington } & \multirow[t]{9}{*}{ Back channel } & Floodplain forest & 1.17 & 2.27 \\
\hline & & Hardwood/conifer forest & 1.17 & 2.27 \\
\hline & & Herbaceous wetland & 3.33 & 6.46 \\
\hline & & Intensive urban & 0.09 & 0.17 \\
\hline & & Light intensity urban & 0.63 & 1.22 \\
\hline & & Moderate intensity urban & 1.26 & 2.44 \\
\hline & & Oak dominant forest & 6.12 & 11.87 \\
\hline & & Pasture/grassland & 28.62 & 55.50 \\
\hline & & Row crop/agriculture & 9.18 & 17.80 \\
\hline & \multirow[t]{3}{*}{ Main channel } & Barren land-mining, construction & 0.90 & 1.78 \\
\hline & & Conifer plantation & 3.96 & 7.82 \\
\hline & & Floodplain forest & 7.74 & 15.28 \\
\hline
\end{tabular}


Appendix B. Continued.

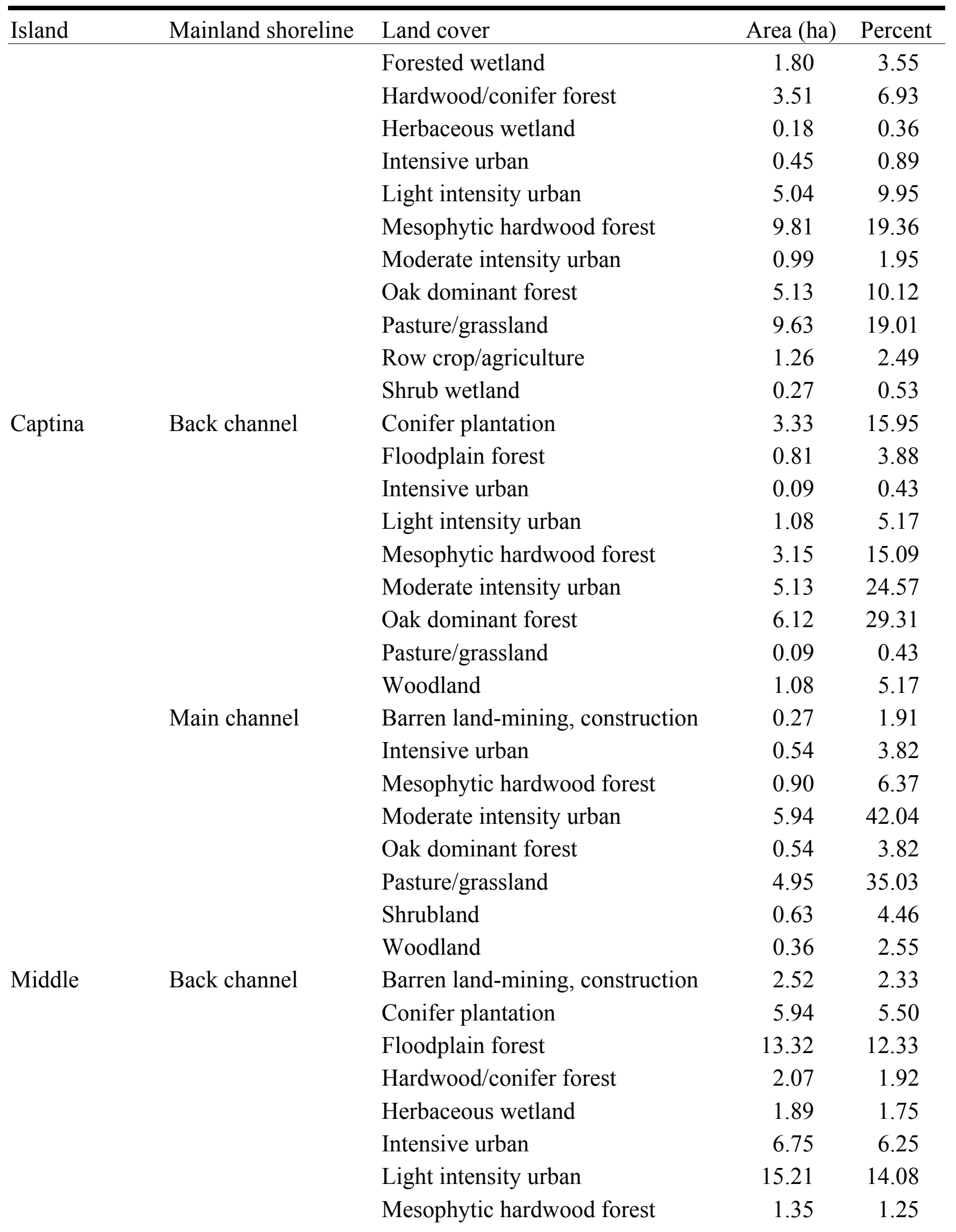


Appendix B. Continued.

\begin{tabular}{|c|c|c|c|c|}
\hline Island & Mainland shoreline & Land cover & Area (ha) & Percent \\
\hline & & Moderate intensity urban & 14.76 & 13.67 \\
\hline & & Oak dominant forest & 5.13 & 4.75 \\
\hline & & Pasture/grassland & 27.45 & 25.42 \\
\hline & & Populated areas & 0.90 & 0.83 \\
\hline & & Row crop/agriculture & 9.99 & 9.25 \\
\hline & & Shrub wetland & 0.72 & 0.67 \\
\hline & Main channel & Barren land-mining, construction & 2.61 & 2.60 \\
\hline & & Conifer plantation & 1.44 & 1.43 \\
\hline & & Hardwood/conifer forest & 8.01 & 7.97 \\
\hline & & Herbaceous wetland & 10.35 & 10.30 \\
\hline & & Intensive urban & 1.35 & 1.34 \\
\hline & & Light intensity urban & 3.42 & 3.40 \\
\hline & & Mesophytic hardwood forest & 1.44 & 1.43 \\
\hline & & Moderate intensity urban & 0.45 & 0.45 \\
\hline & & Oak dominant forest & 34.83 & 34.65 \\
\hline & & Pasture/grassland & 32.22 & 32.05 \\
\hline & & Row crop/agriculture & 4.41 & 4.39 \\
\hline \multirow[t]{19}{*}{ Mill Creek } & Back channel & Conifer plantation & 4.77 & 18.15 \\
\hline & & Cove hardwood forest & 6.03 & 22.95 \\
\hline & & Floodplain forest & 5.49 & 20.89 \\
\hline & & Hardwood/conifer forest & 0.54 & 2.05 \\
\hline & & Light intensity urban & 4.14 & 15.75 \\
\hline & & Moderate intensity urban & 0.09 & 0.34 \\
\hline & & Oak dominant forest & 0.36 & 1.37 \\
\hline & & Pasture/grassland & 2.07 & 7.88 \\
\hline & & Row crop/agriculture & 2.79 & 10.62 \\
\hline & Main channel & Barren land-mining, construction & 1.08 & 4.90 \\
\hline & & Hardwood/conifer forest & 0.36 & 1.63 \\
\hline & & Herbaceous wetland & 2.88 & 13.06 \\
\hline & & Intensive urban & 0.18 & 0.82 \\
\hline & & Light intensity urban & 0.72 & 3.27 \\
\hline & & Moderate intensity urban & 1.17 & 5.31 \\
\hline & & Oak dominant forest & 1.53 & 6.94 \\
\hline & & Pasture/grassland & 12.60 & 57.14 \\
\hline & & Row crop/agriculture & 1.53 & 6.94 \\
\hline & Back channel & Barren land-mining, construction & 1.53 & 1.54 \\
\hline
\end{tabular}


Appendix B. Continued.

\begin{tabular}{|c|c|c|c|c|}
\hline Island & Mainland shoreline & Land cover & Area (ha) & Percent \\
\hline & & Conifer plantation & 0.81 & 0.81 \\
\hline & & Floodplain forest & 24.93 & 25.07 \\
\hline & & Forested wetland & 0.45 & 0.45 \\
\hline & & Hardwood/conifer forest & 0.27 & 0.27 \\
\hline & & Herbaceous wetland & 0.72 & 0.72 \\
\hline & & Intensive urban & 0.45 & 0.45 \\
\hline & & Light intensity urban & 1.53 & 1.54 \\
\hline & & Mesophytic hardwood forest & 9.99 & 10.05 \\
\hline & & Moderate intensity urban & 1.89 & 1.90 \\
\hline & & Oak dominant forest & 2.16 & 2.17 \\
\hline & & Pasture/grassland & 37.35 & 37.56 \\
\hline & & Row crop/agriculture & 14.76 & 14.84 \\
\hline & & Shrub wetland & 2.61 & 2.62 \\
\hline & Main channel & Barren land-mining, construction & 14.31 & 19.51 \\
\hline & & Conifer plantation & 0.27 & 0.37 \\
\hline & & Hardwood/conifer forest & 2.16 & 2.94 \\
\hline & & Herbaceous wetland & 9.00 & 12.27 \\
\hline & & Intensive urban & 19.62 & 26.75 \\
\hline & & Light intensity urban & 6.03 & 8.22 \\
\hline & & Mesophytic hardwood forest & 0.09 & 0.12 \\
\hline & & Moderate intensity urban & 2.07 & 2.82 \\
\hline & & Oak dominant forest & 2.61 & 3.56 \\
\hline & & Pasture/grassland & 15.66 & 21.35 \\
\hline & & Row crop/agriculture & 1.53 & 2.09 \\
\hline \multirow[t]{12}{*}{ Neal } & Back channel & Barren land-mining, construction & 0.81 & 1.34 \\
\hline & & Floodplain forest & 3.33 & 5.50 \\
\hline & & Forested wetland & 3.69 & 6.09 \\
\hline & & Herbaceous wetland & 1.08 & 1.78 \\
\hline & & Intensive urban & 23.31 & 38.48 \\
\hline & & Light intensity urban & 11.97 & 19.76 \\
\hline & & Moderate intensity urban & 3.96 & 6.54 \\
\hline & & Pasture/grassland & 11.52 & 19.02 \\
\hline & & Row crop/agriculture & 0.90 & 1.49 \\
\hline & Main channel & Barren land-mining, construction & 4.59 & 7.96 \\
\hline & & Conifer plantation & 0.27 & 0.47 \\
\hline & & Hardwood/conifer forest & 1.17 & 2.03 \\
\hline
\end{tabular}


Appendix B. Continued.

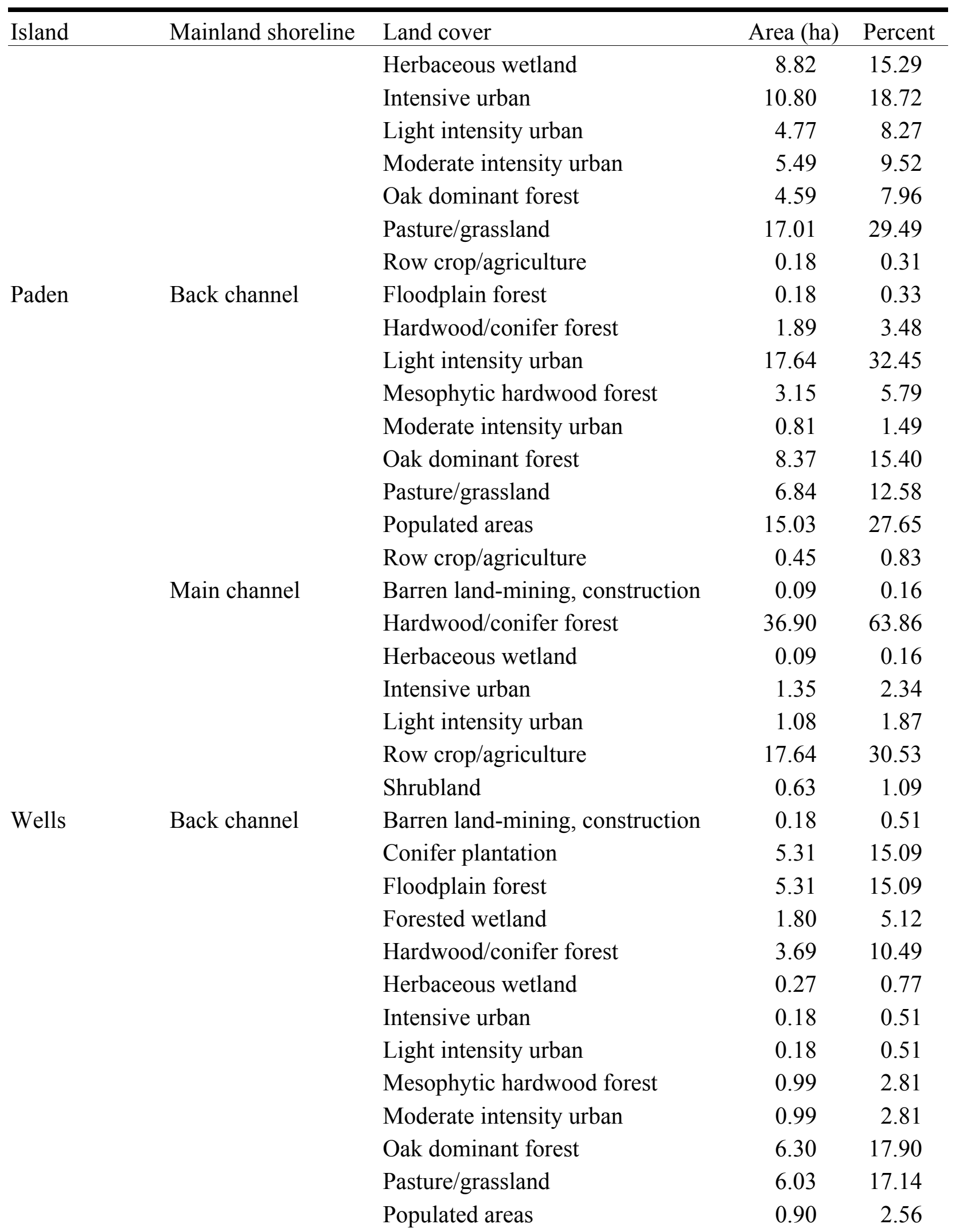


Appendix B. Continued.

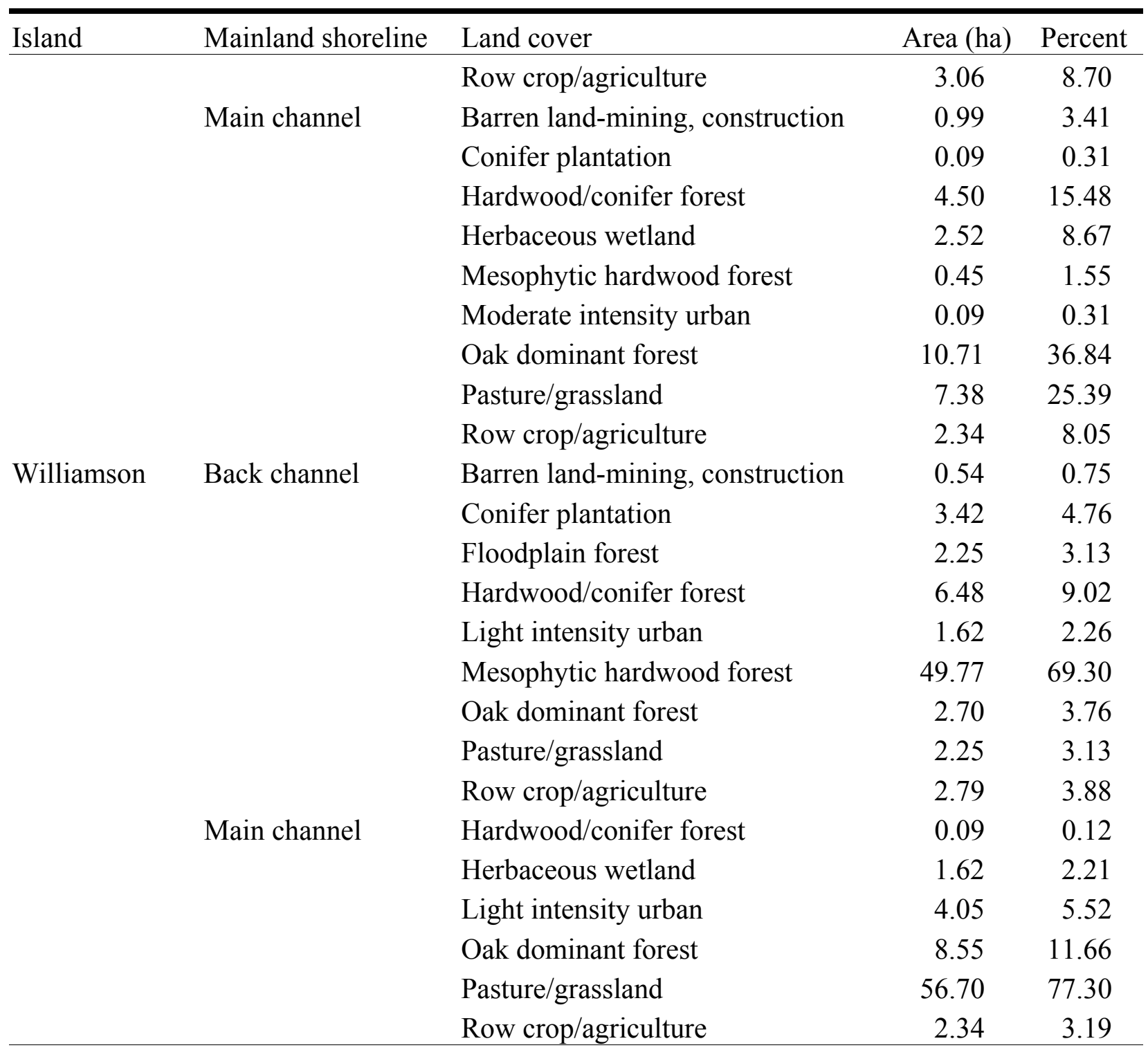


Appendix C. Density (no. birds/ha), frequency (no. birds $/ \mathrm{km}$ ), species richness (no. species/treatment) and diversity (Shannon \& Weaver 1949) of all waterbirds, and density and frequency of waterfowl, wading birds and 5 waterbird species encountered on island and mainland sides, averaged by side across years, associated with 10 islands on the Ohio River, West Virginia, USA, 2001-2002.

\begin{tabular}{|c|c|c|c|c|c|c|c|c|}
\hline \multirow[b]{3}{*}{ Variable } & \multirow[b]{3}{*}{ Season ${ }^{b}$} & \multirow[b]{3}{*}{ Measure } & \multicolumn{4}{|c|}{ Side $^{\mathrm{a}}$} & \multirow[b]{3}{*}{$F_{1,27}{ }^{\mathrm{c}}$} & \multirow[b]{3}{*}{$P$} \\
\hline & & & \multicolumn{2}{|c|}{ Island } & \multicolumn{2}{|c|}{ Mainland } & & \\
\hline & & & $\bar{x}$ & $\mathrm{SE}$ & $\bar{x}$ & $\mathrm{SE}$ & & \\
\hline \multirow[t]{12}{*}{ All waterbirds ${ }^{\mathrm{d}}$} & Spring & Density & 1.75 & 0.26 & 1.09 & 0.19 & 4.55 & 0.042 \\
\hline & & Frequency & 9.20 & 1.43 & 4.57 & 0.57 & 4.85 & 0.036 \\
\hline & Summer & Density & 1.57 & 0.50 & 2.82 & 0.67 & 2.38 & 0.135 \\
\hline & & Frequency & 6.50 & 1.48 & 10.70 & 2.38 & 1.88 & 0.181 \\
\hline & Fall & Density & 0.69 & 0.11 & 0.98 & 0.29 & 0.10 & 0.749 \\
\hline & & Frequency & 2.90 & 0.50 & 3.38 & 0.98 & 0.58 & 0.453 \\
\hline & Winter & Density & 0.83 & 0.29 & 1.34 & 0.52 & 0.22 & 0.644 \\
\hline & & Frequency & 4.29 & 1.62 & 5.42 & 1.98 & 0.13 & 0.718 \\
\hline & Total & Density & 1.26 & 0.17 & 1.59 & 0.24 & & \\
\hline & & Frequency & 5.93 & 0.68 & 6.10 & 0.84 & & \\
\hline & Total & Richness & 2.43 & 0.14 & 2.15 & 0.12 & 1.88 & 0.182 \\
\hline & Total & Diversity & 0.64 & 0.04 & 0.55 & 0.04 & 1.74 & 0.199 \\
\hline \multirow[t]{2}{*}{ Waterfowl $^{\mathrm{e}}$} & Total & Density & 0.95 & 0.16 & 1.18 & 0.22 & 0.13 & 0.722 \\
\hline & & Frequency & 4.65 & 0.64 & 4.79 & 0.80 & 0.07 & 0.795 \\
\hline \multirow[t]{14}{*}{ Wading birds ${ }^{f}$} & Spring & Density & 0.09 & 0.05 & 0.01 & 0.01 & & \\
\hline & & Frequency & 0.60 & 0.32 & 0.08 & 0.05 & & \\
\hline & Spring 2001 & Density & 0.09 & 0.05 & 0.01 & 0.01 & 5.40 & 0.028 \\
\hline & & Frequency & 0.60 & 0.32 & 0.08 & 0.05 & 5.43 & 0.028 \\
\hline & Spring 2002 & Density & 0.08 & 0.03 & 0.06 & 0.03 & 1.44 & 0.241 \\
\hline & & Frequency & 0.54 & 0.19 & 0.32 & 0.22 & 1.64 & 0.211 \\
\hline & Summer & Density & 0.21 & 0.05 & 0.29 & 0.09 & 0.00 & 0.981 \\
\hline & & Frequency & 0.85 & 0.19 & 1.01 & 0.18 & 0.09 & 0.760 \\
\hline & Fall & Density & 0.27 & 0.06 & 0.30 & 0.21 & 12.89 & 0.001 \\
\hline & & Frequency & 0.94 & 0.13 & 0.74 & 0.36 & 15.77 & $<0.001$ \\
\hline & Winter & Density & 0.14 & 0.04 & 0.06 & 0.02 & 3.04 & 0.093 \\
\hline & & Frequency & 0.95 & 0.39 & 0.29 & 0.08 & 0.58 & 0.454 \\
\hline & Total & Density & 0.18 & 0.03 & 0.19 & 0.06 & & \\
\hline & & Frequency & 0.81 & 0.10 & 0.60 & 0.12 & & \\
\hline \multirow[t]{2}{*}{ Belted kingfisher } & Total & Density & 0.10 & 0.02 & 0.18 & 0.04 & 4.74 & 0.038 \\
\hline & & Frequency & 0.34 & 0.04 & 0.51 & 0.08 & 3.76 & 0.630 \\
\hline Canada goose & Total & Density & 0.47 & 0.13 & 0.77 & 0.18 & 0.01 & 0.924 \\
\hline
\end{tabular}


Appendix C. Continued.

\begin{tabular}{|c|c|c|c|c|c|c|c|c|}
\hline \multirow[b]{3}{*}{ Variable } & \multirow[b]{3}{*}{ Season ${ }^{b}$} & \multirow[b]{3}{*}{ Measure } & \multicolumn{4}{|c|}{ Side } & \multirow[b]{3}{*}{$F_{1,27}{ }^{\mathrm{c}}$} & \multirow[b]{3}{*}{$P$} \\
\hline & & & \multicolumn{2}{|c|}{ Island } & \multicolumn{2}{|c|}{ Mainland } & & \\
\hline & & & $\bar{x}$ & $\mathrm{SE}$ & $\bar{x}$ & $\mathrm{SE}$ & & \\
\hline \multirow{3}{*}{ Great blue heron } & \multirow{3}{*}{ Total } & Frequency & 2.31 & 0.45 & 3.10 & 0.72 & 0.06 & 0.808 \\
\hline & & Density & 0.14 & 0.02 & 0.06 & 0.02 & 11.94 & 0.002 \\
\hline & & Frequency & 0.67 & 0.10 & 0.26 & 0.05 & 11.36 & 0.002 \\
\hline \multirow[t]{2}{*}{ Mallard } & \multirow[t]{2}{*}{ Total } & Density & 0.11 & 0.04 & 0.17 & 0.06 & 0.02 & 0.886 \\
\hline & & Frequency & 0.44 & 0.10 & 0.48 & 0.12 & 0.02 & 0.891 \\
\hline \multirow[t]{2}{*}{ Wood duck } & \multirow[t]{2}{*}{ Total } & Density & 0.28 & 0.05 & 0.18 & 0.04 & 1.87 & 0.183 \\
\hline & & Frequency & 1.37 & 0.25 & 0.91 & 0.25 & 1.73 & 0.199 \\
\hline
\end{tabular}

${ }^{a}$ Island side: back channel-island side and main channel-island side treatments; mainland side: back channel-mainland side and main channel-mainland side treatments. Each treatment encompassed the length of the associated island and one-half of the width of the associated back channel.

${ }^{\mathrm{b}}$ Spring: 21 March-7 April 2001, 23-25 March 2002; summer: 14-28 May, 11-27 June 2002, 16 25 May, 17-26 June, 17 July-13 August 2002; fall: 10-16 November 2001, 28 September-6 October 2002; winter: 26-28 January 2002.

${ }^{\mathrm{c}}$ No test indicates test was not performed, due to interaction with year or season $(P \leq 0.05)$.

${ }^{\mathrm{d}}$ Divers, grebes, cormorants, waterfowl, herons, coots, gulls and terns, sandpipers and associates, and belted kingfishers

${ }^{\mathrm{e}}$ Ducks and geese

${ }^{\mathrm{f}}$ Herons, sandpipers, and killdeer 
Appendix D. Density (no. birds/ha) of all waterbirds, waterfowl, wading birds, and 5 waterbird species encountered on back and main channels, averaged by channel across years, associated with 10 islands on the Ohio River, West Virginia, USA, 2001-2002.

\begin{tabular}{|c|c|c|c|c|c|c|c|}
\hline \multirow[b]{3}{*}{ Variable } & \multirow[b]{3}{*}{ Season $^{\mathrm{b}}$} & \multicolumn{4}{|c|}{ Channel $^{\mathrm{a}}$} & \multirow[b]{3}{*}{$F_{1,27}{ }^{\mathrm{c}}$} & \multirow[b]{3}{*}{$P$} \\
\hline & & \multicolumn{2}{|c|}{ Back } & \multicolumn{2}{|c|}{ Main } & & \\
\hline & & $\bar{x}$ & SE & $\bar{x}$ & $\mathrm{SE}$ & & \\
\hline All waterbirds ${ }^{\mathrm{d}}$ & Total & 1.54 & 0.18 & 1.31 & 0.23 & 6.96 & 0.014 \\
\hline Waterfowl $^{\mathrm{e}}$ & Total & 1.26 & 0.18 & 0.87 & 0.20 & 13.21 & 0.001 \\
\hline Wading birds ${ }^{\mathrm{f}}$ & Total & 0.47 & 0.03 & 0.20 & 0.06 & 1.22 & 0.279 \\
\hline Belted kingfisher & Total & 0.08 & 0.02 & 0.19 & 0.04 & 10.98 & 0.003 \\
\hline \multirow[t]{5}{*}{ Canada goose } & Spring & 0.62 & 0.14 & 0.56 & 0.11 & 0.00 & 0.978 \\
\hline & Summer & 0.83 & 0.32 & 1.51 & 0.62 & 1.27 & 0.269 \\
\hline & Fall & 0.03 & 0.03 & 0.09 & 0.06 & 0.22 & 0.645 \\
\hline & Winter & 1.10 & 0.48 & 0.32 & 0.17 & 2.42 & 0.131 \\
\hline & Total & 0.58 & 0.12 & 0.66 & 0.18 & & \\
\hline Great blue heron & Total & 0.12 & 0.02 & 0.08 & 0.01 & 1.30 & 0.264 \\
\hline \multirow[t]{5}{*}{ Mallard } & Spring & 0.31 & 0.13 & 0.05 & 0.02 & 5.31 & 0.029 \\
\hline & Summer & 0.33 & 0.17 & 0.09 & 0.02 & 0.07 & 0.792 \\
\hline & Fall & 0.10 & 0.08 & 0.02 & 0.01 & 1.28 & 0.268 \\
\hline & Winter & 0.18 & 0.09 & 0.01 & 0.01 & 9.23 & 0.005 \\
\hline & Total & 0.24 & 0.06 & 0.05 & 0.01 & & \\
\hline Wood duck & Total & 0.36 & 0.05 & 0.10 & 0.04 & 32.30 & $<0.001$ \\
\hline
\end{tabular}

${ }^{a}$ Back channel: back channel-island side and back channel-mainland side treatments; main channel: main channel-island side and main channel-mainland side treatments. Each treatment encompassed the length of the associated island and one-half of the width of the associated back channel.

${ }^{b}$ Spring: 21 March-7 April 2001, 23-25 March 2002; summer: 14-28 May, 11-27 June 2002, 1625 May, 17-26 June, 17 July-13 August 2002; fall: 10-16 November 2001, 28 September-6

October 2002; winter: 26-28 January 2002.

${ }^{\mathrm{c}}$ No test indicates test was not performed, due to interaction with season $(P \leq 0.05)$.

${ }^{\mathrm{d}}$ Divers, grebes, cormorants, waterfowl, herons, coots, gulls and terns, sandpipers and associates, and belted kingfishers

${ }^{\mathrm{e}}$ Ducks and geese

${ }^{\mathrm{f}}$ Herons, sandpipers, and killdeer 
Appendix E. Density (no. birds/ha) of all waterbirds, waterfowl, wading birds, and 5 waterbird species encountered in 4 treatments ( $\mathrm{BI}=$ back channel-island side, $\mathrm{BM}=$ back channel-mainland side, $\mathrm{MI}=$ main channel-island side, $\mathrm{MM}=$ main channel-mainland side), averaged by treatment across years, associated with 10 islands on the Ohio River, West Virginia, USA, 2001-2002.

\begin{tabular}{|c|c|c|c|c|c|c|c|c|c|c|c|}
\hline \multirow[b]{3}{*}{ Variable } & \multirow[b]{3}{*}{ Season $^{\mathrm{b}}$} & \multicolumn{8}{|c|}{ Treatment $^{\mathrm{a}}$} & \multirow[b]{3}{*}{$F_{3,27}$} & \multirow[b]{3}{*}{$P$} \\
\hline & & \multicolumn{2}{|c|}{$\mathrm{BI}$} & \multicolumn{2}{|c|}{$\mathrm{BM}$} & \multicolumn{2}{|c|}{ MI } & \multicolumn{2}{|c|}{ MM } & & \\
\hline & & $\bar{x}^{\mathrm{c}}$ & SE & $\bar{x}$ & SE & $\bar{x}$ & $\mathrm{SE}$ & $\bar{x}$ & $\mathrm{SE}$ & & \\
\hline All waterbirds ${ }^{\mathrm{d}}$ & Total & $1.39 \mathrm{~A}$ & 0.17 & $1.69 \mathrm{~A}$ & 0.32 & $1.14 \mathrm{~A}$ & 0.30 & $1.49 \mathrm{~A}$ & 0.35 & 2.36 & 0.094 \\
\hline Waterfowl ${ }^{\mathrm{e}}$ & Total & $1.10 \mathrm{~A}$ & 0.17 & $1.42 \mathrm{~A}$ & 0.31 & $0.81 \mathrm{~B}$ & 0.28 & $0.93 \mathrm{~B}$ & 0.30 & 4.52 & 0.011 \\
\hline \multirow[t]{5}{*}{ Wading birds ${ }^{\mathrm{f}}$} & Spring & $0.13 \mathrm{~A}$ & 0.06 & $0.05 \mathrm{~A}$ & 0.03 & $0.04 \mathrm{~A}$ & 0.02 & $0.02 \mathrm{~A}$ & 0.01 & 2.68 & 0.067 \\
\hline & Summer & $0.24 \mathrm{~A}$ & 0.08 & $0.31 \mathrm{~A}$ & 0.12 & $0.18 \mathrm{~A}$ & 0.05 & $0.27 \mathrm{~A}$ & 0.12 & 0.27 & 0.844 \\
\hline & Fall & $0.22 \mathrm{~A}$ & 0.05 & $0.08 \mathrm{C}$ & 0.05 & $0.33 \mathrm{AB}$ & 0.12 & $0.52 \mathrm{BC}$ & 0.42 & 4.74 & 0.009 \\
\hline & Winter & $0.24 \mathrm{~A}$ & 0.08 & $0.04 \mathrm{~B}$ & 0.02 & $0.03 \mathrm{~B}$ & 0.02 & $0.07 \mathrm{~B}$ & 0.03 & 5.10 & 0.006 \\
\hline & Total & $0.20 \mathrm{~A}$ & 0.03 & $0.13 \mathrm{~B}$ & 0.04 & $0.16 \mathrm{~B}$ & 0.04 & $0.24 \mathrm{~B}$ & 0.12 & & \\
\hline Belted kingfisher & Total & $0.07 \mathrm{~A}$ & 0.02 & $0.10 \mathrm{~A}$ & 0.04 & $0.12 \mathrm{~A}$ & 0.03 & $0.26 \mathrm{~B}$ & 0.07 & 5.84 & 0.003 \\
\hline Canada goose & Total & $0.33 \mathrm{~A}$ & 0.09 & $0.83 \mathrm{~A}$ & 0.23 & $0.62 \mathrm{~A}$ & 0.24 & $0.71 \mathrm{~A}$ & 0.28 & 1.21 & 0.324 \\
\hline Great blue heron & Total & $0.17 \mathrm{~A}$ & 0.03 & $0.07 \mathrm{~B}$ & 0.02 & $0.10 \mathrm{~B}$ & 0.02 & $0.06 \mathrm{~B}$ & 0.02 & 5.35 & 0.005 \\
\hline \multirow[t]{5}{*}{ Mallard } & Spring & $0.38 \mathrm{~A}$ & 0.22 & $0.24 \mathrm{~A}$ & 0.14 & $0.05 \mathrm{~A}$ & 0.03 & $0.05 \mathrm{~A}$ & 0.02 & 2.76 & 0.062 \\
\hline & Summer & $0.16 \mathrm{~A}$ & 0.07 & $0.49 \mathrm{~A}$ & 0.33 & $0.08 \mathrm{~A}$ & 0.03 & $0.10 \mathrm{~A}$ & 0.04 & 0.09 & 0.962 \\
\hline & Fall & $0.06 \mathrm{~A}$ & 0.03 & $0.16 \mathrm{~A}$ & 0.15 & $0.00 \mathrm{~A}$ & 0.00 & $0.03 \mathrm{~A}$ & 0.02 & 1.09 & 0.369 \\
\hline & Winter & $0.11 \mathrm{AB}$ & 0.08 & $0.26 \mathrm{~A}$ & 0.17 & $0.01 \mathrm{~B}$ & 0.01 & $0.00 \mathrm{~B}$ & 0.00 & 3.69 & 0.024 \\
\hline & Total & $0.18 \mathrm{~A}$ & 0.07 & $0.29 \mathrm{AB}$ & 0.11 & $0.04 \mathrm{BC}$ & 0.01 & $0.05 \mathrm{C}$ & 0.01 & & \\
\hline Wood duck & Total & $0.47 \mathrm{~A}$ & 0.08 & $0.24 \mathrm{~B}$ & 0.05 & $0.08 \mathrm{C}$ & 0.04 & $0.11 \mathrm{C}$ & 0.07 & 12.28 & $<0.001$ \\
\hline
\end{tabular}

${ }^{a}$ Treatments encompassed the length of the associated island and one-half the width of the associated back channel.

b Spring: 21 March-7 April 2001, 23-25 March 2002; summer: 14-28 May, 11-27 June 2002, 16-25 May, 17-26 June, 17 July-13

August 2002; fall: 10-16 November 2001, 28 September-6 October 2002; winter: 26-28 January 2002.

${ }^{\mathrm{c}}$ Means in the same row followed by different letters are different $(P \leq 0.05)$. Means not followed by a letter indicate the test was not performed, due to interaction with season $(P \leq 0.05)$.

d Divers, grebes, cormorants, waterfowl, herons, coots, gulls and terns, sandpipers and associates, and belted kingfishers 
Appendix E. Continued.

${ }^{\mathrm{e}}$ Ducks and geese

${ }^{\mathrm{f}}$ Herons, sandpipers, and killdeer 
Appendix F. Frequency (no. birds/km), species richness (no. species/channel) and diversity (Shannon \& Weaver 1949) of all waterbirds, and frequency of waterfowl and wading birds encountered on back and main channels, including those occurring farther from the main channel shorelines than half the width of the associated back channel, averaged by channel across years, associated with 10 islands on the Ohio River, West Virginia, USA, 2001-2002.

\begin{tabular}{|c|c|c|c|c|c|c|c|c|}
\hline \multirow[b]{3}{*}{ Variable } & \multirow[b]{3}{*}{ Season $^{b}$} & \multirow[b]{3}{*}{ Measure } & \multicolumn{4}{|c|}{ Channel $^{\mathrm{a}}$} & \multirow[b]{3}{*}{$F_{1,27^{\mathrm{c}}}$} & \multirow[b]{3}{*}{$P$} \\
\hline & & & \multicolumn{2}{|c|}{ Back } & \multicolumn{2}{|c|}{ Main } & & \\
\hline & & & $\bar{x}$ & $\mathrm{SE}$ & $\bar{x}$ & $\mathrm{SE}$ & & \\
\hline \multirow[t]{3}{*}{ All waterbirds ${ }^{\mathrm{d}}$} & Total & Frequency & 6.66 & 0.74 & 5.70 & 0.80 & 3.35 & 0.078 \\
\hline & & Richness & 2.41 & 0.14 & 2.20 & 0.13 & 1.49 & 0.233 \\
\hline & & Diversity & 0.62 & 0.04 & 0.58 & 0.04 & 0.49 & 0.489 \\
\hline \multirow[t]{3}{*}{ Waterfowl $^{\mathrm{e}}$} & Spring & Frequency & 7.34 & 1.34 & 5.05 & 0.95 & 3.35 & 0.078 \\
\hline & Winter & Frequency & 5.45 & 1.98 & 2.27 & 1.37 & 3.31 & 0.080 \\
\hline & Total & Frequency & 5.52 & 0.71 & 4.09 & 0.76 & & \\
\hline Wading birds ${ }^{\mathrm{f}}$ & Total & Frequency & 0.74 & 0.10 & 0.70 & 0.12 & 1.06 & 0.312 \\
\hline
\end{tabular}

${ }^{a}$ Back channel: back channel-island side and back channel-mainland side treatments; main channel: main channel-island side and main channel-mainland side treatments. Treatments encompassed the length of the associated island and one-half the width of the associated back channel.

${ }^{b}$ Spring: 21 March-7 April 2001, 23-25 March 2002; fall: 10-16 November 2001, 28 September6 October 2002; winter: 26-28 January 2002.

${ }^{\mathrm{c}}$ No test indicates test was not performed, due to interaction with season $(P \leq 0.05)$.

d Divers, grebes, cormorants, waterfowl, herons, coots, gulls and terns, sandpipers and associates, and belted kingfishers

${ }^{\mathrm{e}}$ Ducks and geese

${ }^{\mathrm{f}}$ Herons, sandpipers, and killdeer 
Appendix G. Density (no. broods/ha) and frequency (no. broods/km) of wood duck broods encountered on island and mainland sides, averaged by side across years, associated with islands on the Ohio River, West Virginia, USA, 2001-2002.

\begin{tabular}{|c|c|c|c|c|c|c|}
\hline \multirow[b]{3}{*}{ Measure } & \multicolumn{4}{|c|}{$\mathrm{Side}^{\mathrm{a}}$} & \multirow[b]{3}{*}{$F_{1,27}$} & \multirow[b]{3}{*}{$P$} \\
\hline & \multicolumn{2}{|c|}{ Island } & \multicolumn{2}{|c|}{ Mainland } & & \\
\hline & $\bar{x}$ & SE & $\bar{x}$ & SE & & \\
\hline Density & 0.01 & 0.004 & 0.005 & 0.002 & 1.28 & 0.268 \\
\hline Frequency & 0.04 & 0.01 & 0.02 & 0.01 & 1.99 & 0.170 \\
\hline
\end{tabular}

${ }^{a}$ Island side: back channel-island side and main channel-island side treatments; mainland side: back channel-mainland side and main channel-mainland side treatments. Each treatment encompassed the length of the associated island and one-half the width of the associated back channel. 
Appendix H. Density (no. birds/ha) and frequency (no. birds $/ \mathrm{km}$ ) of all waterbird species encountered in 4 treatments $(\mathrm{BI}=$ back channel-island side, $\mathrm{BM}=$ back channel-mainland side, $\mathrm{MI}=$ main channel-island side, $\mathrm{MM}=$ main channel-mainland side), averaged by treatment across years, associated with 10 islands on the Ohio River, West Virginia, USA, 2001-2002.

\begin{tabular}{|c|c|c|c|c|c|c|c|c|c|c|c|}
\hline \multirow[b]{3}{*}{ Scientific name } & \multirow[b]{3}{*}{ Common name } & \multirow[b]{3}{*}{ Season ${ }^{\mathrm{b}}$} & \multirow[b]{3}{*}{ Measure } & \multicolumn{8}{|c|}{ Treatment $^{\mathrm{a}}$} \\
\hline & & & & \multicolumn{2}{|c|}{$\mathrm{BI}$} & \multicolumn{2}{|c|}{$\mathrm{BM}$} & \multicolumn{2}{|c|}{ MI } & \multicolumn{2}{|c|}{ MM } \\
\hline & & & & $\bar{x}$ & $\mathrm{SE}$ & $\bar{x}$ & $\mathrm{SE}$ & $\bar{x}$ & $\mathrm{SE}$ & $\bar{x}$ & $\mathrm{SE}$ \\
\hline \multirow[t]{10}{*}{ Actitis macularia } & Spotted sandpiper & Spring & Density & 0.0000 & 0.0000 & 0.0000 & 0.0000 & 0.0000 & 0.0000 & 0.0000 & 0.0000 \\
\hline & & & Frequency & 0.0000 & 0.0000 & 0.0000 & 0.0000 & 0.0000 & 0.0000 & 0.0000 & 0.0000 \\
\hline & & Summer & Density & 0.0251 & 0.0142 & 0.1382 & 0.0645 & 0.0602 & 0.0281 & 0.1070 & 0.0595 \\
\hline & & & Frequency & 0.1314 & 0.0590 & 0.4674 & 0.1644 & 0.2706 & 0.1007 & 0.4202 & 0.1440 \\
\hline & & Fall & Density & 0.0000 & 0.0000 & 0.0000 & 0.0000 & 0.0055 & 0.0055 & 0.0000 & 0.0000 \\
\hline & & & Frequency & 0.0000 & 0.0000 & 0.0000 & 0.0000 & 0.0284 & 0.0284 & 0.0000 & 0.0000 \\
\hline & & Winter & Density & 0.0068 & 0.0068 & 0.0000 & 0.0000 & 0.0000 & 0.0000 & 0.0000 & 0.0000 \\
\hline & & & Frequency & 0.0457 & 0.0457 & 0.0000 & 0.0000 & 0.0000 & 0.0000 & 0.0000 & 0.0000 \\
\hline & & Total & Density & 0.0082 & 0.0043 & 0.0395 & 0.0196 & 0.0188 & 0.0086 & 0.0306 & 0.0177 \\
\hline & & & Frequency & 0.0441 & 0.0190 & 0.1336 & 0.0526 & 0.0854 & 0.0326 & 0.1200 & 0.0464 \\
\hline \multirow[t]{10}{*}{ Aix sponsa } & Wood duck & Spring & Density & 0.6922 & 0.1993 & 0.1826 & 0.0827 & 0.0320 & 0.0185 & 0.0413 & 0.0231 \\
\hline & & & Frequency & 3.5561 & 1.1212 & 0.8392 & 0.3538 & 0.2044 & 0.1129 & 0.2500 & 0.1344 \\
\hline & & Summer & Density & 0.6208 & 0.1312 & 0.4174 & 0.0938 & 0.2314 & 0.1279 & 0.0871 & 0.0320 \\
\hline & & & Frequency & 3.0329 & 0.7238 & 1.9511 & 0.3650 & 1.0000 & 0.4048 & 0.6108 & 0.2844 \\
\hline & & Fall & Density & 0.3338 & 0.1503 & 0.2524 & 0.1181 & 0.0201 & 0.0154 & 0.2591 & 0.2430 \\
\hline & & & Frequency & 1.6248 & 0.7794 & 1.0825 & 0.4388 & 0.1706 & 0.1243 & 1.6380 & 1.5943 \\
\hline & & Winter & Density & 0.0000 & 0.0000 & 0.0000 & 0.0000 & 0.0000 & 0.0000 & 0.0000 & 0.0000 \\
\hline & & & Frequency & 0.0000 & 0.0000 & 0.0000 & 0.0000 & 0.0000 & 0.0000 & 0.0000 & 0.0000 \\
\hline & & Total & Density & 0.4705 & 0.0842 & 0.2436 & 0.0509 & 0.0810 & 0.0383 & 0.1107 & 0.0700 \\
\hline & & & Frequency & 2.3468 & 0.4577 & 1.1065 & 0.2031 & 0.3928 & 0.1316 & 0.7139 & 0.4618 \\
\hline \multirow[t]{2}{*}{ Anas americana } & American wigeon & Spring & Density & 0.0038 & 0.0038 & 0.0051 & 0.0051 & 0.0000 & 0.0000 & 0.0000 & 0.0000 \\
\hline & & & Frequency & 0.0466 & 0.0466 & 0.0607 & 0.0607 & 0.0000 & 0.0000 & 0.0000 & 0.0000 \\
\hline
\end{tabular}


Appendix H. Continued.

\begin{tabular}{|c|c|c|c|c|c|c|c|c|c|c|c|}
\hline \multirow[b]{3}{*}{ Scientific name } & \multirow[b]{3}{*}{ Common name } & \multirow[b]{3}{*}{ Season } & \multirow[b]{3}{*}{ Measure } & \multicolumn{8}{|c|}{ Treatment } \\
\hline & & & & \multicolumn{2}{|c|}{ BI } & \multicolumn{2}{|c|}{$\mathrm{BM}$} & \multicolumn{2}{|c|}{ MI } & \multicolumn{2}{|c|}{ MM } \\
\hline & & & & $\bar{x}$ & SE & $\bar{x}$ & SE & $\bar{x}$ & SE & $\bar{x}$ & SE \\
\hline & & Summer & Density & 0.0000 & 0.0000 & 0.0000 & 0.0000 & 0.0000 & 0.0000 & 0.0000 & 0.0000 \\
\hline & & & Frequency & 0.0000 & 0.0000 & 0.0000 & 0.0000 & 0.0000 & 0.0000 & 0.0000 & 0.0000 \\
\hline & & Fall & Density & 0.0000 & 0.0000 & 0.0000 & 0.0000 & 0.0000 & 0.0000 & 0.0000 & 0.0000 \\
\hline & & & Frequency & 0.0000 & 0.0000 & 0.0000 & 0.0000 & 0.0000 & 0.0000 & 0.0000 & 0.0000 \\
\hline & & Winter & Density & 0.0000 & 0.0000 & 0.0000 & 0.0000 & 0.0000 & 0.0000 & 0.0000 & 0.0000 \\
\hline & & & Frequency & 0.0000 & 0.0000 & 0.0000 & 0.0000 & 0.0000 & 0.0000 & 0.0000 & 0.0000 \\
\hline & & Total & Density & 0.0011 & 0.0011 & 0.0015 & 0.0015 & 0.0000 & 0.0000 & 0.0000 & 0.0000 \\
\hline & & & Frequency & 0.0133 & 0.0133 & 0.0173 & 0.0173 & 0.0000 & 0.0000 & 0.0000 & 0.0000 \\
\hline \multirow[t]{10}{*}{ Anas clypeata } & Northern shovelor & Spring & Density & 0.0265 & 0.0265 & 0.0000 & 0.0000 & 0.0110 & 0.0110 & 0.0000 & 0.0000 \\
\hline & & & Frequency & 0.1152 & 0.1152 & 0.0000 & 0.0000 & 0.0568 & 0.0568 & 0.0000 & 0.0000 \\
\hline & & Summer & Density & 0.0000 & 0.0000 & 0.0000 & 0.0000 & 0.0000 & 0.0000 & 0.0000 & 0.0000 \\
\hline & & & Frequency & 0.0000 & 0.0000 & 0.0000 & 0.0000 & 0.0000 & 0.0000 & 0.0000 & 0.0000 \\
\hline & & Fall & Density & 0.0000 & 0.0000 & 0.0000 & 0.0000 & 0.0000 & 0.0000 & 0.0000 & 0.0000 \\
\hline & & & Frequency & 0.0000 & 0.0000 & 0.0000 & 0.0000 & 0.0000 & 0.0000 & 0.0000 & 0.0000 \\
\hline & & Winter & Density & 0.0000 & 0.0000 & 0.0000 & 0.0000 & 0.0000 & 0.0000 & 0.0000 & 0.0000 \\
\hline & & & Frequency & 0.0000 & 0.0000 & 0.0000 & 0.0000 & 0.0000 & 0.0000 & 0.0000 & 0.0000 \\
\hline & & Total & Density & 0.0076 & 0.0076 & 0.0000 & 0.0000 & 0.0032 & 0.0032 & 0.0000 & 0.0000 \\
\hline & & & Frequency & 0.0329 & 0.0329 & 0.0000 & 0.0000 & 0.0162 & 0.0162 & 0.0000 & 0.0000 \\
\hline \multirow[t]{6}{*}{ Anas discors } & Blue-winged teal & Spring & Density & 0.0510 & 0.0282 & 0.0000 & 0.0000 & 0.0011 & 0.0011 & 0.0432 & 0.0362 \\
\hline & & & Frequency & 0.1900 & 0.1104 & 0.0000 & 0.0000 & 0.0114 & 0.0114 & 0.2846 & 0.2374 \\
\hline & & Summer & Density & 0.0000 & 0.0000 & 0.0000 & 0.0000 & 0.0000 & 0.0000 & 0.0000 & 0.0000 \\
\hline & & & Frequency & 0.0000 & 0.0000 & 0.0000 & 0.0000 & 0.0000 & 0.0000 & 0.0000 & 0.0000 \\
\hline & & Fall & Density & 0.0000 & 0.0000 & 0.0000 & 0.0000 & 0.0000 & 0.0000 & 0.0000 & 0.0000 \\
\hline & & & Frequency & 0.0000 & 0.0000 & 0.0000 & 0.0000 & 0.0000 & 0.0000 & 0.0000 & 0.0000 \\
\hline
\end{tabular}


Appendix H. Continued.

\begin{tabular}{|c|c|c|c|c|c|c|c|c|c|c|c|}
\hline \multirow[b]{3}{*}{ Scientific name } & \multirow[b]{3}{*}{ Common name } & \multirow[b]{3}{*}{ Season } & \multirow[b]{3}{*}{ Measure } & \multicolumn{8}{|c|}{ Treatment } \\
\hline & & & & \multicolumn{2}{|c|}{$\mathrm{BI}$} & \multicolumn{2}{|c|}{$\mathrm{BM}$} & \multicolumn{2}{|c|}{ MI } & \multicolumn{2}{|c|}{ MM } \\
\hline & & & & $\bar{x}$ & SE & $\bar{x}$ & SE & $\bar{x}$ & SE & $\bar{x}$ & SE \\
\hline & & Winter & Density & 0.0000 & 0.0000 & 0.0000 & 0.0000 & 0.0000 & 0.0000 & 0.0000 & 0.0000 \\
\hline & & & Frequency & 0.0000 & 0.0000 & 0.0000 & 0.0000 & 0.0000 & 0.0000 & 0.0000 & 0.0000 \\
\hline & & Total & Density & 0.0146 & 0.0084 & 0.0000 & 0.0000 & 0.0003 & 0.0003 & 0.0123 & 0.0104 \\
\hline & & & Frequency & 0.0543 & 0.0326 & 0.0000 & 0.0000 & 0.0033 & 0.0033 & 0.0813 & 0.0684 \\
\hline \multirow[t]{10}{*}{ Anas platyrhynchos } & Mallard & Spring & Density & 0.3764 & 0.2236 & 0.2425 & 0.1374 & 0.0515 & 0.0306 & 0.0546 & 0.0225 \\
\hline & & & Frequency & 1.4360 & 0.5656 & 0.5174 & 0.2416 & 0.2166 & 0.1244 & 0.2769 & 0.0988 \\
\hline & & Summer & Density & 0.1614 & 0.0684 & 0.4944 & 0.3262 & 0.0757 & 0.0317 & 0.1020 & 0.0399 \\
\hline & & & Frequency & 0.5167 & 0.2028 & 1.1792 & 0.6854 & 0.3071 & 0.0958 & 0.5134 & 0.1970 \\
\hline & & Fall & Density & 0.0555 & 0.0348 & 0.1606 & 0.1528 & 0.0000 & 0.0000 & 0.0346 & 0.0232 \\
\hline & & & Frequency & 0.3145 & 0.2281 & 0.3713 & 0.3233 & 0.0000 & 0.0000 & 0.1391 & 0.0858 \\
\hline & & Winter & Density & 0.1094 & 0.0759 & 0.2568 & 0.1739 & 0.0130 & 0.0130 & 0.0000 & 0.0000 \\
\hline & & & Frequency & 0.4332 & 0.2411 & 0.7568 & 0.3597 & 0.1370 & 0.1370 & 0.0000 & 0.0000 \\
\hline & & Total & Density & 0.1852 & 0.0688 & 0.2931 & 0.1118 & 0.0382 & 0.0130 & 0.0546 & 0.0150 \\
\hline & & & Frequency & 0.7097 & 0.1916 & 0.6989 & 0.2318 & 0.1692 & 0.0500 & 0.2654 & 0.0700 \\
\hline \multirow[t]{10}{*}{ Anas rubripes } & American black duck & Spring & Density & 0.0257 & 0.0177 & 0.0000 & 0.0000 & 0.0076 & 0.0066 & 0.0000 & 0.0000 \\
\hline & & & Frequency & 0.0846 & 0.0623 & 0.0000 & 0.0000 & 0.0258 & 0.0179 & 0.0000 & 0.0000 \\
\hline & & Summer & Density & 0.0000 & 0.0000 & 0.0000 & 0.0000 & 0.0000 & 0.0000 & 0.0000 & 0.0000 \\
\hline & & & Frequency & 0.0000 & 0.0000 & 0.0000 & 0.0000 & 0.0000 & 0.0000 & 0.0000 & 0.0000 \\
\hline & & Fall & Density & 0.0415 & 0.0415 & 0.0368 & 0.0368 & 0.0000 & 0.0000 & 0.0000 & 0.0000 \\
\hline & & & Frequency & 0.1168 & 0.1168 & 0.1186 & 0.1186 & 0.0000 & 0.0000 & 0.0000 & 0.0000 \\
\hline & & Winter & Density & 0.0000 & 0.0000 & 0.0000 & 0.0000 & 0.0043 & 0.0043 & 0.0000 & 0.0000 \\
\hline & & & Frequency & 0.0000 & 0.0000 & 0.0000 & 0.0000 & 0.0457 & 0.0457 & 0.0000 & 0.0000 \\
\hline & & Total & Density & 0.0192 & 0.0128 & 0.0105 & 0.0105 & 0.0028 & 0.0020 & 0.0000 & 0.0000 \\
\hline & & & Frequency & 0.0575 & 0.0376 & 0.0339 & 0.0339 & 0.0139 & 0.0083 & 0.0000 & 0.0000 \\
\hline
\end{tabular}


Appendix H. Continued.

\begin{tabular}{|c|c|c|c|c|c|c|c|c|c|c|c|}
\hline \multirow[b]{3}{*}{ Scientific name } & \multirow[b]{3}{*}{ Common name } & \multirow[b]{3}{*}{ Season } & \multirow[b]{3}{*}{ Measure } & \multicolumn{8}{|c|}{ Treatment } \\
\hline & & & & \multicolumn{2}{|c|}{$\mathrm{BI}$} & \multicolumn{2}{|c|}{$\mathrm{BM}$} & \multicolumn{2}{|c|}{ MI } & \multicolumn{2}{|c|}{$\mathrm{MM}$} \\
\hline & & & & $\bar{x}$ & SE & $\bar{x}$ & SE & $\bar{x}$ & SE & $\bar{x}$ & SE \\
\hline \multirow[t]{10}{*}{ Ardea herodias } & Great blue heron & Spring & Density & 0.1290 & 0.0558 & 0.0485 & 0.0343 & 0.0437 & 0.0194 & 0.0132 & 0.0066 \\
\hline & & & Frequency & 0.8045 & 0.3470 & 0.2950 & 0.2224 & 0.3079 & 0.1185 & 0.0888 & 0.0436 \\
\hline & & Summer & Density & 0.2050 & 0.0818 & 0.0930 & 0.0540 & 0.0980 & 0.0320 & 0.1046 & 0.0586 \\
\hline & & & Frequency & 0.7425 & 0.3178 & 0.2430 & 0.0840 & 0.4187 & 0.0971 & 0.3526 & 0.1094 \\
\hline & & Fall & Density & 0.1584 & 0.0311 & 0.0806 & 0.0543 & 0.1833 & 0.0673 & 0.0518 & 0.0234 \\
\hline & & & Frequency & 0.8084 & 0.1441 & 0.2632 & 0.1071 & 0.6745 & 0.1626 & 0.2954 & 0.1476 \\
\hline & & Winter & Density & 0.2325 & 0.0805 & 0.0399 & 0.0199 & 0.3100 & 0.0179 & 0.0720 & 0.0311 \\
\hline & & & Frequency & 1.6600 & 0.7225 & 0.2252 & 0.1080 & 0.1953 & 0.1060 & 0.3641 & 0.1151 \\
\hline & & Total & Density & 0.1739 & 0.0314 & 0.0692 & 0.0238 & 0.0973 & 0.0229 & 0.0587 & 0.0188 \\
\hline & & & Frequency & 0.9101 & 0.1736 & 0.2611 & 0.0747 & 0.4282 & 0.0675 & 0.2625 & 0.0569 \\
\hline \multirow[t]{10}{*}{ Aythya americana } & Redhead & Spring & Density & 0.0000 & 0.0000 & 0.0000 & 0.0000 & 0.0000 & 0.0000 & 0.0164 & 0.0164 \\
\hline & & & Frequency & 0.0000 & 0.0000 & 0.0000 & 0.0000 & 0.0000 & 0.0000 & 0.1663 & 0.1663 \\
\hline & & Summer & Density & 0.0000 & 0.0000 & 0.0000 & 0.0000 & 0.0000 & 0.0000 & 0.0000 & 0.0000 \\
\hline & & & Frequency & 0.0000 & 0.0000 & 0.0000 & 0.0000 & 0.0000 & 0.0000 & 0.0000 & 0.0000 \\
\hline & & Fall & Density & 0.0000 & 0.0000 & 0.0000 & 0.0000 & 0.0000 & 0.0000 & 0.0000 & 0.0000 \\
\hline & & & Frequency & 0.0000 & 0.0000 & 0.0000 & 0.0000 & 0.0000 & 0.0000 & 0.0000 & 0.0000 \\
\hline & & Winter & Density & 0.0000 & 0.0000 & 0.0000 & 0.0000 & 0.0000 & 0.0000 & 0.0000 & 0.0000 \\
\hline & & & Frequency & 0.0000 & 0.0000 & 0.0000 & 0.0000 & 0.0000 & 0.0000 & 0.0000 & 0.0000 \\
\hline & & Total & Density & 0.0000 & 0.0000 & 0.0000 & 0.0000 & 0.0000 & 0.0000 & 0.0047 & 0.0047 \\
\hline & & & Frequency & 0.0000 & 0.0000 & 0.0000 & 0.0000 & 0.0000 & 0.0000 & 0.0475 & 0.0475 \\
\hline \multirow[t]{3}{*}{ Aythya collaris } & Ring-necked duck & Spring & Density & 0.0000 & 0.0000 & 0.0000 & 0.0000 & 0.0000 & 0.0000 & 0.0000 & 0.0000 \\
\hline & & & Frequency & 0.0000 & 0.0000 & 0.0000 & 0.0000 & 0.0000 & 0.0000 & 0.0000 & 0.0000 \\
\hline & & Summer & Density & 0.0000 & 0.0000 & 0.0000 & 0.0000 & 0.0000 & 0.0000 & 0.0000 & 0.0000 \\
\hline
\end{tabular}


Appendix H. Continued.

\begin{tabular}{|c|c|c|c|c|c|c|c|c|c|c|c|}
\hline \multirow[b]{3}{*}{ Scientific name } & \multirow[b]{3}{*}{ Common name } & \multirow[b]{3}{*}{ Season } & \multirow[b]{3}{*}{ Measure } & \multicolumn{8}{|c|}{ Treatment } \\
\hline & & & & \multicolumn{2}{|c|}{ BI } & \multicolumn{2}{|c|}{$\mathrm{BM}$} & \multicolumn{2}{|c|}{ MI } & \multicolumn{2}{|c|}{ MM } \\
\hline & & & & $x$ & $\mathrm{SE}$ & $x$ & $\mathrm{SE}$ & $x$ & SE & $x$ & SE \\
\hline & & & Frequency & 0.0000 & 0.0000 & 0.0000 & 0.0000 & 0.0000 & 0.0000 & 0.0000 & 0.0000 \\
\hline & & Fall & Density & 0.0000 & 0.0000 & 0.0000 & 0.0000 & 0.0000 & 0.0000 & 0.0000 & 0.0000 \\
\hline & & & Frequency & 0.0000 & 0.0000 & 0.0000 & 0.0000 & 0.0000 & 0.0000 & 0.0000 & 0.0000 \\
\hline & & Winter & Density & 0.0068 & 0.0068 & 0.0000 & 0.0000 & 0.0000 & 0.0000 & 0.0000 & 0.0000 \\
\hline & & & Frequency & 0.0457 & 0.0457 & 0.0000 & 0.0000 & 0.0000 & 0.0000 & 0.0000 & 0.0000 \\
\hline & & Total & Density & 0.0010 & 0.0010 & 0.0000 & 0.0000 & 0.0000 & 0.0000 & 0.0000 & 0.0000 \\
\hline & & & Frequency & 0.0065 & 0.0065 & 0.0000 & 0.0000 & 0.0000 & 0.0000 & 0.0000 & 0.0000 \\
\hline \multirow[t]{10}{*}{ Aythya spp. } & Scaup spp. & Spring & Density & 0.1000 & 0.0662 & 0.0410 & 0.0323 & 0.0163 & 0.0106 & 0.1096 & 0.1096 \\
\hline & & & Frequency & 0.8200 & 0.5172 & 0.4230 & 0.3783 & 0.1171 & 0.0917 & 0.3152 & 0.3152 \\
\hline & & Summer & Density & 0.0000 & 0.0000 & 0.0000 & 0.0000 & 0.0000 & 0.0000 & 0.0000 & 0.0000 \\
\hline & & & Frequency & 0.0000 & 0.0000 & 0.0000 & 0.0000 & 0.0000 & 0.0000 & 0.0000 & 0.0000 \\
\hline & & Fall & Density & 0.0150 & 0.0150 & 0.0000 & 0.0000 & 0.0000 & 0.0000 & 0.0000 & 0.0000 \\
\hline & & & Frequency & 0.0915 & 0.0915 & 0.0000 & 0.0000 & 0.0000 & 0.0000 & 0.0000 & 0.0000 \\
\hline & & Winter & Density & 0.0000 & 0.0000 & 0.0000 & 0.0000 & 0.0043 & 0.0043 & 0.0147 & 0.0147 \\
\hline & & & Frequency & 0.0000 & 0.0000 & 0.0000 & 0.0000 & 0.0457 & 0.0457 & 0.0997 & 0.0997 \\
\hline & & Total & Density & 0.0328 & 0.0197 & 0.0117 & 0.0093 & 0.0053 & 0.0031 & 0.0334 & 0.0314 \\
\hline & & & Frequency & 0.2604 & 0.1534 & 0.1209 & 0.1086 & 0.0400 & 0.0272 & 0.1043 & 0.0910 \\
\hline \multirow[t]{7}{*}{ Branta canadensis } & Canada goose & Spring & Density & 0.5994 & 0.1706 & 0.6346 & 0.2320 & 0.8165 & 0.1813 & 0.3126 & 0.0958 \\
\hline & & & Frequency & 3.6020 & 1.0705 & 2.0456 & 0.5334 & 3.9927 & 0.7762 & 1.7853 & 0.5017 \\
\hline & & Summer & Density & 0.2315 & 0.1128 & 1.4195 & 0.6044 & 1.1139 & 0.8072 & 1.9091 & 0.9414 \\
\hline & & & Frequency & 1.3626 & 0.7626 & 6.1726 & 2.8782 & 4.0431 & 2.3120 & 7.1202 & 3.4000 \\
\hline & & Fall & Density & 0.0154 & 0.0154 & 0.0543 & 0.0543 & 0.0499 & 0.0442 & 0.1242 & 0.1242 \\
\hline & & & Frequency & 0.1866 & 0.1866 & 0.0792 & 0.0792 & 0.2921 & 0.2330 & 0.3340 & 0.3340 \\
\hline & & Winter & Density & 0.6267 & 0.4371 & 1.5745 & 0.8545 & 0.3554 & 0.2210 & 0.2799 & 0.2735 \\
\hline
\end{tabular}


Appendix H. Continued.

\begin{tabular}{|c|c|c|c|c|c|c|c|c|c|c|c|}
\hline \multirow[b]{3}{*}{ Scientific name } & \multirow[b]{3}{*}{ Common name } & \multirow[b]{3}{*}{ Season } & \multirow[b]{3}{*}{ Measure } & \multicolumn{8}{|c|}{ Treatment } \\
\hline & & & & \multicolumn{2}{|c|}{$\mathrm{BI}$} & \multicolumn{2}{|c|}{$\mathrm{BM}$} & \multicolumn{2}{|c|}{ MI } & \multicolumn{2}{|c|}{ MM } \\
\hline & & & & $x$ & SE & $x$ & SE & $x$ & SE & $x$ & SE \\
\hline & & & Frequency & 4.1607 & 2.6564 & 5.5042 & 2.9472 & 1.2692 & 0.5349 & 2.8388 & 2.7656 \\
\hline & & Total & Density & 0.3313 & 0.0883 & 0.8273 & 0.2281 & 0.6166 & 0.2400 & 0.7102 & 0.2854 \\
\hline & & & Frequency & 2.0660 & 0.5529 & 3.1570 & 0.9643 & 2.5607 & 0.7209 & 3.0454 & 1.0892 \\
\hline \multirow[t]{10}{*}{ Bucephala albeola } & Bufflehead & Spring & Density & 0.0849 & 0.0822 & 0.0000 & 0.0000 & 0.0218 & 0.0153 & 0.0142 & 0.0142 \\
\hline & & & Frequency & 0.5343 & 0.5025 & 0.0000 & 0.0000 & 0.1200 & 0.0943 & 0.0520 & 0.0520 \\
\hline & & Summer & Density & 0.0000 & 0.0000 & 0.0000 & 0.0000 & 0.0000 & 0.0000 & 0.0000 & 0.0000 \\
\hline & & & Frequency & 0.0000 & 0.0000 & 0.0000 & 0.0000 & 0.0000 & 0.0000 & 0.0000 & 0.0000 \\
\hline & & Fall & Density & 0.0000 & 0.0000 & 0.0000 & 0.0000 & 0.0000 & 0.0000 & 0.0033 & 0.0033 \\
\hline & & & Frequency & 0.0000 & 0.0000 & 0.0000 & 0.0000 & 0.0000 & 0.0000 & 0.0333 & 0.0333 \\
\hline & & Winter & Density & 0.0000 & 0.0000 & 0.0000 & 0.0000 & 0.0131 & 0.0131 & 0.0000 & 0.0000 \\
\hline & & & Frequency & 0.0000 & 0.0000 & 0.0000 & 0.0000 & 0.0287 & 0.0287 & 0.0000 & 0.0000 \\
\hline & & Total & Density & 0.0242 & 0.0235 & 0.0000 & 0.0000 & 0.0081 & 0.0048 & 0.0050 & 0.0042 \\
\hline & & & Frequency & 0.1526 & 0.1439 & 0.0000 & 0.0000 & 0.0384 & 0.0275 & 0.0244 & 0.0175 \\
\hline \multirow[t]{10}{*}{ Butorides virescens } & Green heron & Spring & Density & 0.0000 & 0.0000 & 0.0000 & 0.0000 & 0.0000 & 0.0000 & 0.0000 & 0.0000 \\
\hline & & & Frequency & 0.0000 & 0.0000 & 0.0000 & 0.0000 & 0.0000 & 0.0000 & 0.0000 & 0.0000 \\
\hline & & Summer & Density & 0.0135 & 0.0093 & 0.0383 & 0.0154 & 0.0076 & 0.0066 & 0.0037 & 0.0037 \\
\hline & & & Frequency & 0.0745 & 0.0528 & 0.1698 & 0.0637 & 0.0258 & 0.0179 & 0.0249 & 0.0249 \\
\hline & & Fall & Density & 0.0583 & 0.0521 & 0.0000 & 0.0000 & 0.0131 & 0.0131 & 0.1190 & 0.1190 \\
\hline & & & Frequency & 0.0928 & 0.0798 & 0.0000 & 0.0000 & 0.0287 & 0.0287 & 0.1972 & 0.1972 \\
\hline & & Winter & Density & 0.0000 & 0.0000 & 0.0000 & 0.0000 & 0.0000 & 0.0000 & 0.0000 & 0.0000 \\
\hline & & & Frequency & 0.0000 & 0.0000 & 0.0000 & 0.0000 & 0.0000 & 0.0000 & 0.0000 & 0.0000 \\
\hline & & Total & Density & 0.0205 & 0.0151 & 0.0109 & 0.0048 & 0.0059 & 0.0042 & 0.0351 & 0.0340 \\
\hline & & & Frequency & 0.0478 & 0.0273 & 0.0485 & 0.0201 & 0.0156 & 0.0096 & 0.0635 & 0.0567 \\
\hline
\end{tabular}


Appendix H. Continued.

\begin{tabular}{|c|c|c|c|c|c|c|c|c|c|c|c|}
\hline \multirow[b]{3}{*}{ Scientific name } & \multirow[b]{3}{*}{ Common name } & \multirow[b]{3}{*}{ Season } & \multirow[b]{3}{*}{ Measure } & \multicolumn{8}{|c|}{ Treatment } \\
\hline & & & & \multicolumn{2}{|c|}{$\mathrm{BI}$} & \multicolumn{2}{|c|}{$\mathrm{BM}$} & \multicolumn{2}{|c|}{ MI } & \multicolumn{2}{|c|}{ MM } \\
\hline & & & & $\bar{x}$ & $\mathrm{SE}$ & $\bar{x}$ & $\mathrm{SE}$ & $\bar{x}$ & SE & $\bar{x}$ & $\mathrm{SE}$ \\
\hline \multirow[t]{10}{*}{ Ceryle alcyon } & Belted kingfisher & Spring & Density & 0.0312 & 0.0182 & 0.0205 & 0.0104 & 0.0157 & 0.0114 & 0.1589 & 0.1182 \\
\hline & & & Frequency & 0.1521 & 0.0811 & 0.1159 & 0.0472 & 0.0936 & 0.0612 & 0.3882 & 0.2027 \\
\hline & & Summer & Density & 0.0559 & 0.0272 & 0.1319 & 0.0579 & 0.1975 & 0.0635 & 0.4790 & 0.2073 \\
\hline & & & Frequency & 0.2177 & 0.0971 & 0.4758 & 0.1363 & 0.6915 & 0.1290 & 1.2134 & 0.3544 \\
\hline & & Fall & Density & 0.0951 & 0.0355 & 0.1735 & 0.1079 & 0.1583 & 0.0611 & 0.1894 & 0.0647 \\
\hline & & & Frequency & 0.4270 & 0.1342 & 0.4386 & 0.1680 & 0.5397 & 0.1403 & 0.6654 & 0.1542 \\
\hline & & Winter & Density & 0.1324 & 0.1027 & 0.0229 & 0.0163 & 0.1145 & 0.1122 & 0.1565 & 0.1163 \\
\hline & & & Frequency & 0.3078 & 0.1745 & 0.1062 & 0.0711 & 0.1791 & 0.1554 & 0.4272 & 0.2012 \\
\hline & & Total & Density & 0.0710 & 0.0199 & 0.0964 & 0.0355 & 0.1225 & 0.0305 & 0.2588 & 0.0731 \\
\hline & & & Frequency & 0.2716 & 0.0584 & 0.3095 & 0.0661 & 0.4041 & 0.0673 & 0.7088 & 0.1319 \\
\hline \multirow[t]{10}{*}{ Charadrius vociferus } & Killdeer & Spring & Density & 0.0034 & 0.0034 & 0.0000 & 0.0000 & 0.0000 & 0.0000 & 0.0071 & 0.0071 \\
\hline & & & Frequency & 0.0229 & 0.0229 & 0.0000 & 0.0000 & 0.0000 & 0.0000 & 0.0260 & 0.0260 \\
\hline & & Summer & Density & 0.0000 & 0.0000 & 0.0440 & 0.0325 & 0.0095 & 0.0070 & 0.0569 & 0.0499 \\
\hline & & & Frequency & 0.0000 & 0.0000 & 0.1374 & 0.0812 & 0.0370 & 0.0262 & 0.2079 & 0.1824 \\
\hline & & Fall & Density & 0.0000 & 0.0000 & 0.0000 & 0.0000 & 0.0118 & 0.0118 & 0.3531 & 0.2989 \\
\hline & & & Frequency & 0.0000 & 0.0000 & 0.0000 & 0.0000 & 0.0908 & 0.0908 & 0.7200 & 0.5154 \\
\hline & & Winter & Density & 0.0000 & 0.0000 & 0.0000 & 0.0000 & 0.0000 & 0.0000 & 0.0000 & 0.0000 \\
\hline & & & Frequency & 0.0000 & 0.0000 & 0.0000 & 0.0000 & 0.0000 & 0.0000 & 0.0000 & 0.0000 \\
\hline & & Total & Density & 0.0010 & 0.0010 & 0.0126 & 0.0094 & 0.0061 & 0.0039 & 0.1192 & 0.0869 \\
\hline & & & Frequency & 0.0065 & 0.0065 & 0.0393 & 0.0240 & 0.0365 & 0.0269 & 0.2725 & 0.1575 \\
\hline \multirow[t]{4}{*}{ Fulica americana } & American coot & Spring & Density & 0.0093 & 0.0093 & 0.0000 & 0.0000 & 0.0150 & 0.0103 & 0.0000 & 0.0000 \\
\hline & & & Frequency & 0.0290 & 0.0290 & 0.0000 & 0.0000 & 0.0788 & 0.0566 & 0.0000 & 0.0000 \\
\hline & & Summer & Density & 0.0000 & 0.0000 & 0.0000 & 0.0000 & 0.0000 & 0.0000 & 0.0000 & 0.0000 \\
\hline & & & Frequency & 0.0000 & 0.0000 & 0.0000 & 0.0000 & 0.0000 & 0.0000 & 0.0000 & 0.0000 \\
\hline
\end{tabular}


Appendix H. Continued.

\begin{tabular}{|c|c|c|c|c|c|c|c|c|c|c|c|}
\hline \multirow[b]{3}{*}{ Scientific name } & \multirow[b]{3}{*}{ Common name } & \multirow[b]{3}{*}{ Season } & \multirow[b]{3}{*}{ Measure } & \multicolumn{8}{|c|}{ Treatment } \\
\hline & & & & \multicolumn{2}{|c|}{$\mathrm{BI}$} & \multicolumn{2}{|c|}{$\mathrm{BM}$} & \multicolumn{2}{|c|}{ MI } & \multicolumn{2}{|c|}{ MM } \\
\hline & & & & $\bar{x}$ & SE & $\bar{x}$ & SE & $\bar{x}$ & SE & $\bar{x}$ & SE \\
\hline & & Fall & Density & 0.0000 & 0.0000 & 0.0000 & 0.0000 & 0.0000 & 0.0000 & 0.0000 & 0.0000 \\
\hline & & & Frequency & 0.0000 & 0.0000 & 0.0000 & 0.0000 & 0.0000 & 0.0000 & 0.0000 & 0.0000 \\
\hline & & Winter & Density & 0.0000 & 0.0000 & 0.0000 & 0.0000 & 0.0000 & 0.0000 & 0.0000 & 0.0000 \\
\hline & & & Frequency & 0.0000 & 0.0000 & 0.0000 & 0.0000 & 0.0000 & 0.0000 & 0.0000 & 0.0000 \\
\hline & & Total & Density & 0.0026 & 0.0026 & 0.0000 & 0.0000 & 0.0043 & 0.0030 & 0.0000 & 0.0000 \\
\hline & & & Frequency & 0.0083 & 0.0083 & 0.0000 & 0.0000 & 0.0225 & 0.0164 & 0.0000 & 0.0000 \\
\hline \multirow[t]{10}{*}{ Gavia immer } & Common loon & Spring & Density & 0.0000 & 0.0000 & 0.0000 & 0.0000 & 0.0000 & 0.0000 & 0.0000 & 0.0000 \\
\hline & & & Frequency & 0.0000 & 0.0000 & 0.0000 & 0.0000 & 0.0000 & 0.0000 & 0.0000 & 0.0000 \\
\hline & & Summer & Density & 0.0000 & 0.0000 & 0.0000 & 0.0000 & 0.0000 & 0.0000 & 0.0000 & 0.0000 \\
\hline & & & Frequency & 0.0000 & 0.0000 & 0.0000 & 0.0000 & 0.0000 & 0.0000 & 0.0000 & 0.0000 \\
\hline & & Fall & Density & 0.0000 & 0.0000 & 0.0026 & 0.0026 & 0.0000 & 0.0000 & 0.0000 & 0.0000 \\
\hline & & & Frequency & 0.0000 & 0.0000 & 0.0303 & 0.0303 & 0.0000 & 0.0000 & 0.0000 & 0.0000 \\
\hline & & Winter & Density & 0.0000 & 0.0000 & 0.0000 & 0.0000 & 0.0000 & 0.0000 & 0.0000 & 0.0000 \\
\hline & & & Frequency & 0.0000 & 0.0000 & 0.0000 & 0.0000 & 0.0000 & 0.0000 & 0.0000 & 0.0000 \\
\hline & & Total & Density & 0.0000 & 0.0000 & 0.0007 & 0.0007 & 0.0000 & 0.0000 & 0.0000 & 0.0000 \\
\hline & & & Frequency & 0.0000 & 0.0000 & 0.0087 & 0.0087 & 0.0000 & 0.0000 & 0.0000 & 0.0000 \\
\hline \multirow[t]{8}{*}{ Larus delawarensis } & Ring-billed gull & Spring & Density & 0.0000 & 0.0000 & 0.0000 & 0.0000 & 0.0324 & 0.0294 & 0.0482 & 0.0313 \\
\hline & & & Frequency & 0.0000 & 0.0000 & 0.0000 & 0.0000 & 0.2496 & 0.2269 & 0.3526 & 0.2410 \\
\hline & & Summer & Density & 0.0000 & 0.0000 & 0.0000 & 0.0000 & 0.0000 & 0.0000 & 0.0000 & 0.0000 \\
\hline & & & Frequency & 0.0000 & 0.0000 & 0.0000 & 0.0000 & 0.0000 & 0.0000 & 0.0000 & 0.0000 \\
\hline & & Fall & Density & 0.0000 & 0.0000 & 0.0000 & 0.0000 & 0.0000 & 0.0000 & 0.0000 & 0.0000 \\
\hline & & & Frequency & 0.0000 & 0.0000 & 0.0000 & 0.0000 & 0.0000 & 0.0000 & 0.0000 & 0.0000 \\
\hline & & Winter & Density & 0.0000 & 0.0000 & 0.0000 & 0.0000 & 0.0000 & 0.0000 & 0.0147 & 0.0147 \\
\hline & & & Frequency & 0.0000 & 0.0000 & 0.0000 & 0.0000 & 0.0000 & 0.0000 & 0.0997 & 0.0997 \\
\hline
\end{tabular}


Appendix H. Continued.

\begin{tabular}{|c|c|c|c|c|c|c|c|c|c|c|c|}
\hline \multirow[b]{3}{*}{ Scientific name } & \multirow[b]{3}{*}{ Common name } & \multirow[b]{3}{*}{ Season } & \multirow[b]{3}{*}{ Measure } & \multicolumn{8}{|c|}{ Treatment } \\
\hline & & & & \multicolumn{2}{|c|}{$\mathrm{BI}$} & \multicolumn{2}{|c|}{$\mathrm{BM}$} & \multicolumn{2}{|c|}{ MI } & \multicolumn{2}{|c|}{ MM } \\
\hline & & & & $\bar{x}$ & SE & $\bar{x}$ & SE & $\bar{x}$ & SE & $\bar{x}$ & SE \\
\hline & & Total & Density & 0.0000 & 0.0000 & 0.0000 & 0.0000 & 0.0092 & 0.0084 & 0.0159 & 0.0094 \\
\hline & & & Frequency & 0.0000 & 0.0000 & 0.0000 & 0.0000 & 0.0713 & 0.0651 & 0.1150 & 0.0714 \\
\hline \multirow[t]{10}{*}{ Lophodytes cucullatus } & Hooded merganser & Spring & Density & 0.0114 & 0.0069 & 0.0378 & 0.0287 & 0.0059 & 0.0059 & 0.0000 & 0.0000 \\
\hline & & & Frequency & 0.0686 & 0.0396 & 0.1627 & 0.0985 & 0.0454 & 0.0454 & 0.0000 & 0.0000 \\
\hline & & Summer & Density & 0.0000 & 0.0000 & 0.0000 & 0.0000 & 0.0000 & 0.0000 & 0.0014 & 0.0014 \\
\hline & & & Frequency & 0.0000 & 0.0000 & 0.0000 & 0.0000 & 0.0000 & 0.0000 & 0.0166 & 0.0166 \\
\hline & & Fall & Density & 0.0000 & 0.0000 & 0.0090 & 0.0090 & 0.0000 & 0.0000 & 0.0000 & 0.0000 \\
\hline & & & Frequency & 0.0000 & 0.0000 & 0.1062 & 0.1062 & 0.0000 & 0.0000 & 0.0000 & 0.0000 \\
\hline & & Winter & Density & 0.0000 & 0.0000 & 0.0000 & 0.0000 & 0.0000 & 0.0000 & 0.0000 & 0.0000 \\
\hline & & & Frequency & 0.0000 & 0.0000 & 0.0000 & 0.0000 & 0.0000 & 0.0000 & 0.0000 & 0.0000 \\
\hline & & Total & Density & 0.0032 & 0.0020 & 0.0134 & 0.0086 & 0.0017 & 0.0017 & 0.0004 & 0.0004 \\
\hline & & & Frequency & 0.0196 & 0.0117 & 0.0768 & 0.0415 & 0.0130 & 0.0130 & 0.0048 & 0.0048 \\
\hline \multirow[t]{10}{*}{ Mergus serrator } & Red-breasted merganser & Spring & Density & 0.0000 & 0.0000 & 0.0000 & 0.0000 & 0.0469 & 0.0469 & 0.0000 & 0.0000 \\
\hline & & & Frequency & 0.0000 & 0.0000 & 0.0000 & 0.0000 & 0.2786 & 0.2786 & 0.0000 & 0.0000 \\
\hline & & Summer & Density & 0.0000 & 0.0000 & 0.0000 & 0.0000 & 0.0000 & 0.0000 & 0.0000 & 0.0000 \\
\hline & & & Frequency & 0.0000 & 0.0000 & 0.0000 & 0.0000 & 0.0000 & 0.0000 & 0.0000 & 0.0000 \\
\hline & & Fall & Density & 0.0187 & 0.0187 & 0.0064 & 0.0064 & 0.0000 & 0.0000 & 0.0000 & 0.0000 \\
\hline & & & Frequency & 0.0404 & 0.0404 & 0.0134 & 0.0134 & 0.0000 & 0.0000 & 0.0000 & 0.0000 \\
\hline & & Winter & Density & 0.0000 & 0.0000 & 0.0000 & 0.0000 & 0.0000 & 0.0000 & 0.0000 & 0.0000 \\
\hline & & & Frequency & 0.0000 & 0.0000 & 0.0000 & 0.0000 & 0.0000 & 0.0000 & 0.0000 & 0.0000 \\
\hline & & Total & Density & 0.0054 & 0.0054 & 0.0018 & 0.0018 & 0.0134 & 0.0134 & 0.0000 & 0.0000 \\
\hline & & & Frequency & 0.0116 & 0.0116 & 0.0038 & 0.0038 & 0.0796 & 0.0796 & 0.0000 & 0.0000 \\
\hline Phalacrocorax auritus & Double-crested cormorant & Spring & Density & 0.0086 & 0.0060 & 0.0000 & 0.0000 & 0.0679 & 0.0568 & 0.0967 & 0.0855 \\
\hline
\end{tabular}


Appendix H. Continued.

\begin{tabular}{|c|c|c|c|c|c|c|c|c|c|c|c|}
\hline \multirow[b]{3}{*}{ Scientific name } & \multirow[b]{3}{*}{ Common name } & \multirow[b]{3}{*}{ Season } & \multirow[b]{3}{*}{ Measure } & \multicolumn{8}{|c|}{ Treatment } \\
\hline & & & & \multicolumn{2}{|c|}{$\mathrm{BI}$} & \multicolumn{2}{|c|}{$\mathrm{BM}$} & \multicolumn{2}{|c|}{ MI } & \multicolumn{2}{|c|}{ MM } \\
\hline & & & & $\bar{x}$ & $\mathrm{SE}$ & $\bar{x}$ & SE & $\bar{x}$ & SE & $\bar{x}$ & $\mathrm{SE}$ \\
\hline & & & Frequency & 0.0851 & 0.0651 & 0.0000 & 0.0000 & 0.1689 & 0.1166 & 0.4019 & 0.3200 \\
\hline & & Summer & Density & 0.0026 & 0.0018 & 0.0083 & 0.0070 & 0.0076 & 0.0066 & 0.0086 & 0.0072 \\
\hline & & & Frequency & 0.0311 & 0.0214 & 0.0605 & 0.0471 & 0.0258 & 0.0179 & 0.0636 & 0.0490 \\
\hline & & Fall & Density & 0.0066 & 0.0066 & 0.0000 & 0.0000 & 0.0225 & 0.0214 & 0.0000 & 0.0000 \\
\hline & & & Frequency & 0.0288 & 0.0288 & 0.0000 & 0.0000 & 0.0728 & 0.0619 & 0.0000 & 0.0000 \\
\hline & & Winter & Density & 0.0000 & 0.0000 & 0.0000 & 0.0000 & 0.0000 & 0.0000 & 0.0000 & 0.0000 \\
\hline & & & Frequency & 0.0000 & 0.0000 & 0.0000 & 0.0000 & 0.0000 & 0.0000 & 0.0000 & 0.0000 \\
\hline & & Total & Density & 0.0051 & 0.0026 & 0.0024 & 0.0020 & 0.0280 & 0.0174 & 0.0301 & 0.0246 \\
\hline & & & Frequency & 0.0414 & 0.0212 & 0.0173 & 0.0136 & 0.0764 & 0.0381 & 0.1330 & 0.0931 \\
\hline \multirow[t]{10}{*}{ Podiceps auritus } & Horned grebe & Spring & Density & 0.0000 & 0.0000 & 0.0076 & 0.0064 & 0.0000 & 0.0000 & 0.0000 & 0.0000 \\
\hline & & & Frequency & 0.0000 & 0.0000 & 0.0286 & 0.0197 & 0.0000 & 0.0000 & 0.0000 & 0.0000 \\
\hline & & Summer & Density & 0.0000 & 0.0000 & 0.0000 & 0.0000 & 0.0000 & 0.0000 & 0.0000 & 0.0000 \\
\hline & & & Frequency & 0.0000 & 0.0000 & 0.0000 & 0.0000 & 0.0000 & 0.0000 & 0.0000 & 0.0000 \\
\hline & & Fall & Density & 0.0000 & 0.0000 & 0.0000 & 0.0000 & 0.0000 & 0.0000 & 0.0000 & 0.0000 \\
\hline & & & Frequency & 0.0000 & 0.0000 & 0.0000 & 0.0000 & 0.0000 & 0.0000 & 0.0000 & 0.0000 \\
\hline & & Winter & Density & 0.0000 & 0.0000 & 0.0000 & 0.0000 & 0.0000 & 0.0000 & 0.0000 & 0.0000 \\
\hline & & & Frequency & 0.0000 & 0.0000 & 0.0000 & 0.0000 & 0.0000 & 0.0000 & 0.0000 & 0.0000 \\
\hline & & Total & Density & 0.0000 & 0.0000 & 0.0022 & 0.0018 & 0.0000 & 0.0000 & 0.0000 & 0.0000 \\
\hline & & & Frequency & 0.0000 & 0.0000 & 0.0082 & 0.0057 & 0.0000 & 0.0000 & 0.0000 & 0.0000 \\
\hline \multirow[t]{5}{*}{ Podilymbus podiceps } & Pied-billed grebe & Spring & Density & 0.0221 & 0.0138 & 0.0286 & 0.0195 & 0.0070 & 0.0056 & 0.0125 & 0.0088 \\
\hline & & & Frequency & 0.0633 & 0.0360 & 0.1182 & 0.0692 & 0.0446 & 0.0320 & 0.0638 & 0.0510 \\
\hline & & Summer & Density & 0.0000 & 0.0000 & 0.0000 & 0.0000 & 0.0214 & 0.0214 & 0.0000 & 0.0000 \\
\hline & & & Frequency & 0.0000 & 0.0000 & 0.0000 & 0.0000 & 0.0614 & 0.0614 & 0.0000 & 0.0000 \\
\hline & & Fall & Density & 0.0000 & 0.0000 & 0.0077 & 0.0077 & 0.0000 & 0.0000 & 0.0000 & 0.0000 \\
\hline
\end{tabular}


Appendix H. Continued.

\begin{tabular}{|c|c|c|c|c|c|c|c|c|c|c|c|}
\hline \multirow[b]{3}{*}{ Scientific name } & \multirow[b]{3}{*}{ Common name } & \multirow[b]{3}{*}{ Season } & \multirow[b]{3}{*}{ Measure } & \multicolumn{8}{|c|}{ Treatment } \\
\hline & & & & \multicolumn{2}{|c|}{$\mathrm{BI}$} & \multicolumn{2}{|c|}{$\mathrm{BM}$} & \multicolumn{2}{|c|}{ MI } & \multicolumn{2}{|c|}{ MM } \\
\hline & & & & $\bar{x}$ & SE & $\bar{x}$ & $\mathrm{SE}$ & $\bar{x}$ & SE & $\bar{x}$ & $\mathrm{SE}$ \\
\hline & & & Frequency & 0.0000 & 0.0000 & 0.0286 & 0.0286 & 0.0000 & 0.0000 & 0.0000 & 0.0000 \\
\hline & & Winter & Density & 0.0000 & 0.0000 & 0.2249 & 0.2167 & 0.0000 & 0.0000 & 0.0142 & 0.0142 \\
\hline & & & Frequency & 0.0000 & 0.0000 & 0.3661 & 0.3153 & 0.0000 & 0.0000 & 0.0520 & 0.0520 \\
\hline & & Total & Density & 0.0063 & 0.0041 & 0.0425 & 0.0315 & 0.0081 & 0.0063 & 0.0056 & 0.0032 \\
\hline & & & Frequency & 0.0181 & 0.0107 & 0.0942 & 0.0500 & 0.0303 & 0.0197 & 0.0256 & 0.0164 \\
\hline \multirow[t]{10}{*}{ Sterna hirundo } & Common tern & Spring & Density & 0.0000 & 0.0000 & 0.0000 & 0.0000 & 0.0000 & 0.0000 & 0.0000 & 0.0000 \\
\hline & & & Frequency & 0.0000 & 0.0000 & 0.0000 & 0.0000 & 0.0000 & 0.0000 & 0.0000 & 0.0000 \\
\hline & & Summer & Density & 0.0000 & 0.0000 & 0.0000 & 0.0000 & 0.0000 & 0.0000 & 0.0000 & 0.0000 \\
\hline & & & Frequency & 0.0000 & 0.0000 & 0.0000 & 0.0000 & 0.0000 & 0.0000 & 0.0000 & 0.0000 \\
\hline & & Fall & Density & 0.0000 & 0.0000 & 0.0012 & 0.0012 & 0.0000 & 0.0000 & 0.0000 & 0.0000 \\
\hline & & & Frequency & 0.0000 & 0.0000 & 0.0122 & 0.0122 & 0.0000 & 0.0000 & 0.0000 & 0.0000 \\
\hline & & Winter & Density & 0.0000 & 0.0000 & 0.0000 & 0.0000 & 0.0000 & 0.0000 & 0.0000 & 0.0000 \\
\hline & & & Frequency & 0.0000 & 0.0000 & 0.0000 & 0.0000 & 0.0000 & 0.0000 & 0.0000 & 0.0000 \\
\hline & & Total & Density & 0.0000 & 0.0000 & 0.0004 & 0.0004 & 0.0000 & 0.0000 & 0.0000 & 0.0000 \\
\hline & & & Frequency & 0.0000 & 0.0000 & 0.0035 & 0.0035 & 0.0000 & 0.0000 & 0.0000 & 0.0000 \\
\hline \multirow[t]{9}{*}{ Tringa solitaria } & Solitary sandpiper & Spring & Density & 0.0000 & 0.0000 & 0.0000 & 0.0000 & 0.0000 & 0.0000 & 0.0000 & 0.0000 \\
\hline & & & Frequency & 0.0000 & 0.0000 & 0.0000 & 0.0000 & 0.0000 & 0.0000 & 0.0000 & 0.0000 \\
\hline & & Summer & Density & 0.0000 & 0.0000 & 0.0000 & 0.0000 & 0.0000 & 0.0000 & 0.0000 & 0.0000 \\
\hline & & & Frequency & 0.0000 & 0.0000 & 0.0000 & 0.0000 & 0.0000 & 0.0000 & 0.0000 & 0.0000 \\
\hline & & Fall & Density & 0.0000 & 0.0000 & 0.0000 & 0.0000 & 0.1124 & 0.1124 & 0.0000 & 0.0000 \\
\hline & & & Frequency & 0.0000 & 0.0000 & 0.0000 & 0.0000 & 0.1562 & 0.1562 & 0.0000 & 0.0000 \\
\hline & & Winter & Density & 0.0000 & 0.0000 & 0.0000 & 0.0000 & 0.0000 & 0.0000 & 0.0000 & 0.0000 \\
\hline & & & Frequency & 0.0000 & 0.0000 & 0.0000 & 0.0000 & 0.0000 & 0.0000 & 0.0000 & 0.0000 \\
\hline & & Total & Density & 0.0000 & 0.0000 & 0.0000 & 0.0000 & 0.0321 & 0.0321 & 0.0000 & 0.0000 \\
\hline
\end{tabular}


Appendix H. Continued.

\begin{tabular}{|c|c|c|c|c|c|c|c|c|c|c|c|}
\hline \multirow[b]{3}{*}{ Scientific name } & \multirow[b]{3}{*}{ Common name } & \multirow[b]{3}{*}{ Season } & \multirow[b]{3}{*}{ Measure } & \multicolumn{8}{|c|}{ Treatment } \\
\hline & & & & \multicolumn{2}{|c|}{$\mathrm{BI}$} & \multicolumn{2}{|c|}{$\mathrm{BM}$} & \multicolumn{2}{|c|}{ MI } & \multicolumn{2}{|c|}{$\mathrm{MM}$} \\
\hline & & & & $\bar{x}$ & SE & $\bar{x}$ & SE & $\bar{x}$ & SE & $\bar{x}$ & $\mathrm{SE}$ \\
\hline & & & Frequency & 0.0000 & 0.0000 & 0.0000 & 0.0000 & 0.0446 & 0.0446 & 0.0000 & 0.0000 \\
\hline
\end{tabular}

a Treatments encompassed the length of the associated island and one-half the width of the associated back channel.

b Spring: 21 March-7 April 2001, 23-25 March 2002; summer: 14-28 May, 11-27 June 2002, 16-25 May, 17-26 June, 17 July-13

August 2002; fall: 10-16 November 2001, 28 September-6 October 2002; winter: 26-28 January 2002. 
Appendix I. Density (no. birds/ha) and frequency (no. birds/km) of all waterbird species encountered on back and main channels, and island and mainland sides, averaged by channel and side across years, associated with 10 islands on the Ohio River, West Virginia, USA, 2001-2002.

\begin{tabular}{|c|c|c|c|c|c|c|c|c|c|c|c|}
\hline \multirow[b]{3}{*}{ Scientific name } & \multirow[b]{3}{*}{ Common name } & \multirow[b]{3}{*}{ Season $^{\mathrm{b}}$} & \multirow[b]{3}{*}{ Measure } & \multicolumn{4}{|c|}{ Channel $^{\mathrm{a}}$} & \multicolumn{4}{|c|}{ Side $^{b}$} \\
\hline & & & & \multicolumn{2}{|c|}{ Back } & \multicolumn{2}{|c|}{ Main } & \multicolumn{2}{|c|}{ Island } & \multicolumn{2}{|c|}{ Mainland } \\
\hline & & & & $\bar{x}$ & $\mathrm{SE}$ & $\bar{x}$ & $\mathrm{SE}$ & $\bar{x}$ & SE & $\bar{x}$ & $\mathrm{SE}$ \\
\hline \multirow[t]{10}{*}{ Actitis macularia } & Spotted sandpiper & Spring & Density & 0.0000 & 0.0000 & 0.0000 & 0.0000 & 0.0000 & 0.0000 & 0.0000 & 0.0000 \\
\hline & & & Frequency & 0.0000 & 0.0000 & 0.0000 & 0.0000 & 0.0000 & 0.0000 & 0.0000 & 0.0000 \\
\hline & & Summer & Density & 0.0816 & 0.0339 & 0.0836 & 0.0327 & 0.0427 & 0.0158 & 0.1226 & 0.0434 \\
\hline & & & Frequency & 0.2994 & 0.0903 & 0.3454 & 0.0876 & 0.2010 & 0.0587 & 0.4438 & 0.1079 \\
\hline & & Fall & Density & 0.0000 & 0.0000 & 0.0028 & 0.0028 & 0.0028 & 0.0028 & 0.0000 & 0.0000 \\
\hline & & & Frequency & 0.0000 & 0.0000 & 0.0142 & 0.0142 & 0.0142 & 0.0142 & 0.0000 & 0.0000 \\
\hline & & Winter & Density & 0.0034 & 0.0034 & 0.0000 & 0.0000 & 0.0034 & 0.0034 & 0.0000 & 0.0000 \\
\hline & & & Frequency & 0.0229 & 0.0229 & 0.0000 & 0.0000 & 0.0229 & 0.0229 & 0.0000 & 0.0000 \\
\hline & & Total & Density & 0.0238 & 0.0101 & 0.0247 & 0.0098 & 0.0135 & 0.0048 & 0.0350 & 0.0132 \\
\hline & & & Frequency & 0.0888 & 0.0281 & 0.1027 & 0.0283 & 0.0647 & 0.0189 & 0.1268 & 0.0350 \\
\hline \multirow[t]{10}{*}{ Aix sponsa } & Wood duck & Spring & Density & 0.4374 & 0.1140 & 0.0366 & 0.0146 & 0.3621 & 0.1120 & 0.1120 & 0.0438 \\
\hline & & & Frequency & 2.1977 & 0.6197 & 0.2272 & 0.0867 & 1.8802 & 0.6175 & 0.5446 & 0.1926 \\
\hline & & Summer & Density & 0.5191 & 0.0812 & 0.1593 & 0.0661 & 0.4261 & 0.0957 & 0.2522 & 0.0556 \\
\hline & & & Frequency & 2.4920 & 0.4093 & 0.8054 & 0.2462 & 2.0164 & 0.4405 & 1.2809 & 0.2523 \\
\hline & & Fall & Density & 0.2931 & 0.0946 & 0.1396 & 0.1217 & 0.1770 & 0.0787 & 0.2558 & 0.1333 \\
\hline & & & Frequency & 1.3536 & 0.4436 & 0.9043 & 0.7980 & 0.8977 & 0.4066 & 1.3603 & 0.8174 \\
\hline & & Winter & Density & 0.0000 & 0.0000 & 0.0000 & 0.0000 & 0.0000 & 0.0000 & 0.0000 & 0.0000 \\
\hline & & & Frequency & 0.0000 & 0.0000 & 0.0000 & 0.0000 & 0.0000 & 0.0000 & 0.0000 & 0.0000 \\
\hline & & Total & Density & 0.3570 & 0.0500 & 0.0959 & 0.0398 & 0.2758 & 0.0490 & 0.1771 & 0.0435 \\
\hline & & & Frequency & 1.7266 & 0.2550 & 0.5534 & 0.2396 & 1.3698 & 0.2513 & 0.9102 & 0.2519 \\
\hline \multirow[t]{2}{*}{ Anas americana } & American wigeon & Spring & Density & 0.0045 & 0.0032 & 0.0000 & 0.0000 & 0.0019 & 0.0019 & 0.0026 & 0.0026 \\
\hline & & & Frequency & 0.0537 & 0.0378 & 0.0000 & 0.0000 & 0.0233 & 0.0233 & 0.0303 & 0.0303 \\
\hline
\end{tabular}


Appendix I. Continued.

\begin{tabular}{|c|c|c|c|c|c|c|c|c|c|c|c|}
\hline \multirow[b]{3}{*}{ Scientific name } & \multirow[b]{3}{*}{ Common name } & \multirow[b]{3}{*}{ Season $^{\mathrm{b}}$} & \multirow[b]{3}{*}{ Measure } & \multicolumn{4}{|c|}{ Channel } & \multicolumn{4}{|c|}{ Side } \\
\hline & & & & \multicolumn{2}{|c|}{ Back } & \multicolumn{2}{|c|}{ Main } & \multicolumn{2}{|c|}{ Island } & \multicolumn{2}{|c|}{ Mainland } \\
\hline & & & & $x$ & $\mathrm{SE}$ & $x$ & $\mathrm{SE}$ & $\bar{x}$ & $\mathrm{SE}$ & $x$ & $\mathrm{SE}$ \\
\hline & & Summer & Density & 0.0000 & 0.0000 & 0.0000 & 0.0000 & 0.0000 & 0.0000 & 0.0000 & 0.0000 \\
\hline & & & Frequency & 0.0000 & 0.0000 & 0.0000 & 0.0000 & 0.0000 & 0.0000 & 0.0000 & 0.0000 \\
\hline & & Fall & Density & 0.0000 & 0.0000 & 0.0000 & 0.0000 & 0.0000 & 0.0000 & 0.0000 & 0.0000 \\
\hline & & & Frequency & 0.0000 & 0.0000 & 0.0000 & 0.0000 & 0.0000 & 0.0000 & 0.0000 & 0.0000 \\
\hline & & Winter & Density & 0.0000 & 0.0000 & 0.0000 & 0.0000 & 0.0000 & 0.0000 & 0.0000 & 0.0000 \\
\hline & & & Frequency & 0.0000 & 0.0000 & 0.0000 & 0.0000 & 0.0000 & 0.0000 & 0.0000 & 0.0000 \\
\hline & & Total & Density & 0.0013 & 0.0009 & 0.0000 & 0.0000 & 0.0006 & 0.0006 & 0.0007 & 0.0007 \\
\hline & & & Frequency & 0.0153 & 0.0109 & 0.0000 & 0.0000 & 0.0067 & 0.0067 & 0.0087 & 0.0087 \\
\hline \multirow[t]{10}{*}{ Anas clypeata } & Northern shovelor & Spring & Density & 0.0133 & 0.0133 & 0.0055 & 0.0055 & 0.0188 & 0.0142 & 0.0000 & 0.0000 \\
\hline & & & Frequency & 0.0576 & 0.0576 & 0.0284 & 0.0284 & 0.0860 & 0.0636 & 0.0000 & 0.0000 \\
\hline & & Summer & Density & 0.0000 & 0.0000 & 0.0000 & 0.0000 & 0.0000 & 0.0000 & 0.0000 & 0.0000 \\
\hline & & & Frequency & 0.0000 & 0.0000 & 0.0000 & 0.0000 & 0.0000 & 0.0000 & 0.0000 & 0.0000 \\
\hline & & Fall & Density & 0.0000 & 0.0000 & 0.0000 & 0.0000 & 0.0000 & 0.0000 & 0.0000 & 0.0000 \\
\hline & & & Frequency & 0.0000 & 0.0000 & 0.0000 & 0.0000 & 0.0000 & 0.0000 & 0.0000 & 0.0000 \\
\hline & & Winter & Density & 0.0000 & 0.0000 & 0.0000 & 0.0000 & 0.0000 & 0.0000 & 0.0000 & 0.0000 \\
\hline & & & Frequency & 0.0000 & 0.0000 & 0.0000 & 0.0000 & 0.0000 & 0.0000 & 0.0000 & 0.0000 \\
\hline & & Total & Density & 0.0038 & 0.0038 & 0.0016 & 0.0016 & 0.0054 & 0.0041 & 0.0000 & 0.0000 \\
\hline & & & Frequency & 0.0164 & 0.0164 & 0.0081 & 0.0081 & 0.0246 & 0.0183 & 0.0000 & 0.0000 \\
\hline \multirow[t]{6}{*}{ Anas discors } & Blue-winged teal & Spring & Density & 0.0255 & 0.0145 & 0.0221 & 0.0182 & 0.0260 & 0.0145 & 0.0216 & 0.0182 \\
\hline & & & Frequency & 0.0950 & 0.0566 & 0.1480 & 0.1193 & 0.1007 & 0.0566 & 0.1423 & 0.1194 \\
\hline & & Summer & Density & 0.0000 & 0.0000 & 0.0000 & 0.0000 & 0.0000 & 0.0000 & 0.0000 & 0.0000 \\
\hline & & & Frequency & 0.0000 & 0.0000 & 0.0000 & 0.0000 & 0.0000 & 0.0000 & 0.0000 & 0.0000 \\
\hline & & Fall & Density & 0.0000 & 0.0000 & 0.0000 & 0.0000 & 0.0000 & 0.0000 & 0.0000 & 0.0000 \\
\hline & & & Frequency & 0.0000 & 0.0000 & 0.0000 & 0.0000 & 0.0000 & 0.0000 & 0.0000 & 0.0000 \\
\hline
\end{tabular}


Appendix I. Continued.

\begin{tabular}{|c|c|c|c|c|c|c|c|c|c|c|c|}
\hline \multirow[b]{3}{*}{ Scientific name } & \multirow[b]{3}{*}{ Common name } & \multirow[b]{3}{*}{ Season $^{\mathrm{b}}$} & \multirow[b]{3}{*}{ Measure } & \multicolumn{4}{|c|}{ Channel } & \multicolumn{4}{|c|}{ Side } \\
\hline & & & & \multicolumn{2}{|c|}{ Back } & \multicolumn{2}{|c|}{ Main } & \multicolumn{2}{|c|}{ Island } & \multicolumn{2}{|c|}{ Mainland } \\
\hline & & & & $\bar{x}$ & $\mathrm{SE}$ & $\bar{x}$ & $\mathrm{SE}$ & $\bar{x}$ & $\mathrm{SE}$ & $\bar{x}$ & $\mathrm{SE}$ \\
\hline & & Winter & Density & 0.0000 & 0.0000 & 0.0000 & 0.0000 & 0.0000 & 0.0000 & 0.0000 & 0.0000 \\
\hline & & & Frequency & 0.0000 & 0.0000 & 0.0000 & 0.0000 & 0.0000 & 0.0000 & 0.0000 & 0.0000 \\
\hline & & Total & Density & 0.0073 & 0.0042 & 0.0063 & 0.0052 & 0.0074 & 0.0042 & 0.0062 & 0.0052 \\
\hline & & & Frequency & 0.0271 & 0.0164 & 0.0423 & 0.0342 & 0.0288 & 0.0165 & 0.0406 & 0.0342 \\
\hline \multirow[t]{10}{*}{ Anas platyrhynchos } & Mallard & Spring & Density & 0.3095 & 0.1300 & 0.0530 & 0.0187 & 0.2140 & 0.1144 & 0.1485 & 0.0703 \\
\hline & & & Frequency & 0.9768 & 0.3124 & 0.2467 & 0.0785 & 0.8264 & 0.3020 & 0.3971 & 0.1303 \\
\hline & & Summer & Density & 0.3279 & 0.1666 & 0.0888 & 0.0252 & 0.1185 & 0.0378 & 0.2982 & 0.1652 \\
\hline & & & Frequency & 0.8479 & 0.3567 & 0.4101 & 0.1094 & 0.4119 & 0.1120 & 0.8462 & 0.3560 \\
\hline & & Fall & Density & 0.1080 & 0.0778 & 0.0173 & 0.0118 & 0.0278 & 0.0177 & 0.0976 & 0.0770 \\
\hline & & & Frequency & 0.3429 & 0.1953 & 0.0695 & 0.0438 & 0.1572 & 0.1154 & 0.2552 & 0.1661 \\
\hline & & Winter & Density & 0.1831 & 0.0939 & 0.0065 & 0.0065 & 0.0612 & 0.0391 & 0.1284 & 0.0896 \\
\hline & & & Frequency & 0.5950 & 0.2140 & 0.0685 & 0.0685 & 0.2851 & 0.1392 & 0.3784 & 0.1954 \\
\hline & & Total & Density & 0.2391 & 0.0656 & 0.0464 & 0.0099 & 0.1117 & 0.0354 & 0.1738 & 0.0571 \\
\hline & & & Frequency & 0.7043 & 0.1498 & 0.2173 & 0.0429 & 0.4394 & 0.1013 & 0.4822 & 0.1220 \\
\hline \multirow[t]{10}{*}{ Anas rubripes } & American black duck & Spring & Density & 0.0129 & 0.0090 & 0.0038 & 0.0033 & 0.0167 & 0.0094 & 0.0000 & 0.0000 \\
\hline & & & Frequency & 0.0423 & 0.0315 & 0.0129 & 0.0090 & 0.0552 & 0.0323 & 0.0000 & 0.0000 \\
\hline & & Summer & Density & 0.0000 & 0.0000 & 0.0000 & 0.0000 & 0.0000 & 0.0000 & 0.0000 & 0.0000 \\
\hline & & & Frequency & 0.0000 & 0.0000 & 0.0000 & 0.0000 & 0.0000 & 0.0000 & 0.0000 & 0.0000 \\
\hline & & Fall & Density & 0.0391 & 0.0274 & 0.0000 & 0.0000 & 0.0207 & 0.0207 & 0.0184 & 0.0184 \\
\hline & & & Frequency & 0.1177 & 0.0822 & 0.0000 & 0.0000 & 0.0584 & 0.0584 & 0.0593 & 0.0593 \\
\hline & & Winter & Density & 0.0000 & 0.0000 & 0.0022 & 0.0022 & 0.0022 & 0.0022 & 0.0000 & 0.0000 \\
\hline & & & Frequency & 0.0000 & 0.0000 & 0.0228 & 0.0228 & 0.0228 & 0.0228 & 0.0000 & 0.0000 \\
\hline & & Total & Density & 0.0148 & 0.0083 & 0.0014 & 0.0010 & 0.0110 & 0.0065 & 0.0052 & 0.0052 \\
\hline & & & Frequency & 0.0457 & 0.0252 & 0.0069 & 0.0042 & 0.0357 & 0.0193 & 0.0169 & 0.0169 \\
\hline
\end{tabular}


Appendix I. Continued.

\begin{tabular}{|c|c|c|c|c|c|c|c|c|c|c|c|}
\hline \multirow[b]{3}{*}{ Scientific name } & \multirow[b]{3}{*}{ Common name } & \multirow[b]{3}{*}{ Season $^{\mathrm{b}}$} & \multirow[b]{3}{*}{ Measure } & \multicolumn{4}{|c|}{ Channel } & \multicolumn{4}{|c|}{ Side } \\
\hline & & & & \multicolumn{2}{|c|}{ Back } & \multicolumn{2}{|c|}{ Main } & \multicolumn{2}{|c|}{ Island } & \multicolumn{2}{|c|}{ Mainland } \\
\hline & & & & $\bar{x}$ & SE & $\bar{x}$ & SE & $x$ & SE & $\bar{x}$ & SE \\
\hline \multirow[t]{10}{*}{ Anas strepera } & Gadwall $^{c}$ & Spring & Density & 0.0000 & 0.0000 & 0.0000 & 0.0000 & 0.0000 & 0.0000 & 0.0000 & 0.0000 \\
\hline & & & Frequency & 0.0000 & 0.0000 & 0.0000 & 0.0000 & 0.0000 & 0.0000 & 0.0000 & 0.0000 \\
\hline & & Summer & Density & 0.0000 & 0.0000 & 0.0000 & 0.0000 & 0.0000 & 0.0000 & 0.0000 & 0.0000 \\
\hline & & & Frequency & 0.0000 & 0.0000 & 0.0000 & 0.0000 & 0.0000 & 0.0000 & 0.0000 & 0.0000 \\
\hline & & Fall & Density & 0.0000 & 0.0000 & 0.0000 & 0.0000 & 0.0000 & 0.0000 & 0.0000 & 0.0000 \\
\hline & & & Frequency & 0.0000 & 0.0000 & 0.0000 & 0.0000 & 0.0000 & 0.0000 & 0.0000 & 0.0000 \\
\hline & & Winter & Density & $\mathrm{n} \backslash \mathrm{a}$ & $\mathrm{n} \backslash \mathrm{a}$ & $\mathrm{n} \backslash \mathrm{a}$ & $\mathrm{n} \backslash \mathrm{a}$ & $\mathrm{n} \backslash \mathrm{a}$ & $\mathrm{n} \backslash \mathrm{a}$ & $\mathrm{n} \backslash \mathrm{a}$ & $\mathrm{n} \backslash \mathrm{a}$ \\
\hline & & & Frequency & 0.0000 & 0.0000 & 0.0287 & 0.0287 & $\mathrm{n} \backslash \mathrm{a}$ & $\mathrm{n} \backslash \mathrm{a}$ & $\mathrm{n} \backslash \mathrm{a}$ & $\mathrm{n} \backslash \mathrm{a}$ \\
\hline & & Total & Density & & $\mathrm{n} \backslash \mathrm{a}$ & $\mathrm{n} \backslash \mathrm{a}$ & $\mathrm{n} \backslash \mathrm{a}$ & $\mathrm{n} \backslash \mathrm{a}$ & $\mathrm{n} \backslash \mathrm{a}$ & $\mathrm{n} \backslash \mathrm{a}$ & $\mathrm{n} \backslash \mathrm{a}$ \\
\hline & & & Frequency & 0.0000 & 0.0000 & 0.0041 & 0.0041 & $\mathrm{n} \backslash \mathrm{a}$ & $n \backslash \mathrm{a}$ & $\mathrm{n} \backslash \mathrm{a}$ & $\mathrm{n} \backslash \mathrm{a}$ \\
\hline \multirow[t]{10}{*}{ Ardea herodias } & Great blue heron & Spring & Density & 0.0888 & 0.0330 & 0.0284 & 0.0104 & 0.0863 & 0.0299 & 0.0308 & 0.0175 \\
\hline & & & Frequency & 0.5497 & 0.2074 & 0.1983 & 0.0647 & 0.5561 & 0.1853 & 0.1919 & 0.1130 \\
\hline & & Summer & Density & 0.1490 & 0.0492 & 0.1013 & 0.0329 & 0.1515 & 0.0442 & 0.0988 & 0.0393 \\
\hline & & & Frequency & 0.4928 & 0.1671 & 0.3856 & 0.0724 & 0.5806 & 0.1660 & 0.2978 & 0.0687 \\
\hline & & Fall & Density & 0.1195 & 0.0315 & 0.1176 & 0.0367 & 0.1708 & 0.0366 & 0.0662 & 0.0293 \\
\hline & & & Frequency & 0.5358 & 0.0988 & 0.4850 & 0.1126 & 0.7415 & 0.1078 & 0.2793 & 0.0901 \\
\hline & & Winter & Density & 0.1362 & 0.0460 & 0.0515 & 0.0181 & 0.1318 & 0.0463 & 0.0559 & 0.0184 \\
\hline & & & Frequency & 0.9426 & 0.3918 & 0.2797 & 0.0786 & 0.9276 & 0.3931 & 0.2946 & 0.0785 \\
\hline & & Total & Density & 0.1215 & 0.0202 & 0.0780 & 0.0148 & 0.1356 & 0.0196 & 0.0639 & 0.0151 \\
\hline & & & Frequency & 0.5856 & 0.0981 & 0.3454 & 0.0446 & 0.6692 & 0.0950 & 0.2618 & 0.0468 \\
\hline \multirow[t]{2}{*}{ Aythya americana } & Redhead & Spring & Density & 0.0000 & 0.0000 & 0.0082 & 0.0082 & 0.0000 & 0.0000 & 0.0082 & 0.0082 \\
\hline & & & Frequency & 0.0000 & 0.0000 & 0.0832 & 0.0832 & 0.0000 & 0.0000 & 0.0832 & 0.0832 \\
\hline
\end{tabular}


Appendix I. Continued.

\begin{tabular}{|c|c|c|c|c|c|c|c|c|c|c|c|}
\hline \multirow[b]{3}{*}{ Scientific name } & \multirow[b]{3}{*}{ Common name } & \multirow[b]{3}{*}{ Season $^{b}$} & \multirow[b]{3}{*}{ Measure } & \multicolumn{4}{|c|}{ Channel } & \multicolumn{4}{|c|}{ Side } \\
\hline & & & & \multicolumn{2}{|c|}{ Back } & \multicolumn{2}{|c|}{ Main } & \multicolumn{2}{|c|}{ Island } & \multicolumn{2}{|c|}{ Mainland } \\
\hline & & & & $x$ & $\mathrm{SE}$ & $x$ & SE & $\bar{x}$ & $\mathrm{SE}$ & $x$ & $\mathrm{SE}$ \\
\hline & & Summer & Density & 0.0000 & 0.0000 & 0.0000 & 0.0000 & 0.0000 & 0.0000 & 0.0000 & 0.0000 \\
\hline & & & Frequency & 0.0000 & 0.0000 & 0.0000 & 0.0000 & 0.0000 & 0.0000 & 0.0000 & 0.0000 \\
\hline & & Fall & Density & 0.0000 & 0.0000 & 0.0000 & 0.0000 & 0.0000 & 0.0000 & 0.0000 & 0.0000 \\
\hline & & & Frequency & 0.0000 & 0.0000 & 0.0000 & 0.0000 & 0.0000 & 0.0000 & 0.0000 & 0.0000 \\
\hline & & Winter & Density & 0.0000 & 0.0000 & 0.0000 & 0.0000 & 0.0000 & 0.0000 & 0.0000 & 0.0000 \\
\hline & & & Frequency & 0.0000 & 0.0000 & 0.0000 & 0.0000 & 0.0000 & 0.0000 & 0.0000 & 0.0000 \\
\hline & & Total & Density & 0.0000 & 0.0000 & 0.0023 & 0.0023 & 0.0000 & 0.0000 & 0.0023 & 0.0023 \\
\hline & & & Frequency & 0.0000 & 0.0000 & 0.0238 & 0.0238 & 0.0000 & 0.0000 & 0.0238 & 0.0238 \\
\hline \multirow[t]{10}{*}{ Aythya collaris } & Ring-necked duck & Spring & Density & 0.0000 & 0.0000 & 0.0000 & 0.0000 & 0.0000 & 0.0000 & 0.0000 & 0.0000 \\
\hline & & & Frequency & 0.0000 & 0.0000 & 0.0000 & 0.0000 & 0.0000 & 0.0000 & 0.0000 & 0.0000 \\
\hline & & Summer & Density & 0.0000 & 0.0000 & 0.0000 & 0.0000 & 0.0000 & 0.0000 & 0.0000 & 0.0000 \\
\hline & & & Frequency & 0.0000 & 0.0000 & 0.0000 & 0.0000 & 0.0000 & 0.0000 & 0.0000 & 0.0000 \\
\hline & & Fall & Density & 0.0000 & 0.0000 & 0.0000 & 0.0000 & 0.0000 & 0.0000 & 0.0000 & 0.0000 \\
\hline & & & Frequency & 0.0000 & 0.0000 & 0.0000 & 0.0000 & 0.0000 & 0.0000 & 0.0000 & 0.0000 \\
\hline & & Winter & Density & 0.0034 & 0.0034 & 0.0000 & 0.0000 & 0.0034 & 0.0034 & 0.0000 & 0.0000 \\
\hline & & & Frequency & 0.0229 & 0.0229 & 0.0000 & 0.0000 & 0.0229 & 0.0229 & 0.0000 & 0.0000 \\
\hline & & Total & Density & 0.0005 & 0.0005 & 0.0000 & 0.0000 & 0.0005 & 0.0005 & 0.0000 & 0.0000 \\
\hline & & & Frequency & 0.0033 & 0.0033 & 0.0000 & 0.0000 & 0.0033 & 0.0033 & 0.0000 & 0.0000 \\
\hline \multirow[t]{6}{*}{ Aythya spp. } & Scaup spp. & Spring & Density & 0.0705 & 0.0367 & 0.0630 & 0.0549 & 0.0581 & 0.0338 & 0.0753 & 0.0567 \\
\hline & & & Frequency & 0.6215 & 0.3178 & 0.2162 & 0.1628 & 0.4686 & 0.2653 & 0.3691 & 0.2432 \\
\hline & & Summer & Density & 0.0000 & 0.0000 & 0.0000 & 0.0000 & 0.0000 & 0.0000 & 0.0000 & 0.0000 \\
\hline & & & Frequency & 0.0000 & 0.0000 & 0.0000 & 0.0000 & 0.0000 & 0.0000 & 0.0000 & 0.0000 \\
\hline & & Fall & Density & 0.0075 & 0.0075 & 0.0000 & 0.0000 & 0.0075 & 0.0075 & 0.0000 & 0.0000 \\
\hline & & & Frequency & 0.0457 & 0.0457 & 0.0000 & 0.0000 & 0.0457 & 0.0457 & 0.0000 & 0.0000 \\
\hline
\end{tabular}


Appendix I. Continued.

\begin{tabular}{|c|c|c|c|c|c|c|c|c|c|c|c|}
\hline \multirow[b]{3}{*}{ Scientific name } & \multirow[b]{3}{*}{ Common name } & \multirow[b]{3}{*}{ Season $^{\mathrm{b}}$} & \multirow[b]{3}{*}{ Measure } & \multicolumn{4}{|c|}{ Channel } & \multicolumn{4}{|c|}{ Side } \\
\hline & & & & \multicolumn{2}{|c|}{ Back } & \multicolumn{2}{|c|}{ Main } & \multicolumn{2}{|c|}{ Island } & \multicolumn{2}{|c|}{ Mainland } \\
\hline & & & & $\bar{x}$ & $\mathrm{SE}$ & $x$ & $\mathrm{SE}$ & $\bar{x}$ & $\mathrm{SE}$ & $\bar{x}$ & SE \\
\hline & & Winter & Density & 0.0000 & 0.0000 & 0.0095 & 0.0076 & 0.0022 & 0.0022 & 0.0074 & 0.0074 \\
\hline & & & Frequency & 0.0000 & 0.0000 & 0.0727 & 0.0537 & 0.0228 & 0.0228 & 0.0498 & 0.0498 \\
\hline & & Total & Density & 0.0223 & 0.0109 & 0.0194 & 0.0158 & 0.0191 & 0.0100 & 0.0226 & 0.0163 \\
\hline & & & Frequency & 0.1906 & 0.0938 & 0.0722 & 0.0474 & 0.1502 & 0.0782 & 0.1126 & 0.0706 \\
\hline \multirow[t]{10}{*}{ Branta canadensis } & Canada goose & Spring & Density & 0.6170 & 0.1421 & 0.5645 & 0.1090 & 0.7079 & 0.1241 & 0.4736 & 0.1265 \\
\hline & & & Frequency & 2.8236 & 0.6033 & 2.8890 & 0.4892 & 3.7971 & 0.6534 & 1.9155 & 0.3620 \\
\hline & & Summer & Density & 0.8255 & 0.3180 & 1.5115 & 0.6153 & 0.6727 & 0.4084 & 1.6643 & 0.5535 \\
\hline & & & Frequency & 3.7676 & 1.5192 & 5.5817 & 2.0440 & 2.7028 & 1.2204 & 6.6464 & 2.1999 \\
\hline & & Fall & Density & 0.0349 & 0.0280 & 0.0871 & 0.0654 & 0.0327 & 0.0233 & 0.0893 & 0.0672 \\
\hline & & & Frequency & 0.1329 & 0.1004 & 0.3131 & 0.2010 & 0.2394 & 0.1476 & 0.2066 & 0.1706 \\
\hline & & Winter & Density & 1.1006 & 0.4796 & 0.3176 & 0.1714 & 0.4910 & 0.2404 & 0.9272 & 0.4612 \\
\hline & & & Frequency & 4.8324 & 1.9371 & 2.0540 & 1.3826 & 2.7149 & 1.3598 & 4.1715 & 1.9905 \\
\hline & & Total & Density & 0.5793 & 0.1237 & 0.6634 & 0.1858 & 0.4740 & 0.1280 & 0.7688 & 0.1821 \\
\hline & & & Frequency & 2.6115 & 0.5557 & 2.8031 & 0.6511 & 2.3134 & 0.4531 & 3.1012 & 0.7248 \\
\hline \multirow[t]{10}{*}{ Bucephala albeola } & Bufflehead & Spring & Density & 0.0424 & 0.0412 & 0.0180 & 0.0103 & 0.0533 & 0.0416 & 0.0071 & 0.0071 \\
\hline & & & Frequency & 0.2671 & 0.2517 & 0.0860 & 0.0534 & 0.3272 & 0.2545 & 0.0260 & 0.0260 \\
\hline & & Summer & Density & 0.0000 & 0.0000 & 0.0000 & 0.0000 & 0.0000 & 0.0000 & 0.0000 & 0.0000 \\
\hline & & & Frequency & 0.0000 & 0.0000 & 0.0000 & 0.0000 & 0.0000 & 0.0000 & 0.0000 & 0.0000 \\
\hline & & Fall & Density & 0.0000 & 0.0000 & 0.0016 & 0.0016 & 0.0000 & 0.0000 & 0.0016 & 0.0016 \\
\hline & & & Frequency & 0.0000 & 0.0000 & 0.0166 & 0.0166 & 0.0000 & 0.0000 & 0.0166 & 0.0166 \\
\hline & & Winter & Density & 0.0000 & 0.0000 & 0.0065 & 0.0065 & 0.0065 & 0.0065 & 0.0000 & 0.0000 \\
\hline & & & Frequency & 0.0000 & 0.0000 & 0.0144 & 0.0144 & 0.0144 & 0.0144 & 0.0000 & 0.0000 \\
\hline & & Total & Density & 0.0121 & 0.0118 & 0.0065 & 0.0032 & 0.0162 & 0.0120 & 0.0025 & 0.0021 \\
\hline & & & Frequency & 0.0763 & 0.072 & 0.0314 & 0.0162 & 0.0955 & 0.0732 & 0.0122 & 0.0088 \\
\hline
\end{tabular}


Appendix I. Continued.

\begin{tabular}{|c|c|c|c|c|c|c|c|c|c|c|c|}
\hline \multirow[b]{3}{*}{ Scientific name } & \multirow[b]{3}{*}{ Common name } & \multirow[b]{3}{*}{ Season $^{\mathrm{b}}$} & \multirow[b]{3}{*}{ Measure } & \multicolumn{4}{|c|}{ Channel } & \multicolumn{4}{|c|}{ Side } \\
\hline & & & & \multicolumn{2}{|c|}{ Back } & \multicolumn{2}{|c|}{ Main } & \multicolumn{2}{|c|}{ Island } & \multicolumn{2}{|c|}{ Mainland } \\
\hline & & & & $\bar{x}$ & SE & $\bar{x}$ & SE & $\bar{x}$ & SE & $\bar{x}$ & SE \\
\hline & Bufflehead $^{\mathrm{d}}$ & Spring & Density & $\mathrm{n} / \mathrm{a}$ & $\mathrm{n} / \mathrm{a}$ & $\mathrm{n} / \mathrm{a}$ & $\mathrm{n} / \mathrm{a}$ & $\mathrm{n} / \mathrm{a}$ & $\mathrm{n} / \mathrm{a}$ & $\mathrm{n} / \mathrm{a}$ & $\mathrm{n} / \mathrm{a}$ \\
\hline & & & Frequency & 0.2671 & 0.2517 & 0.7003 & 0.6144 & $\mathrm{n} / \mathrm{a}$ & $\mathrm{n} / \mathrm{a}$ & $\mathrm{n} / \mathrm{a}$ & $\mathrm{n} / \mathrm{a}$ \\
\hline & & Summer & Density & $\mathrm{n} / \mathrm{a}$ & $\mathrm{n} / \mathrm{a}$ & $\mathrm{n} / \mathrm{a}$ & $\mathrm{n} / \mathrm{a}$ & $\mathrm{n} / \mathrm{a}$ & $\mathrm{n} / \mathrm{a}$ & $\mathrm{n} / \mathrm{a}$ & $\mathrm{n} / \mathrm{a}$ \\
\hline & & & Frequency & 0.0000 & 0.0000 & 0.0000 & 0.0000 & $\mathrm{n} / \mathrm{a}$ & $\mathrm{n} / \mathrm{a}$ & $\mathrm{n} / \mathrm{a}$ & $\mathrm{n} / \mathrm{a}$ \\
\hline & & Fall & Density & $\mathrm{n} / \mathrm{a}$ & $\mathrm{n} / \mathrm{a}$ & $\mathrm{n} / \mathrm{a}$ & $\mathrm{n} / \mathrm{a}$ & $\mathrm{n} / \mathrm{a}$ & $\mathrm{n} / \mathrm{a}$ & $\mathrm{n} / \mathrm{a}$ & $\mathrm{n} / \mathrm{a}$ \\
\hline & & & Frequency & 0.0000 & 0.0000 & 0.0166 & 0.0166 & $\mathrm{n} / \mathrm{a}$ & $\mathrm{n} / \mathrm{a}$ & $\mathrm{n} / \mathrm{a}$ & $\mathrm{n} / \mathrm{a}$ \\
\hline & & Winter & Density & $\mathrm{n} / \mathrm{a}$ & $\mathrm{n} / \mathrm{a}$ & $\mathrm{n} / \mathrm{a}$ & $\mathrm{n} / \mathrm{a}$ & $\mathrm{n} / \mathrm{a}$ & $\mathrm{n} / \mathrm{a}$ & $\mathrm{n} / \mathrm{a}$ & $\mathrm{n} / \mathrm{a}$ \\
\hline & & & Frequency & 0.0000 & 0.0000 & 0.0144 & 0.0144 & $\mathrm{n} / \mathrm{a}$ & $\mathrm{n} / \mathrm{a}$ & $\mathrm{n} / \mathrm{a}$ & $\mathrm{n} / \mathrm{a}$ \\
\hline & & Total & Density & $\mathrm{n} / \mathrm{a}$ & $\mathrm{n} / \mathrm{a}$ & $\mathrm{n} / \mathrm{a}$ & $\mathrm{n} / \mathrm{a}$ & $\mathrm{n} / \mathrm{a}$ & $\mathrm{n} / \mathrm{a}$ & $\mathrm{n} / \mathrm{a}$ & $\mathrm{n} / \mathrm{a}$ \\
\hline & & & Frequency & 0.0763 & 0.0720 & 0.2069 & 0.1760 & $\mathrm{n} / \mathrm{a}$ & $\mathrm{n} / \mathrm{a}$ & $\mathrm{n} / \mathrm{a}$ & $\mathrm{n} / \mathrm{a}$ \\
\hline \multirow[t]{10}{*}{ Butorides virescens } & Green heron & Spring & Density & 0.0000 & 0.0000 & 0.0000 & 0.0000 & 0.0000 & 0.0000 & 0.0000 & 0.0000 \\
\hline & & & Frequency & 0.0000 & 0.0000 & 0.0000 & 0.0000 & 0.0000 & 0.0000 & 0.0000 & 0.0000 \\
\hline & & Summer & Density & 0.0259 & 0.0091 & 0.0056 & 0.0037 & 0.0106 & 0.0056 & 0.0210 & 0.0083 \\
\hline & & & Frequency & 0.1222 & 0.0415 & 0.0253 & 0.0151 & 0.0502 & 0.0278 & 0.0974 & 0.0357 \\
\hline & & Fall & Density & 0.0292 & 0.0261 & 0.0661 & 0.0597 & 0.0357 & 0.0268 & 0.0595 & 0.0595 \\
\hline & & & Frequency & 0.0464 & 0.0401 & 0.1130 & 0.0993 & 0.0608 & 0.0422 & 0.0986 & 0.0986 \\
\hline & & Winter & Density & 0.0000 & 0.0000 & 0.0000 & 0.0000 & 0.0000 & 0.0000 & 0.0000 & 0.0000 \\
\hline & & & Frequency & 0.0000 & 0.0000 & 0.0000 & 0.0000 & 0.0000 & 0.0000 & 0.0000 & 0.0000 \\
\hline & & Total & Density & 0.0157 & 0.0079 & 0.0205 & 0.0172 & 0.0132 & 0.0078 & 0.0230 & 0.0171 \\
\hline & & & Frequency & 0.0482 & 0.0169 & 0.0395 & 0.0287 & 0.0317 & 0.0145 & 0.0560 & 0.0300 \\
\hline Ceryle alcyon & Belted kingfisher & Spring & Density & 0.0258 & 0.0104 & 0.0873 & 0.0597 & 0.0234 & 0.0107 & 0.0897 & 0.0596 \\
\hline & & & Frequency & 0.1340 & 0.0464 & 0.2409 & 0.1071 & 0.1228 & 0.0504 & 0.2520 & 0.1050 \\
\hline
\end{tabular}


Appendix I. Continued.

\begin{tabular}{|c|c|c|c|c|c|c|c|c|c|c|c|}
\hline \multirow[b]{3}{*}{ Scientific name } & \multirow[b]{3}{*}{ Common name } & \multirow[b]{3}{*}{ Season $^{\mathrm{b}}$} & \multirow[b]{3}{*}{ Measure } & \multicolumn{4}{|c|}{ Channel } & \multicolumn{4}{|c|}{ Side } \\
\hline & & & & \multicolumn{2}{|c|}{ Back } & \multicolumn{2}{|c|}{ Main } & \multicolumn{2}{|c|}{ Island } & \multicolumn{2}{|c|}{ Mainland } \\
\hline & & & & $\bar{x}$ & $\mathrm{SE}$ & $\bar{x}$ & SE & $\bar{x}$ & $\mathrm{SE}$ & $\bar{x}$ & $\mathrm{SE}$ \\
\hline & & Summer & Density & 0.0939 & 0.0322 & 0.3383 & 0.1093 & 0.1267 & 0.0359 & 0.3055 & 0.1098 \\
\hline & & & Frequency & 0.3468 & 0.0852 & 0.9525 & 0.1908 & 0.4546 & 0.0883 & 0.8446 & 0.1965 \\
\hline & & Fall & Density & 0.1343 & 0.0564 & 0.1739 & 0.0440 & 0.1267 & 0.0352 & 0.1814 & 0.0621 \\
\hline & & & Frequency & 0.4328 & 0.1061 & 0.6026 & 0.1034 & 0.4834 & 0.0962 & 0.5520 & 0.1140 \\
\hline & & Winter & Density & 0.0776 & 0.0522 & 0.1355 & 0.0788 & 0.1235 & 0.0740 & 0.0897 & 0.0592 \\
\hline & & & Frequency & 0.2070 & 0.0946 & 0.3032 & 0.1269 & 0.2434 & 0.1147 & 0.2667 & 0.1102 \\
\hline & & Total & Density & 0.0837 & 0.0203 & 0.1906 & 0.0399 & 0.0967 & 0.0183 & 0.1776 & 0.0411 \\
\hline & & & Frequency & 0.2906 & 0.0440 & 0.5564 & 0.0749 & 0.3379 & 0.0448 & 0.5092 & 0.0754 \\
\hline \multirow[t]{10}{*}{ Charadrius vociferus } & Killdeer & Spring & Density & 0.0017 & 0.0017 & 0.0036 & 0.0036 & 0.0017 & 0.0017 & 0.0036 & 0.0036 \\
\hline & & & Frequency & 0.0114 & 0.0114 & 0.0130 & 0.0130 & 0.0114 & 0.0114 & 0.0130 & 0.0130 \\
\hline & & Summer & Density & 0.0220 & 0.0164 & 0.0332 & 0.0252 & 0.0047 & 0.0036 & 0.0505 & 0.0294 \\
\hline & & & Frequency & 0.0688 & 0.0415 & 0.1225 & 0.0920 & 0.0185 & 0.0133 & 0.1727 & 0.0987 \\
\hline & & Fall & Density & 0.0000 & 0.0000 & 0.1824 & 0.1501 & 0.0056 & 0.0056 & 0.1765 & 0.1502 \\
\hline & & & Frequency & 0.0000 & 0.0000 & 0.4054 & 0.2632 & 0.0454 & 0.0454 & 0.3600 & 0.2608 \\
\hline & & Winter & Density & 0.0000 & 0.0000 & 0.0000 & 0.0000 & 0.0000 & 0.0000 & 0.0000 & 0.0000 \\
\hline & & & Frequency & 0.0000 & 0.0000 & 0.0000 & 0.0000 & 0.0000 & 0.0000 & 0.0000 & 0.0000 \\
\hline & & Total & Density & 0.0068 & 0.0047 & 0.0626 & 0.0436 & 0.0035 & 0.002 & 0.0659 & 0.0438 \\
\hline & & & Frequency & 0.0229 & 0.0124 & 0.1545 & 0.0802 & 0.0215 & 0.0138 & 0.1559 & 0.0800 \\
\hline \multirow[t]{6}{*}{ Fulica americana } & American coot & Spring & Density & 0.0046 & 0.0046 & 0.0075 & 0.0052 & 0.0121 & 0.0069 & 0.0000 & 0.0000 \\
\hline & & & Frequency & 0.0145 & 0.0145 & 0.0394 & 0.0287 & 0.0539 & 0.0317 & 0.0000 & 0.0000 \\
\hline & & Summer & Density & 0.0000 & 0.0000 & 0.0000 & 0.0000 & 0.0000 & 0.0000 & 0.0000 & 0.0000 \\
\hline & & & Frequency & 0.0000 & 0.0000 & 0.0000 & 0.0000 & 0.0000 & 0.0000 & 0.0000 & 0.0000 \\
\hline & & Fall & Density & 0.0000 & 0.0000 & 0.0000 & 0.0000 & 0.0000 & 0.0000 & 0.0000 & 0.0000 \\
\hline & & & Frequency & 0.0000 & 0.0000 & 0.0000 & 0.0000 & 0.0000 & 0.0000 & 0.0000 & 0.0000 \\
\hline
\end{tabular}


Appendix I. Continued.

\begin{tabular}{|c|c|c|c|c|c|c|c|c|c|c|c|}
\hline \multirow[b]{3}{*}{ Scientific name } & \multirow[b]{3}{*}{ Common name } & \multirow[b]{3}{*}{ Season $^{\mathrm{b}}$} & \multirow[b]{3}{*}{ Measure } & \multicolumn{4}{|c|}{ Channel } & \multicolumn{4}{|c|}{ Side } \\
\hline & & & & \multicolumn{2}{|c|}{ Back } & \multicolumn{2}{|c|}{ Main } & \multicolumn{2}{|c|}{ Island } & \multicolumn{2}{|c|}{ Mainland } \\
\hline & & & & $\bar{x}$ & $\mathrm{SE}$ & $x$ & $\mathrm{SE}$ & $\bar{x}$ & $\mathrm{SE}$ & $\bar{x}$ & $\mathrm{SE}$ \\
\hline & & Winter & Density & 0.0000 & 0.0000 & 0.0000 & 0.0000 & 0.0000 & 0.0000 & 0.0000 & 0.0000 \\
\hline & & & Frequency & 0.0000 & 0.0000 & 0.0000 & 0.0000 & 0.0000 & 0.0000 & 0.0000 & 0.0000 \\
\hline & & Total & Density & 0.0013 & 0.0013 & 0.0021 & 0.0015 & 0.0035 & 0.0020 & 0.0000 & 0.0000 \\
\hline & & & Frequency & 0.0042 & 0.0042 & 0.0113 & 0.0082 & 0.0154 & 0.0092 & 0.0000 & 0.0000 \\
\hline \multirow[t]{10}{*}{ Gavia immer } & Common loon & Spring & Density & 0.0000 & 0.0000 & 0.0000 & 0.0000 & 0.0000 & 0.0000 & 0.0000 & 0.0000 \\
\hline & & & Frequency & 0.0000 & 0.0000 & 0.0000 & 0.0000 & 0.0000 & 0.0000 & 0.0000 & 0.0000 \\
\hline & & Summer & Density & 0.0000 & 0.0000 & 0.0000 & 0.0000 & 0.0000 & 0.0000 & 0.0000 & 0.0000 \\
\hline & & & Frequency & 0.0000 & 0.0000 & 0.0000 & 0.0000 & 0.0000 & 0.0000 & 0.0000 & 0.0000 \\
\hline & & Fall & Density & 0.0013 & 0.0013 & 0.0000 & 0.0000 & 0.0000 & 0.0000 & 0.0013 & 0.0013 \\
\hline & & & Frequency & 0.0152 & 0.0152 & 0.0000 & 0.0000 & 0.0000 & 0.0000 & 0.0152 & 0.0152 \\
\hline & & Winter & Density & 0.0000 & 0.0000 & 0.0000 & 0.0000 & 0.0000 & 0.0000 & 0.0000 & 0.0000 \\
\hline & & & Frequency & 0.0000 & 0.0000 & 0.0000 & 0.0000 & 0.0000 & 0.0000 & 0.0000 & 0.0000 \\
\hline & & Total & Density & 0.0004 & 0.0004 & 0.0000 & 0.0000 & 0.0000 & 0.0000 & 0.0004 & 0.0004 \\
\hline & & & Frequency & 0.0043 & 0.0043 & 0.0000 & 0.0000 & 0.0000 & 0.0000 & 0.0043 & 0.0043 \\
\hline \multirow[t]{10}{*}{ Larus delawarensis } & Ring-billed gull & Spring & Density & 0.0000 & 0.0000 & 0.0403 & 0.0212 & 0.0162 & 0.0147 & 0.0241 & 0.0159 \\
\hline & & & Frequency & 0.0000 & 0.0000 & 0.3012 & 0.1636 & 0.1248 & 0.1138 & 0.1763 & 0.1222 \\
\hline & & Summer & Density & 0.0000 & 0.0000 & 0.0000 & 0.0000 & 0.0000 & 0.0000 & 0.0000 & 0.0000 \\
\hline & & & Frequency & 0.0000 & 0.0000 & 0.0000 & 0.0000 & 0.0000 & 0.0000 & 0.0000 & 0.0000 \\
\hline & & Fall & Density & 0.0000 & 0.0000 & 0.0000 & 0.0000 & 0.0000 & 0.0000 & 0.0000 & 0.0000 \\
\hline & & & Frequency & 0.0000 & 0.0000 & 0.0000 & 0.0000 & 0.0000 & 0.0000 & 0.0000 & 0.0000 \\
\hline & & Winter & Density & 0.0000 & 0.0000 & 0.0074 & 0.0074 & 0.0000 & 0.0000 & 0.0074 & 0.0074 \\
\hline & & & Frequency & 0.0000 & 0.0000 & 0.0498 & 0.0498 & 0.0000 & 0.0000 & 0.0498 & 0.0498 \\
\hline & & Total & Density & 0.0000 & 0.0000 & 0.0126 & 0.0063 & 0.0046 & 0.0042 & 0.0079 & 0.0047 \\
\hline & & & Frequency & 0.0000 & 0.0000 & 0.0932 & 0.0482 & 0.0357 & 0.0326 & 0.0575 & 0.0359 \\
\hline
\end{tabular}


Appendix I. Continued.

\begin{tabular}{|c|c|c|c|c|c|c|c|c|c|c|c|}
\hline \multirow[b]{3}{*}{$\underline{\text { Scientific name }}$} & \multirow[b]{3}{*}{ Common name } & \multirow[b]{3}{*}{ Season $^{\mathrm{b}}$} & \multirow[b]{3}{*}{ Measure } & \multicolumn{4}{|c|}{ Channel } & \multicolumn{4}{|c|}{ Side } \\
\hline & & & & \multicolumn{2}{|c|}{ Back } & \multicolumn{2}{|c|}{ Main } & \multicolumn{2}{|c|}{ Island } & \multicolumn{2}{|c|}{ Mainland } \\
\hline & & & & $\bar{x}$ & SE & $x$ & SE & $\bar{x}$ & SE & $\bar{x}$ & SE \\
\hline & Ring-billed gull $^{\mathrm{d}}$ & Spring & Density & $\mathrm{n} / \mathrm{a}$ & $\mathrm{n} / \mathrm{a}$ & $\mathrm{n} / \mathrm{a}$ & $\mathrm{n} / \mathrm{a}$ & $\mathrm{n} / \mathrm{a}$ & $\mathrm{n} / \mathrm{a}$ & $\mathrm{n} / \mathrm{a}$ & $\mathrm{n} / \mathrm{a}$ \\
\hline & & & Frequency & 0.0000 & 0.0000 & 0.3012 & 0.1636 & $\mathrm{n} / \mathrm{a}$ & $\mathrm{n} / \mathrm{a}$ & $\mathrm{n} / \mathrm{a}$ & $\mathrm{n} / \mathrm{a}$ \\
\hline & & Summer & Density & $\mathrm{n} / \mathrm{a}$ & $\mathrm{n} / \mathrm{a}$ & $\mathrm{n} / \mathrm{a}$ & $\mathrm{n} / \mathrm{a}$ & $\mathrm{n} / \mathrm{a}$ & $\mathrm{n} / \mathrm{a}$ & $\mathrm{n} / \mathrm{a}$ & $\mathrm{n} / \mathrm{a}$ \\
\hline & & & Frequency & 0.0000 & 0.0000 & 0.0000 & 0.0000 & $\mathrm{n} / \mathrm{a}$ & $\mathrm{n} / \mathrm{a}$ & $\mathrm{n} / \mathrm{a}$ & $\mathrm{n} / \mathrm{a}$ \\
\hline & & Fall & Density & $\mathrm{n} / \mathrm{a}$ & $\mathrm{n} / \mathrm{a}$ & $\mathrm{n} / \mathrm{a}$ & $\mathrm{n} / \mathrm{a}$ & $\mathrm{n} / \mathrm{a}$ & $\mathrm{n} / \mathrm{a}$ & $\mathrm{n} / \mathrm{a}$ & $\mathrm{n} / \mathrm{a}$ \\
\hline & & & Frequency & 0.0000 & 0.0000 & 0.0000 & 0.0000 & $\mathrm{n} / \mathrm{a}$ & $\mathrm{n} / \mathrm{a}$ & $\mathrm{n} / \mathrm{a}$ & $\mathrm{n} / \mathrm{a}$ \\
\hline & & Winter & Density & $\mathrm{n} / \mathrm{a}$ & $\mathrm{n} / \mathrm{a}$ & $\mathrm{n} / \mathrm{a}$ & $\mathrm{n} / \mathrm{a}$ & $\mathrm{n} / \mathrm{a}$ & $\mathrm{n} / \mathrm{a}$ & $\mathrm{n} / \mathrm{a}$ & $\mathrm{n} / \mathrm{a}$ \\
\hline & & & Frequency & 0.0000 & 0.0000 & 0.8258 & 0.6875 & $\mathrm{n} / \mathrm{a}$ & $\mathrm{n} / \mathrm{a}$ & $\mathrm{n} / \mathrm{a}$ & $\mathrm{n} / \mathrm{a}$ \\
\hline & & Total & Density & $\mathrm{n} / \mathrm{a}$ & $\mathrm{n} / \mathrm{a}$ & $\mathrm{n} / \mathrm{a}$ & $\mathrm{n} / \mathrm{a}$ & $\mathrm{n} / \mathrm{a}$ & $\mathrm{n} / \mathrm{a}$ & $\mathrm{n} / \mathrm{a}$ & $\mathrm{n} / \mathrm{a}$ \\
\hline & & & Frequency & 0.0000 & 0.0000 & 0.2040 & 0.1094 & $\mathrm{n} / \mathrm{a}$ & $\mathrm{n} / \mathrm{a}$ & $\mathrm{n} / \mathrm{a}$ & $\mathrm{n} / \mathrm{a}$ \\
\hline \multirow[t]{10}{*}{ Lophodytes cucullatus } & Hooded merganser & Spring & Density & 0.0246 & 0.0147 & 0.0029 & 0.0029 & 0.0086 & 0.0045 & 0.0189 & 0.0145 \\
\hline & & & Frequency & 0.1157 & 0.0530 & 0.0227 & 0.0227 & 0.0570 & 0.0030 & 0.0814 & 0.0504 \\
\hline & & Summer & Density & 0.0000 & 0.0000 & 0.0007 & 0.0007 & 0.0000 & 0.0000 & 0.0007 & 0.0007 \\
\hline & & & Frequency & 0.0000 & 0.0000 & 0.0083 & 0.0083 & 0.0000 & 0.0000 & 0.0083 & 0.0083 \\
\hline & & Fall & Density & 0.0045 & 0.0045 & 0.0000 & 0.0000 & 0.0000 & 0.0000 & 0.0045 & 0.0045 \\
\hline & & & Frequency & 0.0531 & 0.0531 & 0.0000 & 0.0000 & 0.0000 & 0.0000 & 0.0531 & 0.0531 \\
\hline & & Winter & Density & 0.0000 & 0.0000 & 0.0000 & 0.0000 & 0.0000 & 0.0000 & 0.0000 & 0.0000 \\
\hline & & & Frequency & 0.0000 & 0.0000 & 0.0000 & 0.0000 & 0.0000 & 0.0000 & 0.0000 & 0.0000 \\
\hline & & Total & Density & 0.0083 & 0.0044 & 0.0010 & 0.0009 & 0.0025 & 0.0013 & 0.0069 & 0.0043 \\
\hline & & & Frequency & 0.0482 & 0.0216 & 0.0089 & 0.0069 & 0.0163 & 0.0087 & 0.0408 & 0.0210 \\
\hline \multirow[t]{2}{*}{ Mergus serrator } & Red-breasted merganser & Spring & Density & 0.0000 & 0.0000 & 0.0234 & 0.0234 & 0.0234 & 0.0234 & 0.0000 & 0.0000 \\
\hline & & & Frequency & 0.0000 & 0.0000 & 0.1393 & 0.1393 & 0.1393 & 0.1393 & 0.0000 & 0.0000 \\
\hline
\end{tabular}


Appendix I. Continued.

\begin{tabular}{|c|c|c|c|c|c|c|c|c|c|c|c|}
\hline \multirow[b]{3}{*}{ Scientific name } & \multirow[b]{3}{*}{ Common name } & \multirow[b]{3}{*}{ Season $^{\mathrm{b}}$} & \multirow[b]{3}{*}{ Measure } & \multicolumn{4}{|c|}{ Channel } & \multicolumn{4}{|c|}{ Side } \\
\hline & & & & \multicolumn{2}{|c|}{ Back } & \multicolumn{2}{|c|}{ Main } & \multicolumn{2}{|c|}{ Island } & \multicolumn{2}{|c|}{ Mainland } \\
\hline & & & & $\bar{x}$ & $\mathrm{SE}$ & $x$ & $\mathrm{SE}$ & $\bar{x}$ & $\mathrm{SE}$ & $\bar{x}$ & $\mathrm{SE}$ \\
\hline & & Summer & Density & 0.0000 & 0.0000 & 0.0000 & 0.0000 & 0.0000 & 0.0000 & 0.0000 & 0.0000 \\
\hline & & & Frequency & 0.0000 & 0.0000 & 0.0000 & 0.0000 & 0.0000 & 0.0000 & 0.0000 & 0.0000 \\
\hline & & Fall & Density & 0.0126 & 0.0098 & 0.0000 & 0.0000 & 0.0094 & 0.0094 & 0.0032 & 0.0032 \\
\hline & & & Frequency & 0.0269 & 0.0211 & 0.0000 & 0.0000 & 0.0202 & 0.0202 & 0.0067 & 0.0067 \\
\hline & & Winter & Density & 0.0000 & 0.0000 & 0.0000 & 0.0000 & 0.0000 & 0.0000 & 0.0000 & 0.0000 \\
\hline & & & Frequency & 0.0000 & 0.0000 & 0.0000 & 0.0000 & 0.0000 & 0.0000 & 0.0000 & 0.0000 \\
\hline & & Total & Density & 0.0036 & 0.0028 & 0.0067 & 0.0067 & 0.0094 & 0.0072 & 0.0009 & 0.0009 \\
\hline & & & Frequency & 0.0077 & 0.0061 & 0.0398 & 0.0398 & 0.0456 & 0.0402 & 0.0019 & 0.0019 \\
\hline \multirow[t]{10}{*}{ Phalacrocorax auritus } & Double-crested cormorant & Spring & Density & 0.0043 & 0.0030 & 0.0823 & 0.0507 & 0.0382 & 0.0286 & 0.0484 & 0.0429 \\
\hline & & & Frequency & 0.0425 & 0.0328 & 0.2854 & 0.1691 & 0.1270 & 0.0663 & 0.2009 & 0.1612 \\
\hline & & Summer & Density & 0.0054 & 0.0036 & 0.0081 & 0.0048 & 0.0051 & 0.0034 & 0.0084 & 0.0050 \\
\hline & & & Frequency & 0.0458 & 0.0256 & 0.0447 & 0.0259 & 0.0284 & 0.0138 & 0.0621 & 0.0335 \\
\hline & & Fall & Density & 0.0033 & 0.0033 & 0.0113 & 0.0107 & 0.0146 & 0.0111 & 0.0000 & 0.0000 \\
\hline & & & Frequency & 0.0144 & 0.0144 & 0.0364 & 0.0311 & 0.0508 & 0.0339 & 0.0000 & 0.0000 \\
\hline & & Winter & Density & 0.0000 & 0.0000 & 0.0000 & 0.0000 & 0.0000 & 0.0000 & 0.0000 & 0.0000 \\
\hline & & & Frequency & 0.0000 & 0.0000 & 0.0000 & 0.0000 & 0.0000 & 0.0000 & 0.0000 & 0.0000 \\
\hline & & Total & Density & 0.0037 & 0.0016 & 0.0291 & 0.0150 & 0.0166 & 0.0088 & 0.0162 & 0.0124 \\
\hline & & & Frequency & 0.0294 & 0.0126 & 0.1047 & 0.0502 & 0.0589 & 0.0218 & 0.0751 & 0.0471 \\
\hline \multirow[t]{6}{*}{ Podiceps auritus } & Horned grebe & Spring & Density & 0.0038 & 0.0032 & 0.0000 & 0.0000 & 0.0000 & 0.0000 & 0.0038 & 0.0032 \\
\hline & & & Frequency & 0.0143 & 0.0100 & 0.0000 & 0.0000 & 0.0000 & 0.0000 & 0.0143 & 0.0100 \\
\hline & & Summer & Density & 0.0000 & 0.0000 & 0.0000 & 0.0000 & 0.0000 & 0.0000 & 0.0000 & 0.0000 \\
\hline & & & Frequency & 0.0000 & 0.0000 & 0.0000 & 0.0000 & 0.0000 & 0.0000 & 0.0000 & 0.0000 \\
\hline & & Fall & Density & 0.0000 & 0.0000 & 0.0000 & 0.0000 & 0.0000 & 0.0000 & 0.0000 & 0.0000 \\
\hline & & & Frequency & 0.0000 & 0.0000 & 0.0000 & 0.0000 & 0.0000 & 0.0000 & 0.0000 & 0.0000 \\
\hline
\end{tabular}


Appendix I. Continued.

\begin{tabular}{|c|c|c|c|c|c|c|c|c|c|c|c|}
\hline \multirow[b]{3}{*}{ Scientific name } & \multirow[b]{3}{*}{ Common name } & \multirow[b]{3}{*}{ Season $^{\mathrm{b}}$} & \multirow[b]{3}{*}{ Measure } & \multicolumn{4}{|c|}{ Channel } & \multicolumn{4}{|c|}{ Side } \\
\hline & & & & \multicolumn{2}{|c|}{ Back } & \multicolumn{2}{|c|}{ Main } & \multicolumn{2}{|c|}{ Island } & \multicolumn{2}{|c|}{ Mainland } \\
\hline & & & & $\bar{x}$ & SE & $x$ & $\mathrm{SE}$ & $\bar{x}$ & $\mathrm{SE}$ & $x$ & $\mathrm{SE}$ \\
\hline & & Winter & Density & 0.0000 & 0.0000 & 0.0000 & 0.0000 & 0.0000 & 0.0000 & 0.0000 & 0.0000 \\
\hline & & & Frequency & 0.0000 & 0.0000 & 0.0000 & 0.0000 & 0.0000 & 0.0000 & 0.0000 & 0.0000 \\
\hline & & Total & Density & 0.0011 & 0.0009 & 0.0000 & 0.0000 & 0.0000 & 0.0000 & 0.0011 & 0.0009 \\
\hline & & & Frequency & 0.0041 & 0.0029 & 0.0000 & 0.0000 & 0.0000 & 0.0000 & 0.0041 & 0.0029 \\
\hline \multirow[t]{10}{*}{ Podilymbus podiceps } & Pied-billed grebe & Spring & Density & 0.0254 & 0.0118 & 0.0097 & 0.0052 & 0.0146 & 0.0075 & 0.0206 & 0.0106 \\
\hline & & & Frequency & 0.0908 & 0.0388 & 0.0542 & 0.0298 & 0.0540 & 0.0238 & 0.0910 & 0.0427 \\
\hline & & Summer & Density & 0.0000 & 0.0000 & 0.0107 & 0.0107 & 0.0107 & 0.0107 & 0.0000 & 0.0000 \\
\hline & & & Frequency & 0.0000 & 0.0000 & 0.0307 & 0.0307 & 0.0307 & 0.0307 & 0.0000 & 0.0000 \\
\hline & & Fall & Density & 0.0038 & 0.0038 & 0.0000 & 0.0000 & 0.0000 & 0.0000 & 0.0038 & 0.0038 \\
\hline & & & Frequency & 0.0143 & 0.0143 & 0.0000 & 0.0000 & 0.0000 & 0.0000 & 0.0143 & 0.0143 \\
\hline & & Winter & Density & 0.1124 & 0.1086 & 0.0071 & 0.0071 & 0.0000 & 0.0000 & 0.1196 & 0.1084 \\
\hline & & & Frequency & 0.1830 & 0.1591 & 0.0260 & 0.0260 & 0.0000 & 0.0000 & 0.2090 & 0.1596 \\
\hline & & Total & Density & 0.0244 & 0.0159 & 0.0069 & 0.0035 & 0.0072 & 0.0037 & 0.0240 & 0.0158 \\
\hline & & & Frequency & 0.0562 & 0.0257 & 0.0280 & 0.0128 & 0.0242 & 0.0112 & 0.0599 & 0.0264 \\
\hline \multirow[t]{10}{*}{ Sterna hirundo } & Common tern & Spring & Density & 0.0000 & 0.0000 & 0.0000 & 0.0000 & 0.0000 & 0.0000 & 0.0000 & 0.0000 \\
\hline & & & Frequency & 0.0000 & 0.0000 & 0.0000 & 0.0000 & 0.0000 & 0.0000 & 0.0000 & 0.0000 \\
\hline & & Summer & Density & 0.0000 & 0.0000 & 0.0000 & 0.0000 & 0.0000 & 0.0000 & 0.0000 & 0.0000 \\
\hline & & & Frequency & 0.0000 & 0.0000 & 0.0000 & 0.0000 & 0.0000 & 0.0000 & 0.0000 & 0.0000 \\
\hline & & Fall & Density & 0.0006 & 0.0006 & 0.0000 & 0.0000 & 0.0000 & 0.0000 & 0.0006 & 0.0006 \\
\hline & & & Frequency & 0.0061 & 0.0061 & 0.0000 & 0.0000 & 0.0000 & 0.0000 & 0.0061 & 0.0061 \\
\hline & & Winter & Density & 0.0000 & 0.0000 & 0.0000 & 0.0000 & 0.0000 & 0.0000 & 0.0000 & 0.0000 \\
\hline & & & Frequency & 0.0000 & 0.0000 & 0.0000 & 0.0000 & 0.0000 & 0.0000 & 0.0000 & 0.0000 \\
\hline & & Total & Density & 0.0002 & 0.0002 & 0.0000 & 0.0000 & 0.0000 & 0.0000 & 0.0002 & 0.0002 \\
\hline & & & Frequency & 0.0017 & 0.0017 & 0.0000 & 0.0000 & 0.0000 & 0.0000 & 0.0017 & 0.0017 \\
\hline
\end{tabular}


Appendix I. Continued.

\begin{tabular}{|c|c|c|c|c|c|c|c|c|c|c|c|}
\hline \multirow[b]{3}{*}{ Scientific name } & \multirow[b]{3}{*}{ Common name } & \multirow[b]{3}{*}{ Season $^{\mathrm{b}}$} & \multirow[b]{3}{*}{ Measure } & \multicolumn{4}{|c|}{ Channel } & \multicolumn{4}{|c|}{ Side } \\
\hline & & & & \multicolumn{2}{|c|}{ Back } & \multicolumn{2}{|c|}{ Main } & \multicolumn{2}{|c|}{ Island } & \multicolumn{2}{|c|}{ Mainland } \\
\hline & & & & $\bar{x}$ & SE & $\bar{x}$ & SE & $\bar{x}$ & SE & $\bar{x}$ & $\mathrm{SE}$ \\
\hline \multirow[t]{10}{*}{ Tringa solitaria } & Solitary sandpiper & Spring & Density & 0.0000 & 0.0000 & 0.0000 & 0.0000 & 0.0000 & 0.0000 & 0.0000 & 0.0000 \\
\hline & & & Frequency & 0.0000 & 0.0000 & 0.0000 & 0.0000 & 0.0000 & 0.0000 & 0.0000 & 0.0000 \\
\hline & & Summer & Density & 0.0000 & 0.0000 & 0.0000 & 0.0000 & 0.0000 & 0.0000 & 0.0000 & 0.0000 \\
\hline & & & Frequency & 0.0000 & 0.0000 & 0.0000 & 0.0000 & 0.0000 & 0.0000 & 0.0000 & 0.0000 \\
\hline & & Fall & Density & 0.0000 & 0.0000 & 0.0562 & 0.0562 & 0.0562 & 0.0562 & 0.0000 & 0.0000 \\
\hline & & & Frequency & 0.0000 & 0.0000 & 0.0781 & 0.0781 & 0.0781 & 0.0781 & 0.0000 & 0.0000 \\
\hline & & Winter & Density & 0.0000 & 0.0000 & 0.0000 & 0.0000 & 0.0000 & 0.0000 & 0.0000 & 0.0000 \\
\hline & & & Frequency & 0.0000 & 0.0000 & 0.0000 & 0.0000 & 0.0000 & 0.0000 & 0.0000 & 0.0000 \\
\hline & & Total & Density & 0.0000 & 0.0000 & 0.0160 & 0.0160 & 0.0160 & 0.0160 & 0.0000 & 0.0000 \\
\hline & & & Frequency & 0.0000 & 0.0000 & 0.0223 & 0.0223 & 0.0223 & 0.0223 & 0.0000 & 0.0000 \\
\hline
\end{tabular}

${ }^{a}$ Back channel: back channel-island side and back channel-mainland side treatments; main channel: main channel-island side and main channel-mainland side treatments. Island side: back channel-island side and main channel-island side treatments; mainland side: back channel-mainland side and main channel-mainland side treatments. Each treatment encompassed the length of the associated island and one-half the width of the associated back channel.

${ }^{b}$ Spring: 21 March-7 April 2001, 23-25 March 2002; summer: 14-28 May, 11-27 June 2002, 16-25 May, 17-26 June, 17 July-13 August 2002; fall: 10-16 November 2001, 28 September-6 October 2002; winter: 26-28 January 2002.

${ }^{c}$ Observed farther from the main channel shorelines than the treatments encompassed; therefore density was not determined and effects involving sides were not tested for.

${ }^{\mathrm{d}}$ Including individuals occurring farther from the main channel shorelines than the treatments encompassed; therefore density was not determined and effects involving sides were not tested for. 
Appendix J. Relative abundance (no. captured/trap-night) of all turtles, snapping turtles and spiny softshells encountered on island and mainland sides associated with 10 islands on the Ohio River, West Virginia, USA, 2001-2002.

\begin{tabular}{|c|c|c|c|c|c|c|}
\hline \multirow[b]{3}{*}{ Variable } & \multicolumn{4}{|c|}{ Side $^{\mathrm{a}}$} & \multirow[b]{3}{*}{$F_{1,27}$} & \multirow[b]{3}{*}{$P$} \\
\hline & \multicolumn{2}{|c|}{ Island } & \multicolumn{2}{|c|}{ Mainland } & & \\
\hline & $\bar{x}$ & SE & $\bar{x}$ & SE & & \\
\hline All turtles ${ }^{\mathrm{b}}$ & 0.22 & 0.04 & 0.21 & 0.03 & 0.12 & 0.731 \\
\hline Spiny softshell & 0.08 & 0.03 & 0.09 & 0.03 & 0.06 & 0.811 \\
\hline Snapping turtle & 0.10 & 0.03 & 0.08 & 0.03 & 1.18 & 0.286 \\
\hline
\end{tabular}

${ }^{a}$ Island side: back channel-island side and main channel-island side treatments; mainland side: back channel-mainland side and main channel-mainland side treatments. Each treatment encompassed the length of the associated island and one-half the width of the associated back channel.

${ }^{\mathrm{b}}$ All turtles included painted turtles, smooth softshells, snapping turtles, spiny softshells, and stinkpots. 
Appendix K. Relative abundance (frequency of transects containing sign or direct observations) of beavers and muskrat encountered on island and mainland sides associated with 10 islands on the Ohio River, West Virginia, USA, 2001-2002.

\begin{tabular}{|c|c|c|c|c|c|c|}
\hline \multirow[b]{3}{*}{ Species } & \multicolumn{4}{|c|}{$\operatorname{Side}^{\mathrm{a}}$} & \multirow[b]{3}{*}{$F_{1,27}$} & \multirow[b]{3}{*}{$P$} \\
\hline & \multicolumn{2}{|c|}{ Island } & \multicolumn{2}{|c|}{ Mainland } & & \\
\hline & $\bar{x}$ & SE & $\bar{x}$ & SE & & \\
\hline Beaver & 0.74 & 0.05 & 0.61 & 0.06 & 4.19 & 0.051 \\
\hline Muskrat & 0.50 & 0.08 & 0.38 & 0.07 & 2.94 & 0.098 \\
\hline
\end{tabular}

${ }^{a}$ Island side: back channel-island side and main channel-island side treatments; mainland side: back channel-mainland side and main channel-mainland side treatments. Each treatment encompassed the length of the associated island and one-half the width of the associated back channel. 
Appendix L. Tests for channel, side, and treatment interactions with year, season, and/or period for measures of relative abundance of waterbirds, waterfowl, wading birds, 5 waterbird species, turtles, 2 turtle species, and waterbird richness (no. species) and diversity (Shannon \& Weaver 1949), associated with 10 islands on the Ohio River, West Virginia, USA, 2001-2002. ${ }^{\text {a }}$

\begin{tabular}{|c|c|c|c|c|c|}
\hline Species & Variable $^{\mathrm{b}}$ & Source ${ }^{c}$ & $F$ & $\mathrm{df}$ & $P$ \\
\hline \multirow[t]{24}{*}{ All waterbirds ${ }^{d}$} & \multirow[t]{6}{*}{ Density } & Channel $\times$ year & 2.83 & 1,36 & 0.101 \\
\hline & & Side $\times$ year & 0.30 & 1,36 & 0.585 \\
\hline & & Treatment $\times$ year & 1.04 & 3,36 & 0.385 \\
\hline & & Channel $\times$ season & 1.47 & 3,180 & 0.223 \\
\hline & & Side $\times$ season & 3.00 & 3,180 & $\mathbf{0 . 0 3 2}$ \\
\hline & & Treatment $\times$ season & 1.53 & 9,180 & 0.142 \\
\hline & \multirow[t]{6}{*}{ Frequency } & Channel $\times$ year & 2.81 & 1,36 & 0.102 \\
\hline & & Side $\times$ year & 0.67 & 1,36 & 0.419 \\
\hline & & Treatment $\times$ year & 1.16 & 3,36 & 0.338 \\
\hline & & Channel $\times$ season & 1.81 & 3,180 & 0.147 \\
\hline & & Side $\times$ season & 3.03 & 3,180 & $\mathbf{0 . 0 3 1}$ \\
\hline & & Treatment $\times$ season & 1.63 & 9,180 & 0.111 \\
\hline & \multirow[t]{6}{*}{ Richness } & Channel $\times$ year & 2.20 & 1,36 & 0.147 \\
\hline & & Side $\times$ year & 1.36 & 1,36 & 0.252 \\
\hline & & Treatment $\times$ year & 1.22 & 3,36 & 0.317 \\
\hline & & Channel $\times$ season & 2.22 & 3,180 & 0.088 \\
\hline & & Side $\times$ season & 2.64 & 3,180 & 0.051 \\
\hline & & Treatment $\times$ season & 2.31 & 9,180 & 0.018 \\
\hline & \multirow[t]{6}{*}{ Diversity } & Channel $\times$ year & 1.56 & 1,36 & 0.220 \\
\hline & & Side $\times$ year & 0.18 & 1,36 & 0.672 \\
\hline & & Treatment $\times$ year & 0.61 & 3,36 & 0.610 \\
\hline & & Channel $\times$ season & 1.93 & 3,180 & 0.126 \\
\hline & & Side $\times$ season & 0.79 & 3,180 & 0.502 \\
\hline & & Treatment $\times$ season & 1.90 & 9,180 & 0.055 \\
\hline \multirow[t]{10}{*}{ Waterfowl $\mathrm{l}^{\mathrm{e}}$} & \multirow[t]{6}{*}{ Density } & Channel $\times$ year & 1.05 & 1,36 & 0.313 \\
\hline & & Side $\times$ year & 1.44 & 1,36 & 0.238 \\
\hline & & Treatment $\times$ year & 0.90 & 3,36 & 0.450 \\
\hline & & Channel $\times$ season & 2.09 & 3,180 & 0.103 \\
\hline & & Side $\times$ season & 1.36 & 3,180 & 0.257 \\
\hline & & Treatment $\times$ season & 1.53 & 9,180 & 0.139 \\
\hline & \multirow[t]{4}{*}{ Frequency } & Channel $\times$ year & 1.25 & 1,36 & 0.271 \\
\hline & & Side $\times$ year & 2.24 & 1,36 & 0.143 \\
\hline & & Treatment $\times$ year & 1.27 & 3,36 & 0.298 \\
\hline & & Channel $\times$ season & 2.59 & 3,180 & 0.054 \\
\hline
\end{tabular}


Appendix L. Continued.

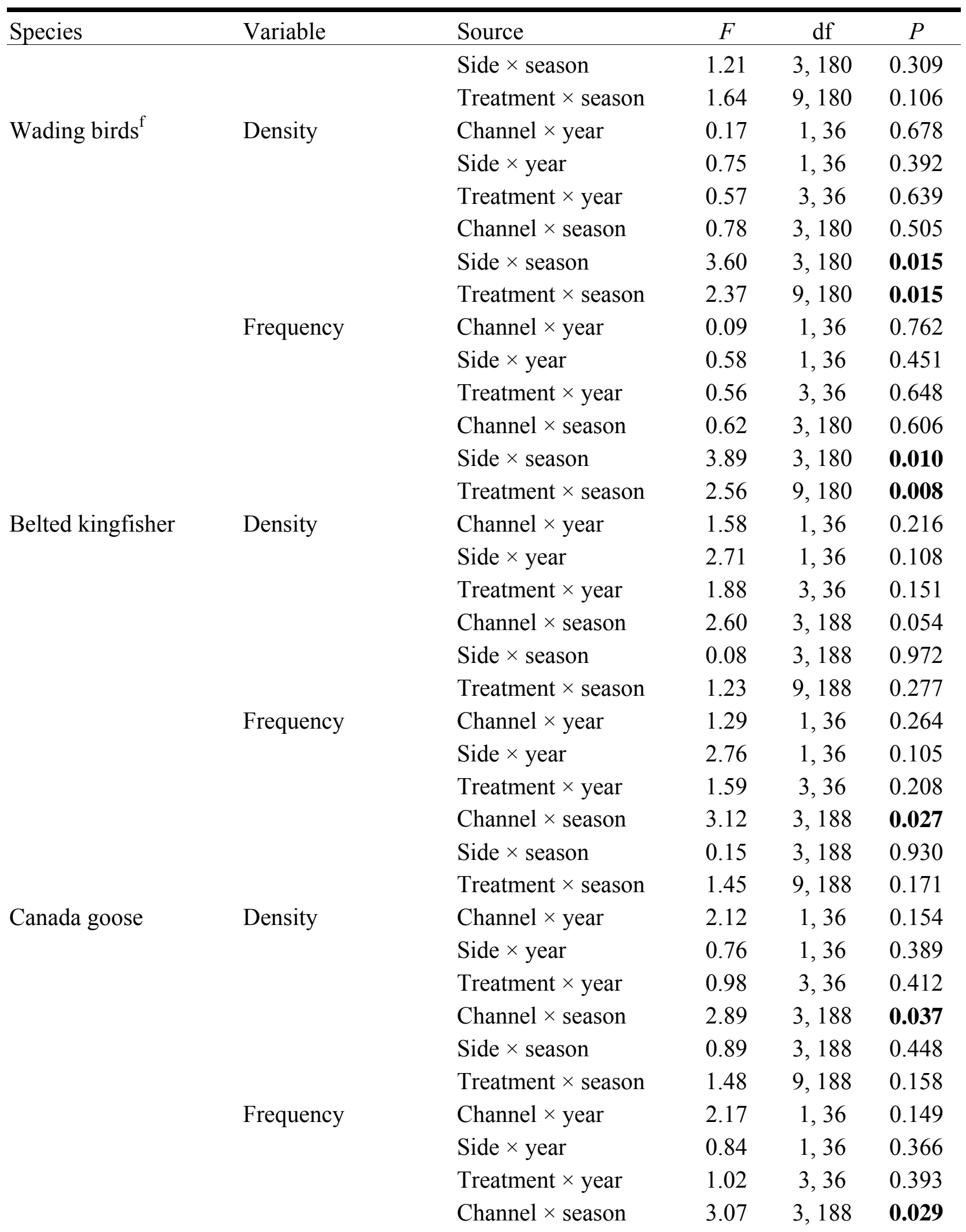


Appendix L. Continued.

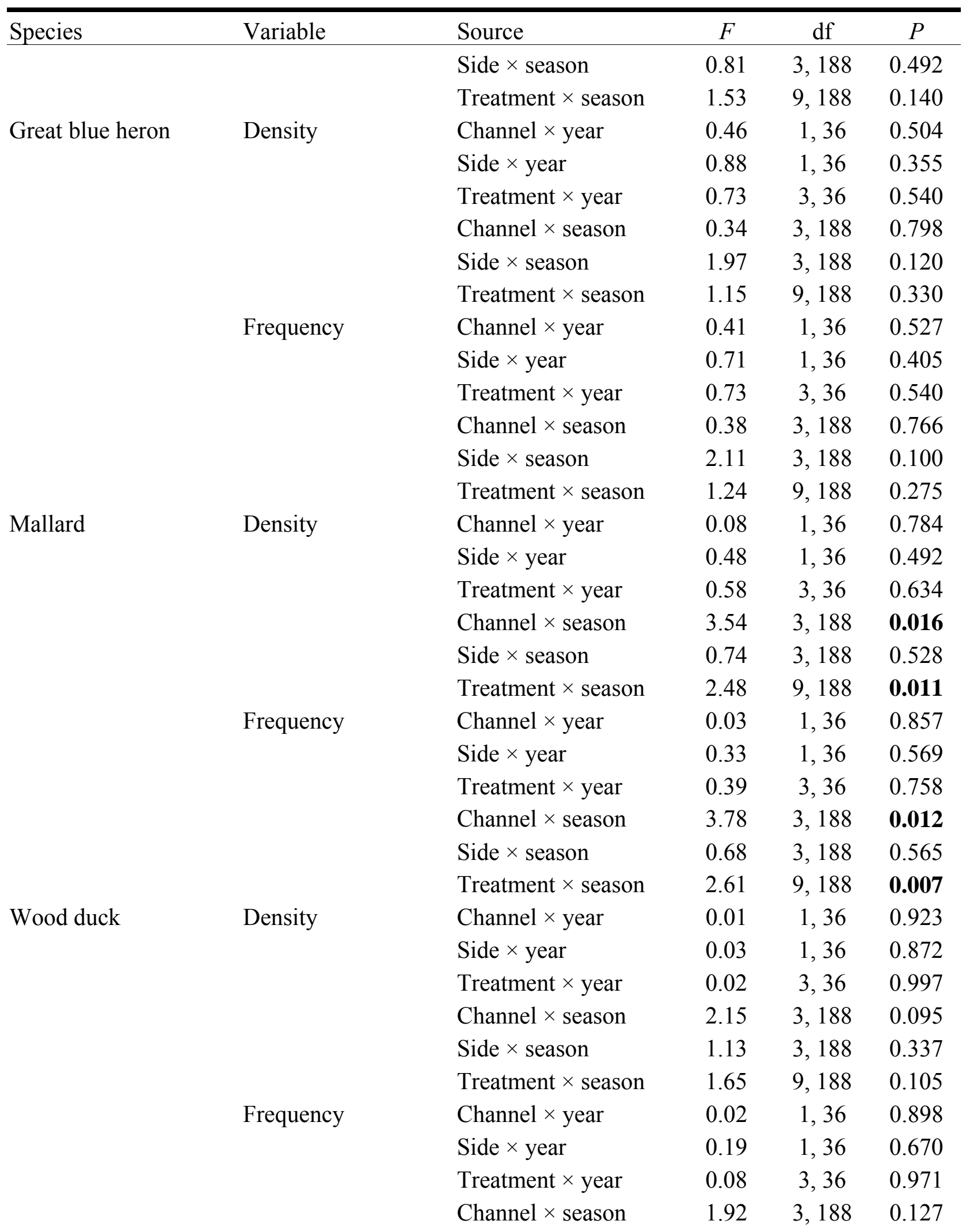


Appendix L. Continued.

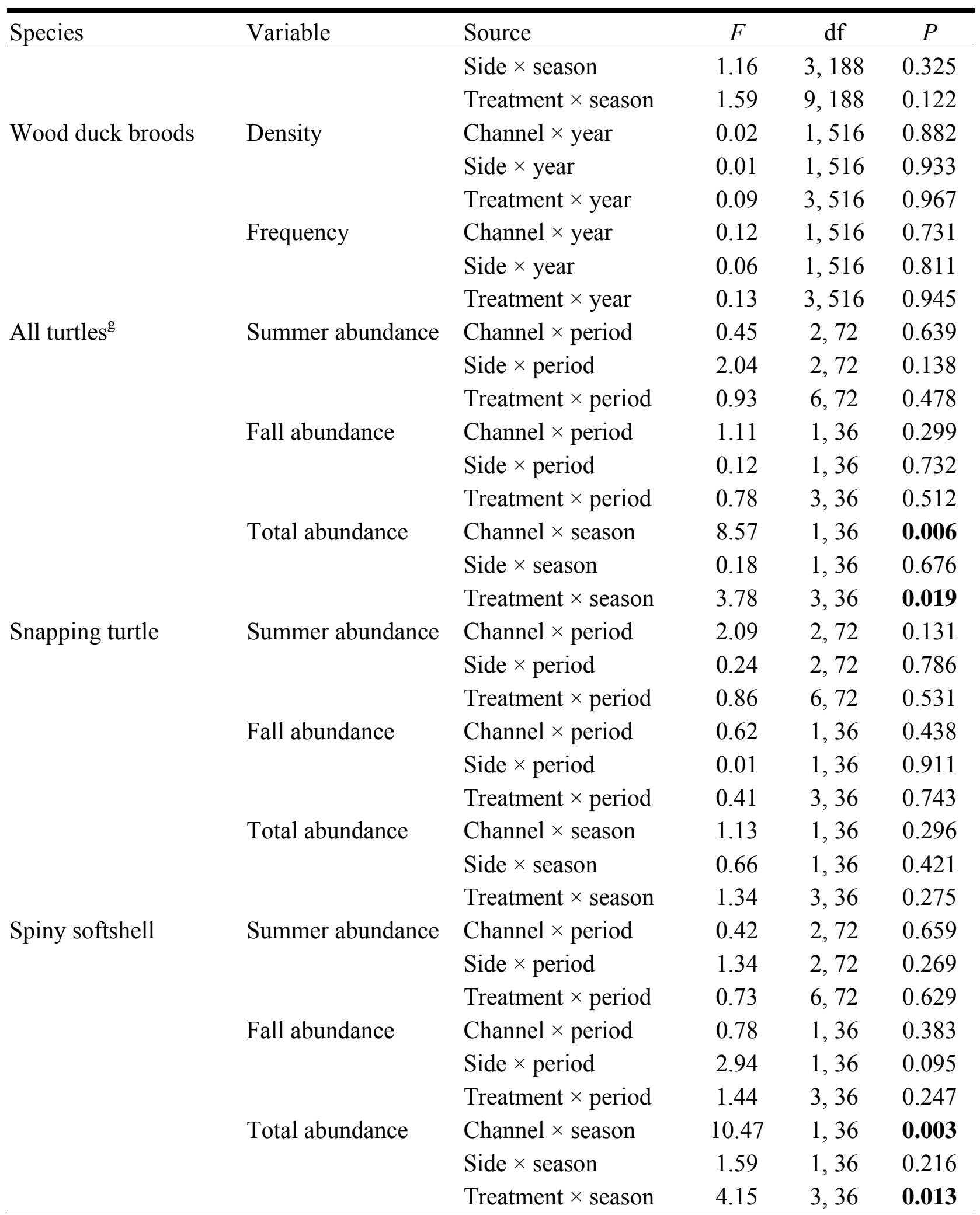


Appendix L. Continued.

${ }^{a}$ Back channel: back channel-island side and back channel-mainland side treatments; main channel: main channel-island side and main channel-mainland side treatments. Island side: back channel-island side and main channel-island side treatments; mainland side: back channelmainland side and main channel-mainland side treatments. Each treatment encompassed the length of the associated island and one-half the width of the associated back channel.

${ }^{\mathrm{b}}$ Density: no./ha; Frequency: no./km; turtle relative abundance: no. captured/trap-night

${ }^{\mathrm{c}}$ Waterbirds were surveyed during the following seasons and years: Spring: 21 March-7 April 2001, 23-25 March 2002; summer: 14-28 May, 11-27 June 2002, 16-25 May, 17-26 June, 17 July-13 August 2002; fall: 10-16 November 2001, 28 September-6 October 2002; winter: 26-28 January 2002. Turtles were surveyed during 3 summer periods and 2 fall periods. Summer: 1123 June, 12 July-13 August, 26 July-14 August 2002; fall: 23 September-14 October 2001, 5-14 October 2002.

${ }^{\mathrm{d}}$ Divers, grebes, cormorants, waterfowl, herons, coots, gulls and terns, sandpipers and associates, and belted kingfishers

${ }^{\mathrm{e}}$ Ducks and geese

${ }^{\mathrm{f}}$ Herons, sandpipers, and killdeer

${ }^{\mathrm{g}}$ All turtles include painted turtles, smooth softshells, snapping turtles, spiny softshells, and stinkpots. 
Appendix M. Tests for channel interactions with year, season, and/or period for frequency (no. birds $/ \mathrm{km}$ ) of waterbirds, waterfowl, and wading birds, waterbird richness (no. species/channel) and waterbird diversity (Shannon \& Weaver 1949), including those individuals occurring farther from main channel shorelines than half the width of the associated back channel, associated with 10 islands on the Ohio River, West Virginia, USA, 2001-2002. ${ }^{a}$

\begin{tabular}{|c|c|c|c|c|c|}
\hline Species & Variable & Source ${ }^{b}$ & $F$ & $\mathrm{df}$ & $P$ \\
\hline \multirow[t]{6}{*}{ All waterbirds ${ }^{c}$} & \multirow[t]{2}{*}{ Frequency } & Channel $\times$ year & 2.29 & 1,36 & 0.139 \\
\hline & & Channel $\times$ season & 0.96 & 3,180 & 0.414 \\
\hline & \multirow[t]{2}{*}{ Richness } & Channel $\times$ year & 2.34 & 1,36 & 0.135 \\
\hline & & Channel $\times$ season & 1.81 & 3,180 & 0.146 \\
\hline & \multirow{2}{*}{ Diversity } & Channel $\times$ year & 1.64 & 1,36 & 0.208 \\
\hline & & Channel $\times$ season & 1.69 & 3,180 & 0.170 \\
\hline \multirow[t]{2}{*}{ Waterfowl $^{\mathrm{d}}$} & \multirow[t]{2}{*}{ Frequency } & Channel $\times$ year & 1.35 & 1,36 & 0.253 \\
\hline & & Channel $\times$ season & 3.10 & 3,180 & 0.028 \\
\hline \multirow[t]{2}{*}{ Wading birds ${ }^{\mathrm{e}}$} & \multirow[t]{2}{*}{ Frequency } & Channel $\times$ year & 0.09 & 1,36 & 0.769 \\
\hline & & Channel $\times$ season & 0.74 & 3,180 & 0.529 \\
\hline
\end{tabular}

${ }^{a}$ Back channel: back channel-island side and back channel-mainland side treatments; main channel: main channel-island side and main channel-mainland side treatments. Each treatment encompassed the length of the associated island and one-half the width of the associated back channel.

${ }^{\mathrm{b}}$ Waterbirds were surveyed during the following seasons and years: Spring: 21 March-7 April 2001, 23-25 March 2002; summer: 14-28 May, 11-27 June 2002, 16-25 May, 17-26 June, 17 July-13 August 2002; fall: 10-16 November 2001, 28 September-6 October 2002; winter: 26-28 January 2002.

${ }^{\mathrm{c}}$ Divers, grebes, cormorants, waterfowl, herons, coots, gulls and terns, sandpipers and associates, and belted kingfishers

${ }^{\mathrm{d}}$ Ducks and geese

${ }^{\mathrm{e}}$ Herons, sandpipers, and killdeer 
Appendix N. Variables (V) measured and equations used to determine life components (based on suitability indices [SI]), and habitat suitability index (HSI) scores for belted kingfisher (Prose 1985), great blue heron (Short and Cooper 1985), mink (Allen 1984), muskrat (Allen and Hoffman 1984), snapping turtle (Graves and Anderson 1987), and wood duck (Sousa and Farmer 1983) models, on treatments, channels, and sides, associated with 10 islands on the Ohio River, West Virginia, 2001-2002. ${ }^{\text {a }}$

\begin{tabular}{|c|c|c|c|c|c|c|c|c|c|c|c|c|c|c|c|c|}
\hline \multirow[b]{3}{*}{ HSI model and variables } & \multicolumn{8}{|c|}{ Treatment } & \multicolumn{4}{|c|}{ Channel } & \multicolumn{4}{|c|}{ Side } \\
\hline & \multicolumn{2}{|c|}{$\mathrm{BI}$} & \multicolumn{2}{|c|}{$\mathrm{BM}$} & \multicolumn{2}{|c|}{ M I } & \multicolumn{2}{|c|}{ MM } & \multicolumn{2}{|c|}{ Back } & \multicolumn{2}{|c|}{ Main } & \multicolumn{2}{|c|}{ Island } & \multicolumn{2}{|c|}{ Mainland } \\
\hline & $\bar{x}$ & SE & $\bar{x}$ & SE & $\bar{x}$ & $\mathrm{SE}$ & $\bar{x}$ & $\mathrm{SE}$ & $\bar{x}$ & SE & $\bar{x}$ & SE & $\bar{x}$ & $\mathrm{SE}$ & $\bar{x}$ & SE \\
\hline \multicolumn{17}{|l|}{ Belted kingfisher HSI } \\
\hline \multicolumn{17}{|l|}{ V2: water transparency $(\mathrm{m})$} \\
\hline$\leq 15 \mathrm{~m}$ from shore & 0.93 & 0.15 & 0.83 & 0.12 & 1.04 & 0.11 & 0.94 & 0.10 & 0.88 & 0.09 & 0.99 & 0.07 & 0.99 & 0.09 & 0.88 & 0.08 \\
\hline SIV2 & 0.89 & 0.07 & 0.89 & 0.07 & 1.00 & 0.00 & 0.99 & 0.01 & 0.89 & 0.05 & 0.99 & 0.01 & 0.94 & 0.04 & 0.94 & 0.04 \\
\hline \multicolumn{17}{|l|}{ V3: \% surface obstruction } \\
\hline$\leq 15 \mathrm{~m}$ from shore & 16.63 & 2.11 & 13.57 & 2.07 & 3.17 & 0.70 & 1.96 & 0.51 & 15.10 & 1.48 & 2.57 & 0.44 & 9.90 & 2.04 & 7.77 & 1.82 \\
\hline SIV3 & 0.84 & 0.02 & 0.87 & 0.02 & 0.97 & 0.01 & 0.98 & 0.00 & 0.85 & 0.01 & 0.97 & 0.00 & 0.90 & 0.02 & 0.92 & 0.02 \\
\hline \multicolumn{17}{|l|}{ V4: \% water area $<60 \mathrm{~cm}$} \\
\hline$\leq 15 \mathrm{~m}$ from shore & 16.30 & 1.88 & 13.84 & 1.60 & 24.65 & 4.12 & 28.00 & 6.20 & 15.07 & 1.23 & 26.33 & 3.62 & 20.48 & 2.44 & 20.92 & 3.59 \\
\hline SIV4 & 0.37 & 0.01 & 0.35 & 0.01 & 0.45 & 0.02 & 0.48 & 0.04 & 0.36 & 0.01 & 0.46 & 0.02 & 0.41 & 0.02 & 0.42 & 0.02 \\
\hline V5: \% riffles & 0.00 & 0.00 & 0.00 & 0.00 & 0.00 & 0.00 & 0.06 & 0.06 & 0.00 & 0.00 & 0.03 & 0.03 & 0.00 & 0.00 & 0.03 & 0.03 \\
\hline SIV5 & 0.20 & 0.00 & 0.20 & 0.00 & 0.20 & 0.00 & 0.20 & 0.00 & 0.20 & 0.00 & 0.20 & 0.00 & 0.20 & 0.00 & 0.20 & 0.00 \\
\hline \multicolumn{17}{|l|}{$\begin{array}{l}\text { V6: } \% 25-\mathrm{m} \text { shoreline } \\
\text { subsections containing }\end{array}$} \\
\hline potential perches & 40.62 & 5.66 & 38.75 & 4.75 & 30.31 & 2.73 & 37.19 & 4.21 & 39.69 & 3.58 & 33.75 & 2.58 & 35.47 & 3.32 & 37.97 & 3.07 \\
\hline SIV6 & 0.52 & 0.04 & 0.51 & 0.04 & 0.44 & 0.02 & 0.50 & 0.03 & 0.52 & 0.03 & 0.47 & 0.02 & 0.48 & 0.03 & 0.50 & 0.02 \\
\hline \multicolumn{17}{|l|}{$\begin{array}{l}\text { V7: distance from potential } \\
\text { perch to potential }\end{array}$} \\
\hline nesting bank (m) & 197.02 & 70.44 & 193.19 & 95.33 & 153.78 & 78.25 & 131.80 & 95.08 & 195.11 & 57.26 & 142.79 & 59.55 & 175.40 & 51.16 & 162.49 & 65.52 \\
\hline SIV7 & 0.94 & 0.02 & 0.93 & 0.03 & 0.95 & 0.03 & 0.96 & 0.03 & 0.93 & 0.02 & 0.95 & 0.02 & 0.94 & 0.02 & 0.94 & 0.02 \\
\hline \multicolumn{17}{|l|}{ Water component: } \\
\hline \multicolumn{17}{|c|}{$\mathrm{SIW}=(\operatorname{SIV} 2 \times \operatorname{SIV} 4 \times \operatorname{SIV} 5)^{1 / 3} *$} \\
\hline SIV3 & 0.33 & 0.01 & 0.34 & 0.01 & 0.43 & 0.01 & 0.44 & 0.01 & 0.34 & 0.01 & 0.44 & 0.01 & 0.38 & 0.01 & 0.39 & 0.02 \\
\hline
\end{tabular}


Appendix N. Continued.

\begin{tabular}{|c|c|c|c|c|c|c|c|c|c|c|c|c|c|c|c|c|}
\hline \multirow[b]{3}{*}{ HSI model and variables } & \multicolumn{8}{|c|}{ Treatment } & \multicolumn{4}{|c|}{ Channel } & \multicolumn{4}{|c|}{ Side } \\
\hline & \multicolumn{2}{|c|}{$\mathrm{BI}$} & \multicolumn{2}{|c|}{$\mathrm{BM}$} & \multicolumn{2}{|c|}{ M I } & \multicolumn{2}{|c|}{ MM } & \multicolumn{2}{|c|}{ Back } & \multicolumn{2}{|c|}{ Main } & \multicolumn{2}{|c|}{ Island } & \multicolumn{2}{|c|}{ Mainland } \\
\hline & $\bar{x}$ & SE & $\bar{x}$ & SE & $\bar{x}$ & SE & $\bar{x}$ & $\mathrm{SE}$ & $\bar{x}$ & $\mathrm{SE}$ & $\bar{x}$ & SE & $\bar{x}$ & $\mathrm{SE}$ & $\bar{x}$ & $\mathrm{SE}$ \\
\hline Cover component: & & & & & & & & & & & & & & & & \\
\hline $\mathrm{SIC}=\mathrm{SIV6}$ & 0.52 & 0.04 & 0.51 & 0.04 & 0.44 & 0.02 & 0.50 & 0.03 & 0.52 & 0.03 & 0.47 & 0.02 & 0.48 & 0.03 & 0.50 & 0.02 \\
\hline Reproduction component: & & & & & & & & & & & & & & & & \\
\hline $\mathrm{SIR}=\mathrm{SIV} 7$ & 0.94 & 0.02 & 0.93 & 0.03 & 0.95 & 0.03 & 0.96 & 0.03 & 0.93 & 0.02 & 0.95 & 0.02 & 0.94 & 0.02 & 0.94 & 0.02 \\
\hline HSI (lowest of 3 requisites) & 0.33 & 0.01 & 0.34 & 0.01 & 0.41 & 0.02 & 0.44 & 0.01 & 0.34 & 0.01 & 0.42 & 0.01 & 0.37 & 0.01 & 0.39 & 0.01 \\
\hline Great blue heron HSI & & & & & & & & & & & & & & & & \\
\hline $\begin{array}{l}\text { V1: distance between potential } \\
\text { nesting and potential }\end{array}$ & & & & & & & & & & & & & & & & \\
\hline foraging areas $(\mathrm{km})$ & $<1$ & $\mathrm{n} / \mathrm{a}$ & $<1$ & $\mathrm{n} / \mathrm{a}$ & $<1$ & $\mathrm{n} / \mathrm{a}$ & $<1$ & $\mathrm{n} / \mathrm{a}$ & $<1$ & $\mathrm{n} / \mathrm{a}$ & $<1$ & $\mathrm{n} / \mathrm{a}$ & $<1$ & $\mathrm{n} / \mathrm{a}$ & $<1$ & $\mathrm{n} / \mathrm{a}$ \\
\hline SIV1 & 1.00 & $\mathrm{n} / \mathrm{a}$ & 1.00 & $\mathrm{n} / \mathrm{a}$ & 1.00 & $\mathrm{n} / \mathrm{a}$ & 1.00 & $\mathrm{n} / \mathrm{a}$ & 1.00 & $\mathrm{n} / \mathrm{a}$ & 1.00 & $\mathrm{n} / \mathrm{a}$ & 1.00 & $\mathrm{n} / \mathrm{a}$ & 1.00 & $\mathrm{n} / \mathrm{a}$ \\
\hline $\begin{array}{l}\mathrm{V} 2 \text { : presence of potential } \\
\text { foraging area? }\end{array}$ & & & & & & & & & & & & & & & & \\
\hline $\begin{array}{l}\text { SIV2: frequency of area meeting } \\
\text { variable requirement }\end{array}$ & 1.00 & 0.00 & 1.00 & 0.00 & 1.00 & 0.00 & 1.00 & 0.00 & 1.00 & 0.00 & 1.00 & 0.00 & 1.00 & 0.00 & 1.00 & 0.00 \\
\hline $\begin{array}{l}\text { V3: disturbance-free zone } \\
\quad \geq 100 \mathrm{~m} \text { around potentia } \\
\text { foraging area? }\end{array}$ & & & & & & & & & & & & & & & & \\
\hline $\begin{array}{l}\text { SIV3: frequency of area meeting } \\
\text { variable requirement }\end{array}$ & 0.90 & 0.10 & 0.30 & 0.15 & 1.00 & 0.00 & 0.10 & 0.10 & 0.60 & 0.11 & 0.55 & 0.11 & 0.95 & 0.05 & 0.20 & 0.09 \\
\hline $\begin{array}{l}\text { V4: Presence of potential } \\
\text { nesting area } \leq 250 \mathrm{~m} \\
\text { from water? }\end{array}$ & & & & & & & & & & & & & & & & \\
\hline $\begin{array}{l}\text { SIV4: frequency of area meeting } \\
\text { variable requirement }\end{array}$ & 1.00 & 0.00 & 1.00 & 0.00 & 1.00 & 0.00 & 0.90 & 0.10 & 1.00 & 0.00 & 0.95 & 0.05 & 1.00 & 0.00 & 0.95 & 0.05 \\
\hline
\end{tabular}


Appendix N. Continued.

\begin{tabular}{|c|c|c|c|c|c|c|c|c|c|c|c|c|c|c|c|c|}
\hline \multirow[b]{3}{*}{ HSI model and variables } & \multicolumn{8}{|c|}{ Treatment } & \multicolumn{4}{|c|}{ Channel } & \multicolumn{4}{|c|}{ Side } \\
\hline & \multicolumn{2}{|c|}{ BI } & \multicolumn{2}{|c|}{$\mathrm{BM}$} & \multicolumn{2}{|c|}{ M I } & \multicolumn{2}{|c|}{ MM } & \multicolumn{2}{|c|}{ Back } & \multicolumn{2}{|c|}{ Main } & \multicolumn{2}{|c|}{ Island } & \multicolumn{2}{|c|}{ Mainland } \\
\hline & $\bar{x}$ & SE & $\bar{x}$ & $\mathrm{SE}$ & $\bar{x}$ & $\mathrm{SE}$ & $\bar{x}$ & SE & $\bar{x}$ & SE & $\bar{x}$ & SE & $\bar{x}$ & SE & $\bar{x}$ & $\mathrm{SE}$ \\
\hline $\begin{array}{l}\text { 150-m over water) around } \\
\text { potential nesting area? }\end{array}$ & & & & & & & & & & & & & & & & \\
\hline $\begin{array}{c}\text { SIV5: frequency of area meeting } \\
\text { variable requirement }\end{array}$ & 0.80 & 0.13 & 0.60 & 0.16 & 0.80 & 0.13 & 0.10 & 0.10 & 0.70 & 0.10 & 0.45 & 0.11 & 0.80 & 0.09 & 0.35 & 0.11 \\
\hline $\begin{array}{l}\text { V6: proximity of potential and } \\
\text { active nest sites }(\mathrm{km})\end{array}$ & 9.05 & 4.46 & 9.08 & 4.45 & 8.45 & 4.53 & 9.76 & 4.96 & 9.06 & 3.06 & 9.07 & 3.25 & 8.75 & 3.09 & 9.40 & 3.22 \\
\hline $\begin{array}{l}\text { SIV6 } \\
\text { Foraging component: }\end{array}$ & 0.74 & 0.08 & 0.74 & 0.08 & 0.74 & 0.08 & 0.66 & 0.11 & 0.74 & 0.06 & 0.70 & 0.07 & 0.74 & 0.06 & 0.70 & 0.07 \\
\hline $\begin{array}{l}\mathrm{FI}=\mathrm{SIV} 1 \times \mathrm{SIV} 2 \times \mathrm{SIV} 3 \\
\text { Reproduction component: } \\
\mathrm{RI}=(\mathrm{SIV} 1 \times \mathrm{SIV} 4 \times \mathrm{SIV} 5 \times\end{array}$ & 0.90 & 0.10 & 0.30 & 0.15 & 1.00 & 0.00 & 0.10 & 0.10 & 0.60 & 0.11 & 0.55 & 0.11 & 0.95 & 0.05 & 0.20 & 0.09 \\
\hline $\begin{array}{c}\mathrm{SIV} 6)^{1 / 2} \\
\mathrm{HSI}=(\mathrm{SIV} 1 \times \mathrm{SIV} 2 \times \mathrm{SIV} 3 \times\end{array}$ & 0.67 & 0.13 & 0.49 & 0.15 & 0.67 & 0.13 & 0.10 & 0.10 & 0.58 & 0.10 & 0.39 & 0.10 & 0.67 & 0.09 & 0.30 & 0.10 \\
\hline $\operatorname{SIV} 4 \times \operatorname{SIV} 5 \times \operatorname{SIV} 6)^{1 / 2}$ & 0.66 & 0.12 & 0.13 & 0.10 & 0.66 & 0.12 & 0.00 & 0.00 & 0.40 & 0.10 & 0.33 & 0.10 & 0.66 & 0.09 & 0.07 & 0.05 \\
\hline Mink HSI & & & & & & & & & & & & & & & & \\
\hline $\begin{array}{l}\text { V2: \% year with surface } \\
\text { water present }\end{array}$ & 100 & 0 & 100 & 0 & 100 & 0 & 100 & 0 & 100 & 0 & 100 & 0 & 100 & 0 & 100 & 0 \\
\hline SIV2 & 1.00 & 0.00 & 1.00 & 0.00 & 1.00 & 0.00 & 1.00 & 0.00 & 1.00 & 0.00 & 1.00 & 0.00 & 1.00 & 0.00 & 1.00 & 0.00 \\
\hline V4: \% woody canopy closure & & & & & & & & & & & & & & & & \\
\hline$\leq 100 \mathrm{~m}$ of water's edge & 59.34 & 5.17 & 39.65 & 4.19 & 50.69 & 5.41 & 35.38 & 5.65 & 49.49 & 3.95 & 43.03 & 4.19 & 55.02 & 3.77 & 37.51 & 3.46 \\
\hline SIV4 & 0.69 & 0.05 & 0.50 & 0.04 & 0.61 & 0.05 & 0.45 & 0.06 & 0.59 & 0.04 & 0.53 & 0.04 & 0.65 & 0.04 & 0.48 & 0.03 \\
\hline $\mathrm{HSI}=(\mathrm{SIV} 2 \times \mathrm{SIV} 4)^{1 / 3}$ & 0.88 & 0.02 & 0.79 & 0.02 & 0.84 & 0.02 & 0.76 & 0.03 & 0.83 & 0.02 & 0.80 & 0.02 & 0.86 & 0.02 & 0.77 & 0.02 \\
\hline $\begin{array}{l}\text { Muskrat HSI } \\
\text { V2: \% year with surface }\end{array}$ & & & & & & & & & & & & & & & & \\
\hline water present & 100 & 0 & 100 & 0 & 100 & 0 & 100 & 0 & 100 & 0 & 100 & 0 & 100 & 0 & 100 & 0 \\
\hline
\end{tabular}


Appendix N. Continued.

\begin{tabular}{|c|c|c|c|c|c|c|c|c|c|c|c|c|c|c|c|c|}
\hline \multirow[b]{3}{*}{ HSI model and variables } & \multicolumn{8}{|c|}{ Treatment } & \multicolumn{4}{|c|}{ Channel } & \multicolumn{4}{|c|}{ Side } \\
\hline & \multicolumn{2}{|c|}{$\mathrm{BI}$} & \multicolumn{2}{|c|}{$\mathrm{BM}$} & \multicolumn{2}{|c|}{ M I } & \multicolumn{2}{|c|}{ MM } & \multicolumn{2}{|c|}{ Back } & \multicolumn{2}{|c|}{ Main } & \multicolumn{2}{|c|}{ Island } & \multicolumn{2}{|c|}{ Mainland } \\
\hline & $\bar{x}$ & $\mathrm{SE}$ & $\bar{x}$ & SE & $\bar{x}$ & $\mathrm{SE}$ & $\bar{x}$ & $\mathrm{SE}$ & $\bar{x}$ & SE & $\bar{x}$ & $\mathrm{SE}$ & $\bar{x}$ & $\mathrm{SE}$ & $\bar{x}$ & $\mathrm{SE}$ \\
\hline SIV2 & 1.00 & 0.00 & 1.00 & 0.00 & 1.00 & 0.00 & 1.00 & 0.00 & 1.00 & 0.00 & 1.00 & 0.00 & 1.00 & 0.00 & 1.00 & 0.00 \\
\hline V3: \% stream gradient & 0.01 & 0.00 & 0.01 & 0.00 & 0.01 & 0.00 & 0.01 & 0.00 & 0.01 & 0.00 & 0.01 & 0.00 & 0.01 & 0.00 & 0.01 & 0.00 \\
\hline SIV3 & 1.00 & 0.00 & 1.00 & 0.00 & 1.00 & 0.00 & 1.00 & 0.00 & 1.00 & 0.00 & 1.00 & 0.00 & 1.00 & 0.00 & 1.00 & 0.00 \\
\hline \multicolumn{17}{|l|}{ V4: \% of channel with } \\
\hline surface water & 99.22 & 0.29 & 98.88 & 0.40 & 98.66 & 0.53 & 98.33 & 0.86 & 99.05 & 0.24 & 98.50 & 0.49 & 98.94 & 0.30 & 98.60 & 0.47 \\
\hline SIV4 & 0.99 & 0.00 & 0.99 & 0.00 & 0.99 & 0.01 & 0.98 & 0.01 & 0.99 & 0.00 & 0.98 & 0.01 & 0.99 & 0.00 & 0.99 & 0.01 \\
\hline \multicolumn{17}{|l|}{ V5: \% channel with persistent } \\
\hline SIV5 & 0.20 & 0.00 & 0.20 & 0.00 & 0.20 & 0.00 & 0.20 & 0.00 & 0.20 & 0.00 & 0.20 & 0.00 & 0.20 & 0.00 & 0.20 & 0.00 \\
\hline \multicolumn{17}{|l|}{ V6: \% herbaceous canopy cover } \\
\hline$\leq 10 \mathrm{~m}$ from water's edge & 92.04 & 2.13 & 78.32 & 4.63 & 73.96 & 4.45 & 67.67 & 4.79 & 85.18 & 2.94 & 70.82 & 3.26 & 83.00 & 3.17 & 73.00 & 3.46 \\
\hline SIV6 & 0.92 & 0.02 & 0.78 & 0.05 & 0.74 & 0.04 & 0.68 & 0.05 & 0.85 & 0.03 & 0.71 & 0.03 & 0.83 & 0.03 & 0.73 & 0.03 \\
\hline \multicolumn{17}{|l|}{ Cover requisite: } \\
\hline \multicolumn{17}{|l|}{$\mathrm{SIC}=\left([\mathrm{SIV} 2 \times \mathrm{SIV} 3 \times \mathrm{SIV} 4]^{1 / 3}+\right.$} \\
\hline SIV5)/2 & 0.60 & 0.00 & 0.60 & 0.00 & 0.60 & 0.00 & 0.60 & 0.00 & 0.60 & 0.00 & 0.60 & 0.00 & 0.60 & 0.00 & 0.60 & 0.00 \\
\hline \multicolumn{17}{|l|}{ Food requisite: } \\
\hline $\mathrm{SIF}=(\mathrm{SIV} 6+2[\mathrm{SIV} 5]) / 2$ & 0.66 & 0.01 & 0.59 & 0.02 & 0.57 & 0.02 & 0.54 & 0.02 & 0.63 & 0.01 & 0.55 & 0.02 & 0.62 & 0.02 & 0.56 & 0.02 \\
\hline HSI (lowest of 2 requisites) & 0.60 & 0.00 & 0.57 & 0.01 & 0.55 & 0.01 & 0.53 & 0.02 & 0.58 & 0.01 & 0.54 & 0.01 & 0.60 & 0.01 & 0.55 & 0.01 \\
\hline \multicolumn{17}{|l|}{ Snapping turtle HSI } \\
\hline \multicolumn{17}{|l|}{ V1: water temperature at mid- } \\
\hline depth during summer $\left({ }^{\circ} \mathrm{C}\right)$ & 27.57 & 0.21 & 27.52 & 0.23 & 27.56 & 0.22 & 27.73 & 0.23 & 27.54 & 0.15 & 27.65 & 0.15 & 27.57 & 0.15 & 27.62 & 0.16 \\
\hline SIV1 & 1.00 & 0.00 & 1.00 & 0.00 & 1.00 & 0.00 & 1.00 & 0.00 & 1.00 & 0.00 & 1.00 & 0.00 & 1.00 & 0.00 & 1.00 & 0.00 \\
\hline V2: current velocity $(\mathrm{cm} / \mathrm{sec})$ & 19.91 & 4.94 & 19.88 & 4.92 & 24.00 & 5.18 & 21.50 & 4.76 & 19.90 & 3.40 & 22.75 & 3.44 & 21.95 & 3.52 & 20.69 & 3.34 \\
\hline SIV2 & 0.70 & 0.07 & 0.70 & 0.07 & 0.66 & 0.08 & 0.68 & 0.07 & 0.70 & 0.05 & 0.67 & 0.05 & 0.68 & 0.05 & 0.69 & 0.05 \\
\hline
\end{tabular}


Appendix N. Continued.

\begin{tabular}{|c|c|c|c|c|c|c|c|c|c|c|c|c|c|c|c|c|}
\hline \multirow[b]{3}{*}{ HSI model and variables } & \multicolumn{8}{|c|}{ Treatment } & \multicolumn{4}{|c|}{ Channel } & \multicolumn{4}{|c|}{ Side } \\
\hline & \multicolumn{2}{|c|}{ BI } & \multicolumn{2}{|c|}{$\mathrm{BM}$} & \multicolumn{2}{|c|}{ M I } & \multicolumn{2}{|c|}{ MM } & \multicolumn{2}{|c|}{ Back } & \multicolumn{2}{|c|}{ Main } & \multicolumn{2}{|c|}{ Island } & \multicolumn{2}{|c|}{ Mainland } \\
\hline & $x$ & $\mathrm{SE}$ & $x$ & $\mathrm{SE}$ & $x$ & $\mathrm{SE}$ & $x$ & $\mathrm{SE}$ & $x$ & SE & $x$ & SE & $x$ & SE & $x$ & SE \\
\hline aquatic vegetation & 0.00 & 0.00 & 0.05 & 0.04 & 0.14 & 0.07 & 0.47 & 0.23 & 0.02 & 0.02 & 0.31 & 0.12 & 0.07 & 0.04 & 0.26 & 0.12 \\
\hline SIV3 & 0.00 & 0.00 & 0.00 & 0.00 & 0.00 & 0.00 & 0.00 & 0.00 & 0.00 & 0.00 & 0.00 & 0.00 & 0.00 & 0.00 & 0.00 & 0.00 \\
\hline \multicolumn{17}{|l|}{$\begin{array}{l}\text { V4: maximum water depth }> \\
\text { max. ice depth? }\end{array}$} \\
\hline $\begin{array}{c}\text { SIV4: frequency of area meeting } \\
\text { variable requirement }\end{array}$ & 1.00 & 0.00 & 1.00 & 0.00 & 1.00 & 0.00 & 1.00 & 0.00 & 1.00 & 0.00 & 1.00 & 0.00 & 1.00 & 0.00 & 1.00 & 0.00 \\
\hline V5: \% silt in substrate & 32.75 & 1.62 & 35.45 & 2.33 & 27.40 & 2.16 & 32.39 & 2.10 & 34.10 & 1.42 & 29.90 & 1.57 & 30.08 & 1.45 & 33.92 & 1.56 \\
\hline SIV5 & 0.33 & 0.02 & 0.35 & 0.02 & 0.28 & 0.02 & 0.32 & 0.02 & 0.34 & 0.01 & 0.30 & 0.02 & 0.30 & 0.01 & 0.34 & 0.02 \\
\hline V6: distance to small stream $(\mathrm{km})$ & 0.22 & 0.05 & 0.16 & 0.07 & 0.31 & 0.02 & 0.07 & 0.07 & 0.19 & 0.04 & 0.19 & 0.05 & 0.27 & 0.03 & 0.11 & 0.05 \\
\hline SIV6 & 0.98 & 0.00 & 0.98 & 0.01 & 0.97 & 0.00 & 0.99 & 0.01 & 0.98 & 0.00 & 0.98 & 0.01 & 0.97 & 0.00 & 0.99 & 0.01 \\
\hline \multicolumn{17}{|l|}{ V7: distance to permanent } \\
\hline water $(\mathrm{km})$ & 0.00 & 0.00 & 0.00 & 0.00 & 0.00 & 0.00 & 0.00 & 0.00 & 0.00 & 0.00 & 0.00 & 0.00 & 0.00 & 0.00 & 0.00 & 0.00 \\
\hline $\begin{array}{l}\text { SIV7 } \\
\text { Food component: }\end{array}$ & 1.00 & 0.00 & 1.00 & 0.00 & 1.00 & 0.00 & 1.00 & 0.00 & 1.00 & 0.00 & 1.00 & 0.00 & 1.00 & 0.00 & 1.00 & 0.00 \\
\hline $\begin{array}{l}\mathrm{SIF}=(\mathrm{V} 1 \times \mathrm{V} 2 \times \mathrm{V} 3)^{1 / 3} \\
\text { Winter cover component: }\end{array}$ & 0.00 & 0.00 & 0.02 & 0.02 & 0.04 & 0.02 & 0.09 & 0.03 & 0.01 & 0.01 & 0.07 & 0.02 & 0.02 & 0.01 & 0.06 & 0.02 \\
\hline $\begin{array}{l}\text { SIWC }=\text { SIV4 } \times \text { SIV5 } \\
\text { Reproduction component: }\end{array}$ & 0.33 & 0.02 & 0.35 & 0.02 & 0.28 & 0.02 & 0.32 & 0.02 & 0.34 & 0.01 & 0.30 & 0.02 & 0.30 & 0.01 & 0.34 & 0.02 \\
\hline $\mathrm{SIR}=\mathrm{SIV6}$ & 0.98 & 0.00 & 0.98 & 0.01 & 0.97 & 0.00 & 0.99 & 0.01 & 0.98 & 0.00 & 0.98 & 0.00 & 0.97 & 0.00 & 0.99 & 0.00 \\
\hline \multicolumn{17}{|l|}{$\mathrm{HSI}=(\mathrm{SIF} \times \mathrm{SIWC} \times \mathrm{SIR})^{1 / 3}$} \\
\hline$\times \mathrm{V} 7$ & 0.00 & 0.00 & 0.07 & 0.05 & 0.11 & 0.06 & 0.21 & 0.06 & 0.04 & 0.02 & 0.16 & 0.04 & 0.05 & 0.03 & 0.14 & 0.04 \\
\hline \multicolumn{17}{|l|}{ Wood duck HSI } \\
\hline $\begin{array}{l}\text { V4: \% water surface covered } \\
\text { by brood cover }\end{array}$ & 4.32 & 0.54 & 3.48 & 0.57 & 1.09 & 0.38 & 0.65 & 0.31 & 3.90 & 0.40 & 0.87 & 0.24 & 2.70 & 0.53 & 2.06 & 0.48 \\
\hline SIV4 & 0.09 & 0.01 & 0.06 & 0.01 & 0.02 & 0.01 & 0.02 & 0.01 & 0.07 & 0.01 & 0.02 & 0.00 & 0.05 & 0.01 & 0.04 & 0.01 \\
\hline
\end{tabular}


Appendix N. Continued.

\begin{tabular}{|c|c|c|c|c|c|c|c|c|c|c|c|c|c|c|c|c|}
\hline \multirow[b]{3}{*}{ HSI model and variables } & \multicolumn{8}{|c|}{ Treatment } & \multicolumn{4}{|c|}{ Channel } & \multicolumn{4}{|c|}{ Side } \\
\hline & \multicolumn{2}{|c|}{$\mathrm{BI}$} & \multicolumn{2}{|c|}{$\mathrm{BM}$} & \multicolumn{2}{|c|}{ M I } & \multicolumn{2}{|c|}{ MM } & \multicolumn{2}{|c|}{ Back } & \multicolumn{2}{|c|}{ Main } & \multicolumn{2}{|c|}{ Island } & \multicolumn{2}{|c|}{ Mainland } \\
\hline & $\bar{x}$ & $\mathrm{SE}$ & $\bar{x}$ & SE & $\bar{x}$ & SE & $\bar{x}$ & $\mathrm{SE}$ & $\bar{x}$ & $\mathrm{SE}$ & $\bar{x}$ & $\mathrm{SE}$ & $\bar{x}$ & $\mathrm{SE}$ & $\bar{x}$ & $\mathrm{SE}$ \\
\hline \multicolumn{17}{|c|}{ V5: \% water surface covered } \\
\hline by winter cover & 4.52 & 0.46 & 5.17 & 1.26 & 1.44 & 0.57 & 0.84 & 0.28 & 4.84 & 0.66 & 1.14 & 0.32 & 2.98 & 0.50 & 3.01 & 0.80 \\
\hline SIV5 & 0.09 & 0.01 & 0.10 & 0.02 & 0.03 & 0.01 & 0.02 & 0.01 & 0.10 & 0.01 & 0.02 & 0.01 & 0.06 & 0.01 & 0.06 & 0.02 \\
\hline \multicolumn{17}{|l|}{ Brood-rearing suitability: } \\
\hline SIV4 & 0.09 & 0.01 & 0.07 & 0.01 & 0.02 & 0.01 & 0.02 & 0.01 & 0.08 & 0.01 & 0.02 & 0.00 & 0.05 & 0.01 & 0.04 & 0.01 \\
\hline \multicolumn{17}{|l|}{ Winter habitat suitability: } \\
\hline SIV5 & 0.09 & 0.01 & 0.10 & 0.02 & 0.03 & 0.01 & 0.02 & 0.00 & 0.10 & 0.01 & 0.02 & 0.01 & 0.06 & 0.01 & 0.06 & 0.02 \\
\hline
\end{tabular}

${ }^{\text {a }}$ Belted kingfisher model and wood duck brood-rearing component could only be used with 8 islands due to model parameters.

${ }^{\mathrm{b}} \mathrm{BI}=$ back channel-island side, $\mathrm{BM}=$ back channel-mainland side, $\mathrm{MI}=$ main channel-island side, $\mathrm{MM}=$ main channel-mainland side. Treatments encompassed the length of the associated island and half the width of the associated back channel. Back channel $=$ $\mathrm{BI}$ and $\mathrm{BM}$ treatments, main channel $=\mathrm{BI}$ and $\mathrm{MM}$ treatments, island side $=\mathrm{BI}$ and $\mathrm{MI}$ treatments, mainland side $=\mathrm{BM}$ and $\mathrm{MM}$ treatments. 
Appendix O. Tests for channel, side, and treatment interactions with year, season, and/or period for measures of relative abundance of belted kingfishers, great blue herons, snapping turtles, and wood ducks, measured in accordance with habitat suitability index models, associated with 10 islands on the Ohio River, West Virginia, USA, 2001-2002. ${ }^{a}$

\begin{tabular}{|c|c|c|c|c|c|}
\hline Species & Variable $^{\mathrm{b}}$ & Source $^{c}$ & $F$ & $\mathrm{df}$ & $P$ \\
\hline \multirow[t]{12}{*}{ Belted kingfisher $^{\mathrm{d}}$} & \multirow[t]{6}{*}{ Total density } & Channel $\times$ year & 1.17 & 1,28 & 0.289 \\
\hline & & Side $\times$ year & 1.61 & 1,28 & 0.214 \\
\hline & & Treatment $\times$ year & 1.34 & 3,28 & 0.282 \\
\hline & & Channel $\times$ season & 5.68 & 1,60 & 0.020 \\
\hline & & Side $\times$ season & 0.21 & 1,60 & 0.648 \\
\hline & & Treatment $\times$ season & 2.25 & 3,60 & 0.092 \\
\hline & \multirow[t]{6}{*}{ Total frequency } & Channel $\times$ year & 0.19 & 1,28 & 0.665 \\
\hline & & Side $\times$ year & 2.93 & 1,28 & 0.098 \\
\hline & & Treatment $\times$ year & 2.80 & 3,28 & 0.058 \\
\hline & & Channel $\times$ season & 4.96 & 1,60 & $\mathbf{0 . 0 3 0}$ \\
\hline & & Side $\times$ season & 0.02 & 1,60 & 0.879 \\
\hline & & Treatment $\times$ season & 2.14 & 3,60 & 0.105 \\
\hline \multirow[t]{12}{*}{ Great blue heron } & \multirow[t]{6}{*}{ Total density } & Channel $\times$ year & 0.43 & 1,36 & 0.517 \\
\hline & & Side $\times$ year & 1.43 & 1,36 & 0.239 \\
\hline & & Treatment $\times$ year & 1.50 & 3,36 & 0.230 \\
\hline & & Channel $\times$ season & 0.22 & 1,76 & 0.641 \\
\hline & & Side $\times$ season & 0.01 & 1,76 & 0.911 \\
\hline & & Treatment $\times$ season & 0.12 & 3,76 & 0.948 \\
\hline & \multirow[t]{6}{*}{ Total frequency } & Channel $\times$ year & 0.43 & 1,36 & 0.517 \\
\hline & & Side $\times$ year & 1.43 & 1,36 & 0.239 \\
\hline & & Treatment $\times$ year & 1.43 & 3,36 & 0.251 \\
\hline & & Channel $\times$ season & 1.34 & 1,76 & 0.231 \\
\hline & & Side $\times$ season & 0.40 & 1,76 & 0.530 \\
\hline & & Treatment $\times$ season & 0.59 & 3,76 & 0.623 \\
\hline \multirow[t]{9}{*}{ Snapping turtle } & \multirow[t]{3}{*}{ Summer abundance } & Channel $\times$ period & 2.09 & 2,72 & 0.131 \\
\hline & & Side $\times$ period & 0.24 & 2,72 & 0.786 \\
\hline & & Treatment $\times$ period & 0.86 & 6,72 & 0.531 \\
\hline & \multirow[t]{3}{*}{ Fall abundance } & Channel $\times$ period & 0.62 & 1,36 & 0.438 \\
\hline & & Side $\times$ period & 0.01 & 1,36 & 0.911 \\
\hline & & Treatment $\times$ period & 0.41 & 3,36 & 0.743 \\
\hline & \multirow[t]{3}{*}{ Total abundance } & Channel $\times$ season & 1.13 & 1,36 & 0.296 \\
\hline & & Side $\times$ season & 0.66 & 1,36 & 0.421 \\
\hline & & Treatment $\times$ season & 1.34 & 3,36 & 0.275 \\
\hline
\end{tabular}


Appendix O. Continued

\begin{tabular}{llllll}
\hline Species & Variable & Source & $F$ & df & $P$ \\
\hline Wood duck & Summer density & Channel $\times$ year & 0.53 & 1,28 & 0.472 \\
& & Side $\times$ year & 0.38 & 1,28 & 0.542 \\
& Summer frequency & Treatment $\times$ year & 0.32 & 3,28 & 0.809 \\
& Channel $\times$ year & 0.88 & 1,28 & 0.356 \\
& Fall density & Side $\times$ year & 0.13 & 1,28 & 0.718 \\
& & Treatment $\times$ year & 0.34 & 3,28 & 0.797 \\
& & Channel $\times$ year & 3.97 & 1,36 & 0.054 \\
& Fall frequency & Side $\times$ year & 0.00 & 1,36 & 0.965 \\
& Treatment $\times$ year & 1.38 & 3,36 & 0.265 \\
& Channel $\times$ year & 4.05 & 1,36 & 0.052 \\
& & Side $\times$ year & 0.02 & 1,36 & 0.895 \\
& & Treatment $\times$ year & 1.38 & 3,36 & 0.265 \\
\hline
\end{tabular}

${ }^{a}$ Belted kingfisher and wood duck summer relative abundance was only estimated for 8 islands.

${ }^{\mathrm{b}}$ Density $=$ no. birds $/$ ha; frequency $=$ no. birds $/ \mathrm{km}$; snapping turtle abundance $=$ no. captured/trap-night.

${ }^{c}$ Channels encompassed an island and mainland shoreline and extended into the river from each shoreline a distance equal to half the width of the associated back channel. Sides encompassed a back channel and main channel shoreline and extended into the river from each shoreline a distance equal to half the width of the associated back channel. Treatments encompassed 1 shoreline and extended into the river a distance equal to one-half the width of the associated back channel.

${ }^{\mathrm{d}}$ Belted kingfisher and great blue heron abundance was estimated for spring and summer.

${ }^{\mathrm{e}}$ Snapping turtle summer relative abundance measured during 3 survey periods and fall abundance measured during 2 survey periods. 